\title{
Narrative space and spatial transference in Jacob and Wilhelm Grimm's fairy tales
}

Kujundžić, Nada

Doctoral thesis / Disertacija

2020

Degree Grantor / Ustanova koja je dodijelila akademski / stručni stupanj: University of Zagreb, University of Zagreb, Faculty of Humanities and Social Sciences / Sveučilište u Zagrebu, Filozofski fakultet

https://doi.org/10.17234/diss.2020.7469

Permanent link / Trajna poveznica: https://urn.nsk.hr/urn:nbn:hr:131:390050

Rights / Prava: In copyright/Zaštićeno autorskim pravom.

Download date / Datum preuzimanja: 2023-04-26

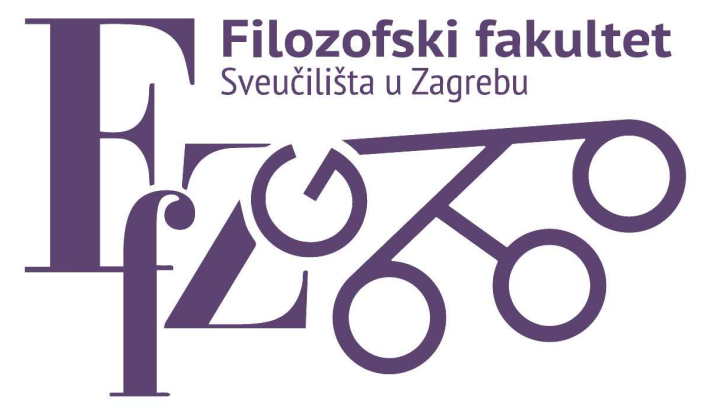

Repository / Repozitorij:

ODRAZ - open repository of the University of Zagreb Faculty of Humanities and Social Sciences
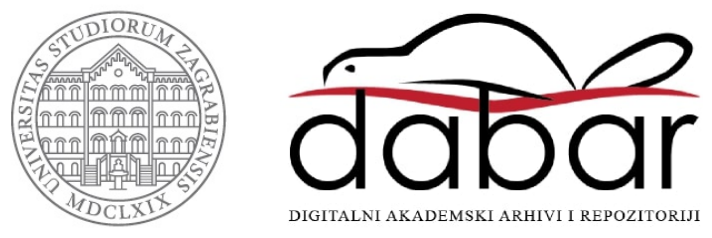


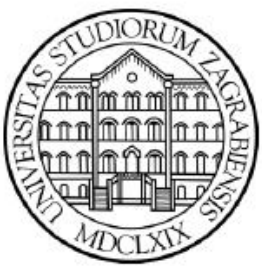

Sveučilište u Zagrebu

Filozofski fakultet

\section{UNIVERSITY
ONIJ OF TURKU}

Sveučilište u Turkuu

Fakultet humanističkih znanosti

Nada Kujundžić

\section{NARRATIVE SPACE AND SPATIAL TRANSFERENCE IN JACOB AND WILHELM GRIMM'S FAIRY TALES}

MEĐUNARODNI DVOJNI DOKTORAT ZNANOSTI

Zagreb, 2020. 


\section{University of Zagreb}

Faculty of Humanities and Social Sciences

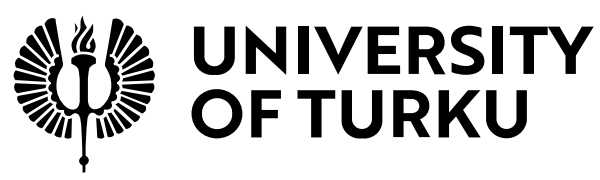

Faculty of Humanities

Nada Kujundžić

\section{NARRATIVE SPACE AND SPATIAL TRANSFERENCE IN JACOB AND WILHELM GRIMM'S FAIRY TALES}

INTERNATIONAL DUAL DOCTORATE

Supervisors:

Professor Emeritus Pekka Hakamies Associate Professor Marijana Hameršak 


\section{University of Zagreb}

Filozofski fakultet

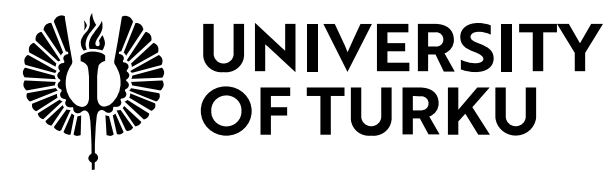

Fakultet humanističkih znanosti

Nada Kujundžić

\title{
PRIPOVJEDNI PROSTOR I PROSTORNO PREMJEŠTANJE U BAJKAMA JACOBA I WILHELMA GRIMMA
}

\author{
MEĐUNARODNI DVOJNI DOKTORAT ZNANOSTI
}

\author{
Mentori: \\ profesor emeritus Pekka Hakamies \\ doc.dr.sc. Marijana Hameršak
}

Zagreb, 2020. 


\section{About the Supervisors}

\section{Supervisors:}

Professor Emeritus Pekka Hakamies, University of Turku, Turku, Finland

Associate Professor Marijana Hameršak, Institute of Ethnology and Folklore Research, Zagreb, Croatia

\section{Thesis advisors (co-supervisors) at the University of Turku:}

Professor Emerita Liisa Steinby, University of Turku, Turku, Finland

Professor Karin Kukkonen, University of Oslo, Oslo, Norway

Pekka Hakamies is Professor Emeritus of Folkloristics at the University of Turku. He worked at the University of Joensuu for 22 years and moved to his professor post at the University of Turku in 2006. He has been the Editor-in-Chief of the series Folklore Fellows Communications (FFC) and the FF Network from 2010 until 2018. His research interests include the modernisation of folk culture in the Soviet Karelia, ethnic identity on the Karelian-Finnish border area, heritage, Kalevala poetry, and paremiology. He also studies the told memories and experiences of Soviet citizens as they arrived in the regions and homes deserted by Finns in the areas of Karelia ceded to the Soviet Union as a result of the Second World War (edited volume Moving in the USSR: Western anomalies and Northern wilderness, 2005). With Anneli Honko he edited Theoretical Milestones. Selected Writings of Lauri Honko (2013) and with Anne Heimo Folklore in the Digital Age (2019). He has held numerous positions of trust at universities and within scientific societies.

Marijana Hameršak is a senior Research Associate at the Institute of Ethnology and Folklore Research in Zagreb and a titular Assistant Professor at the University of Zagreb. She graduated in Comparative Literature and General Linguistics from the Faculty of Humanities and Social Sciences in Zagreb in 2000, and earned her PhD at the same Faculty in 2008 with the thesis Formations of Childhood and Transformations of Fairy Tales in Croatian Children's Literature. Her research interests include the history and anthropology of childhood and children's literature, material and institutional aspects of literature, popular culture, folklore, folklore studies, and migration. She is one of the editors of the Nova etnografija (New ethnography) book series of the Institute of Ethnology and Folklore Research. She is the author of Pričalice: o povijesti djetinjstva i bajke (2011) and co-author of Uvod u dječju književnost (with Dubravka Zima, 2015). With Suzana Marjanić she edited Folkloristička čitanka (2010), and with Iva Pleše and Ana-Marija Vukušić Proizvodnja baštine: kritičke studije o nematerijalnoj kulturi (2013). With Emina Bužinkić she edited Formation and Disintegration of the Balkan Refugee Corridor (Zagreb - Munich, 2018). 
Karin Kukkonen is Professor of Comparative Literature at the University of Oslo. She is the convenor of the research and education initiative Literature, Cognition and Emotions (LCE), an interdisciplinary hub that brings together literary studies, linguistics, psychology, and neurosciences in a new conversation about literature. In 2019, she was awarded the first University of Oslo's Young Researchers Prize. Her research interests include narratology, poetics, eighteenth-century literature, comics and graphic novels, and cognitive literary study. She is the author of Studying Comics and Graphic Novels (Wiley-Blackwell, 2013), Contemporary Comics Storytelling (University of Nebraska Press, 2013), A Prehistory of Cognitive Poetics: Neoclassicism and the Novel (Oxford University Press, 2017), 4E Cognition and Eighteenth-Century Fiction: How the Novel Found its Feet (Oxford University Press, 2019), and Probability Designs: Literature and Predictive Processing (Oxford University Press, 2020).

Liisa Steinby is Professor Emerita of Comparative Literature at the University of Turku. Her research interests include aspects of modernity in the novel from the eighteenth century to the present. Her single-authored book publications include Der postindividualistische Roman (1994), Nietzsche als Roman. Über die Sinnkonstituierung in Thomas Manns Doktor Faustus (1996), Erzählstruktur und Bildungsroman. Wielands Geschichte des Agathon, Goethes Wilhelm Meisters Lehrjahre (2004), Wilhelm Meisters Lehrjahre und die Entstehung des modernen Zeitbewusstseins (2005), Kundera and Modernity (2013), and Imagining the Absolute. Myth in the Modern Novel (in press). She has also published twenty-one edited volumes - including Bakhtin and His Others (with Tintti Klapuri, 2013) and Narrative Concepts in the Study of Eighteenth-Century Literature (with Aino Mäkikalli, 2017) - in addition to more than one hundred scholarly articles. She was the Vice-President of the International Herder Society from 2017-2018 and its President from 2019-2020. 


\section{Sažetak}

U doktorskom se radu istražuju pripovjedni prostor i prostorno premještanje u bajkama objavljenim u zbirci Kinder- und Hausmärchen (Djetinje i kućne bajke, 1857.) Jacoba i Wilhelma Grimma. Korpus istraživanja, koji obuhvaća 215 žanrovski raznolikih tekstova, podijeljen je na dva djela: primarni korpus, koji obuhvaća bajke, te sekundarni korpus, koji obuhvaća priče o životinjama, poučne priče, etiološke priče, (usmene) pripovijetke, formulne priče, predaje, legende, vjerske priče i šaljive priče. Sekundarni korpus omogućava poredbenu analizu bajke i drugih kratkih proznih žanrova.

Tema pripovjednog prostora u bajkama podzastupljena je u znanstvenoj literaturi, gdje se prostor bajke uglavnom tretira kao pasivna pozadina zbivanja koja ni na koji način ne utječe na njihov razvoj, te postoji naprosto jer se radnja mora negdje odvijati. Ovakav stav donekle je razumljiv s obzirom na dugotrajan manjak interesa za prostorne teme u humanističkim $i$ društvenim znanstvenima (prije tzv. prostornog obrata), kao i slabo definirane prostorne parametre koje nudi sama bajke. Naime, u svom tradicionalnom obliku, bajka kao jezično ekonomičan žanr uglavnom izbjegava sve što izravno ne pridonosi razvoju radnje, poput opisa likova ili okoline. Postojeća istraživanja uglavnom naglašavaju apstraktnu, slabo definiranu prirodu prostora bajke ili su usmjerena na njegova simbolička i metaforička značenja. U središtu zanimanja stoga nije prostor kao takav, već kao izvor informacija o značenju priče ili drugim pripovjednim elementima (npr. likovima).

Za razliku od dosadašnjih istraživanja, ovaj doktorski rad pripovjedni prostor bajke razumije kao materijalnu, trodimenzionalnu okolinu te autonoman i nužan pripovjedni element koji je značajan sam po sebi. U središtu istraživanja su struktura prostora bajke, njegova prezentacija ( $\mathrm{tj}$. pripovjedne i jezične strategije kojima se prenose informacije o prostoru) i opće odlike. Osim pripovjednim prostorom, doktorski se rad bavi i prostornim premještanjem koje je glavni preduvjet za ostvarivanje kontakta između ljudskog protagonista i čarobnog, što se pak smatra ključnom osobinom žanra bajke. Nadalje, premještanje omogućava povezivanje pojedinih lokaliteta u širu prostornu mrežu.

Istraživanje je smješteno unutar teorijskog okvira tzv. istraživanja ili studija o bajkama (fairy-tale studies), te metodološko-analitičkog okvira naratologije. Pritom ne slijedi jedinstveni pravac unutar istraživanja bajke, već sistematizira znanje nastalo unutar različitih teorijskih orijentacija. Od osobite važnosti za ovo istraživanje radovi su Maxa Lüthija i Alfreda Messerlija (istraživanja o bajkama), te Marie-Laure Ryan i Katrin Dennerlein (naratologija).

Analiza strukture pripovjednog prostora oslanja se na model koji je ponudila Marie-Laure Ryan, sastavljen od pet prostornih jedinica: prostornog okvira, smjestišta (eng. setting), prostora priče, pripovjednog svijeta i pripovjednog svemira. Primjena ovog modela na analizu bajke otkrila je slojevitost njenog pripovjednog prostora i složenost procesa njegove konstrukcije, koji se odvija kroz kontinuirano pregovaranja između čitatelja i teksta. Kako bi ovaj opći model prilagodilo istraživanju bajke, istraživanje ga je dopunilo novom kategorijom domene, koja obuhvaća prostore u kojima je na snazi određeni sustav prirodnih zakona. Bajka se sastoji od dvije domene: ne-čarobne (,realistične“) i čarobne. Samo po sebi, postojanje dvaju kvalitativno oprečnih domena nije jedinstveno bajci, već obilježava i druge kratke prozne žanrove, poput legende i vjerske pripovijetke. U doktorskom se radu stoga tvrdi da 
osobitost žanra bajke proizlazi iz interakcije među domenama i načinima prelaska granice koja ih dijeli. Točnije, spomenuta se granica može prijeći s obje strane, ali samo privremeno (mobilni lik do kraja priče mora se vratiti u svoju ishodišnu domenu) i pod određenim uvjetima. Iako se uvjeti za prelaženje granice razlikuju za ljudske i čudesne likove, zajednička im je pretpostavka uspostavljanje kontakta s ciljnom domenom, najčešće otjelovljenom u liku čuvara ulaza. Kako bi ušli u čarobnu domenu, ljudski likovi moraju dokazati da posjeduju pozitivne kvalitete poput suosjećanja, hrabrosti ili velikodušnosti, ili da su upoznati s automatskim pravilima priče. U čarobnu se domenu pripuštaju izgubljeni ili zlostavljani likovi. Čarobno može i navabiti ljudske likove uz pomoć predmeta, životinja, te vizualnih ili auditivnih signala kako bi im naštetilo ili zatražilo njihovu pomoć. Zloćudno čarobno u nečarobnu domenu može nasilno prodrijeti ili manipulacijom iznuditi poziv od strane ljudskog lika. Dobroćudno čarobno u ne-čarobnu domenu stupa na poziv ljudskog lika. Taj poziv često je nehotičan, a javlja se u obliku verbalnih (izravan poziv, dopuštenje, vjenčani zavjet, želja, čarolije i druge verbalne formule, poziv u pomoć) i neverbalnih zaziva (plakanje, negativne misli, odustajanje, geste i ponašanje koji odaju očaj).

Analiza sekundarnog korpusa istraživanja kroz prizmu prostora potaknula je reviziju njegove početne klasifikacije. Naime, uočeno je da pojedine skupine priča (konkretno, poučne, etiološke i šaljive priče) nemaju stabilnu prostornu strukturu, te da se broj i kvaliteta njihovih domena mijenjaju. Za njih je, stoga, zaključeno da nisu samostalni žanrovi već potkategorije ili modusi drugih žanrova, koje odlikuje stabilan broj domena. Osim toga, rezultati istraživanja potaknuli su i reviziju početne definicije žanra bajke, koji se (uzimajući prostor u obzir), može opisati kao pripovjedni žanr koji prikazuje dvije jasno razdvojene i kvalitativno oprečne domene: ne-čarobnu i čarobnu. U toku priče, te domene moraju stupiti u (privremeni) kontakt, koji je uvjetovan prostornim premještanjem, poglavito prelaženjem granice među domenama. Ta se granica može prijeći s obje strane, ali samo privremeno i pod određenim uvjetima. Istraživanje ovime upućuje na potencijal pripovjednog prostora kao relevantne kategorije klasifikacije žanrova.

Istraživanje nadalje pokazuje da manjak eksplicitnih informacija o prostoru u bajkama ne treba tumačiti kao znak njegove nevažnosti, već kao odraz ekonomičnosti žanra. Drugim riječima, činjenica da bajka rijetko izravno i detaljno progovara o prostoru ne znači da njen prostor nije važan, već naprosto da je - zbog jezične ekonomičnosti - razvila alternativne strategije kojima na izravne (imenovanje, izravni opis) i neizravne (opisno pripovijedanje, uputnice na likove, predmete i materijale) načine otkriva detalje vlastitog pripovjednog prostora. $\mathrm{Na}$ koncu, istraživanje opisuje prostor bajke kao dinamičan pripovjedni element kreiran kroz brojne odnose između likova, predmeta, događaja i drugih prostora. U tom smislu, prostor nije, kao što sugeriraju starije definicije, tek spremnik za likove i pozadina događanja, već sudionik složenih odnosa kao i važan faktor klasifikacije žanrova.

Ključne riječi: bajka, pripovjedni prostor, prostorno premještanje, Kinder- und Hausmärchen, Jacob i Wilhelm Grimm, naratologija, žanr 


\begin{abstract}
Owing to the lack of concrete information provided by the narratives and the genre's unspecified setting, narrative space in fairy tales has been largely overlooked or dismissed as an inactive background for the action. Research which has considered this topic typically views it in terms of its symbolic potential, studying space in order to learn about other narrative elements (e.g. characters) or the implied meanings of the texts. This dissertation views narrative space as a concrete, material aspect of the narrative which is significant in itself.
\end{abstract}

The main research question posed in the dissertation is: what do fairy tales tell us about narrative space and what does narrative space tell us about fairy tales? The main aim of the dissertation is therefore twofold: first, it examines how narrative space is structured in fairy tales and how the fairy tale conveys space-related information; second, it asks whether there is anything about the traits and structure of fairy-tale space that can be seen as genre-specific, i.e. that sets the fairy tale apart from other short prose narrative genres. The research is based on a textual analysis of the English translation of Jacob and Wilhelm Grimm's collection Kinder- und Hausmärchen (Children's and Household Tales, 1857). While its primary focus is on fairy tales, the dissertation also considers other genres included in the collection (animal tales, legends, religious tales, etc.). The research combines the knowledge produced within fairy-tale scholarship (folklore and literature studies) with the methodological tools of narratology.

By considering narrative space and spatial transference, the dissertation aims to prompt a reconsideration of the fairy-tale genre and its definitions. One of its key findings is therefore a revised definition of the fairy tale as a genre which encompasses two domains - the magical and the non-magical - separated by a firm boundary, which must be crossed in the course of the story. What sets this interdomain boundary apart is the fact that it can be crossed from both sides, but only temporarily and only if certain conditions are met. The examination of genres through the prism of the domain has led to a reconsideration of our initial genre classification and prompted the conclusion that aetiological tales, Schwank tales, and didactic tales, which were initially listed as independent genres, are modes (subgenres) rather than genres. The thesis also shows that fairy-tale space is dynamic and relational, and that the lack of explicit spatial information should not be seen as an indication of the insignificance of space, but rather an expression of the genre's stylistic parsimony. Although the findings are based on the study of the Grimms' fairy tales, the dissertation aims to provide an analytical framework that is applicable to other fairy-tale corpora.

Keywords: fairy tale, narrative space, spatial transference, Jacob and Wilhelm Grimm, Kinder- und Hausmärchen, narratology, genre 


\section{Acknowledgements}

Like the fairy-tale protagonist whose success relies on the aid of various magical helpers and donors, I too owe the completion of the long and arduous journey from initial idea to finished dissertation to a number of patient and wonderfully supportive travel companions. I am grateful for this opportunity to acknowledge their contribution to this thesis.

First and foremost, my sincerest gratitude goes to my excellent supervisors: Marijana Hameršak (Institute for Ethnology and Folklore Research in Zagreb), Pekka Hakamies (University of Turku), Liisa Steinby (University of Turku), and Karin Kukkonen (University of Oslo). They have been very patient, encouraging and understanding, and most generous with their time and expertise. I can honestly say that I would not be where I am without them. Marijana convinced me that this was an interesting and fruitful research topic, and, with her personal integrity and professionalism, has served as an inspirational role model. I am especially grateful for all the pep talks and her boundless, infectious enthusiasm. Pekka took an interest in my work when I first came to Turku as an exchange student, inspiring me to broaden my research horizons. He has always been an encouraging and stimulating interlocutor, as well as a calming presence. Liisa's high professional standards and insistence on excellence continue to be a source of inspiration, as well as a reminder that one can (and should) always do better. Karin gave me a much-needed boost at a time when I was running out of steam and generously shared her extensive knowledge of all things fairy tale. She helped me tune my time management skills and, through her insightful comments, brought out the best in my texts. All three of them read more versions of this manuscript than I would care to admit, offering expert advice and helping me make sense of all the ideas brewing in my head. Their support extend beyond the professional as they also provided much guidance and encouragement when I was having doubts about my project.

I am grateful and honoured to have had my manuscript pre-examined by three prominent experts in their respective fields: Professor Emeritus Ulf Palmenfelt, Professor Daniel Sävborg, and Professor Lana Molvarec. Their incisive and detailed feedback was essential for the finalisation of the manuscript. I would also like to thank Professor Sävborg for agreeing to serve as my esteemed opponent.

For the financial support which enabled me to travel in order to conduct research and write my thesis at the University of Turku and the University of Alberta, I am indebted to the Erasmus Foundation (the Join-EU SEE Program) and the Wirth Institute for Austrian and Central European Studies.

In the course of my doctoral studies, I have benefited from the advice and professional support from a number of experts. I am especially indebted to Sapu Ato, who showed enthusiasm for this project when it was little more than a bunch of ideas, Andreas Stuhlmann, Elena Pnevmonidou, and Jack Zipes. Dean Duda and Stipe Grgas, who acted as preexaminers at the defence of my thesis topic, deserve special mention for their kind guidance and insightful questions which helped me develop my initial ideas in new directions. My 
sincere gratitude goes to Anne Heimo, whose friendship, understanding, and practical assistance were integral for finalising the manuscript and preparing for the defence. I would also like to thank Clive Tolley and Osmo Pekonen, who provided invaluable assistance with the linguistic aspects of the thesis (proofreading and translating, respectively).

Over the years, participation in numerous conferences, workshops, and seminars enabled me to engage in enlightening discussions with fellow researchers. I am indebted to all the organisers and participants in these events who provided insightful feedback on my work. The research seminars at the University of Turku's Department of Folkloristics and the Department of Comparative Literature were especially vital platforms for exchanging ideas and learning from my colleagues. For their support and friendship, I thank Arbnora Dushi, Pasi Enges, Nikica Gilić, Jelena Gligorijević, Kirsi Hänninen, Tuomas Hovi, Kaarina Koski, Jaana Kouri, Merja Leppälahti, Suzana Marjanić, Smiljana Narančić Kovač, Sirpa Ollila, and the lively team from SIEF's Young Scholars Working Group (especially Arnika and Mathilde). I thank all the students at the Faculty of Teacher Education in Zagreb I have had the pleasure and privilege of teaching, especially those attending the course on fairy tales and adaptations. Their enthusiasm for the topic, diligence, and creativity demonstrated in their own adaptations reminded me why I fell in love with fairy tales in the first place.

Finally, my most heartfelt gratitude goes to my wonderful family. I thank my parents, who have instilled in me a love of literature and intellectual curiosity which prompted me to pursue a career in academia. Together with my siblings, they never stopped believing in me and supporting me, even when the obstacles seemed insurmountable. Finally, I thank my husband and number one fan, Matúš, who has always been enthusiastic about my work and made sure I stayed focused on the important things. Lúbim t'a, miláčik, you are more than I ever could have wished for: a model scholar whose shining example is a constant source of inspiration; a critical reviewer who has patiently (re)read early drafts of each chapter, improving them with sound criticism; a supportive friend who believes in me even when I don't; a loving partner who is always there for me. Thank you for everything - ty a Matilda ste moje všetko. 


\section{Table of Contents}

Table of Contents ......................................................................... 1

1 Introduction ............................................................................ 4

Key concepts..................................................................... 7

Research corpus .................................................................... 12

Research aims and methods ............................................. 14

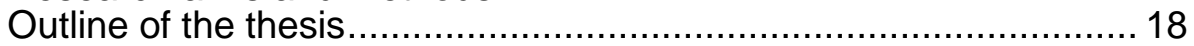

2 Narrative Space in Fairy Tales: Overview of Literature .......21

Space in fairy-tale scholarship................................................ 22

Space as symbol of the unconscious: psychoanalytical approaches ........................................................ 23

Space as connective and structural principle: formal approaches .......................................................... 26

Space as the background for action: literary approaches ........ 30

Literary and extra-literary landscapes: socio-historical approaches ........................................................ 34

Natural spaces: feminist approaches.................................... 39

(Non-)normative spaces: queer/trans and disability studies.... 42

Space in focus..................................................................... 46

The present research ................................................................ 51

3 Spatial Structure in Fairy Tales ..........................................56

Studying space in narratives.................................................. 57

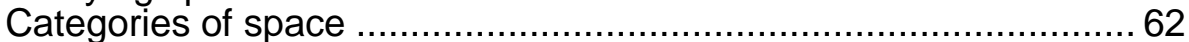

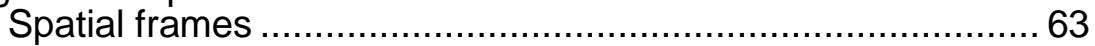

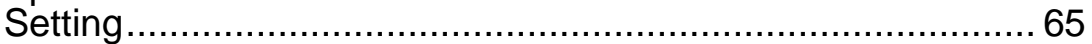

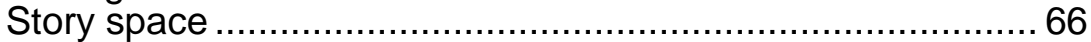

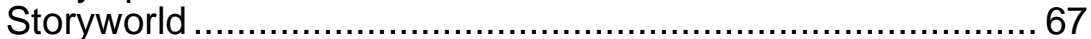

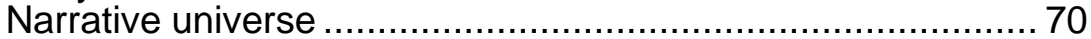

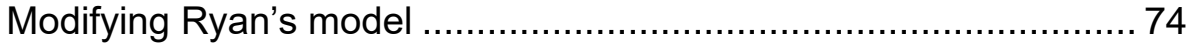

A note on terminology ................................................. 77

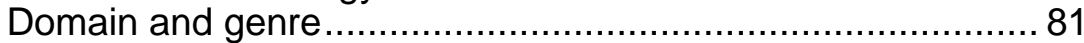

The dyadic world of the fairy tale ..................................... 87

4 Crossing the Boundary between the Non-magical and the Magical...........................................................................92

Moving from the non-magical into the magical $(\mathrm{N} \rightarrow \mathrm{M}) \ldots \ldots \ldots \ldots \ldots . . . . . . . .93$

Testing the protagonist ..................................................... 94 
Vulnerable protagonist ....................................................... 97

Luring the non-magical into the magical ............................... 98

Moving from the magical into the non-magical $(\mathrm{M} \rightarrow \mathrm{N}) \ldots \ldots \ldots \ldots \ldots . . . . . .101$

Verbal summons ............................................................ 101

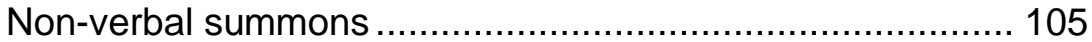

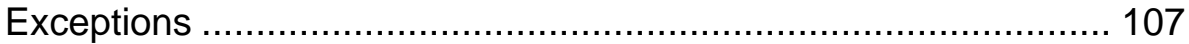

Fairy tale vs. other dyadic genres............................................ 111

Dyadic genres of the KHM ............................................. 111

Crossing the boundary from both sides .............................. 117

Temporary crossing .................................................... 120

Meeting special requirements ........................................ 122

Space as the basis for genre definitions and classifications . 124

5 Presenting Space.............................................................. 128

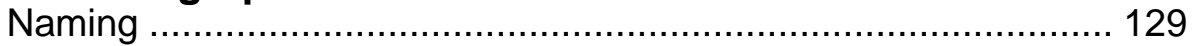

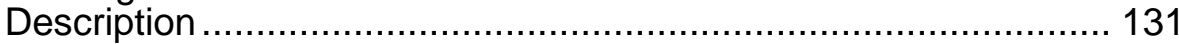

Descriptised narration, narratised description....................... 137

Characters as indirect means of establishing space...................... 139

Character identity and actions .......................................... 140

Focalisation, verbalisation, cognition ................................ 142

Objects and materials as indirect means of establishing space ..... 145

Spatial dimensions and distances .......................................... 149

Itinerary and magical means of transportation........................ 150

Units of distance and temporal expressions ....................... 152

Repetition and audio-visual signals ................................... 154

Conveying information about space in the fairy tale .................... 156

6 Qualities of Fairy-Tale Space............................................... 160

Unspecified and unlocalised................................................ 161

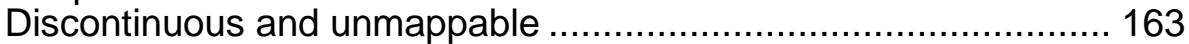

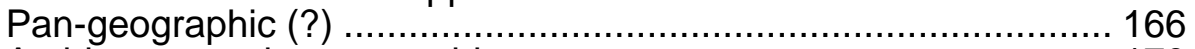

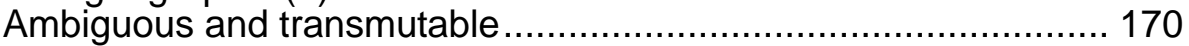

Dynamic and relational.......................................................... 175

Interrelationship between space and characters .................. 176

Space and identity transformation ................................... 179

7 Conclusion ........................................................................... 188

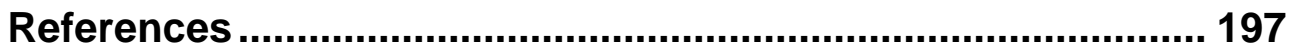

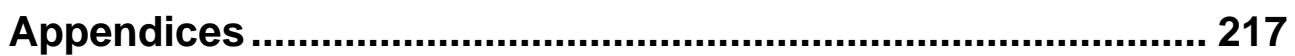

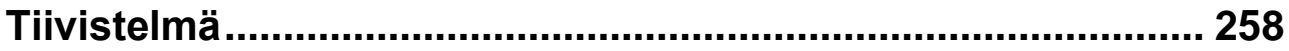




\section{Figures}

Figure 1. The storyworld of "The Frog King" ...................................... 70

Figure 2. The narrative universe of "The Frog King" ............................ 72

Figure 3. Fairy-tale domains............................................................ 89

Figure 4. Illustrations of "Mother Holle"............................................. 165

Figure 5. Spatial transference and identity transformations in "All

Fur" ........................................................................... 183

Figure 6. Spatial transference and identity transformations in "The Virgin Mary's Child" .............................................................. 184 


\section{Introduction}

Many of the fairy tales published by Jacob and Wilhelm Grimm follow a similar pattern, which includes the main character leaving home and moving across a number of new, often unfamiliar spaces. Some of the best-known examples include Snow White fleeing from her royal home into the woods, where she finds shelter in the cottage of a band of dwarfs; Cinderella leaving her stepmother's house to go to the royal ball, where she catches the prince's eye; the infant Rapunzel being taken from her parents and locked away in a tall tower with no doors; Hansel and Gretel being abandoned in the depths of the forest, where they stumble upon a scrumptiouslooking cottage made of bread and decorated with cake.

Whether they are fleeing from danger like Snow White, sneaking out to go to a party like Cinderella, or leaving home in search of adventure or a lost fiancée like so many heroes and heroines of the Grimms' tales, fairy-tale characters - most notably, protagonists - are highly mobile. Starting with their initial departure from home, the characters constantly move between and within individual spaces. Thus, the entire plot of the fairy tale can be described as a series of movements or spatial transferences. Furthermore, abandoning the familiar, domestic space and going into the unknown or, more generally, crossing the boundary between "home" and "nonhome", creates an opportunity for the protagonist to come into contact with the magical, which is one of the defining features of the genre. This movement within and between fairy-tale spaces (i.e. spatial transference) along with space itself constitute the main research focus of this doctoral thesis.

By focusing on space, the present research challenges dominant views of this heretofore mostly overlooked aspect of the fairy-tale narrative, primarily the notion that space in fairy tales is a mere backdrop for the action which in no way influences it and exists simply because the story has to take place somewhere. Such a position is perhaps unsurprising considering the long-lasting disregard of space within the humanities and social sciences on the one hand, and the lack of (explicit) spacerelated information in fairy tales on the other. The view of space as a static backdrop, frame or "container of a virtually neutral kind, designed simply to receive whatever is poured into it" without affecting it in any way (Lefebvre 1991[1974]: 94), was for a long time widely accepted within the various disciplines within the humanities and 
social sciences. Simply put, space was seen as the "negative opposite" of time, and associated with stability and materiality, as well as a lack of change and, indirectly, a lack of progress (Massey 2005: 28, 117). Furthermore, space may have been "taken for granted" because of its accessibility (both in the physical and experiential sense) and the high degree of control humans have over it, thus appearing less intellectually stimulating and challenging than the elusive and mysterious time (Casey 1997: ix). On the other hand, this same close link between humans and space in which they are inevitably "immersed" and which they "could not do without" (ibid.) eventually became a strong argument for the study of space in the wake of the so-called spatial turn (Soja 1989: 39), a (paradigmatic) ${ }^{1}$ shift of focus within the humanities and social sciences during the 1970s and 1980s, which is primarily characterised by the "rediscovery of space as a central category" (Bachmann-Medick 2016[2015]: 212).

In studies of narratives - broadly defined as the use of signs to convey a story or the representation of a sequence of events that is being narrated (Ryan 2017: 518) the privileged position of time (and, subsequently, the subordinate position of space) was reinforced by the understanding of narration as a tracing of temporal changes, of sequences of events that unfold in time, perhaps most influentially stated in Gotthold Ephraim Lessing's Laocoon (1887[1766]). The essay characterises painting (and visual arts in general) as a spatial art, because it represents objects which stand next to each other in space. In contrast, poetry (and literature in general) is understood as a temporal art which can "express only objects which succeed each other, or whose parts succeed each other, in time" (Lessing 1887[1766]: 91). Painting thus focuses on spatial proximity, while poetry strives to represent events in their temporal sequence. The central significance of time in literature as explicated by Lessing seemed "too evident to be seriously interrogated" (Buchholz \& Jahn 2005: 551), as did the presumed background function of space, long seen as a "more or less optional" (Herman 2002: 267), or even "merely incidental" (Liddell 1947: 111) narrative element, which does not exist independently of the plot and characters. Gerald Prince's observation that while it is "practically impossible to narrate a series of events without establishing a set of temporal or temporally bound relationships between narration and narrated", a story can be completely devoid of spatial references (1982: 32), is illustrative of such views.

In addition to the long-standing disregard of space in literature, another possible reason for the lack of scholarly interest in fairy-tale space is the scarcity of space-

For a discussion on whether the spatial turn can be considered a paradigm-changing shift, see the works of Edward Soja (1989), who calls it "one of the most important philosophical and intellectual developments of the twentieth century" (1996: 196), and Doris Bachmann-Medick (2016[2015]), who denies it the status of paradigm because it does not promote a novel way of thinking, merely new methods and approaches. 
related information provided by the narratives and what appears to be a favouring of temporal aspects of narrative over spatial ones. Thus, even though the genre is often described as both "timeless" and "spaceless" (Thomas 1986: 126), meaning that it is not rooted in any concrete (historical) time or (geographical) space, the explicit narrative emphasis on time featured in standard opening formulae such as "Once there was" or "Once upon a time" prompted scholars such as Wilhelm Nicolaisen to conclude that the narrative gives priority to time, as it poses the question "when the world of the folktale was but not where" (1988: 360, emphases added). Furthermore, as an action-oriented genre, the traditional ${ }^{2}$ fairy tale typically disregards anything that does not immediately move the plot forward, such as descriptions of characters or settings (cf. Lüthi 1986[1947]). As a result, individual locations are often unspecified or identified via generic labels: thus, the story may be set in $a$ kingdom, which the hero will leave to travel to $a$ far-away land and probably get lost in $a$ forest on the way. Scholarly texts that consider spatial features of the fairy tale typically focus on this lack of specific traits, listing "spatial indeterminacy" (Propp 1968[1928]: 151) and "anonymity of the location" (Robert \& Powell 1969: 53) among the staples of the genre. The fact that the fairy tale is set in an "unreal world without definite locality" (Thompson 1977[1946]: 8) is often seen as evidence of the genre's supposed timelessness and universality (Franz 1996[1970]: 39). ${ }^{3}$

The significance and even presence of space in traditional fairy tales is therefore easily overlooked; after all, the narratives themselves rarely seem to draw attention to it. Furthermore, the pervasiveness of the romantic perception of fairy tales as taking place in an almost mythical spatio-temporal environment which is simultaneously everywhere and nowhere, always and never (Jolles 1969[1930]: 244), obscures the view of space as a significant element of the fairy-tale narrative. Content with the knowledge that fairy tales take place "once upon a time" in a land "far far away", we rarely consider the specifics of "far far away". Accepting the parsimonious language as a staple of the genre, we do not expect elaborate descriptions of the characters or the environments they inhabit, forgetting about the plethora of indirect ways in which stories can convey spatial information, such as references to characters, whose (social) identities often indicate the spaces they

2 The term "traditional fairy tale" is here used as a synonym for what Elizabeth W. Harries terms the compact or Grimm/Perrault model, which mimics oral tradition and is characterised by narrative and linguistic simplicity (2003[2001]: 16). Harries juxtaposes this with the so-called complex model, which encompasses lengthy, often embedded narratives, written in ornate language, and is explicitly evocative of the written fairy-tale tradition (ibid.).

3 In fact, as André Jolles notes, giving it specific geographical coordinates would presumably diminish much of the fairy tale's aesthetic impact and appeal (1969[1930]: 244). 
inhabit. Challenging the long-standing disregard of fairy-tale space, this doctoral thesis calls for a re-evaluation of its background status and overall significance for the genre, as well as a reconsideration of the oft-repeated claims about the near absence and near irrelevance of spatial information in fairy tales. It does so by asking what fairy tales tell us about space and what space can tell us about fairy tales.

\section{Key concepts}

The key concepts of the present research are the fairy tale, space, and spatial transference. The first among these - the fairy tale - is notoriously difficult to pinpoint. While there seems to be a basic (almost intuitive) understanding of what fairy tales are, possibly because most readers encounter them at an early age (Nodelman \& Reimer 2003[1992]: 302), scholars across disciplines have been struggling to reach a consensus on how precisely to delineate and describe this generic category. To modify Roger Sale's claim about children's literature: everyone knows what a fairy tale is until they are asked to define it (1978: 1). As a result, it remains "an ill-defined construction lacking any sort of stable definition" (Smith 2007: 2). The problem stems from a variety of sources, including a degree of terminological confusion, derived in part from the inconsistent use and wide, indiscriminate application of the (literal) English translation of the French term for the genre, the extraordinary diversity and mutability of the genre, and lack of scholarly consensus.

The English term "fairy tale" (alternatively spelled "fairytale" or "fairy-tale") is a translation of the French term conte de fées (literally, a tale about fairies) coined by Marie-Catherine d'Aulnoy and first used in the title of her collection Les contes des fées (1697), ${ }^{4}$ published in English as Tales of the Fairies in 1699 (Palmer \& Palmer 1974: 228). While D'Aulnoy's term is well suited to the seventeenth- and eighteenth-century French fairy-tale tradition, which abounds in fairies (see, for instance, Harries 2003[2001]; Seifert 1996), it is not necessarily as good a fit for other narrative traditions in which these magical creatures may be less prominent. While the reference to fairies was retained in the English translation of the term, the "fairy" in "fairy tale" gradually became dissociated from a specific creature with magical properties and associated with Fäerie or the magical realm in general (Tolkien 1965[1947]: 16). Ultimately, the term was used to designate any (folk) tale featuring non-realistic elements (Jones 2002[1995]: 9).

Some scholars prefer the German term Märchen to the fairy tale (e.g. Thompson 1977[1946]), despite its much wider field of reference. Namely, Märchen designates

4 D'Aulnoy is also the author of the first French literary fairy tale, "The Island of Happiness", inserted in her 1690 novel The History of Hypolite, the Count of Duglas. 
a story in the widest possible sense, a (short) fictional prose narrative (Bascom 1965: 4). As such, it presents an umbrella term for individual short prose narrative genres, the names of which are usually generated by adding a descriptive prefix to the basic term Märchen, for instance Zaubermarchën (tales of magic, magic tales), Tiermärchen (animal tales), Schwankmärchen (humorous or jocular tales), etc. (Bošković-Stulli 2006[1997]: 21). Scholars approach the relationship between the Märchen and the fairy tale in one of the following ways: some not only use the former term in its broader meaning implied by the German original, but also retain its German form (e.g. Thompson 1977). Others translate it as "folktale" and use it exclusively in reference to oral tradition, i.e. in contrast to literary tales (Kunstmärchen). Used in that sense, the term Märchen is equated with the Volksmärchen or oral tale. Similarly, some use the term fairy tale very broadly, to designate any fictional (short) prose narrative that contains non-realistic elements, thus ascribing the original meaning of the Märchen to the fairy tale. In contrast, scholars such as Jack Zipes (2002[2000]a: xv) associate the term fairy tale only with the literary tradition, opting for different terms such as wonder or magic tale (English equivalents of the German Zauber- or Wundermärchen) when referring to the oral tradition. While acknowledging its shortcomings, the present research follows the dominant trend within fairy-tale scholarship and uses the term fairy tale.

The problems pertaining to the delineation of the fairy-tale genre are not generated by terminological infelicities alone. On the contrary, these may be viewed merely as a reflection of the immense diversity and dynamic nature of this protean genre. To paraphrase Adam Roberts's observations on science fiction, definitions of the fairy tale are "manifold not because critics and historians of the form are confused, or can't agree on key points", but because the fairy tale itself is a "wideranging, multivalent and endlessly cross-fertilising cultural idiom" (2006[2000]: 2). In fact, its range and multivalence are such that one could easily conclude that there is, in fact, "no such thing as the fairy tale", only "hundreds of thousands of fairy tales", which "have been defined in so many different ways that it boggles the mind to think that they can be categorized as a genre" (Zipes 2002[2000]a: xv, original emphasis). To be sure, this type of mutability is by no means unique to the fairy tale and may, given the immense variety of individual manifestations of a given genre across cultures, languages, and literary periods, be seen as a staple of genre as such (Cohen 1991: 105; see also Koski, Frog, \& Savolainen 2016). While the popular understanding of the fairy tale largely draws on what might be termed the "traditional" or "classical" model, primarily associated with the tales of Charles Perrault and the Brothers Grimm (Harries 2003[2001]: 16), the fairy tale has proved to be a veritable "shape shifter" (Greenhill \& Matrix 2010: 3), appearing in innumerable cultural and linguistic variants, and media incarnations. As a result, the 
term has expanded beyond oral and written texts ${ }^{5}$ to include (among others) "operas, songs, poems, advertisements, cartoons, comic strips, graphic novels, comic books, ballets, dramas, radio plays, and hypertexts on television and the Internet" (Zipes 2011: 8).

The lack of consensus on what fairy tales are also stems from the fact that individual scholars and theoretical approaches have different starting points for their musings on the genre, such as plot (Bottigheimer 2009), structure (Propp 1968[1928]), style (Lüthi 1986[1947]), or the presence of specific themes and motifs, such as fantasy elements, successful resolution of problems (Jones 2002[1995]: xiv), or wondrous transformations (Zipes 2002[2000]a: xvii). For Vladimir Propp, the fairy tale is a story which proceeds from initial lack to its successful liquidation, following a common underlying structure (1968[1928]: 92); for Max Lüthi (1986[1947]), it is a world-encompassing adventure story characterised by a unique style which has the ability to absorb any motif and treatment of the "otherworldly" as part of everyday experience; for Ruth Bottigheimer, the genre-specific element is the narrative trajectory which depicts the social rise of a human protagonist, manifested as either the regaining of a lost royal position (so-called restoration tales) or ascent up the social ladder (rise fairy tales), and made possible by magical assistance (2009: 9-12). ${ }^{6}$ Various themes and motifs such as wondrous transformations, impossible tasks, character tests, wish fulfilment, and various family- and marriage-related issues such as sibling rivalry, the relationship between (step-)parents and children, and the quest for a spouse are often listed among the typical features of the genre, as is the proverbial happily ever after (cf. Warner 2014). Zipes sees the happy ending as a staple of the oral wonder tale, linking unhappy endings exclusively to the literary fairy tale (2002[2000]a: xvii). Others have proposed special terms to designate fairy tales which end badly for the protagonist, such as unhappy, antipodal (Tatar 2003[1987]: 179), or even anti-fairy tales (Jolles 1969[1930]: 242), thus underscoring their difference from "typical" representatives of the genre.

5 Despite its connotations of literacy/print, the term "text" is here used quite broadly in reference to both oral and written literature (cf. Stock 1996[1990]), and even more generally to refer to any cultural item with sufficient coherence to be seen as a single object (e.g. a television show or film; Gray \& Lotz 2012: 27).

6 Bottigheimer's (2009) classification of fairy-tale plots bears much similarity to the one proposed by Satu Apo (1995), which is based on the comparison between the social positions the protagonist occupies at the beginning and end of the narrative. Apo's plot type A - comparable to Bottigheimer's concept of rise fairy tales - refers to narratives in which the protagonists improve their initial situation (climb the social ladder) by achieving positive goals, while plot type B (reminiscent of restoration tales) centres around protagonists who are faced with a crisis which they successfully overcome in the course of the narrative (1995: 24-25). 
Since it ultimately aims to expand the discussion on the fairy-tale genre to include spatial issues, the present research begins with a working definition of the fairy tale, which builds on the observations of Propp (1968[1928]), Lüthi (1986[1947]), and Bottigheimer (2009). The ontological homogeneity (or, to use Lüthi's term, one-dimensionality; 1986[1947]: 10) wherein the otherworldly is not perceived as "other" but as part of everyday life is understood as the defining feature of the genre. The fairy tale is therefore defined as a prose narrative in which the "realistic" (human) and the "magical" come into contact, but their encounter fails to provoke surprise, fear, or disbelief. Furthermore, in most fairy tales, magical intervention brings about positive results for the human protagonist - typically manifested as social rise and material security - even if those results are ultimately invalidated.

The next concept that is central to the present research - space - is characterised by similar terminological issues. Namely, existing scholarship on narratives uses a variety of space-related terminology which is often inconsistently used and seldom clearly defined (Hones 2014: 8). Depending on the author, theoretical orientation, school of thought, and/or time of writing, different terms (with varying degrees of overlap in meaning) appear in discussions of spatial aspects of narratives, including setting (Wellek \& Warren 1956[1948]), environment (Rimmon-Kenan 1983), landscape (Liddell 1947), place (Lutwack 1984), and space (Baak 1983; Ryan, Foote, \& Azaryahu 2016). "Space" in particular is ascribed a wide range of meanings, "from the individual object described in a narrative to the cosmic order in which the story takes place" (Ryan et al. 2016: 23). Space-related terminological discussions extend across disciplines within the humanities and social sciences. A prominent place belongs to discussions about space and place, typically differentiated with regards to movement and the presence/absence of emotional bonds. Simply put, place is defined as static, ${ }^{7}$ a "point of rest" (Tuan 2008[1977]: 161), which can be transformed into space (understood as "a practiced place"; Certeau 1988[1980]: 117, original emphasis) with the introduction of a dynamic component. A reverse process wherein an abstract and undifferentiated space becomes place can be accomplished by establishing emotional bonds with a space or endowing it with special meanings and values (Tuan 2008[1977]: 6).

The present research uses the term narrative space (used interchangeably with space) to designate the physical, three-dimensional environment in which the characters live and move (Buchholz \& Jahn 2005: 552; Dennerlein 2009: 71). It

7 In his discussion of the terms "space", "place", and "setting", Joshua Parker (2012/14) claims that if place is indeed defined as static (as opposed to the dynamic space), it is incompatible with the dynamic (and temporal) narrative. In other words, the static nature of place precludes the possibility of narrative place (Parker 2012/14: 80). 
builds on the following assumptions about space in narrative: it is an essential rather than optional component of narrative; it is interconnected with time; and it is more than a sum of individual locations. While not discussed separately, the term place is used to designate a specific location or point in space (cf. Zoran 1984: 323). As used in this dissertation, the term space excludes metaphorical and symbolic meanings of the word, and is limited to the physical environments that constitute the world of the story along with that world as a whole. It should also be noted that this dissertation only deals with space in the text (spaces explicitly depicted or implied by the narrative) and not the space of the text (physical space occupied by the text), or the space of narration.

The third key concept of the present research, spatial transference, is broadly defined as any type of movement within a given space or between individual spaces (Rosowski 1987: 89). The act of transference typically encompasses three elements: the point of departure (initial or starting point), the physical movement itself, and the point of arrival (destination or end point; Duda 1998: 54). An additional, optional element is the return, the presence/absence of which introduces the possibility of classifying transference as either one-way (unidirectional, linear) or two-way (bidirectional, return, or circular). Further classifications can be made based on volition (voluntary or forced transference; Šundalić 2010: 94), modes of transport, or the spatial axis along which the transference unfolds (horizontal, vertical, or both).

Studies of spatial mobility in literature - including fairy tales (cf. Leeuwen 2007) - tend to focus on the journey as its most common manifestation (see, among others, Biggs \& Blum 2019; Duda 2012; Schönle 2000). While the term is often broadly defined as any type of movement which includes a change of location, narrower definitions insist that travelling involves boundary-crossing and covering large distances (Šundalić 2010: 103). Susan Rosowski, for instance, associates travelling with movement through space, but not movement within space (1987: 89). Furthermore, travelling is commonly distinguished from other, highly automatised and pragmatic types of transference such as going to work or to the store, through its link to exploration, discovery, and knowledge acquisition (Molvarec 2010: 289290). ${ }^{8}$ As "an attempt to engage with the unknown and the different, to expose oneself to other ways of life and cultures" (Crang 2005: 35), travelling implies willing and active participation on the part of the mobile subject. It also implies a certain degree of "security and privilege to move about in relatively unconstrained ways" (Clifford 1997: 34), which suggests voluntary mobility, usually motivated by

8 The cognitive and educational aspect of travelling is perhaps best exemplified in the concept of the Grand Tour, a trip around Europe undertaken by young (English) men of considerable means and high social standing, as a sort of educational rite of passage during the seventeenth and eighteenth centuries (see, for instance, Black 2003[1992]). 
clearly defined goals. Viewed from that perspective, the term does not encompass the different types of forced transference or transference without a clear motivation or destination featured in our research corpus (see below), such as flight, wandering, banishment, or abduction. Since the scope of the present research goes beyond mere travelling, I use the broader term spatial transference. What is more, the said term also foregrounds both movement (transference) and its spatial component.

\section{Research corpus}

This research on space and spatial transference in fairy tales is based on a textual analysis of the tales - primarily fairy tales ${ }^{9}$ - published in Jacob and Wilhelm Grimm's seminal collection Children's and Household Tales (Kinder- und Hausmärchen, 1812/15-1857, abbr. KHM). The choice of the Grimms' collection as a starting point for an exploration of a heretofore largely overlooked aspect of the fairy-tale genre seems justified given the book's unique popularity and canonical status (Heinz Rölleke, for instance, identifies the KHM as the most translated and frequently published German book; 1988[1986]: 109), as well as the influence of the Grimms' model on the popular perception of the fairy tale (Lindahl 2018: 12). André Jolles, for instance, claims that the Grimms' tales provide a blueprint for the genre, so that we identify the stories that correspond to the KHM texts as fairy tales, going so far as to propose a circular definition of the fairy tale as a type of tale collected by the Grimms and published in their collection (1969[1930]: 219). Kay Turner and Pauline Greenhill express a similar view when they claim that the Grimms' texts, "arguably more than those of other compilers and scholars", defined both the scholarly and popular understanding of the fairy tale (2012a: 1). Furthermore, a significant portion of scholarship on the fairy tale encompasses examinations of the KHM, with many new approaches such as queer/trans (Turner \& Greenhill 2012b) or disability studies (Schmiesing 2014) taking it as a starting point for their explorations of the genre.

The research corpus encompasses texts published in the seventh, so-called large, edition (Große Ausgabe) of the Grimms' collection published in 1857, the last to appear during the brothers' lifetimes; although not the main research focus, the six

Although the term Märchen might seem more appropriate for the study of German fairy tales, this research opts for the term fairy tale, since it understands Märchen as a supracategory which encompasses generically diverse short prose narratives (considering the generic diversity of the KHM, the Grimms also seem to have this meaning in mind in the title of their collection). Furthermore, based on their influence and canonical status, this research views the Grimms' tales not as representative of the German fairy-tale tradition but as prototypical examples of the fairy tale in general. 
preceding "large" editions of the KHM (1812/1815-1850) ${ }^{10}$ are also consulted. Since the comparisons of the different editions of the KHM are not at the centre of this research, and since the complex history of the Grimms' collection has been expertly outlined elsewhere, ${ }^{11}$ there is no need to repeat it here. The present research acknowledges the importance of the numerous historical, social, ideological, political, cultural, and literary factors that shaped the KHM; however, it does not consider this extra-textual framework and is instead based on textual analysis. The research presented in this thesis is based on the English translation of the final edition of the Grimms' collection (trans. Jack Zipes; Grimm 2003[1857]). While the German original is consulted throughout (Grimm 1857a; 1857b), ${ }^{12}$ I refrain from making indepth observations on its linguistic aspects since I am not an expert on German and the research is based on a literary, rather than linguistic analysis of the KHM.

The main limitation of this research stems from its exclusive focus on the text, which comes at the expense of extra-literary elements such as the social, cultural, historical, literary, and geographical framework in which the analysed corpus was created. Therefore, future research on both the KHM and other fairy-tale corpora might consider how these extra-literary elements - especially the physical and cultural geography of individual narrating communities - shape the representation of narrative space. Another limitation of the research is the lack of consistent focus on the different editions of the KHM. While acknowledging that each tale within its corpus was produced by a multitude of voices and shaped over a course of several decades, the research focuses on (the English translation of) the final edition of the KHM. A more comprehensive comparison of the different editions of the collection is therefore warranted.

Widely defined, the research corpus encompasses all the texts included in the final edition of the KHM, regardless of genre (a total of 215 generically diverse texts; see Appendix 1). While the primary focus is on fairy tales, the generic diversity of the research corpus is seen as an advantage, as it allows for comparisons between

10 The six "large" editions of the KHM were published in 1812 and 1815 (2 volumes of the first edition $), 1819$ ( $\left.2^{\text {nd }} \mathrm{edn}\right), 1837$ ( $\left.3^{\text {rd }} \mathrm{edn}\right), 1840$ ( $\left.4^{\text {th }} \mathrm{edn}\right), 1843\left(5^{\text {th }} \mathrm{edn}\right)$, and 1850 $\left(6^{\text {th }}\right.$ edn $)$. The present research will consult their online editions, available at the Deutsches Textarchiv (http://www.deutschestextarchiv.de/).

11 For more insight into the editorial and publication history of the KHM, the reader is primarily referred to the works of Heinz Rölleke (1985; 1993; 2000), who published critical editions of the KHM and the Ölenberg manuscript, as well as the writings of, among others, Ruth Bottigheimer (1987; 2009: 27-52), Charles Briggs (1993), Linda Dégh (1979), Siegfried Neumann (1993), Maria Tatar (2003[1987]), Hans-Jörg Uther (2013[2008]: 459-499), and Jack Zipes (2002[1988]; 2006[1983]: 59-79; 2015).

12 Both volumes of the 1857 edition of the KHM are available at the Deutsches Textarchiv (http://www.deutschestextarchiv.de/book/show/grimm_maerchen01_1857;

http://www.deutschestextarchiv.de/book/show/grimm_maerchen02_1857). 
fairy tales and other genres. Using the previously outlined working definition of the genre, 96 KHM texts were identified as fairy tales and included in the primary research corpus. The remainder of the texts, constituting the secondary research corpus, was divided into the following genre categories: animal tales, didactic tales, aetiological tales, folk tales, formula tales, legends, religious tales, and humorous or Schwank tales (the individual genres will be discussed in more detail in Chapters 3 and 4). While they are not at the centre of this research, the inclusion of non-fairytale KHM genres into the corpus allows for a comparative analysis that sheds new light on the fairy-tale genre and its (possibly unique) spatial features. Establishing whether or not there is anything genre-specific about the narrative space of the fairy tale - particularly its structure - should promote our understanding of the genre, enabling us to modify our working definition of the fairy tale so as to include narrative space.

In order to draw overarching conclusions about space and spatial transference in the Grimms' fairy tales, the present research works with a large number of texts. This certainly has its advantages as the numerous examples of different fairy tales featured in the KHM provide a more comprehensive insight into the genre. Moreover, the inclusion of genres other than fairy tales allows for comparisons that may reveal whether space and spatial transference bear any genre-specific traits. However, this approach has its drawbacks as well. Not only is it difficult to strike a balance between overarching conclusions based on multiple texts and in-depth discussions of individual examples, but the large number of tales considered also means that many of them will only be used as illustrations rather than studied in detail. Instead of providing a comprehensive analysis of every single narrative included in the corpus, this research will support its more general observations and conclusions with more detailed readings of representative examples. Admittedly, there is some arbitrariness and personal preference in the choice of tales that are discussed more extensively. One could argue that many other texts could have been chosen in place of those featured in the analytical sections; however, this interchangeability of examples may also be seen as a reflection of the wider applicability of the main findings of this dissertation.

\section{Research aims and methods}

The present research examines space and spatial transference in the fairy tales published in the final edition of Jacob and Wilhelm Grimm's Children's and Household Tales. Specifically, it focuses on the following aspects of fairy-tale space: its structure, presentation (i.e. the means of conveying spatial information), and general traits. Special attention is given to spatial transference as a means of connecting individual spaces into a wider spatial network, and enabling the 
interaction between the human and the magical, which this research treats as one of the key features of the fairy-tale genre.

This research aims to challenge the heretofore largely insufficient scholarly interest in space in fairy tales (for notable exceptions, see Chapter 2) by acknowledging its importance and arguing for its active role in the fairy-tale narrative. Following recent re-examinations of traditional views of space as a passive background against which the plot unfolds, this research considers space as a dynamic narrative element which is not only shaped by the characters and plot but, in turn, shapes them. Rather than a mere "container in which the entities are found and the events take place" (Abbott 2008[2002]: 20), space is defined through complex sets of relations which produce its different qualities and functions within individual tales (see, for instance, Foucault 1986[1984]; Lefebvre 1991[1974]). Traditional definitions of the genre often list the abstract, unspecified quality of space and overall lack of spatial information as a common feature of the fairy tale, which might explain the absence of systematic scholarly inquiry into this issue. Instead of interpreting what seems to be the scarcity of spatial information as a sign of the irrelevance of space for the genre, this research asks whether the traditional fairy tale really does withhold spatial information, as is often assumed. Furthermore, it proposes that the apparent lack of spatial information is primarily a lack of explicit, direct spatial information, which, what is more, should not be seen as an indicator of the insignificance of space, but rather as a manifestation of the genre's economical style and focus on action. In other words, the economical and action-driven fairy tale does not disregard spatial information, but simply relies on different, indirect means to convey them.

This thesis aims to explore the structure of narrative space, its textual and linguistic presentation, and its qualities by using narratological textual analysis. In doing so, it poses two central research questions: what do fairy tales tell us about space and what can space tell us about fairy tales as a genre. Existing definitions of the genre either overlook space entirely or only mention its abstract quality -i.e. the fact that the stories seem to be set nowhere in particular - as characteristic of the fairy tale. However, this lack of concrete localisation is far from being unique to the fairy tale. On the contrary, most of the KHM tales are set in an unspecified environment: animal tales such as "The Mouse, the Bird, and the Sausage" (KHM 23, ATU 85), religious tales such as "The Star Coins" (KHM 153, ATU 779H*), or Schwank tales such as "Freddy and Katy" (KHM 59, ATU 1387, 1541, 1291, 1653) all share the unlocalised quality of the fairy tale, as their characters also live in $a$ house or $a$ village, which they occasionally leave to go into $a$ forest or $a$ field. The present research therefore looks beyond the unspecified spatio-temporal setting, which is a feature of a number of short prose narrative genres, in an attempt to determine whether there is anything about the structure, presentation, or qualities of 
space that is unique to the fairy tale. To that end, the research scope expands beyond fairy tales and encompasses other genres featured in the KHM, which are examined through the lens of space and spatial transference, and compared to the fairy tale. By assuming such a comparative approach, this research aims to expand existing considerations of the fairy tale by highlighting narrative space as a possible criterion for distinguishing between the different (short) prose narrative genres.

The present research is situated within the theoretical framework of fairy-tale studies, which is complemented by the analytical tools of narratology. Narratology is here defined as "the study of the logic, principles, and practices of narrative representation" (Meister 2014[2009]: 623). As such, it is understood less as a means of interpreting a given narrative and more as a tool for exploring how it works, how its individual elements are organised and presented to a specific audience. While the concepts of narrative and narrativity have been gaining increasing prominence across different media and disciplines (cf. Heinen \& Sommer 2009; Ryan \& Thon 2014), this research deals with textual narrative. It shares contemporary narratology's growing interest in spatial issues (cf. Dennerlein 2009; Prince 2018a, 2018b; Ryan et al. 2016) and "classical" narratology's focus on text (Nünning 2003: 243-244). The concrete narratological models the present research relies on are discussed in Chapter 3.

The narratological perspective is complemented by theoretical and interpretative insights developed under the auspices of fairy-tale studies, a multidisciplinary research niche situated at the intersection of folklore studies (or folkloristics; cf. Harvilahti 2012) and literary studies. As indicated by its name, fairy-tale scholarship investigates the history, reception, production, and various manifestations of the fairy tale (cf. Haase 2008a; 2016). While it does not subscribe to a specific theoretical approach within fairy-tale studies, this research systematises and builds on the different observations on space and spatial transference they have presented. The works of Max Lüthi (1976[1969]a; 1986[1947]; 1987[1975]) and Alfred Messerli (2004; 2005; 2019) provide an especially important stimulus and model for the present research. A more thorough exploration of the different approaches to fairytale scholarship and the position of this research within its framework is presented in Chapter 2.

This research is by no means the first to address spatial issues in fairy tales. As Chapter 2 shows, there is a noteworthy corpus of works that (in)directly discuss the representation and - more extensively - meaning of space in fairy tales. However, while insightful and stimulating, existing research (with some notable exceptions, e.g. Messerli 2005) is predominantly interested in the metaphorical and symbolic meanings of space, rather than space as an autonomous and significant narrative element in its own right. In other words, existing scholarship is less interested in space as space and more in space as a representation of something 
else. In contrast, this research investigates space as a narrative element, rather than a symbol or stand-in; furthermore, it focuses on material rather than metaphorical space, meaning that it views space as a concrete, physical environment, and not merely a reflection of certain values, norms, meanings, etc. As it builds on existing research across the different theoretical approaches within fairy-tale scholarship, it also brings together its often disconnected strands, creates dialogue between them, and binds them into a more coherent foundation and model for the study of fairy-tale space.

By using narratology to examine the spatial aspects of the fairy tale, challenging the long-standing view of space as an inactive and irrelevant background to the action, and exploring spatial issues across short prose narrative genres, the present research aims to fill existing gaps in both narratological research and fairy-tale scholarship. Considering the importance of folklore and literary studies for fairy-tale scholarship, as well as the unique position of the Grimms' tales at the intersection of oral and written literature, folklore and booklore (Honko 1969: 50), it also strives to contribute to folklore and literary studies. Although spatial issues have been receiving increasing attention from literary scholars, their explorations have so far been predominantly linked to the study of longer narrative forms such as novels (e.g. Bragg 2016; Hones 2014; Thoene 2016; Zink 2018), epics (e.g. Jong 2012b; Tsagalis 2012), and short stories (e.g. Andrew 2007; Baak 1983; Correia 2017). In contrast, folklore studies, which do consider short narrative forms, have so far been mostly interested in place narratives, the relationship between literary and extra-literary spaces, and the space of the narrative, rather than space in the narrative (e.g. Bacchilega 2007a; Egeler 2018; Valk \& Sävborg 2018b).

It is worth pointing out that the present research deals with one specific manifestation of the multifaceted fairy tale: the Grimms' fairy tale. While it does hope to stimulate further inquiries into spatial issues in fairy tales, its findings by no means purport to have universal applicability - after all, not all fairy tales eschew descriptions or references to real-world geography. On the contrary, fairy tales included in The Thousand and One Nights or Giambattista Basile's Pentamerone $(1634,1636)$ are rich in elaborate descriptions and toponyms. Moreover, the extent and type of spatial references are bound to change depending on the media (printed text, film, illustrations, oral storytelling, etc.). For example, storytellers communicating tales to a live audience will also use gestures and other paraverbal elements to convey information, and utilise the environment in which the storytelling is taking place to create narrative space (Messerli 2005: 275). All the findings and observations presented in this thesis are therefore based on and valid for the corpus of the Grimms' tales; their applicability to other fairy-tale corpora remains to be determined by future research. 


\section{Outline of the thesis}

The various aspects of space and spatial transference in the KHM fairy tales that are at the centre of the present research are explored in five chapters, bookended by an introduction (the present chapter) and conclusion. Continuing the Introduction, Chapter 2 provides an overview of existing scholarship on fairy tales which whether indirectly or directly - addresses spatial issues. The first part of the chapter presents dominant twentieth- and twenty-first-century approaches to the fairy tale, specifically psychoanalytical, formal, literary, socio-historical, and feminist approaches, as well as two nascent approaches: queer/trans and disability studies. The approaches under discussion mostly view narrative space in purely symbolic terms or as a background for discussions on other aspects of the fairy tale (e.g. structure, characters) which constitute their primary research interest. The second part of the chapter presents studies in which space is the primary research focus, and which therefore explicitly and exclusively address the issue of space and/or spatial transference in fairy tales. By examining how each study and theoretical approach contributes to the discussion on spatial issues in fairy tales, the present research identifies the gap in existing research, and outlines the theoretical and methodological framework in which it is situated.

In order to examine the structure of fairy-tale space, Chapter 3 turns to narratology. Specifically, it applies the five-part model of spatial structure described by Marie-Laure Ryan (2014[2009]; Ryan et al. 2016), consisting of the narrative frame, setting, story space, storyworld, and narrative universe, to the fairy tale. Since this model is applicable to different types of narratives across genres, the present research also modifies it by introducing to it another category - the domain or realm. The fairy tale is described as a genre which encompasses two domains: that of human characters and that of otherworldly, magical characters. The discussion then expands to other KHM genres, which are viewed through the lens of space (specifically, the domain). However, the fairy tale's dyadic (dual-domain) nature has only limited usefulness when it comes to genre categorisation: on the one hand, it serves to distinguish the fairy tale from single-domain genres such as the animal or folk tale; on the other hand, it cannot be considered genre-specific since other short prose narrative genres, such as the legend or religious tale, are also built around two domains. The present research therefore suggests that it is not the mere existence of two domains that sets the fairy tale apart from other genres, but their spatial parameters, interaction, and means of crossing the interdomain boundary.

The interaction between the two fairy-tale domains, understood as a generic prerequisite, is explored in more detail in Chapter 4, which identifies three key features of the interdomain boundary: it can be crossed from both the side of the magical and the side of the non-magical, it can only be crossed temporarily, and to cross it, the characters have to fulfil certain conditions. The chapter pays special 
attention to these conditions, which differ for non-magical and magical characters, as well as the tales in the primary corpus which do not display these features. The chapter proceeds to ask whether the main features of the interdomain boundary are also genre-specific, i.e. whether they are unique to the fairy tale or found in other dyadic genres as well. To that end, the discussion expands to include dual-domain KHM genres other than the fairy tale, specifically didactic tales, legends, and religious tales, which are examined with regards to the features of the interdomain boundary and compared to the fairy tale.

Chapter 5 shifts the research focus from the structure of fairy-tale space to the means of its textual realisation. By examining the explicit (direct) and implicit (indirect) narrative and linguistic strategies the fairy tale uses to convey spatial information, the chapter questions the oft-repeated claim concerning the dearth of space-related information in fairy tales, especially the presumed incompatibility of the genre's parsimonious style and descriptions. The discussion encompasses the following strategies used to establish spatial information: naming, direct description, descriptised narration, and references to characters and objects. The chapter also examines the strategies used to establish the dimensions of individual spaces and relationships between them.

By taking a closer look at the main qualities (traits) of fairy-tale space, Chapter 6 challenges some of the long-held views of space, primarily the notion that it is little more than a container for characters and objects, and an inactive background against which events unfold without affecting it in any way. Following the view of space as relational, open, and unfinished, which has developed in the wake of the spatial turn (see, among others, Massey 1999a; 2005), the chapter argues that space is a dynamic narrative element that is continuously being (re)created and (re)negotiated through different relations within the narrative (relations between space and characters, objects, events, and other spaces), and between the narrative and the reader. Special attention is dedicated to the relationship between characters and space, which, as the chapter argues, is a two-way, dynamic relationship. An important component in this respect is spatial transference, which is viewed as both a result of and an impetus for character transformation. In addition to its dynamic and relational quality, the chapter also examines other frequently cited traits of fairy-tale space, primarily its abstract and unlocalised nature, as well as its ambivalence and transmutability. The chapter also asks whether, given the notion that the fairy tale seemingly takes place nowhere in particular, generated by its lack of concrete geography, it can be said that it can take place anywhere.

The Conclusion summarises the main findings of the present research and highlights its contribution to fairy-tale scholarship, narratology, and research on narrative space in general. It reiterates the importance of studying space in fairy tales by pointing to the new avenues of thinking about genre it opens up and remarking 
on the prominence of spatial issues in contemporary fairy-tale production across media, especially in the various fairy-tale pastiches (Jorgensen 2007: 217; see also Bacchilega 2013), such as the animated film Shrek (2001, dir. Andrew Adamson \& Vicky Jenson), Michael Buckley's series of children's novels The Sisters Grimm (2005-2012), or Bill Willingham's series of graphic novels Fables (2002-2015). 


\section{Narrative Space in Fairy Tales: Overview of Literature}

As stated in the Introduction, the narrative space of the fairy tale presents an underresearched area within fairy-tale scholarship, especially when compared to other narrative elements of the genre such as language (e.g. Levorato 2003; Lüthi 1986[1947]; Robinson 2010), themes, or characters (e.g Holbek 1987; Tatar 2003[1987]; Warner 1995; Zipes 2002[1988]). However, this does not mean that the topic has been entirely overlooked; on the contrary, a valuable corpus of scholarly texts on fairy tales addresses spatial issues to some degree, either within wider discussions on other aspects of the genre or as the primary research focus. This chapter provides an overview of existing scholarship ${ }^{13}$ and situates the present research within its theoretical and methodological framework.

Depending on the extent and type (direct or indirect) of engagement with spatial issues, several trends can be discerned within existing literature on fairy tales. Generally speaking, we can distinguish between texts that dismiss narrative space as an irrelevant genre feature and those that discuss it to some degree. The former category includes research which either entirely overlooks space or mentions it only in terms of its background function and unlocalised, abstract quality, frequently cited as staples of the genre. The fairy tale's perceived lack of concrete localisation has been a consistent part of definitions of the genre, from the Grimms' influential discussion on the place-bound legend (Sage) and the fairy tale (Märchen) which, in contrast, is "at home anywhere" ("überall zu Hause sein könne"; 1816: vi), through William Bascom's description of the genre as "almost timeless and placeless", meaning that, unlike the myth and the legend, it "may be set in any time and any place" (1965: 4), to contemporary definitions which continue to list "unspecified time and location" among the genre's distinguishing features (Joosen 2009: 197; cf. Lindahl 2018: 12-13). This lack of specific features coupled with the overall scarcity of spatial information provided by the narratives often leads to the reduction of

13 This refers to scholarship available in the languages the author uses (Croatian, English, German). Admittedly, studies on this topic may have been published in languages the author is not a user of. 
discussions of fairy-tale space to repetitions of such truisms, occasionally even prompting an outright dismissal of space as irrelevant. This is the case, for example, in Satu Apo's (1995) analysis of oral Finnish fairy tales. Although her research notes include entries about the "milieu" (i.e. time and space) of the recorded stories, Apo finds that its representation is "so simple" and "obvious from the event sequences of the plot schemes" that it does not merit a separate analysis (1995: 262, n.8). Furthermore, she claims, such an analysis would not yield new insights into the content of the tales.

At the centre of the present chapter are scholarly texts that do discuss narrative space in fairy tales. These can be divided into two categories: 1) research in which space is discussed indirectly, i.e. as a secondary concern within wider discussions on other aspects of the fairy tale such as genre or gender representation, where it serves mainly to illustrate and support the main arguments; and 2) research in which space is the main focus. The first part of the chapter focuses on indirect discussions on narrative space by providing an overview of the dominant twentieth- and twentyfirst-century approaches within fairy-tale scholarship. Special emphasis is given to the contribution of each approach to research on space. The second part of the chapter presents scholarship in which fairy-tale space is the primary research focus. By examining existing publications on the topic, the chapter aims to outline the wider theoretical and methodological framework in which this research is situated, and identify the gap it addresses.

\section{Space in fairy-tale scholarship}

This section provides an overview of the leading twentieth- and twenty-first-century scholarly approaches to fairy-tale research (here presented chronologically),${ }^{14}$ with special emphasis on their contribution to the discussion on narrative space. Specifically, the overview encompasses psychoanalytical, formal, literary, sociohistorical, feminist, queer/trans, and disability approaches to fairy tales. While none of them has systematically examined the issue of narrative space and spatial transference, these narrative elements frequently appear as a secondary concern in explorations of other topics the individual approaches are concerned with. Since comprehensive literature reviews of fairy-tale scholarship are available elsewhere (see, for instance, Holbek 1987: 187-400; Jones 2002[1995]: 119-140; Teverson

14 Earlier, nineteenth-century approaches, which primarily focus on the origin and dissemination of fairy tales, are not included in the present overview. 
2013), ${ }^{15}$ the following overviews are not meant to be exhaustive. Rather, their aim is to present the main ideas, theoretical underpinnings, and limitations of each approach, especially in so far as they address spatial issues.

\section{Space as symbol of the unconscious: psychoanalytical approaches}

Based on the premise that fairy tales have "a privileged connection to the unconscious" (Teverson 2013: 110), psychoanalytical approaches - specifically, Freudian and Jungian psychoanalysis - view these narratives as repositories of symbolic representations of individual (Freudian) or collective (Jungian) subconscious processes, "expression[s] of various longings, fears, aversions, or desires" (Jones 1951: 1). Fairy-tale spaces are similarly viewed in purely symbolic terms, as manifest representations of the latent content of the individual/collective psyche.

The father of psychoanalysis Sigmund Freud links fairy tales to dreams ${ }^{16}$ and expounds the benefits of fairy-tale interpretation in psychoanalytical practice (cf. Freud 1997[1913]). Taking his cue from Freud, Bruno Bettelheim also advocates the use of fairy tales in psychotherapy. In his influential The Uses of Enchantment: The Meaning and Importance of Fairy Tales (1991[1976]), he argues that the advantage of these stories lies in the fact that they rely on simple language, identifiable characters, and simple plots to stage the various inner conflicts children experience as part of the maturation process. By externalising these internal processes and promoting a sense of optimism through their happy endings, fairy tales provide their audiences with both the assurance that obstacles can be successfully overcome and the blueprint for achieving that goal.

Bettelheim indirectly recognises the importance of space and spatial transference in fairy tales by identifying the protagonist's departure from home as the first step on the symbolic journey of self-discovery and growth (1991[1976]: 79). Viewed from that perspective, the familiar space of home represents the conscious, while the unfamiliar and often perilous space of non-home figures as a symbol of the subconscious. According to Bettelheim, the unknown fairy-tale space par excellence is the "deep, dark", "near-impenetrable forest" in which the fairy-tale protagonist often gets lost, and which represents "the dark, hidden, near-impenetrable world of our unconscious" (ibid.: 93, 94). However, getting lost in the dangerous and isolated

15 The reader is also referred to relevant entries in prominent reference works, such as The Oxford Companion to Fairy Tales (Zipes 2002[2000]b), The Routledge Companion to Media and Fairy-Tale Cultures (Greenhill, Rudy, Hamer, \& Bosc 2018), and especially the 15-volume Enzyklopädie des Märchens (Ranke 1977-2015).

16 Although Freud's ideas about the parallels between fairy tales and dreams are arguably the most famous ones, he was not the first to make this connection (see Holbek 1987: 259-261). 
forest is a necessary impetus for the transition from the security of childhood into adulthood (ibid.: 226). Thus, although the exploration of the subconscious and resolution of internal conflicts and issues - represented by the (perilous) journey and/or quest which follows the protagonist's departure from home - is neither easy nor pleasant, it ultimately yields positive results.

Although Bettelheim's study has done much to popularise fairy tales as (ideal) children's literature - an achievement made all the more remarkable considering the book was published at a time when fairy tales were severely criticised by feminists and pedagogues for being (somewhat simplistically put) too sexist and too violent his methods and interpretations have received a significant amount of criticism. Many of the book's problems stem from the general drawbacks of psychoanalytical approaches, most notably the ahistorical examination of tales independently of their social, cultural, linguistic, etc. context, as well as the tendency to focus on a single variant of a given tale, generalising the conclusions based on such (from a folkloristic point of view) limited material, and presenting them as the (only) valid interpretation (Holbek 1987: 276-278). In doing so, Bettelheim effectively reduces each tale to a single central problem it supposedly illustrates, such as sibling rivalry, conflict between children and parents, or fear of abandonment (Bošković-Stulli 2012[1982]: 289), presenting patients' responses to individual stories as universally valid and divorced from their age, cultural/social/ethnic/educational backgrounds, etc. ${ }^{17}$ This tendency towards generalisation also marks his interpretations of space, which is seen only as a symbolic representation of the (un)conscious and setting for the different stages of the maturation process.

Other followers of Freud shifted their research focus from the patient to the fairy tale itself, which thus became a subject of study in its own right, rather than a tool for understanding the individual's subconsciousness. Of special note are the contributions of folklorists, who attempted to overcome some of the perceived limitations of the psychoanalytical approach by (among other things) considering different variants of the same tale and their socio-historical contexts. Particularly notable is the work of Alan Dundes, who consistently argues for the usefulness of psychoanalysis as an interpretative tool, providing models for its successful application in folklore research. For example, in his study of "The Maiden without Hands" (KHM 31, ATU 706, 930), Dundes (1987) considers the different versions of the story published in the different editions of the KHM, as well as other variants of the analysed tale type (see also Dundes 1988). His reading of select KHM tales identifies various individual spaces as manifestations of latent sexual content. For example, the well in "Mother Holle" (KHM 24, ATU 480) and the forbidden

17 For further criticism of Bettelheim see, among others, Darnton (1999[1984]: 12-13), Dundes (1991), Heisig (1977), and Zipes (2002[1979]: 179-205). 
chamber in "Fitcher's Bird" (KHM 46, ATU 311) - both read as stories of female sexual maturation - are interpreted as symbols of female genitalia (Dundes 1987: 56). In a similar vein, various enclosed spaces such as caves, castles, or chambers are seen as repositories of repressed psychological content (ibid.).

Initially a disciple of Freud, Carl Gustav Jung proposed a different understanding of the human psyche, one that highlights its collective aspects. As a particularly important part of the so-called collective unconscious, Jung identifies timeless and universal symbolic forms or "primordial images" he terms archetypes (1964: 67). For Jung, fairy tales and myths present an especially rich source of archetypes: the fairy tale in particular concretises archetypes, represented by individual fairy-tale motifs and characters, its plot symbolising a variety of unconscious processes such as individuation, which includes self-actualisation and increasing individual consciousness (1991[1969]: 217, 222). Jung's disciple Marie-Louise von Franz, the author of the most extensive body of work dedicated to Jungian analysis of fairy tales to date, elaborates on this notion, explaining that fairy tales contain archetypes in their basic and simplest forms, and as such present the "purest and simplest expression of collective unconscious psychic processes" (1996[1970]: 1). Her interest lies with fairy-tale characters, which, she claims, should not be seen as representations of social groups or types of people, but as archetypes (Franz 1980: 9). Though central to Jungian psychoanalysis, archetypes are also among its most contested elements. As numerous critics have pointed out, they are too vaguely defined and approachable only indirectly, i.e. via their (infinitely varied) manifestations. As such, they elude direct, systematic study, which often results in "personalistic" interpretations, which many deem unscientific (Franz 1996[1970]: vii-viii). Moreover, feminist critics have pointed out that archetypes are not the universal, timeless entities Jung believed them to be, but rather social and cultural constructs, products of a very specific time, space, and (patriarchal) worldview (see, for example, Goldenberg 1976; Lauter \& Schreier Rupprecht 1985; Rowland 2002).

The basic principle that informs Jungian readings of space is similar to the one that underlies Freudian approaches: the space of home is linked to the conscious, the non-home to the unconscious. Like Bettelheim, Franz also highlights the importance of the forest, "a region where visibility is limited, where one loses one's way, where wild animals and unexpected dangers may be present" (1996[1970]: 127). In that respect, the forest is comparable to another "symbol of the unconscious", the sea (ibid.). However, unlike Freudian readings, Jungian interpretations consider the collective (rather than the individual) unconscious and link the departure from home to the process of individuation. In the (dangerous) forest, the protagonists are often deserted, tested or transformed, which leads to their eventual growth and development into adult, independent individuals, which many interpreters see as the central topic of the fairy tale (Schwartz 1956: 755). 
As stated at the beginning of this section, psychoanalytic readings view fairytale spaces in purely symbolic terms. Seen from that perspective (i.e. as stand-ins for something else), they are neither interesting nor relevant in themselves, but only in terms of what they can reveal about the "hidden" or latent content of the story. Holbek's criticism of psychoanalytical approaches as producing similar interpretations (often "decided in advance") and finding similar meanings in different fairy tales, regardless of their actual content (1987: 276), is therefore also applicable to the case of fairy-tale spaces, which tend to be ascribed fixed meanings. Regardless of their concrete portrayal and role in the story, unfamiliar, natural spaces such as the forest are typically seen as representations of the unconscious. In contrast, the familiar space of home - again, regardless of its positive/negative portrayal in individual stories - is regularly associated with the conscious, while enclosed spaces other than the home are often seen as "containers" of repressed psychological content. The same goes for spatial transference, viewed primarily as a symbolic representation of the development process. Ultimately, psychoanalytic approaches to the fairy tale are not interested in narrative space per se, but in what it reveals about the different aspects of the (individual/collective) unconscious.

\section{Space as connective and structural principle: formal approaches}

Unlike the earliest approaches in fairy-tale scholarship, such as the mythological or historic-geographic ("Finnish") school, which were predominantly interested in the origins and diffusion of fairy tales, ${ }^{18}$ formal approaches shift the focus of study to the narratives themselves. This especially pertains to structure, understood as "the internal relationship through which constituent elements of a whole are organised", and the constituent elements themselves (Maranda \& Köngäs Maranda 1971: 16). From a formal point of view, the significance of space to the fairy tale lies primarily in its function as an organising principle, i.e. a means of dividing the plot into distinct episodes and connecting individual episodes via spatial transference.

Formal approaches to the fairy tale comprise two similar theoretical orientations: structuralism, which largely generated from Claude Lévi-Strauss's study of myth, and focuses on the constituents, their connection to extra-textual reality (e.g. social, historical, cultural context), and the underlying laws of structure (Liberman 1984: xxxiv), and formalism, commonly linked with Vladimir Propp's analysis of the fairy tale. Given Propp's interest in fairy tales (Lévi-Strauss studied myths) and the 
immense influence of his work, the present section will focus on his analytical model and its subsequent modifications.

Dismissing content as too unreliable a criterion for genre classification, Propp builds his definition of the fairy tale on structure, ${ }^{19}$ which he views as stable, unchanging, and genre-specific ${ }^{20}$ (2012 [1984]: 148, 151, 172). ${ }^{21}$ In The Morphology of the Folktale (first published in Russian in 1928), Propp claims that all fairy tales share the same underlying structure, described as "any development proceeding from villainy $[\ldots]$ or lack [...], through intermediary functions to marriage [...], or to other functions employed as dénouement" (1968[1928]: 92). The structure of individual tales consists of a smaller or greater number of stable units of action Propp terms functions (ibid.: 21). He identifies a total of 31 functions, which always appear in the same order (for instance, the setting of a prohibition is always followed by its breaking), but not all of them are found in all fairy tales (ibid.: 64). The roles of fairytale characters are similarly limited to seven functions or spheres of action (hero, false hero, villain, donor, helper, princess or sought-for person and her father, and dispatcher; ibid.: 79-80). At the heart of Propp's morphology $y^{22}$ is the opposition between constants (the stable and unchanging underlying structure of the fairy tale) and variables (the endlessly varying concrete manifestations of the basic structural elements). Thus, the functions themselves are stable and unchanging, while their manifestations in individual tales are extremely diverse, making the fairy tale simultaneously uniform and multifaceted (ibid.: 21). For example, the function of villainy is described as the infliction of harm on the protagonist's family on the part

19 Unlike formalism, which relies on the separation and opposition between (concrete) form and (abstract) content, structuralism makes no such distinction, perceiving form and content as being "of the same nature, amenable to the same type of analysis" (LéviStrauss 1984[1958]: 179).

20 Despite his insistence on the uniqueness of fairy-tale structure, Propp identifies the same or similar structure in some novellas, animal tales, and legends (1968[1928]: 99, 101).

21 Propp ascribes what he sees as the "total uniformity in the construction of fairy tales" (1968[1928]: 105) to their unique, common origin, explored in more detail in his Historical Roots of the Wonder Tale (1990[1946]).

22 While Propp's study proved to be the most famous and influential, it was certainly not the first to propose a formal approach to the study of fairy tales. Much of Propp's theory (and formal analysis in general) is anticipated by early-twentieth-century folklorists such as Axel Olrik (1965[1909]), who attempted to identify and describe universal formal rules (or, as he calls them, epic laws) that regulate folk narratives, such as the law of contrast, repetition, opening/closing, etc. Written two years before but published in the same year as Propp's Morphology, Aleksandr I. Nikiforov's article "Towards a Morphological Study of the Folktales" (1975[1928]) also discusses the stability of functions and the variety of possible characters that can perform them (for a discussion of Propp's predecessors, see Jason 1977c). 
of the antagonist. In concrete tales, this can take on a number of forms, from the abduction of a family member, through theft or property damage, to bodily injury or murder (ibid.: 30-35). From a purely formalist point of view, what matters are the actions which move the plot forward (in this case, harming the protagonist's family), while their concrete manifestations (theft, kidnapping, etc.) and the identity of the characters who perform them (e.g. a dragon, witch) are almost irrelevant. In fact, the substitution of one type of action or character with another would presumably not alter the course of the narrative.

While he does not discuss space separately, Propp indirectly recognises its significance through frequent mentions and discussions of spatial transference, which forms the basis of many of his 31 functions, some of which have the spatial component inscribed in their definitions (e.g. departure, spatial transference between two kingdoms, return). Moreover, individual functions are bound to specific spaces. To quote Franco Moretti (1998[1997]: 71):

The first eleven [functions], for instance, can only happen in the "initial world"; the following three, in the space of the donor; then five in the "other kingdom", three more or less on the border, and the final nine again in the initial world.

Moretti even goes so far as to claim that space plays such an important role in Propp's Morphology that it might as well be called the "topography of the Folktale" (ibid.: 72 , original emphasis). In his other writings, Propp explicitly identifies spatial transference as the structural basis of the genre (1990[1946]: 77), describing the basic structure of the fairy-tale narrative as a series of transferences of the wandering hero/ine (ibid.: 34-35).

The importance and influence of Propp's Morphology can hardly be overstated as researchers from a variety of disciplines across the humanities and social sciences have adopted, modified, and expanded his analytical model (cf. Dundes 1968: xi). However, his research methods and results have also been criticised for simultaneously being too expansive and too limited (Canepa 1999: 20). The latter complaint stems from his focus on a single type of narrative (adventure fairy tales with male protagonists; $\mathrm{cf}$. Apo 1980) and use of a fairly limited and uniform corpus (100 tales from the same author/collector, written in the same language, and derived from a single socio-cultural context) as the basis for conclusions with purportedly universal application. ${ }^{23}$ On the other hand, Propp's analytical model proved to be

23 Propp justifies the narrowness of his corpus by referring to the repetitiveness and uniformity of the fairy tale. In other words, since the underlying structure is always the same and the number of its components limited, expanding the corpus would presumably not yield new results (Propp 1968[1928]: 23-24). 
applicable well beyond the scope of the fairy-tale genre, as demonstrated by numerous studies of, for example, proverbs (Dundes 1975), riddles (Georges \& Dundes 1963), games (Dundes 2007[1964]), films and TV series (Hala 1992; Harris 2008; Murphy 2015; Wright 1975). The wide applicability of Propp's model brings into question his central argument about the uniqueness of fairy-tale structure. His claim about the importance of spatial transference for that structure can be brought into question on the same grounds, as spatial transference (especially the journey) constitutes what is perhaps "the most archaic and fundamental type of plot" (Baak 1983: 77), and may even be seen as a prerequisite of narration in general (Malmgren 1985: 113-114). As such, it is by no means specific to the fairy tale.

Numerous scholars - among them Alan Dundes (1964), Claude Brémond (1970), and Bengt Holbek (1987) - have revised Propp's model, adapting it to their (structural) analyses of different groups of folktales. Two of these revisionists Eleazar Meletinskij (lead author in a collaborative project) and Heda Jason highlight the spatial component in their structural models, which is why they will be discussed in more detail. Meletinskij et al. (1974[1971]) modify Propp's model by grouping his basic units (functions) under more abstract categories of tests: specifically, the initial or preliminary test, the basic test, and the additional test. Moreover, they highlight the importance of binaries for the underlying structure of the fairy tale, most notably the own/foreign juxtaposition, which is translated onto the spatial plane. In heroic tales, it is manifested on the macrocosmic level, where it takes on the form of the juxtaposition between one's own or "our" kingdom, and a distant foreign kingdom; in contrast, in tales about children's adventures it is manifested on the microcosmic level, as the juxtaposition between home and (the near-by) forest (Meletinskij et al. 1974[1971]: 94). The two components of the central binary take on specific values (own is positive, foreign negative) and are crucial for defining characters (for instance, the villain is always "foreign"; ibid.: $120, \mathrm{n} .19)$. The authors identify space (together with time and situation) as a means of text segmentation (ibid.: 125) and spatial transference as a means of connecting individual episodes into the overall narrative (ibid.: 127).

Jason builds on the idea of textual segmentation and develops the concept of connectives, defined as pieces of information or transitions in state, time, or space (1977a: 101-104). However, the distinction between information and other type of connectives is not always clear (after all, to notify readers about a change of location in the story is also to provide them with information). For example, in one of her tale analyses, the sentence "The woman returned home" is cited as a space connective; however, when the woman runs out to the seashore to wash her clothes, this is labelled as an information connective, despite the change of location (ibid.: 109). Jason consistently considers narrative space in her explorations of different folklore genres such as legends (1971), numskull tales (1972), swindler novellas (1979), and 
different sub-types of the fairy tale (1988). She highlights the links between spaces and characters, claiming that the presence/absence of a specific type of character lends a given space its particular quality. In that sense, "[s]patial boundaries [...] symbolize borders between entities of different qualities" (Jason 1988: 23). She is especially interested in the role of temporal and spatial connectives in organising the fairy-tale plot into individual scenes/episodes (ibid.: 37, 59). Despite the ubiquity of spatial issues in her research, Jason's work demonstrates the same limitations as that of Propp and Meletinskij, as it views space almost exclusively as a connective, i.e. in the context of characters' transferences which signify the end of one and the beginning of another episode. Thus, space (connective) is considered in isolation and opposition to action (episodes or moves), primarily as a means of marking off breaks between episodes. Such an approach fails to consider that actions themselves inevitably have a spatial component and that, as numerous applications of Jason's model have demonstrated, spatial transference is also found within (not just between) episodes. In her analysis of the innocent persecuted heroine tales, Ilana Dan voices this problem, pointing to the often unclear distinction between spatial transference as a connective and spatial transference as a function in Jason's model (1977: 15). For instance, function 3 in Dan's analysis is not labelled as a spatial connective, even though it consists of the heroine running away from home or being banished, an action which includes spatial transference (ibid.). While she does draw attention to this problem, Dan does not propose a solution for it or attempt to modify Jason's model.

To sum up, formal approaches consider space primarily in terms of spatial transference, which, in turn, is viewed as a significant principle of organisation as it serves to delineate individual episodes and shifts between them. While fairy-tale episodes are typically linked to individual spaces so that spatial transference also sets up a new episode, this view does not consider space/spatial transference in its own right, but only through its relation to structure. Furthermore, it fails to consider genre-specific aspects of spatial connectives, meaning that the claims about their importance - while valid - can be made for spatial transference in virtually any genre.

\section{Space as the background for action: literary approaches}

The literary or aesthetic approach highlights the status of fairy tales as literary or artistic creations, often combining folklore and (children's) literature studies. As exemplified by the works of (among others) Steven Swann Jones (2002[1995]), to some extent Maria Tatar (2003[1987]) and Jack Zipes (2006; 2012), and especially Max Lüthi (1970[1962], 1986[1947], 1987[1975]), literary approaches are mostly preoccupied with the style of the fairy tale, its appeal and aesthetic influence on 
(young) audiences. Representations of space in the fairy tale are seen as mirroring the genre's overall style, while space itself is mostly perceived as a passive background which exists mainly in relation to the characters and becomes activated only when (and for as long as) the plot demands it.

In The European Folktale (1986[1947]), the most prolific and influential proponent of the literary approach Max Lüthi analyses the style of the fairy tale, which, he believes, reflects the genre's underlying meanings and unique worldview. He identifies the following features of the fairy-tale style: one-dimensionality, depthlessness, abstract quality, isolation, sublimation, and all-inclusiveness. The one-dimensionality of the fairy tale is seen in the lack of surprise or fear which characterises the encounter between human and "otherworldly" characters. Unlike legends in which human characters experience strong emotional reactions (shock, fear, surprise, etc.) when faced with ghosts or demons, fairy-tale characters "do not feel that an encounter with an otherworld being is an encounter with an alien dimension" (Lüthi 1986[1947]: 10); rather, they perceive everything as belonging to the same spiritual dimension. Because the "otherworldy" creatures and occurrences constitute a part of everyday experience for human characters, encountering them fails to elicit any kind of emotional response. The fairy tale's lack of depth is manifested in the genre's treatment of objects (prevalence of objects with a pronounced linearity, rather than spatial depth, such as rings, staffs, and animal hairs; ibid.: 11) and characters, who are devoid of psychological and emotional depth (ibid.: 13, 18). The abstract style of the fairy tale is highly economical, focusing only on narrative elements that move the plot forwards. It shows without explaining, justifying, or describing; it frequently includes (threefold) repetitions and fixed formulas, and translates all internal processes and changes onto the external plane (ibid.: 24-29, 32-34). Moreover, the fairy tale depicts all events, characters, and objects in isolation; thus, the outcome of one episode typically has no bearing on the following one, which is why characters often repeat the same mistakes over and over again (ibid.: 39). Similarly, places that have been visited and objects that have been used are never mentioned again (ibid.: 60-61). For Lüthi, content is an unreliable criterion for defining the fairy tale because no single motif is inherent to the genre but can be found in other types of narratives as well. What is, however, unique to the fairy tale is its sublimating style, which can take any (non-fairy-tale) motif, empty it of its original content, and lend it a "fairy-tale" quality. Because of its ability to incorporate and adapt any motif, the fairy tale, according to Lüthi, is all-inclusive or world-encompassing (ibid.: 66, 73-76).

Some of the main shortcomings of Lüthi's approach are acknowledged by the author himself in the introduction to his study of the European folktale. Since his focus is on the general ("the principal formal traits of the European folktale", or "basic form that all folktales have in common"; Lüthi 1986[1947]: 3) at the expense 
of the particular, he ignores what he terms "superficial differences" (ibid.) among the individual tales in his corpus that reflect the particularities of their storytelling communities and socio-cultural contexts. Instead, he opts for an essentialist approach that views fairy tales as bearers of universal, "unchangeable humanistic values" (Bacchilega 1997: 8). Moreover, his musings on fairy-tale style do not extend to its origin or meaning (Holbek 1987: 325), while his observations - based largely on published collections of fairy tales - may not be applicable to oral narratives (Lüthi 1986[1947]: 107-108).

Lüthi's interest in language and style as mirrors of "a particular image of image of man and his world" (1987[1975]: ix) coupled with his attempt to "establish the essential laws" of the fairy tale (1986[1947]: 107) have inspired frequent comparisons of his work to that of Alex Olrik (1965[1909]) and André Jolles (1969[1930]). Olrik is famous for defining the so-called epic laws or "rules of composition" (1965[1909]: 131) of the Sage (used as an umbrella term for a variety of oral narratives) which distinguish it from written literature, such as the law of repetition, contrast, or opening and closing. Unlike Lüthi, who focuses on the fairy tale, Olrik highlights the similarities between the different genres included under the Sagen umbrella and applicability of his epic laws across genre boundaries. However, as scholars such as Bruce Rosenberg have pointed out, even such a designation of Olrik's work seems "too restrictive" (1991: 18); namely, many of his epic laws resemble the principles outlined in Aristotle's Poetics, proving applicable to narrative in general, rather than oral narrative alone (ibid.: 17). Furthermore, Olrik's laws $^{24}$ are understood as being super-organic, meaning they are beyond human control and instead actively control individual narrators who cannot but "blindly obey" them (Dundes 1965: 130).

While Olrik remains rooted in structure, Lüthi focuses on language and style, which he believes stem from the unique worldview of the fairy tale. Jolles (1969[1930]) assumes a similar position in his study of the so-called simple forms of folk narrative (including the fairy tale), which are - like Olrik's Sage - distinguished from literary forms and seen as linguistic expressions of certain types of mental or spiritual activity. Specifically, Jolles links the human labour of production (farmer), creation (artisan), and interpretation (priest) to language: on the one hand, everything produced, created, interpreted is named in language; on the other hand, the labour itself is reflected in the linguistic processes of production, creation, and interpretation (1969[1930]: 11-22). Although he does not use Lüthi's vocabulary, Jolles recognises the same sublimating tendency of the fairy tale, which, he notes, transforms whatever on "observations not of lawful certitude but of general tendencies" (ibid.: 16). 
is inserted into it following its dominant principles (ibid.: 233). These principles reflect the fairy tale's naïve morality and the significance of the marvellous, which Jolles describes as both necessary and self-evident. Furthermore, the fairy tale lacks traces of a single author's individual expression, making it general and plural. Jolles finds a reflection of all these principles in the characters, events, and the unspecified setting of the fairy tale. The fairy tale, he writes, takes place "nowhere and everywhere [...] never and always", because a more concrete, historical setting would clash with the power of the marvellous (ibid.: 244).

In both The European Folktale (1986[1947]) and his other writings (1976[1969]a, 1976[1969]b), Lüthi considers fairy-tale space to some degree, offering somewhat contradictory observations about it. He indirectly acknowledges the importance of space by identifying spatial imagery (the choice and treatment of individual spaces), and the spatial organisation of the human and the "other" world as a means of differentiating between the fairy tale and legend. Individual spaces are even chosen as symbols of the two genres, with the "uncertain form" of the cave seen as representative of the legend and the geometrical, sharply delineated castle of the fairy tale (Lüthi 1976[1969]a: 21). Furthermore, the two genres, he claims, show a proclivity for different spaces, with legendary figures dwelling in natural habitats such as caves, while their fairy-tale counterparts commonly inhabit (human) houses (Lüthi 1976[1969]b: 28). When featuring the same spaces, the two genres treat them differently: for example, the fairy tale makes no attempt to explain the appearance of an enchanted or empty castle, which remains "ageless and perfect" despite the passage of time (Lüthi 1987[1975]: 71); in contrast, the legend is more vocal about the significance and origin of such locations, which also bear clear traces of time passing (ruins are mentioned as a staple of the genre; ibid.: 71, 121).

Perhaps the most important space-based distinctions between the fairy tale and the legend identified by Lüthi are their scope and emphasis on distance (or lack thereof): legends are bound to a single location, while fairy tales cover a much wider geographical area, which explains the crucial importance of the protagonist's departure from home. While the existence of two realms - one human, the other otherworldly - is characteristic of both the fairy tale and the legend, what is genrespecific is their spatial organisation, which reflects their essential one-/twodimensionality (Lüthi 1986[1947]: 7-8, original emphasis):

In legends otherworld beings are physically close to human beings. They dwell in his house, in his field, or in the nearby woods, stream, mountain, or lake. [...] But spiritually these house kobolds, nickelmen, Fänggen, alpine spirits, and wild men inhabit a world of their own, and human beings encounter them as the Wholly Other. In folktales exactly the opposite is true. Otherworld beings do not dwell side by side with the inhabitants of this world. Rarely does the hero meet 
them in his house or village. He comes across them only when he wanders far and wide.

In other words, because the legend perceives humans and otherworldly beings as belonging to distinct spiritual dimensions there is no need to separate them spatially (ibid.: 9). The opposite is true of the one-dimensional fairy tale, which has to insert large distances between human and otherworldly characters to compensate for their lack of "inner", experiential distance (ibid.).

Lüthi's overall attitude towards space in fairy tales is somewhat contradictory, ${ }^{25}$ evoking Propp's remark that space is both "an indispensable structural element" of the fairy tale and "almost non-existent" as it does not affect the story or characters (1990[1946]: 78). In a similar vein, Lüthi (indirectly) recognises space and especially spatial transference as important elements in distinguishing genres and isolating characters. On the other hand, he points out that since the fairy tale is "a story about people", everything else, including objects and environments, exists only through relationships to the characters, most notably the protagonist (Lüthi 1987[1975]: 14). Furthermore, he claims, individual locations "do not serve to establish a setting" and are only mentioned "if the plot is dependent upon them" (Lüthi 1986[1947]: 38). The notion that individual spaces are significant only as the setting for the action is reinforced in their treatment as so-called truncated motifs, i.e. elements which exist in isolation and disappear from the story once they have served their purpose (ibid.: 61). As a figure which "has no environment" (ibid.: 18, original emphasis), the isolated protagonist moves between spaces without interacting with or being affected by them. This lack of interaction reinforces the notion of space as a passive background which comes into being only when (and for as long as) the plot needs it to.

Despite his explicit reinforcement of the traditional space-as-background view, Lüthi's research nevertheless provides insightful observations on space and the relationship between space and characters. Even more importantly, it also highlights the genre-specific aspects of spatial organisation in the fairy tale, which is why the present research takes it as its starting point (see below).

\section{Literary and extra-literary landscapes: socio-historical approaches}

As their name suggests, socio-historical approaches rely on the premise that fairy tales bear the traces of the specific historical, social, and cultural conditions in which they are created and disseminated. This marks a radical departure from the traditional (and 
somewhat romantic) notion of fairy tales as a timeless, universal, and "monolithic genre that speaks to some unchanging notion of human needs or aspirations" (Canepa 1999: 265, n.68). For many proponents of this approach - most notably Lutz Röhrich (1991[1956]) and Robert Darnton (1999[1984]) - the tales serve almost as historical documents, the study of which can shed light on the living conditions, customs, and belief and value systems of their respective story-telling communities (Röhrich 1991[1956]: 92; Weber 1981: 96). On the other hand, the study of appropriate sociohistorical contexts is seen as a key resource for understanding the meaning and functions of individual tales. Often seen as a reaction to more text-oriented readings which disregard the extra-literary frame in which texts and their meanings are produced, socio-historical approaches have been criticised for showing too little interest in textual analysis and therefore ignoring textually produced meanings. Furthermore, their focus on individual contexts often leads to a disregard of the tales' wider, cross-cultural circulations and transformations (Jones 2002[1995]: 134).

While explorations of fairy-tale space produced within this approach typically revolve around the relationship between literary spaces and their extra-literary counterparts, they are by no means a simple matter of finding "real-world" equivalents for spaces mentioned in the story, or explaining the prevalence of particular spaces in stories through reference to the geographical context in which they are told (simply put, stories shared by communities that occupy, for example, wooded realms will be set in forests). Some researchers, including Röhrich, do point to setting as a culture- and nation-specific feature of the fairy tale. Comparing German and French folktales, Röhrich notes that the former are typically set in forests, which are "more essential" to the German tradition than other narrative traditions (1991[1956]: 179), while the latter prefer "fair landscape with plentiful nut and fruit trees" (ibid.: 167). However, he is ultimately more interested in extraliterary space, i.e. the geographical context and its influence on narratives, identified in (among other things) specific linguistic features (e.g. the use of dialectal words), as well as references to food, drink, animals, and religious practices.

Although most famous for his study of fairy-tale structure, Propp did not entirely dismiss content, dedicating his Historical Roots of the Wonder Tale (1990[1946]) to tracing the origins of individual motifs to (ancient) social structures, institutions, and practices. ${ }^{26}$ Images of the world of the dead and initiation rituals are identified as two

26 As the example of Propp shows, the different approaches to fairy-tale scholarship although discussed separately in this overview - are not mutually exclusive. On the contrary, many scholars combine different theories and methods in their work, such as feminist and psychoanalytical (Schanoes 2014; Zlatar 2007), socio-historical and psychoanalytical (Zipes 2005), or feminist, socio-historical, and psychoanalytical approaches (Tatar 2003[1987], 2004b). 
main sources of fairy-tale content, to which almost any motif can be traced (1990[1946]: 534), including the identity and representation of various spatial items. For Propp, the "impenetrable, dark, mysterious" fairy-tale forest in which the protagonist gets lost and meets a magic helper is essentially the forest in which ancient communities performed their initiation rituals (ibid.: 92). This ancient forest also concealed so-called initiation huts in which the initiates would be subjected to a symbolic death; in the fairy tale, this building becomes the cottage in the woods, which often guards the entrance to the realm of the dead. Other isolated buildings such as (large) houses or castles are traced back to so-called male houses, where newly initiated young men could spend time before marriage (ibid.: 176-177). The representation of the otherworld in particular acts as a mirror for different societies which regularly ascribe to it "the same life and forms of material production they themselves are familiar with" (ibid.: 443). Thus, hunting societies populate their version of the otherworld with animals, anthropomorphic creatures (e.g. the snake or wolf emperor), or characters who can control animals (ibid.: 435-436). While based on a wide range of historically, culturally, and even generically diverse texts (fairy tales and myths), Propp's readings are symptomatic of the aforementioned limitations of the socio-historical approach in that they treat the stories that constitute the research corpus purely as "historical material" (ibid.: 224). All story elements, including space, are viewed only in relation to the social institutions or historical practices they represent, with little attention dedicated to the processes in which extra-literary content is given a literary shape and the artistic means of its modification. Thus, the fairy-tale forest, for instance, is not important as a story setting but as an indication that the storytelling community performed its initiation rituals in forests.

Robert Darnton's (1999[1984]) analysis of French fairy tales of the ancien régime which views the stories as immediate expressions of the grim reality (shortage of food, plague, high death rate, child abuse, etc.) and world view of the French peasantry of the time, ${ }^{27}$ pays special attention to the underlying spatial juxtaposition of home/village and the open road. The stories' dual setting, claims Darnton, mirrors "the lives of peasants everywhere in eighteenth-century France" (1999[1984]: 34), which typically unfolded along the home-open road axis; moreover, the protagonists engage in spatial transference (primarily leaving home) prompted by real-life troubles, such as poverty, famine, or search for work/apprenticeship (ibid.: 36-37). By portraying the environments and situations

27 Zipes takes issue with Darnton's view of fairy tales as direct expressions of the peasants' experience on account of its disregard for their mediation via "literate collectors, editors, and publishers", and the fact that many stories entered the oral tradition from literary sources (2002[1988]: 70). 
familiar to the audience, Darnton claims, fairy tales become repositories of the common knowledge of the French peasantry, telling "peasants how the world was put together" and providing them with "a strategy for coping with it" (ibid.: 53).

Eugen Weber's article (1981) on the rootedness of fairy tales in the reality of their audience similarly links narrative settings to the audience's experience of their own environment. For instance, negative connotations of the fairy-tale forest as a place where danger lurks and one can easily get lost stem, the author claims, from the fear-inducing knowledge of the audience that, in reality, this space is filled with robbers and wild animals (Weber 1981: 97). Like Darnton, Weber finds the fairytale motif of leaving one's impoverished home in search of a better future to be "absolutely true to life" (ibid.: 98).

Some proponents of the socio-historical approach such as Jack Zipes (2002[1979], 2006[1983]), Nancy Canepa (1999), and (to a large extent) Ruth Bottigheimer (1987), have attempted to overcome some of the limitations of the approach by considering both textually and contextually produced meanings. Analyses by Zipes and Canepa in particular demonstrate how examining the sociohistorical and political context of a given narrative can help explain the prominence and use of a given space within a particular corpus. As their studies of the forest in the fairy tales of the Brothers Grimm (Zipes 2002[1988]) and Giambattista Basile (Canepa 1999) show, the way a particular space is used and depicted in a given text can also reveal much about its author (his or her beliefs, ideology, etc.) and the social, political, cultural, and literary context in which he or she operates.

Much of Zipes's research deals with the development, changing social functions, and ideological uses of the fairy tale throughout history and across media, especially the "socio-historical forces" that led to the transformation of the "pre-capitalist folk form" that is the oral fairy tale (or, as Zipes calls it, folk/wonder tale) into the "bourgeois art form" of the literary fairy tale (2002[1979]: 23). His extensive study of the Grimms and their collection includes a consideration of the significance of the forest in their fairy tales and other writing. Standing in contrast to civilisation, the forest in the Grimms' fairy tales is 'the place where society's conventions no longer hold true" (Zipes 2002[1988]: 67), which belongs to everyone in equal measure, thus providing a platform for righting social wrongs and rising above one's status (ibid: 79). Turning his attention to extra-literary elements, Zipes (quoting Wilhelm Riehl) links the equalising role of the fairy-tale forest to the fact that German woods were traditionally under common ownership, as the idea of privately owned forests was introduced fairly late (ibid.: 88). Its status as a democratic, shared property coupled with its physical separation from cities and other human spaces, Zipes argues, makes it an ideal location for the transformation and social rise of the (often wronged) protagonist. Furthermore, as a physical remnant of ancient times and a link to the past, the forest assumes a prominent place within the German Romantic movement 
and nation-building agenda, where it comes to be perceived as the key to restoring the lost national unity, a kind of repository of German tradition and heritage, containing (ibid.: 68)

the essential truths about German laws, customs, and culture [...], the connections that might engender a deeper understanding of [...] present-day Germany and might foster unity among German people at a time when the German principalities were divided and occupied by the French during the Napoleonic Wars. The Volk, the people, bound by a common language but disunited, needed to enter old German forests, so the Grimms thought, to gain a sense of their heritage and to strengthen the ties among themselves.

In Zipes's model for a socio-historical reading of a particular space, the wider historical, ideological, political, and literary context are all used to explain not only the choice of a given space as the setting, but also its prominence across stories and role in individual narratives.

As the title of her monograph - From Court to Forest - suggests, Canepa considers (among other things) the spatial dimension of Basile's fairy tales, acknowledging its relevance on the structural, thematic, and linguistic level, as well as its role as a "repository of a wealth of 'anthropological' information" (1999: 207). She is especially concerned with the link between characters and spaces: Basile's royal characters typically come from "whimsically named imaginary kingdoms", while those of lower social standing are grounded in the real-world geography of seventeenth-century Italy, primarily Naples and its surrounding villages (ibid.). ${ }^{28}$ Contrasting these real-life geographies, which retain much of their real-life hardships, with the humorous, sexually suggestive names of the fictional geographies of the royal characters, Basile effectively uses space to "articulate a critique of social reality and the power hierarchies of his time" (ibid.: 111). A prominent place in Canepa's analysis belongs to "one of the most emblematic topographies" of both Basile's collection and the fairy-tale genre in general - the forest (ibid.: 175). Basile's tales problematise the traditional view of the forest as a wild foil to civilised society, presenting it instead as an idyllic and pastoral countercourt, which serves as an empty slate of sorts onto which characters can project their fears and desires (ibid.: 214). While it does provide "a haven from the turmoil of the civilized world" (ibid.: 213), the forest is nevertheless shaped by human activity and a site of intense social interaction. Basile's portrayal of the forest (and other fictional landscapes) also presents a departure from the tradition of the economical oral tale 
by engaging in elaborate descriptions characterised by a "hypertrophic abundance of detail", which are "often marginal to the unfolding of the principal events" (ibid.: 207). Seeing that that the author's linguistic virtuosity comes to the forefront precisely in representations of the landscape, Canepa views the forest as symbolic of Basile's transformation of the traditional fairy tale. Unlike the Grimms, who ascribe to the forest a restorative function, and value it as a site of rediscovering and revitalising tradition, Basile assigns it a subversive function, and uses it to challenge both social and literary tradition.

As Zipes's and Canepa's work demonstrates, the socio-historical approach has overcome its initial limitations of studying space that stemmed from its focus on identifying and comparing extra-literary spaces to their literary counterparts. However, even the more elaborate studies of space disregard its status as a narrative element, focusing instead on its relation to the social, historical, geographical, political, and cultural context in which the narrative itself is produced and/or circulated.

\section{Natural spaces: feminist approaches}

Two key foci can be identified within feminist criticism of fairy tales, one external, the other internal. The first deals with socio-historical and cultural circumstances in which fairy tales are created and disseminated, the (often marginalised) role of women in the creation and dissemination of tales, the processes whereby some tales become part of the canon while others are marginalised, and those in which popular tales are inscribed with various (patriarchal) ideologies. The internal focus shifts from the production of tales to the tales themselves; specifically, it deals with representation of gender, sexuality, and gender roles in fairy tales. While not extensively studied within this approach, narrative spaces are read through the lens of gender; in other words, individual spaces are primarily viewed in terms of their relationship to characters as male or female.

For the most part, feminist criticism of fairy tales grew out of the so-called second wave of the feminist movement in the USA. Although several early feminists such as Simone de Beauvoir and Betty Friedan mention fairy tales in their writing, the beginning of feminist fairy-tale scholarship is commonly associated with the 1970s, when key texts such as Alison Lurie's "Fairy Tale Liberation" (1970), Kay Stone's "Things Walt Disney Never Told Us" (1975), and Sandra Gilbert and Susan Gubar's The Madwoman in the Attic (1979) were published. Lurie's praise of fairy tales as recommended reading for children that will "prepare [them] for women's liberation" (1970: [s.p.]) provided a strong impetus for feminist scholarship. Marcia Lieberman (1972) in response proposed a contrasting view of fairy tales as a means of perpetuating patriarchal ideology and criticised Lurie's examples of supposedly 
progressive tales for being cherry-picked from the corpus of lesser-known stories, which, Lieberman claims, have little to no influence on the popular imagination.

Building on Lieberman's notion of fairy tales as a patriarchal tool, much of subsequent feminist scholarship examines the role of the genre in the processes of socialisation and acculturation, focusing on the representation of gender (roles) in the narratives, often seen as extremely negative, retrograde, and harmful for (young) audiences. Female characters in particular are considered problematic due to their portrayal as "passive heroines in need of rescue $[\ldots]$, insipid victims $[\ldots]$, or $[\ldots]$ willful, spoiled princesses" (Barchers 1990: xi). In addition to popularising the stereotype of "the helpless, hapless heroine" (Yolen 1998: xvii), fairy tales are criticised for (among other things) glorifying beauty, obedience, passivity, sacrifice, and submission to male dominance as the most desirable female traits, demonising older women and female power (Gilbert \& Gubar 2002[1979]: 3-44; Rowe 1979), promoting jealousy and competitiveness among girls, and discouraging female cooperation and solidarity (Mendelson 1997). However, it should be noted that although initial feminist responses criticise fairy tales for being "powerful transmitters of romantic myths", and means of supporting and promoting the patriarchal status quo (Rowe 1979: 239), they are by no means seen as the sole source of the problem. As Kay Stone notes (1985: 139):

It would be simplistic [...] to credit fairy tales with full power as a socializing force, when everything from early nursery rhymes, school texts and other books, television and movies, and personal contacts contribute to our particular system of differential socialization for girls and boys.

Much of (early) feminist criticism of fairy tales is based on a limited sample of popular, canonical narratives (the Perrault/Grimm/Disney versions), with descriptions of the (stereo)typical passive heroine informed by the likes of Snow White, Cinderella, and Sleeping Beauty (Stone 1986: 230; see also Stone 1975). Expanding this corpus to include marginalised tales featuring active, resourceful heroines (brought to the forefront through numerous anthologies such as Lurie's Clever Gretchen and Other Forgotten Folktales or Angela Carter's two Virago Books of Fairy Tales) helped popularise an alternative view of the genre as potentially subversive and liberating. Moreover, acknowledging that individual readers respond and use fairy tales differently destabilises generalisations about their harmful effects (cf. Stone 1985).

Feminist scholarship of fairy tales is inextricably linked with so-called feminist fairy tales, which - like the critical texts themselves - are created in response to what is perceived as the patriarchal dominant. The rather broad term is typically used to designate several things: traditional marginalised stories about independent, active 
heroines (as featured in the previously mentioned anthologies); re-imaginings of traditional tales which typically include reversals of gender roles, positive gender representation, and unconventional endings; and original tales, which often substitute the (stereo)typical romance plot with a tale of female development and maturation (MacDonald 1982: 18; Stone 1986: 231). The latter gained particular momentum in the $1970 \mathrm{~s}$ with the publication of arguably the most significant collections of feminist fairy tales: Anne Sexton's Transformations and Angela Carter's The Bloody Chamber, first published in 1971 and 1979 respectively. Research on (contemporary) feminist fairy tales is mostly concerned with the representation of gender and sexuality, as well as the ways in which the new narratives challenge their "traditional" counterparts (see, for instance, Bacchilega 1997; Benson 2008; Lau 2015; Schanoes 2014). ${ }^{29}$

In addition to fairy tales, fairy-tale scholarship itself has also been the subject of feminist scrutiny, as basic research tools such as the tale type and motif indices have been criticised for being overly male-centric (cf. Lundell 1986). Moreover, feminist critics have engaged in the process of re-examining and re-writing the history of the fairy tale, traditionally dominated by male writers and collectors, by shifting the focus to previously neglected and supressed female voices (e.g. Harries 2003[2001]; Warner 1995). ${ }^{30}$ Scholarship on the editorial history of the KHM provides valuable insight into the processes of assimilating female voices, and shaping fairy tales into vehicles for promoting specific gender traits and roles. Of special note in this respect is Ruth Bottigheimer's (1987) examination of how the various alterations introduced by the Grimms throughout the seven editions of their collection worked towards silencing female voices in the tales and promoting patriarchal views, as well as specific, narrowly defined models of gender identity and behaviour.

Bottigheimer's work is notable for the present discussion because its wider discussion on gender in the Grimms' tales also addresses spatial issues. Specifically, the author offers a gendered perspective on the relationships between characters and their evironment, arguing that the function and portrayal of individual spaces depends to a significant degree on the gender of the characters who interact with them. Thus, various acquatic spaces such as wells, springs, or brooks, typically have positive connotations for female characters, but serve as sources of danger for male characters (Bottigheimer 1987: 29-30). While the forest frequently figures as a site of physical and social isolation for both genders, it typically becomes "a prison" for

29 For a discussion on how feminist scholarship influenced retellings of fairy tales, see Joosen (2011: 49-121)

30 Although he is not a feminist scholar, Heinz Rölleke's (1985; 1986[1975]) extensive research on the editorial history of the KHM uncovered a multitude of female contributions and influences on the collection. 
female characters, who often spend long periods of time hiding in treetops; in contrast, male characters freely move through wooded realms, which provide them with shelter in times of peril (ibid.: 91). The concrete location of individual spatial elements is also important: trees, for instance, are helpful when found in the vicinity of female protagonists' houses, as in "Cinderella" (KHM 21, ATU 510A) or "OneEye, Two-Eyes, and Three-Eyes" (KHM 130, ATU 511), but serve as sites of isolation, waiting, and even imprisonment when found in the forest or wilderness, as in "The Virgin Mary's Child" (KHM 3, ATU 710; ibid.: 102-103). Although not primarily concerned with spatial issues, Bottigheimer demonstrates that individual fairy-tale spaces do not have fixed attributes, but change depending on the story and characters. However, she is primarily interested in spaces as natural features and expressions of natural power, which also accounts for her interest in a few select locations. The focus on wells, ponds, and springs, for example, stems from their function as containers of water, a natural element commonly associated with women and contrasted with the presumably masculine element of fire (ibid.: 24-35). Similarly, forests and trees are viewed less as spaces and more as natural features. Some spaces, such as larger bodies of water (ocean, river, etc.) appear to be genderneutral, which is remarked on but not explained (ibid.: 31, n.16).

The main point of contention when it comes to feminist scholarship of fairy tales has been its almost exclusive focus on the Western canon (especially Germany, France, the UK, and North America; Haase 2004: 29). These issues have been addressed with increased frequency in recent years, which have seen the publication of numerous studies that explore non-Western fairy tales and provide non-Western perspectives (e.g. Fraser 2017; Mackintosh 2004; Murai 2015; Odber de Baubeta 2004; Teverson 2019; Zinn 2000; Zlatar 2007). What is more, some scholars (most notably, Haase 2004) call for a revitalisation of reception studies within feminist scholarship, proposing more research on how female readers interpret and interact with fairy tales, and what kind of impact (if any) these narratives have on their lives.

Despite the expansion of perspectives and research corpora, the engagement of feminist scholarship with spatial issues remains limited. When studied, fairy-tale space is examined primarily through its relationship to (male/female) characters, whose gender determines whether a given space will be safe or threatening, a source of help or a site of isolation. Furthermore, based on their relationship to characters, individual spaces are seen as more "masculine" or "feminine" (e.g. various natural spaces).

\section{(Non-)normative spaces: queer/trans and disability studies}

This section presents two fairly nascent areas within fairy-tale research: queer and trans studies, and disability studies. While scholarly interest in representations of 
gender, sexuality, and body is not a novelty, ${ }^{31}$ recent years (especially the 2010s) have seen the emergence of new theoretical and methodological frameworks, and more systematic efforts directed at exploring these issues. ${ }^{32}$ When it comes to space, queer, trans, and disability studies share a perspective similar to that of feminist approaches, in the sense that individual spaces are studied in relation to characters and seen as bearers of (non-)normative values. As with psychoanalytical interpretations which link it to the processes of maturation and individuation, the departure from home is seen as the first step in the process of identity negotiation and self-realisation.

Broadly defined, queer and trans studies focus on forms of subverting and destabilising normative categories of gender and sexuality, which are defined as socially and culturally produced, rather than "natural" (Seifert 2015a: 16). To read a text through a queer lens therefore means to radically decode it by assuming "an oppositional stance toward the dominant" (Sinfield 1994: 67), to read it "against the grain" by focusing on the "signs and meanings neglected or obscured by heteronormative interpretations" (Seifert 2015a: 16). Queer and trans approaches to the fairy tale challenge the traditional view of the genre as heteronormative, which largely stems from its portrayal of heterosexual marriage as the ultimate reward, and its uses for promoting and upholding patriarchal gender roles (ibid.: 17-18). Like feminist studies, with which it shares a number of research interests, queer and trans fairy-tale scholarship deals with both contemporary queer fairy tales and retellings (Hennard Dutheil de la Rochère 2009; Orme 2010), as well as traditional fairy tales (Greenhill 2008; Greenhill \& Anderson-Grégoire 2014; Turner \& Greenhill 2012b; Turner 2015) and their adaptations (Duggan 2013: 43-70; Greenhill 2015; Orme 2015).

Blending the real and the unreal, the fairy tale itself is a queer ${ }^{33}$ genre with the potential to destabilise "our conceptions of what is normal" (Seifert 2015a: 19). The fantastic, unreal realm in particular is recognised as "a queer place" (Turner 2015: 49) which provides liberation from coercive (hetero)normativity and a platform "for fulfilling alternative desires" (ibid.: 46). As such it represents a foil to the normative world the protagonist leaves at the beginning of the story. It is precisely by leaving

31 This is especially true of queer and trans scholarship, anticipated in feminist approaches. The origins of contemporary queer and trans fairy-tale scholarship are traced back to Lewis Seifert's (1996) study of French fairy tales, while early examples of the study of disability in fairy tales include the works of Lüthi (1970), Uther (1981), and Schoon Eberly (1988).

32 The two theoretical and methodological frameworks are sometimes combined (see, for example, Solis 2007).

33 For an overview of the broad range of uses of the term queer, see, for instance, Duggan (2013: 7-8) and Turner \& Greenhill (2012a: 4-5, 10-11). 
the initial, normative space that the protagonist overcomes "social and sexual prohibitions" (Turner 2012: 247), becoming free to explore alternative identities. Seen through that lens, the crossing of spatial boundaries becomes an act of "[t]ranscending the normal" (Turner \& Greenhill 2012a: 6). Discussing the traditional binary that links women with the private, domestic setting and men with the public arena, Pauline Greenhill, Anita Best, and Emilie Anderson-Grégoire (2012) analyse the gender-bending possibilities inscribed in the fairy-tale heroine's departure from home. Margaret Yocom's (2012) analysis of the Grimms' "All Fur" (KHM 65, ATU 510B) and Joy Fairfield's (2012) interpretation of "Princess Mouseskin" (a tale published only in the first edition of the KHM) demonstrate how by refusing to remain within the oppressive domestic environment the heroines of the two tales also reject the confines of gender, class, and even human identity (both girls don animal disguises). While Yocom does not explore the spatial extension of All Fur's bodily transformations and their pronominal reference in more detail (2012: 115), Fairfield highlights the possibility of reading the mouse skin the princess is wrapped in as an enclosed space, a "grotto-esque cavern of the womb" (2012: 235). She also makes a case for the spatialisation of (non-)normativity by stating that the desire of Princess Mouseskin to transform does not stem from her feeling trapped in the wrong body, "but rather from being trapped in the wrong world" (ibid.: 237).

Kay Turner's readings of two Grimms' tales featuring a relationship between young and old women - "Mother Trudy" (KHM 43, ATU 334; 2012) and "Mother Holle" (2015) - emphasise the spatial extension of the opposition between the heteronormative and homonormative, which is manifested as the opposition between the communal parental home and the witch's isolated cottage in the woods in "Mother Trudy" (2012: 249), and between the human, patriarchal, feudal, surface world and the enchanted, feminine, fertile, subterranean world in "Mother Holle" (2015: 52). Moreover, identifying Mother Holle as "nature personified" (ibid.: 57), Turner sees the entire enchanted realm as an extension of her body; thus, when the young protagonist fetches the bread from the oven or shakes the apples from the trees, she "touches [Mother] Holle and is touched by her" (ibid.). However, although she does pay attention to its spatial aspects, Turner is primarily interested in the enchanted realm as a temporally distinct location, ascribing the cross-generational queerness she identifies as the thematic centre of the story to the realm's "highly unusual temporalities" (ibid.: 45). Research on queer fairy-tale characters - most notably old women such as the aforementioned Mother Trudy (Turner 2012) or the witch/wise woman in "The Goose Girl at the Spring" (KHM 179, ATU 923; Goldstein 2012) - highlight the fact that their spatial isolation is often freely chosen rather than forced, and portrayed in positive terms. In fact, these women embrace 
"their marginality, abjection, and private nature [...] tak[ing] secret delight in going it alone in those cottages deep in the woods" (Turner 2012: 246).

Although queer and trans scholarship on fairy tales perceives the enchanted realm as being "characterized by temporal queerness and spatial oddities" (Turner 2015: 45), only its temporal queerness has attracted explicit scholarly attention (Seifert 2015b; Turner 2015). The spatialisation of queerness and importance of spatial transference for the destabilisation of the norm and identity explorations (when recognised at all) are usually mentioned in passing and have so far not been the primary research focus. Furthermore, the research that does acknowledge the spatial component often views it simply as a backdrop for characters' identity negotiations, interpreting all enchanted, non-human spaces as a foil to the normative human space.

Despite the prevalence of disabled characters in fairy tales, the issue of disability has long been overlooked in fairy-tale scholarship. Like narrative space, disability has traditionally been dismissed as a "background [...] a setting for the actions of others, an atmospheric backdrop, an unchanging horizon - one that can be overlooked or ignored" and therefore starts to be "accepted as a universal truth rather than questioned as a cultural perspective" (Franks 2001: 244). Still in its infant stages, the study of disability in fairy tales rejects ableism, i.e. the privileging of nondisabled views and the marginalising of disability, challenging ableist stereotypes that view the disabled as inferior, defined by their disability, which they seek to "overcome". Furthermore, it relies on the social, rather than the medical model of disability, which understands it as social construct and calls for external (social, political, etc.) changes that will facilitate access (Schmiesing 2014: 4-6). Existing research on disability in fairy tales has so far primarily dealt with identifying (and medically diagnosing; Schoon Eberly 1988) disabilities featured in different corpora of fairy tales - primarily the Grimms' (Franks 2001; Schmiesing 2014) and Hans Christian Andersen's tales (Mitchell \& Snyder 2000: 45-57; Yamato 2017; YenikaAgbaw 2011) - and exploring their representation and uses.

Disability studies assume a stance towards the otherworldly similar to that of queer/trans studies, viewing it as a non-normative, disabled space. Ann Schmiesing's reading of the Grimms' "Hans My Hedgehog" (KHM 108, ATU 441) is illustrative of this approach: shunned in the human world, the anthropomorphic hedgehog "thrives in the forest", a liberating and supportive environment that allows him to use his talents to achieve economic success and happiness (2014: 126). In the normative, "socially oppressive environments" of the village and parental home, Hans's otherness is spatially marked: forced to sleep on the floor behind the stove, he is "separated from and beneath others in terms of his physical location and with respect to how others view [...] him" (ibid.). In stark contrast, in the forest he assumes an elevated position on top of a tree which, thanks to the panoramic view it 
provides, allows him to enter into an advantageous bargain with two kings who are lost in the wooded realm.

Particularly striking in Schmiesing's reading of "Hans My Hedgehog" is the observation that Hans's body is viewed as different and "unnatural" only within the normative space of the village, while in the forest it takes on positive connotations and becomes "part of nature" (2014: 127). The viewpoint of disability studies therefore stresses that changes in the external perception of a given character and their own experience have a strong spatial component. Schmiesing offers further examples in her reading of "The Frog King, or Iron Heinrich" (KHM 1, ATU 440), noting that, when transported from the well to the royal castle, the enchanted amphibian finds himself in an environment that considerably hinders his mobility: he has trouble moving around, and needs to be lifted onto the table and carried up the stairs (ibid.: 104). In a movement that is the reverse of Hans's, the frog suddenly becomes "disabled in or by human society" (ibid.: 102) as he is transported from a natural space to a space where his body is decidedly unnatural. In a similar vein, Vivian Yenika-Agbaw's reading of Andersen's "The Little Mermaid" highlights the radical difference in status the titular character undergoes when she moves from her underwater kingdom, where she assumes a dominant position as a member of royalty, to the human world, where "she is reduced to a dominated person" (2011: 99). The spatial transference therefore marks not only a bodily transformation, but also a radical transformation of the perception and evaluation of that same body (ibid.: 100). Lori Yamato further expands the discussion on the "divided or "doubled world" (2017: 297) of Andersen's story as an embodiment of different types of binaries, including child/adult, male/female, and mythical/everyday. The doubling is also translated onto the space of the mermaid's body, which is half sea creature, half human (ibid.: 298).

Like queer/trans scholarship on fairy tales, disability studies recognise the importance of crossing spatial boundaries as a prerequisite for self-realisation. The key instance of transference is therefore the movement "away from a society that sees value and utility only in able-bodiedness" (Schmiesing 2014: 176), which typically coincides with movement into the enchanted "other world". While space underpins the different identity and body transformations that constitute the focus of disability studies, it is rarely explicitly recognised and discussed in greater detail.

\section{Space in focus}

This section presents an overview of fairy-tale scholarship in which narrative space constitutes the primary research focus, rather than a background for explorations of other topics. This direct research on fairy-tale space can be divided into two groups: 1) research on individual fairy-tale locations, such as the well (Heindrichs 1984), the 
inn (Grzywka 2018; Kawan 2012), the castle (Messerli 2019; Wienker-Piepho 2001, 2019), or - most extensively - the forest (Baumgart 1936; Gehrts 1984; Harrison 1992; Maitland 2012; Meder 1988; Ono 2007); ${ }^{34}$ and 2) research on narrative aspects of space and spatial transference. Encompassing several articles and one monograph (Leeuwen 2007), the latter category directly informs the present research and will therefore be examined in more detail.

Dmitry Sergeyevich Likhachev's (2014[1967]) study of the poetics of early Russian literature encompasses, among other genres, the fairy tale, which is discussed in terms of its artistic time and artistic space. For Likhachev, the key feature of fairy-tale space is its "superconductivity", or minimum resistance the material environment presents for the protagonists (2014[1967]: 328). In other words, the space itself never provides obstacles for the protagonists (unless it is manipulated by antagonists), allowing them to move through the fairy-tale world quickly and effortlessly, and cover large distances. The superconductivity of fairytale space also accounts for its other traits, especially its "extreme expansion" (ibid.: 329) and "boundless, endless" nature (ibid.: 330). Intertwined with time, fairy-tale space is also dynamic: it not only "creates an environment for movement" but is itself constantly moving and changing (ibid.: 327). This is why, according to Likhachev, the (traditional) fairy tale does not contain static descriptions; rather, it provides spatial information relevant to the story while developing the action (ibid.: 223). Like the formalists, the author also highlights the role of space in the structural organisation of the fairy tale, as each new episode takes place in a different location. However, Likhachev does not recognise space as an independent narrative element, claiming that its significance and function are inextricably linked to the action. Thus, the significance of the aforementioned superconductivity primarily lies in the fact that it - together with the genre's "quick" time - provides "exceptionally favorable conditions in the fairy tale for the development of action", which unfolds "more easily [...] than in any other genre in folklore" (ibid.: 330). For Likhachev, "this lack of resistance and ease with which everything happens" (ibid.: 331) is crucial for the genre and even precedes magic in terms of significance. While many other scholars list it among the genre's key traits, Likhachev finds magic to be a secondary feature of the fairy tale, a later addition to the narratives introduced in order to justify the ease with which the plot develops. While it might initially seem that the superconductive space presents the genre's key distinguishing feature, its

34 This group also includes entries on individual spaces and types of spatial transference featured in the Enzyklopädie des Märchens (Ranke 1977-2015). Significantly, other reference works, such as The Greenwood Encyclopedia of Folktales and Fairy Tales (Haase 2008b) or The Oxford Companion to Fairy Tales (Zipes 2002[2000]b) do not contain entries on individual spaces or fairy-tale space in general. 
significance is somewhat diminished by the fact that, as the author claims, there is little diversity among the forms of artistic space in the different genres of early Russian literature, and even other artistic forms such as painting or architecture (ibid.: 332). Like Lüthi, Likhachev offers somewhat contradictory observations on space, which is (sometimes implicitly, sometimes explicitly) identified as both dynamic and active, a key ingredient in generating the genre's recognisable features, and a secondary, dependent element which exists only in service to the action and bears (too) much similarity to space in other genres.

Although primarily interested in time in folk narratives, Wilhelm Nicolaisen was among the first to systematically argue for the study of space. However, his contribution to research on spatial issues is by no means limited to the simple acknowledgement of its importance: in his two most important papers on the topic (Nicolaisen 1980, 1988), the author also challenges existing views on the nature of fairy-tale space and its interpretations. Based on his analysis of the first ten stories in Stith Thompson's One Hundred Favorite Folktales, Nicolaisen (1980) highlights the importance of both horizontal (inside/outside) and vertical (up/down) spatial relations, leading him to reject Lüthi's claims about the depthlessness of the fairy tale (as it pertains to three-dimensional environments) and the lack of an external environment as a key component of isolating the protagonist. Of particular importance for the present research is his observation on the limitations of existing strands of scholarships (he specifically mentions Bettelheim) which view space only in symbolic terms. While acknowledging the existence and importance of the symbolic function of fairy-tale spaces, Nicolaisen points out that this is by no means their only function, calling instead for a reading of fairy tales on the "surface level in which forests are forests, gardens are gardens, rooms are rooms, keys are keys, and closed doors hide real secrets" (1980: 16). However, he ultimately gives precedence to time over space, claiming that, since humans are more fascinated by time and its passage, the temporal aspects of the fairy tale inevitably exceed spatial ones in both quantity and "quality of insight" (ibid.: 14; see also Nicolaisen 1988).

The research by Joyce Thomas (1986) lies at the intersection of the two research categories identified in the opening paragraph of this section ("Space in focus"), as it is concerned with both individual spaces and fairy-tale space in general. Like Nicolaisen (1988: 361), Thomas describes the narrative space of the fairy tale as unmappable, identifying the typical setting of the genre as a "timeless, spaceless, quasimythic sphere" (1986: 126). Despite its abstract quality, the author considers it to be an important element of the genre, which forms a physical framework in which the story unfolds, generates atmosphere, and provides "an external, tangible correspondence to things internal and intangible" (ibid.: 127). The latter function suggests that space plays an important role in what Lüthi describes as externalisation, i.e. the process wherein "[e]verything psychological is externalized onto the level of 
actions or objects $[\ldots]$ and is thus made distinctly and impressively manifest" (1986[1947]: 29). Thomas proceeds to analyse what she claims to be "the four most common settings in traditional fairy tales" - namely, "the woods, the castle, the tower, and the hut in the woods" (1986: 127). Relying on Gaston Bachelard's poetic reading of space, Thomas is concerned only with the symbolic properties of the four locations (e.g. the castle as a symbol of royalty and success; ibid.: 129).

Donald Haase discusses fairy-tale spaces in the context of adult memories of childhood war-time trauma, arguing that these recollections use "the imaginative space of the fairy tale" as "an interpretative device and psychological strategy" (2000: 366). Autobiographical accounts of childhood trauma which Haase analyses use fairy-tale landscapes to navigate and interpret their own emotional landscapes, and map their experience of violent physical displacement (ibid.: 364, 373). Even though the author is primarily interested in the symbolic potential of fairy-tale spaces, and their role in the process of creating memories and coping with trauma, rather than the fairy-tale narrative itself, he makes several important observations about the spatial aspects of the fairy tale. Specifically, he challenges traditional views of the genre by stating that the fairy tale is timeless not because of its presumed universality or abstract temporal setting, but because its plot "is not driven or defined by time or temporal considerations" (ibid.: 362). In fact, he claims, the fairy tale shows a distinct "structural disinterest in time" (ibid., original emphasis), a disinterest which does not extend to space. Rather, the fact that the protagonist's separation and isolation (as described by Lüthi) is spatially defined makes space the key driving force of the narrative. Haase also observes that individual fairy-tale spaces are essentially ambiguous, meaning they can take on different roles and attributes, depending on the concrete narrative (ibid.: 363-364).

Especially relevant for the present research is Alfred Messerli's (2005) paper on the key features of spatial representation in European popular fairy tales (collections published between the seventeenth and twentieth centuries, primarily works by Basile and the Grimms). Building on Lüthi's research, Messerli examines three aspects of spatial representation in the European fairy tale: narrative economy, discontinuity, and narrative perspective. The economy of spatial representation is manifested as the tendency of fairy-tale narratives to provide minimal information about space, often reduced to naming a single object or spatial element, and the frugal use of spatial indicators (Messerli 2005: 276). As his example of a scene from the Grimms" "The Frog King" shows, the narrative uses different indirect means such as references to characters and their actions to establish the scope of the space of action (ibid.: 276-277). Spatial information is thus revealed gradually, with the dimensions of narrative space expanding as the story progresses. This expansion is often realised via the protagonist's journey, the portrayal of which also reveals fairytale space as essentially discontinuous, a space "of places and channels, not of space 
itself" (ibid.: 281). Moreover, Messerli notes that fairy-tale space is "simultaneously contractive and expansive" (ibid.: 278), as dimensions of objects and spaces that contain them can magically increase or decrease. Spatial dimensions and especially distances may also be established through references to acoustic signals, light, time, or bodily endurance, or the use of specific linguistic strategies (e.g. iterative use of verbs). Finally, the author explains the importance of perspective for establishing space by comparing two versions of "The Wolf and the Seven Young Kids" (KHM 5, ATU 123): one which features figural narrative perspective and one which provides the perspective of the kids (ibid.: 280-281). The issue of perspective (or rather, focalisation) in fairy tales is given more attention in Messerli's entry on space in the Enzyklopädie des Märchens, which identifies it as zero (narratorial) or limited and subjective internal focalisation (2004: 360; see also Messerli 2019).

Finally, Richard van Leeuwen's monograph (2007) provides an analysis of the journey as a key narrative element in tales featured in The Thousand and One Nights. Leeuwen highlights the importance of boundaries for narrative organisation and the journey as a means of shaping spaces and boundaries, which exists only "through the dynamic process of movement" (2007: 141). The author's most insightful observations concern the relationship between characters and their environment. Although he does not cite Lüthi, Leeuwen reaches a conclusion similar to that of the author of The European Folktale regarding the need to isolate the protagonists by detaching them from their environment. However, as Leeuwen points out, by setting off into the world the protagonist does more than just detach himself from his physical environment (ibid.: 15):

He leaves behind the identity belonging to his role in his society and can adopt various roles and identities in accordance with the spaces which he traverses. He becomes an "unknown" person, on which no specific identity is inscribed, except that of the traveller, the stranger and the "other", a status with both positive and negative connotations.

The journey is therefore identified as a series of changing roles and identities, a process of individual transformation and development. However, Leeuwen's view is mostly character-centric, meaning that while space is recognised as an important plot element, its significance is derived from its role as a setting for and symbol of the characters' development. Thus, spaces are not perceived as being "meaningful in themselves; their significance is determined by their function as the object of journeys, or their relation to the situation of the heroes" (ibid.: 23). In this view, space remains a static, passive background for the action which does not exist independently from the (mobile) characters. 


\section{The present research}

As the preceding overview of literature shows, narrative space has rarely been at the forefront of fairy-tale scholarship. However, this does not mean it has been completely absent from it. On the contrary, space often looms in the background, underpinning many theoretical discussions and interpretations, without being explicitly recognised as a significant narrative element and studied independently. As such, the status of narrative space within fairy-tale scholarship often mirrors the perceived status of narrative space in fairy tales themselves: a background against which the action/scholarly discussion unfolds.

When it is acknowledged, space in fairy tales is predominantly studied as a symbolically potent element of the story. The juxtaposition between the human and the enchanted world is of central importance in this respect, to the extent that the traits and roles of individual spaces are subsumed under the wider human/enchanted frame. The various interpretative approaches regularly view the enchanted world as the "other" of the human world. As such, it can easily be adapted to different theoretical and interpretative discourses, which view the "this world"-"other world" dichotomy as a symbolic representation of whatever binary is central to the individual approach: conscious-unconscious (psychoanalytical approaches), human-nature, male-female (feminist approaches), normative-non-normative (queer/trans approaches), able-bodied-disabled (disability studies), etc. Similarly, the significance of crossing spatial boundaries (primarily the boundary between "this" and the "other" world) is viewed in symbolic and thematic terms, as the beginning of the process of individuation, self-exploration, self-realisation, etc. While symbolic interpretations of space do provide valuable insights, they fail to consider space in its own right, instead viewing it only as a stand-in for something else. Moreover, the interpretation of space often hinges on the understanding of what prompts the departure from home: protagonists must leave in order to become adults (Bettelheim 1991[1976]), to escape the heteronormative or ableist community in which they do not belong (Schmiesing 2014; Turner 2012), to meet a magic helper (Propp 1968[1928]), etc.

Space is not the only fairy-tale element to have traditionally been reduced to its symbolic potential. Recent years have seen an increase in systematic attempts to abandon traditional views of individual story elements - most notably, disability (Schmiesing 2014) and sartorial elements (Do Rozario 2018) - which consider them "only insofar as [they] symbolize[...] something else in the tales" (Schmiesing 2014: 11, original emphasis), in favour of an approach that examines these elements on their own terms and in their own right. Although the need for a similar reorientation in research on fairy-tale space has already been voiced by Nicolaisen (1980), his call to view space as space has not had the desired impact. On the contrary, with the exception of Messerli's work (2004, 2005), even studies in which spatial concerns 
are central tend to explore them in relation to something else (Haase 2000; Thomas 1986), often remaining character- or plot-centric (Leeuwen 2007). Responding to Nicolaisen and following the recent trend in fairy-tale scholarship exemplified in the works of (among others) Schmiesing and Do Rozario, this research constitutes a departure from traditional views of narrative space which treat it "chiefly as symbol or metaphor" (Do Rozario 2018: 1), significant primarily in terms of what it can reveal about the meaning of the story and/or other (extra-)literary elements. It considers narrative space as a concrete rather than symbolic environment, in which characters live, move, and interact, and which is created through different sets of relations. Moreover, it does not look "for hidden truths behind material things and spaces" (Karlsson Marcussen 2016: 47), claiming instead that space is meaningful and significant in and of itself, rather than becoming meaningful through reference to something else. While it summarises and builds on existing findings about fairy tales in general and fairy-tale space in particular, the present research also differs from them in several ways.

The main goal of this research is to explore the narrative space of the fairy tale: its structure and organisation, means of its textual realisation, general traits, and significance for the genre. To achieve this aim, it combines fairy-tale scholarship and narratology (discussed in Chapter 3), specifically narratological textual analysis, which has, to the best of this author's knowledge, not been applied to the study of fairy-tale space. The present research acknowledges the importance of considering socio-historical and other extra-textual elements in the study of narratives, as well as the need to study the spatial extension of the Grimms' fairy tales as a reflection of the social, cultural, political, historical, literary, and physical (geographical) environment which produced the KHM. However, because of its interest in space as a narrative element, it focuses on the text.

While it draws from much of the observations and findings about space discussed above, this research finds its most significant models in the works of Lüthi (1976[1969]a, 1986[1947]) and Messerli (2005, 2019). Lüthi's significance for this dissertation is twofold: on the one hand, his findings about the fairy tale in general, especially its one-dimensionality, economical language, externalisation, and focus on action, are used to explain the representation and function of narrative space in the fairy tale; on the other hand, his comparative, space-centred discussion of the legend and fairy tale provides both an impetus and model for the present examination of potentially genre-specific traits of fairy-tale space. By considering space as an independent narrative element in its own right, this thesis also diverges from Lüthi, who, although implicitly acknowledging the significance of space, explicitly dismisses it as a background element which exists only in relation to characters and is only activated when the plot demands it. Furthermore, this research challenges Lüthi's insistence on distance as the key attribute of the spatial relationship between 
the human world and what he calls the otherworldly. While impossible distances certainly are a staple of many fairy tales, particularly adventure or quest fairy tales, this research points out that not all tales require their protagonists to travel far and wide to come into contact with the otherworldly. Rather than highlight distance, it points to firm boundaries as the principal means of separating the two fairy-tale worlds (Chapters 3 and 4).

The importance of Messerli's $(2005,2019)$ work for the present research stems from the fact that he - like this dissertation - examines space in the fairy tale as a narrative element. However, this research is both thematically more expansive than Messerli's, as it focuses on several aspects of space besides its representation (structure, traits, function), and narrower in terms of its corpus, which consists of the printed texts of the Grimms' fairy tales (Messerli briefly comments on the role of the space of narration and non-verbal elements such as gestures in creating narrative space during oral storytelling; 2005: 275). Messerli's discussion about the key aspects of spatial representation - narrative economy, discontinuity, and narrative perspective - is an important source for Chapters 5 and 6, which take a closer look at each of these aspects and examine their manifestations in the Grimms' narratives. They further expand the discussion on fairy-tale space (which Messerli describes as discontinuous, simultaneously expansive and contractive, and unmappable) to include other traits and narrative strategies (Messerli mentions characters' movement, light and sound, and perspective; 2005). Unlike Messerli, this research adds both a narratological and genre perspective to the study of narrative space.

In its examination of the structure and organisation of narrative space, as well as the means of its textual realisation, the present research combines fairy-tale scholarship with narratology, drawing especially on the works of Katrin Dennerlein (2009) and Marie-Laure Ryan (2014[2009]; Ryan et al. 2016). Existing research on fairy-tale space has dedicated little attention to spatial structure, its focus mostly being on how space and spatial transference participate in structuring the narrative, rather than how space itself is structured and organised. Moreover, discussions of space as a structural element (formal approaches) and the structure of space (narratology) rarely consider its genre-specific features. In contrast, the present research not only asks how space in fairy tales is organised and structured, but also what (if anything) about the way fairy tales organise their narrative space is unique to the genre. The starting point for this aspect of the present research is Lüthi's (1976[1969]a, 1986[1947]) discussion of space as a means of distinguishing between the fairy tale and the legend, and his recognition of genre-specific aspects of spatial organisation. Adopting and expanding on Lüthi's comparative approach, this research examines the spatial organisation of the fairy tale alongside other KHM genres to determine whether any of its traits might be termed genre-specific. As such, 
it asks whether considering space as a possible genre criterion can shed new light on and promote our understanding of the fairy-tale genre.

Spatial transference has similarly (primarily within the framework of formal approaches) been discussed in terms of its significance for the structural organisation of the fairy-tale narrative. However, while, as Propp (1968[1928]), Jason (1977a), and others have demonstrated, space in fairy tales does help delineate individual episodes, with spatial transference providing a connection between them, a similar claim can be made for many other, generically diverse, narratives. Unlike formal approaches, the present research also examines the unique aspects and role of spatial transference in fairy tales (as opposed to other narrative genres), recognising it as a key precondition for the encounter between the human and the "otherworldly", which, in turn, is seen as a distinguishing feature of the genre (Chapters 3 and 4). Furthermore, the spaces among which fairy-tale characters move, as well as the central binary between the human world and the world of magical beings, are understood as physical spaces/boundaries, rather than carriers of symbolic meanings.

Many existing studies maintain that both the significance and presence of space in fairy tales is dependent on and exhausted in their relationship to the characters. Lüthi (1986[1947]), for example, states that individual spaces exist only in terms of their usefulness to the plot, i.e. in relation to the protagonist: once he or she leaves a given space behind, it simply disappears and is never mentioned again. However, findings such as Bottigheimer's (1987) observations about how different spaces "respond" differently to characters depending on their gender, with the same space serving as a sanctuary for a male and a prison for a female protagonist, indicate that the relationship between space and characters may not be entirely one-sided, with passive space merely foregrounding the active characters. The notion that different characters may elicit different "responses" from the same space also confirms what Haase (2000) recognises as the ambivalence of fairy-tale space, i.e. the lack of fixed attributes that can unequivocally be ascribed to a single space. This type of mutability points to the possibility of viewing the relationship between space and characters in terms of a more complex interplay, one in which space is accorded a more active role (cf. Lefebvre 1991[1974]). Chapter 6 of this thesis explores this possibility and asks whether space is not only shaped by characters but also, in turn, shapes them.

The novelty of the research presented in this dissertation comes from the combination of its focus on the heretofore largely neglected topic of narrative space in fairy tales, the specific aspects of the topic it studies, and the theoretical and methodological framework in which it is situated. The research brings together knowledge produced within fairy-tale scholarship and narratological tools to examine the structure and qualities of fairy-tale space, as well as the means of its textual realisation and significance for the fairy-tale genre. While widespread views 
of the genre give almost exclusive precedence to action, claiming that what happens comes at the expense of everything else, this research draws attention to the spatial parameters of that action, suggesting that it is not only what happens that matters, but also where it happens. 


\section{Spatial Structure in Fairy Tales}

The aim of this chapter is to examine the structure of space in fairy tales; specifically, it seeks to identify individual spatial units and their organisation into spatial categories and networks with expanding scopes. It asks how individual spatial units such as rooms, roads, or caves are connected into wider spatial categories such as frames or storyworlds (see below), and whether there is anything about these units and their connections that may be unique to the fairy-tale genre. Since this topic has been mostly overlooked within fairy-tale scholarship, the present research turns to narratology, which has dedicated considerable attention to various aspects of narrative space, including its structure. Of special importance for the present discussion is the work of Marie-Laure Ryan, who has summarised much existing research in her integrated model of the structure of space (2014[2009]; Ryan et al. 2016).

The chapter begins with a brief overview of research on narrative space, both within and outside narratology. Since detailed literature reviews are available elsewhere (see, for instance, Brković 2013; Dennerlein 2009: 13-47, 210-217), this section will focus on those authors who are relevant for the present research in general and the present chapter in particular, specifically Mikhail Bakhtin, Juri Lotman, Jan Joost van Baak, Seymour Chatman, Mieke Bal, Gabriel Zoran, Ruth Ronen, and Katrin Dennerlein. The overview is followed by an exploration of the five categories of space encompassed by Ryan's model: narrative frame, setting, story space, storyworld, and narrative universe (2014[2009]; Ryan et al. 2016). The chapter engages with Ryan's model on two levels: first, it explores its individual categories by discussing them within the wider framework of narrative research and applying them to the first tale in the KHM, "The Frog King, or Iron Heinrich", which has already been the subject of space-oriented research (cf. Messerli 2005, 2019). Second, it adapts Ryan's model - applicable to different types of narratives across genres - to the study of the spatial structure of the fairy tale by adding to it a new, overarching category of the domain (see e.g. Ekman 2013), which encompasses spaces governed by a specific set of natural laws. Unlike Ryan's categories, the domain provides the basis for distinguishing individual KHM genres. To determine whether anything about the spatial structure of the fairy tale - a genre encompassing 
two distinct domains - is genre-specific, the present research compares it with those KHM genres that consist of only one domain: the animal tale, the formula tale, the folk tale, the humorous tale or Schwank, and the formula tale. The final part of the chapter examines the relationship between the two fairy-tale domains in light of Lüthi's observations about the necessity to keep the human world of the fairy tale and the "otherworldly" physically separated (1986[1947]: 10). Specifically, it asks how this separation is spatially realised and whether it is always manifested as large distances inserted between the human and the "other" world.

\section{Studying space in narratives}

This section provides an overview of key authors and ideas connected to the study of space in literature. The first part presents authors working outside narratology, who abandoned the older, mimetic interpretation of narrative space as a reproduction of extra-literary reality in favour of one that recognises it as an important factor in the cultural construction of reality, thus largely anticipating the spatial turn (Brković 2013: 127). The second part focuses on narratologists whose concepts will be utilised in the section which examines the individual categories of space. These include Chatman (setting, story space, discourse space), Bal (frame), Zoran (spatial unit, spatial complex, total space), Ronen (frame, setting, story space), and Dennerlein (object region, event region, area of movement, setting, narrated world). The different strands of (narratological) research on narrative space, which highlight its different aspects, are usefully brought together into an integrated spatial model by Ryan.

A considerable stimulus for the study of space came from researchers working outside narratology. Perhaps the most influential among them is Mikhail Bakhtin, whose concept of the chronotope (2011[1937]) - literally "time-place" - embodies the essential interdependence and inseparability of time and space. Bakhtin defines the chronotope as "the intrinsic connectedness of temporal and spatial relationships that are artistically expressed in literature", and brought together in "one carefully thought-out, concrete whole" (2011[1937]: 84). Through his analysis of a wide range of genres, authors, and literary periods, Bakhtin identifies a series of chronotopes such as the meeting, road, threshold, provincial town, nature, and castle; however, he claims, the unity of time and space finds its clearest expression in "the chronotope of the road ('the open road')" (ibid.: 98). Despite its wide application both within and outside the study of narratives, ${ }^{35}$ the concept of the chronotope has been criticised for a lack of precision and failure to distinguish between different levels of

35 For more recent reflections on and applications of Bakhtin's theory, see, among others, Bemong et al. (2010), and Steinby \& Klapuri (2013). 
text (Gomel 2014: 28), as well as its privileging of time, which the author explicitly identifies as its "dominant principle" (Bakhtin 2011[1937]: 86; cf. Holquist 2002[1990]). While the present research does not utilise the concept of the chronotope in its exploration of space and spatial transference in fairy tales, it does acknowledge the interconnectedness of time and space. Moreover, Bakhtin's theory has found its expression in the models of spatial structure, most explicitly in Zoran's (1984) concept of the chronotopic level in narratives (see below).

In Juri Lotman's (1977[1970]) language-based model, space - defined as a set of spatial relations between individual objects - presents an essential constitutive element of the verbal work of art. Lotman was among the first to highlight the importance of spatial concepts and relations (high/low, left/right, open/closed, etc.) for our perception and organisation of the world around us, noting that we often attach non-spatial, metaphorical meanings to them, such as good/bad, own/other's, mortal/immortal, etc. (1977[1970]: 218) ${ }^{36} \mathrm{He}$ also demonstrated how different cultural and ideological values and meanings are inscribed onto space (cf. 1990: 123-204). In his discussion of spatial composition in select works of Russian literature, Lotman highlights the importance of the boundary, which he considers to be "the most important topological feature of space" (1977[1970]: 229). Consequently, boundary-crossing is seen as a precondition for events, with individual episodes consisting of "the crossing of the basic topological border in the plot's spatial structure" (ibid.: 238), as well as narration in general. According to Lotman, an important feature of the protagonist is his or her ability to "cross the boundaries of prohibitions in a way that others cannot", to "do what others cannot, namely to cross the structural boundaries of cultural space" (1990: 151). In his later works, he explores the importance of the boundary as a division between semantically different areas, such as ours/theirs, living/dead, safe/hostile, harmonious/chaotic, etc. (ibid.: 131). The present research builds on Lotman's insistence on the importance of boundaries and boundary-crossing (Chapter 4).

Lotman's ideas were taken up and further explored by (among others) Jan Joost van Baak, whose semantic analysis of space in I. E. Babel's short stories largely focuses on the "cultural and affective values, moral and ideological oppositions" inscribed and projected onto space (1983: 37). At the forefront of his study, which examines the relationship between space and characters, story, time, and perspective, is cultural space, defined as "any property or manifestation of space that can be anthropologically meaningful and as such receive semiotic value" (ibid.). Of special interest for the present research are Baak's sporadic but insightful musings on the

36 The use of spatial concepts to convey non-spatial meanings is also (albeit from a purely linguistic point of view) studied by George Lakoff and Mark Johnson in their influential Metaphors We Live By (2003[1980]). 
fairy tale, featured in discussions on the opposition between the mobile and the passive hero (ibid.: 96), as well as the inside (the warm, nourishing, safe house) and the outside (the hostile, unknown world; ibid.: 47-48, 61-70).

These early explorations of spatial issues did not (immediately) have an impact on narratology, which was long focused on the temporal properties of narratives. Guided by the understanding of narrative as "the language structure that has temporality as its ultimate referent" (Ricoeur 1980: 169, emphasis added), the founders and early proponents of narratology paid little attention to spatial issues. Some, like Roland Barthes (1975[1966]) or Gérard Genette, ${ }^{37}$ completely overlook them or mention them only in passing, while others explicitly dismiss space as "less essential" compared to other narrative elements such as characters or events (Toolan 2001[1988]: 91). This points to a trend similar to the one identified within fairy-tale scholarship in the previous chapter: namely, space is not studied in its own right, but in relation to other aspects of the narrative, especially characters, events, and focalisation (cf. Rimmon-Kenan 1983; Stanzel 1984[1979]).

However, some early narratologists do consider space in their work: most notably Seymour Chatman (1978), who devises the terms story space and discourse space as spatial equivalents of sorts to story time and discourse time (see below), and Mieke Bal (2017[1985]). Bal's Narratology discusses three levels of narrative: text (medium), fabula (narrative elements), and story (the ordering of the elements). Spatial issues - specifically, description (text), location (place; fabula), and space (story) - are discussed on each level. Space, which encompasses "the specific look and feel" of a particular place (Bal 2017[1985]: 152) is again linked to focalisation. Furthermore, Bal distinguishes between frame-space, which is the physical surrounding of the perceiving character (ibid.: 125), and thematised space (space as the object of narration; ibid.: 139), as well as between steady and dynamically functioning space (ibid.: 127). With the exception of the concept of thematised space, Bal's study of space remains largely character-oriented. The discussion on location - understood simply as "where things happen" (ibid.: 182) - highlights the importance of spatial relations, especially oppositions (e.g. inside/outside), which are (following Lotman's model) studied less for their physical and spatial properties, and more as bearers of various symbolic and metaphorical meanings.

With the exception of Baak's monograph (1983), early research on space in narratives rarely focuses exclusively on spatial issues. Rather, space is examined in relation to other narrative elements such as characters or focalisation, its explorations embedded within wider discussions of topics such as the structure of a literary text

37 While observing that "written narrative exists in space and as space", Genette focuses primarily on temporal aspects of the narrative, which he finds "to some extent conditional or instrumental" (1983[1972]: 34). 
(Lotman) or the history of the novel (Bakhtin). The 1980s saw a gradual change in this trend, with the publication of Baak's study, and articles by Gabriel Zoran (one of the first explorations of the structure of narrative space; 1984) and Ruth Ronen (1986). For Zoran, the key difference between narrative time and space stems from the fact that the former always corresponds to some degree to the readers' "real-life" experience of time, while the latter "does not stand in any kind of correlation with the space of the world" (1984: 312). Thus, narrative space does not exist autonomously but is linguistically produced and inextricably linked with time. As such, it is the result of a complex process of transformation which turns the complete and simultaneously existing space of the world into a temporally arranged series of information which can never convey the "real-world" spatial object in its entirety (ibid.: 313). Zoran examines the structure of narrative space on both the vertical and the horizontal level. On the vertical axis, he distinguishes between three levels of structuring space: 1) the topographical level, which encompasses individual, separate, static units of space; 2) the Bakhtin-inspired chronotopic level, generated by connecting individual spatial units via events and movements, which unfold along the spatial and temporal axes; and 3) the textual level, which encompasses "the structure imposed on space by the fact that it is signified within the verbal text" (ibid.: 315). The three levels exist and are perceived simultaneously (ibid.: 316). The horizontal axis, which encompasses individual parts of space, includes the spatially continuous and clearly demarcated spatial units, which are combined to create the spatial complex (ibid.: 322-323). Complemented with "spatial information which exists beyond the boundaries of the actually presented space", the spatial complex generates the total space (ibid.: 329). The scope and concrete manifestation of each category differs depending on the vertical level.

The focus of Ronen's (1986) research is on the relationship between categories of the spatial construct - primarily frames and settings - and their linguistic manifestations. Despite her understanding of space as a linguistically derived, semantic construct, she claims that spatial components "cannot be identified with specific textual expressions", but are rather "the products of the integration of dynamic bodies of spatial information" (Ronen 1986: 421). As Ronen understands them, the main difference between frames and settings lies in their (non)actualisation: thus, while the frame is both "the actual and potential surrounding of fictional characters, objects and places" (ibid.), the setting refers only to their actual and immediate surroundings (ibid.: 423). Frames can be expressed via direct or indirect identification, and are classified according to their degree of immediacy (immediate, secondary, inaccessible, spatio-temporally distant, or generalised space) and factuality (hypothetical, non-factual, or counterfactual), as well as their (physical) properties such as size, shape, colour, material, function, or boundaries. Individual frames, which typically correspond to individual locations, are related to 
each other following the logic of what Ronen terms the topographical order ("an inherent logic of space"; ibid.: 435), which can rely on containment, distance/proximity, or similarity/opposition. Setting, on the other hand, is manifested as individual locations which exist independently of narrative events. Unlike frames, which are constantly re-established, the setting does not have to be re-affirmed following its initial establishment. Neither the frame nor the setting need to be explicitly identified but are often inferred from the situations or characters. Ronen also mentions (but does not elaborate on) the category of story space (ibid.: 425).

The stimulus for what might be termed a spatial turn in narratology (Buchholz \& Jahn 2005: 551) comes from several sources: phenomenological research (e.g. Bachelard 1994[1957]), which highlights the human experience of space; the theory of possible worlds (cf. Ronen 1994); cognitive research on readers' reception of the different aspects of narrative, including the creation of mental models of space (Herman 2002, 2009; Ryan 1991, 2003; Walsh 2017); and geography, which is becoming more closely linked with narrative research (Prince even speaks of a "geographical narratology"; 2018a: 176; see also Ryan et al. 2016). For the present research, of special importance among contemporary researchers on space in narrative are Dennerlein (2009), whose monograph in itself constitutes a proposal for a narratology of space, and Ryan (2014[2009]), whose categories of space are used as a model for studying the spatial structure of the fairy tale in the following section.

Criticising existing research on space in narrative for mostly producing thematic readings and often failing to define the basic terminology, Dennerlein proposes to lay the groundwork for a narratology of space by describing the means of its (linguistic, textual) construction as well as its constitutive elements, and developing the analytical tools necessary for its study. At the centre of Dennerlein's interdisciplinary research is the "concrete space of the narrated world" (2009: 48), conceptualised as a physical, three-dimensional container with a clearly delineated inside and outside, allowing characters to freely move into and out of it (ibid.: 71). Individual spaces simultaneously encompass smaller spaces and participate in wider spaces (e.g. the space of the house encompasses the smaller spaces of individual rooms, while simultaneously belonging to more expansive spaces such as the street, neighbourhood, city, etc.; ibid.: 60, 68). The author distinguishes between object, event, and movement regions, thus highlighting that even individual objects can function as concrete spaces if characters or other objects can be situated within them. She also discusses direct and indirect means by which space in narrative is constructed, and highlights the importance of perception. Relying on a communicative text model, Dennerlein points out that the totality of space in narrative is the result of an interplay of the structure of space as related on the story level, the spatial information conveyed on the discourse level, and the input from 
readers who continuously fill in the narrative "gaps", creating their own mental model of space. While describing space as the physical environment of events, Dennerlein challenges the space-as-background view by suggesting that events change the surroundings in which they unfold (ibid.: 122-123). In addition to sharing this view, the present research uses Dennerlein's findings regarding the means of establishing narrative space in its exploration of the different strategies used to convey spatial information presented in Chapter 5.

While all the narratologists discussed above examine spatial structure and outline different categories for its classification, the present research (as previously mentioned) uses the model proposed by Ryan (2014[2009]; Ryan et al. 2016) as its starting point for exploring the structure of fairy-tale space. Ryan's model builds and expands on existing research (save Dennerlein), providing a comprehensive, integrated framework for studying the different layers and categories of narrative space.

\section{Categories of space}

The narratological model of space proposed by Ryan (2014[2009]) consists of five categories - the frame, setting, story space, storyworld, and narrative universe - and three levels of space. Reminiscent of Zoran's (1984) division of the vertical spatial axis into three layers, Ryan's levels include the following: 1) the topographical level, which encompasses individual locations. On this level, individual spaces primarily function as static locations and containers of events; 2) the chronotopic level, on which individual spaces are linked into a wider spatial network via movement; and 3 ) the symbolic level, on which space is divided into distinct areas imbued with different values (Ryan et al. 2016: 20-23). The five-part spatial model described below primarily encompasses the topographical and chronotopic level. Since the present research focuses on the traits of individual spaces rather than their symbolic meanings, it does not consider the symbolic level.

This section examines the individual parts of Ryan's model separately. Each category is discussed within the wider framework of narrative research (specifically, in relation to similar concepts proposed by Chatman, Bal, Zoran, Ronen, and Dennerlein) and applied to the Grimms' "The Frog King", the story of a spoiled princess who promises to play host to an enchanted frog if he retrieves her golden ball from the bottom of the well. Once she gets what she wants, the princess has no intention of keeping her word, but is forced to do so by her father. She unwillingly admits the frog into the castle, allows him to eat from her plate, and even takes him up to her bedroom. However, when he demands to sleep in her bed, she becomes furious and flings him against the wall. The frog is instantly transformed into a handsome young king, who marries the princess and takes her to his kingdom. 
Driving their carriage is the king's faithful servant Heinrich, who was so distraught by his master's fate that he had iron rings placed around his heart to prevent it from bursting from sadness.

\section{Spatial frames}

The first category in Ryan's model is defined as the immediate surroundings of characters and events, "the various locations shown by the narrative discourse" (2014[2009]: 797). As "shifting scenes of action", spatial frames "may flow into each other" and are organised hierarchically (ibid.). For instance, the spatial frame of an individual room is a subsection within the larger spatial frame of the house, which, in turn, participates in even wider frames such as the street, neighbourhood, or town. The shift between frames can occur abruptly (one frame is simply substituted with another) or be prompted by characters' movements.

The term frame is also used by Bal (2017[1985]) and Ronen (1986). However, Ryan's understanding of the concept is closer to Ronen's definition of setting, since Ronen's frames do not necessarily function as immediate surroundings for characters and events, but only possess the potential to do so. Only an actualised frame - i.e. one that provides an "actual immediate surrounding of an object, a character or an event" (Ronen 1986: 423, original emphasis) - constitutes a setting. For Bal, the frame is the surroundings of the perceiving character, "the space in which the character is situated, or is precisely not situated" (2017[1985]: 125). Ryan's frame is also comparable to Zoran's concept of spatial units, differently manifested on the three narrative levels: on the static topographical level, spatial units become place, clearly demarcated points in space; on the chronotopic level, they are zones of actions defined by the scope of the action, rather than spatial parameters; finally, on the textual level, they are manifested as field of vision, which can encompass any spatial unit and is essentially the "here" of the text (1984: 323-324). Dennerlein criticises Bal's, Zoran's, and Ronen's concept for being imprecise (they do not provide specific criteria for defining the proposed categories) or too reliant on everyday concepts of space (2009: 120-121), proposing instead the terms object region, event region (spatial component of the narrated events), and areas of movement (event regions connected by characters' movement).

Before turning our attention to "The Frog King", it is important to consider one aspect of spatial frames which is often overlooked (Dennerlein being a notable exception): objects and bodies. Ryan notes that frames are "filled with individual things, and [...] defined by the set of objects that they contain" (Ryan et al. 2016: 24); but what about the objects contained within those frames and the bodies they provide the physical surrounding for? Can they be considered frames in their own right? If we - as Zoran does - ascribe to space the characteristics of "volume, 
extension, and three-dimensionality" (1984: 312), then the various bags and baskets, buckets and bottles, boxes and coffins, and even eggs and walnuts found in the Grimms' tales can be considered spaces. However, there is a considerable difference between the space of an object and an object in space. First of all, this is in large part a matter of perspective and embeddedness in a particular environment. As Manfred Jahn explains: "A fishbowl is an object from our human point of view, but to the goldfish it is a space; similarly, a house is an object in a larger environment (a district, a city), but to its inhabitants it is a space to move or be in" (2017: N6.2.). Turning to examples from the Grimms' collection, a raven's egg in "The Little Hamster from the Water" (KHM 191, ATU 329) is introduced to the story as an object, but quickly becomes a space when the protagonist finds himself magically enclosed inside it. Furthermore, the difference between an object as container (e.g. a bag filled with precious stones) and an object as space is largely predicated on action (Dennerlein 2009: 69). Thus, objects can become spaces when they become sites of action, i.e. when characters are positioned within them. Dennerlein explicitly acknowledges the importance of objects by including in her classification of spatial structure the concept of object region (Objektregion), defined as an area which includes not only the location of the object and the physical space it occupies, but also the area in which interactions with that object unfold (ibid.: 124). For example, the object region of a table includes both the physical space occupied by the table and the area around it used while performing various table-centred activities, such as sitting at or setting the table.

The reason for this lengthy aside is that fairy tales challenge our notion of what can serve as an environment for the action, turning both bodies and objects into potential spatial frames. An especially interesting example in this respect are tales of the ATU 302, The Ogre's (Devil's) Heart in the Egg type, in which animal bodies and objects are intricately enclosed within each other like Russian dolls. In the Grimms' "The Crystal Ball" (KHM 197, ATU 552, 518, 302), the wizard hides the titular object (the source of his power) inside an egg, carried by a firebird, which is inside a wild bison. Moreover, the fact that bodies can be enlarged and contracted to unimaginable extremes creates additional possibilities for exploring their spatial potential. Thus, miniature characters like Thumbling ("Thumbling", KHM 37, ATU 700; "Thumbling's Travels", KHM 45, ATU 700) can move within unexpected spaces such as a horse's ear, a snail shell, or a wolf's stomach.

The action in the Grimms" "The Frog King" takes place within two main frames: the forest and the castle. Each of them encompasses several sub-frames: within the forest, the linden tree and edge of the well create a sub-frame in which the princess rests, plays, loses her ball, and meets the titular amphibian; the actions of the frog (coming up to the surface, diving to the bottom of the well to retrieve the ball) are framed by the sub-frame of the well. The relationship between the two sub-frames is 
indicative of the "flow" Ryan mentions (2014[2009]: 797), as the frog easily moves between them by simply sticking his head out of the water. After the princess runs away and the disappointed frog jumps back into the well, the frame shifts to the castle. The frame of the castle encompasses the following: the entrance to the castle, where the frog reminds the princess of her promise; what is presumably the dining room or hall, where the princess sits and eats with her father (and later the frog); the unidentified stairs the princess climbs to get to her bedroom; and the princess's sleeping quarters, where the transformation from frog to prince takes place. The reference to the princess following her father's wishes and accepting the prince as her "dear companion and husband" (Grimm 2003[1857]: 4) suggests at least one more unidentified sub-frame of the castle in which paternal blessing is granted and wedding wows are exchanged. Finally, the coach which takes the newlyweds to the prince's kingdom also serves as a (mobile) frame for the interactions between the prince and his faithful servant.

The majority of the frames are connected by the princess's movements, generating the chronotopic level of space. The text mentions her going into the forest to play with her ball and later running back home. Inside the castle, she connects the individual sub-frames by twice going to the door, then returning to the table with the frog at her heels, and finally carrying the frog upstairs. After she answers the door for the first time, the frame abruptly shifts to the dining room: "Da warf sie die Thür hastig zu, setzte sie wieder an den Tisch, und war ihr ganz angst [She quickly slammed the door, sat at the table again, and was in a state of fright]" (cf. Messerli 2005: 255).$^{38}$ In the final shift between spatial frames, the newlyweds climb into the carriage (the actual movement from the bedroom to the castle entrance is not mentioned) and drive away towards their new home.

\section{Setting}

Unlike spatial frames limited to individual segments of the story, the second category in Ryan's model - the setting - encompasses the narrative in its entirety. Traditional definitions often refer to it as the "when" and the "where" of the action (Mays 2017[1973]: 284), for which it provides a background without influencing it in any way (Prince 1982: 73-74). It is often viewed only through its relation to the characters (Wellek \& Warren 1956[1948]: 229); Chatman, for instance, explicitly describes the relationship between characters and setting (the "existents" of the story) as one in which the latter serves to set off the former (1978: 138-139).

38 The English translation adds an explicit reference to the movement which is only implied in the German original: "she quickly slammed the door and went back to the table in a state of fright" (Grimm 2003[1857]: 3, emphasis added). 
Furthermore, almost anything that is not an action or event can become part of the setting, including objects and non-essential "background" characters. In addition to its background function, Chatman ascribes setting a symbolic meaning and role in establishing characters and/or narrative atmosphere (ibid.: 142-145).

Ryan's definition not only dismisses references to setting as a background, but also defines the "where" and the "when" in more concrete terms, as "the general socio-historico-geographical environment in which the action takes place" (2014[2009]: 798). This is reminiscent of Meyer Howard Abrams's definition, which lists the "general locale, historical time, and social circumstances" of the action as key components of the setting (1999[1957]: 284). However, Abrams also uses the term in reference to the physical location of individual episodes or scenes (ibid.), evoking the understanding of the concept espoused in Ronen's immediate surrounding of objects, characters, and events (1986: 423), and Dennerlein's special event regions in which the action takes place (2009: 127).

As numerous definitions of the genre point out, the setting of the fairy tale is temporally and spatially abstract - the proverbial "once upon a time in a land far, far away". "The Frog King", with its unspecified, almost mythical "olden times, when wishing still helped" (Grimm 2003[1857]: 2) and unlocalised space ( $a$ kingdom, $a$ forest), is no exception. In terms of social circumstances, the story portrays the opulent world of the royal court. Other fairy tales in the Grimms' collection focus on the opposite end of the social ladder, featuring (among others) impoverished fishermen and woodcutters, farmers, and discharged soldiers. The abstract spatiotemporal framework is shared not only by all the Grimms' fairy tales, but also the majority of other tales, which typically open with Es war (einmal) (once/upon a time) and make only unspecified references to their spatial environment (see Chapter 6).

\section{Story space}

Defined as "the space relevant to the plot, as mapped by the actions and thoughts of the characters" (Ryan 2014[2009]: 798), story space consists of all spatial frames, as well as the locations the narrative mentions but does not show. Encompassing both the spaces which are settings of events and those that are not, story space consists of every piece of spatial information explicitly provided by the narrative. This partly overlaps with Ronen's use of the term as the sum of all the settings (1986: 429). However, unlike Ryan, Ronen excludes unactualised frames (i.e. those where the action does not take place) from story space (ibid.: 425). Ryan's use of the term corresponds to Zoran's understanding of the spatial complex, defined as the space "which the text actually presents" (1984: 322). For Chatman, story space - conceived as a spatial equivalent of story time - encompasses "what the reader is prompted to create in imagination [...], on the basis of the characters' perceptions and/or the 
narrator's reports" (1978: 104). Drawing on examples from visual narratives, Chatman distinguishes between explicit story space or "the segment of the world actually shown", and implied story space, typically established by means of the action (ibid.: 96). ${ }^{39}$

In addition to the previously listed spatial frames, "The Frog King" includes one location which is mentioned but never shown: the kingdom of the enchanted young king, where he presumably lived prior to his transformation and to which the newlyweds travel at the end of the story. The location is first mentioned by the king, who tells the princess the story of how he became a frog and then promises to "take her to his kingdom the next day" (Grimm 2003[1857]: 4). The second mention is linked to the appearance of the servant Heinrich, who drives a carriage up to the castle "to bring the young king back to his kingdom" (ibid.). However, fairy tales do not abound in this type of "unactualised" spaces; on the contrary, spaces that are mentioned are usually quickly visited by the protagonist. For instance, in "The Crystal Ball", the protagonist hears rumours about the enchanted princess who is at the castle of the golden sun, waiting to be rescued. One journey and one wish later, he finds himself at the castle, talking to the princess, who mentions a spring at the foot of the mountain, which, in turn, quickly becomes the setting for her rescuer's next adventure. Thus, the story space in fairy tales is often no more than the sum of individual spatial frames, as spaces where the story does not take place are rarely mentioned. In other words, if a space is mentioned, the reader may anticipate its appearance in the story.

\section{Storyworld}

When it comes to conveying information about a character, object, or environment, narration is inherently limited, meaning it can never address every single aspect of the thing it is presenting. For instance, if the focus is on a person, the text may list some of their distinctive features, such as age, height, or hair colour, but is unlikely to point out that they have shoulders, two eyes, or ten fingers. Thus, even description-

As a companion term to story space (and conceived in connection to discourse time), discourse space is defined as the "focus of spatial attention [...] the framed area to which the implied audience's attention is directed by the discourse, that portion of the total story-space that is 'remarked' or closed in upon" (Chatman 1978: 102, original emphasis). Ryan criticises the concept for failing to engage space in the same way discourse time engages time, proposing the spatial extension of the text as a more satisfactory alternative. As defined by Ryan, the spatial extension "refers to the spatiality of the text as material object and to the dimensionality of the interface with the reader, spectator or user" (2014[2009]: 799). It includes zero spatial dimension (music, oral narrative without gestures), quasi one-dimensionality (displayed text), two-dimensionality (film, printed text), and three-dimensionality (theatre) (ibid.). 
heavy narratives are ultimately riddled with information gaps or, as Roman Ingarden calls them, "spots of indeterminacy" (1973[1931]: 224). However, these gaps do not present an obstacle to understanding the story; on the contrary, the text uses various cues to prompt readers "to activate the appropriate contextual frames" and fill in the gaps by drawing from their own imagination, knowledge of the world, and experience with similar genres and literature in general (Nünning 2007: 99). The way the gaps are filled and the specific content used to fill them inevitably differ for each reader, whose interaction with texts is shaped by gender, culture, education, etc. (cf. Iser 1974[1972]).

When it comes to spatial information, readers draw from their knowledge of (among other things) spatial relations and real-world geography to fill in the gaps, and link all the locations (be they explicitly identified or implied) into "a coherent, unified, ontologically full and materially existing geographical entity" (Ryan 2014[2009]: 798). If the story is set in a city, readers will mentally divide that city into streets, neighbourhoods, buildings, etc., even if the text itself does not explicitly mention the individual spatial units. They are also aware that the city is part of larger spatial networks the narrative does not necessarily refer to, such as regions, countries, or continents. Even entirely imaginary worlds, commonly encountered in science fiction or fantasy literature, do not hinder readers' understanding: relying on what Ryan terms the principle of minimal departure, readers use their knowledge of the real world to construct the imaginary one (unless the text explicitly contradicts this; 1991a: 51). Finally, even if the text fails to identify a location, "readers will simply supply one. They will imagine the scene, and in order to do so, they have to situate it somewhere, however vague the imaginary place may be" (Bal 2017[1985]: 182-183, original emphasis).

As the reader gathers and pieces together narrative clues, the process of reading becomes an act of "ontological sleuthing" in which new information is continuously acquired and added to a "constantly modified and dynamic picture" (Gomel 2014: 31). This process of combining spatial information explicitly featured in the narrative (i.e. story space) with all the information provided by the readers produces a category which Ryan terms the storyworld or narrative world (2014[2009]: 798). Ryan's concept of storyworld is comparable to Zoran's total space, which includes both explicitly identified locations and those that are only implied (1984: 322, 329), as well as Dennerlein's narrated world (erzählten Welt), which encompasses "the plot as well as the totality of characters, objects and spatial conditions" (2009: 48). The cognitive narratologist David Herman defines storyworlds simply as worlds evoked by narratives, mental representations of "the situations and events being recounted of who did what to and with whom, when, where, why, and in what manner", which are based on blueprints provided by the narratives (2009: 106-107). 
Reading "The Frog King" (see Figure 1.), the audience is aware that there is more to this narrative world than just two castles and a forest, and are likely to imagine large (neighbouring?) kingdoms, which in themselves encompass a variety of spaces such as towns and villages, connected by roads. Furthermore, they understand the forest extends beyond the narrow space of the linden tree and well (the narrative suggests as much by describing the forest as large). The story supplies some clues that suggest the space does extend beyond what is explicitly mentioned. References to various characters in particular imply spatial extensions as each character presupposes a new and unique environment to which they belong. At the very beginning of the story, we learn that the king has several daughters (the number is never specified); later, courtiers are said to share the table with the king and the youngest princess; finally, the young king mentions an evil witch who turned him into a frog. Although the witch is not an active character in the story, her existence implies some kind of (magical) space in which she resides. Furthermore, references to various objects and activities further expand the spatial parameters of the narrative world. For instance, the coach which arrives at the castle to fetch the prince and princess must be driven by a coachman, and we might assume that the royal dining table is surrounded by servants. Faithful Henrich describes how he had three iron bands wrapped around his heart, an activity which presupposes both external assistance (probably a blacksmith) and a specific space (the blacksmith's shop). The specific strategies used to indirectly convey spatial information will be examined in more detail in Chapter 5.

The process of gap filling is aided by (among other things) readers' genre competence, familiarity with other versions or adaptations of the tale they are reading, and paratextual information (particularly illustrations). Genre schemata in particular, evoked by various textual elements such as opening formulae or stock characters, serve as "the frame for the reading process by informing the way readers form hypotheses and expectations" (Kukkonen 2013: 67-68; see also Kukkonen 2008). Drawing on their knowledge of the fairy-tale genre, triggered by the familiar opening formula, readers are likely to envision the storyworld of "The Frog King" as some version of quasi-historical (often medieval) ${ }^{40}$ Europe, complete with villages, wooden cottages, forests, and lofty castles, but not, for instance, urban metropoles, skyscrapers, or Moon colonies. Thus, even though the lack of concrete geography might suggest that the story can take place anywhere, there are some limitations to this as some locations will be dismissed as incompatible with the genre schemata (see Chapter 6).

40 For a discussion of the role of illustrations in lending fairy tales a medieval setting, see Hoogenboezem (2010). 


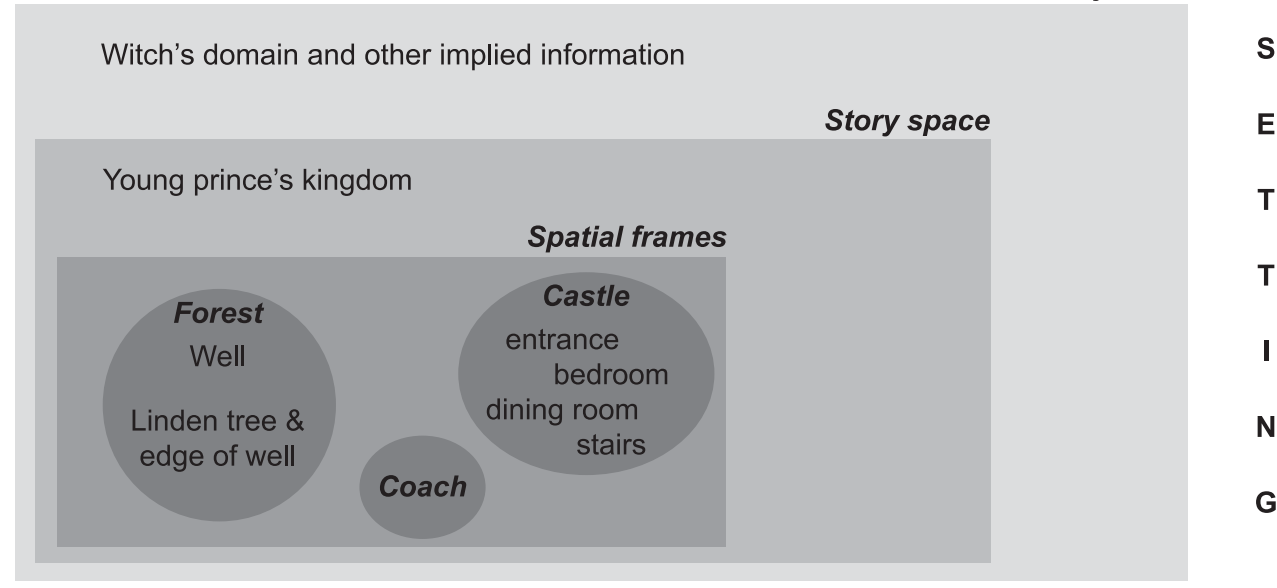

S

$E$

$\mathbf{T}$

$\mathbf{T}$

I

$\mathbf{N}$

G

Figure 1. The storyworld of "The Frog King" (Source: the author).

\section{Narrative universe}

The final category in Ryan's model is the narrative universe, which adds to the storyworld "all the counterfactual worlds construed by characters such as beliefs, wishes, fears, speculations, hypothetical thinking, dreams, fantasies, and imaginative creations" (2014[2009]: 798). Relying on the notion of possible worlds, ${ }^{41}$ which presupposes that reality encompasses a number of different worlds, both those that exist physically and those that are imaginable, the narrative universe is the sum of the "actual" or "real" world, meaning everything the characters understand to be "reality", and a number of alternative or non-actual possible worlds. The relationship between the actual and non-actual worlds has been variously interpreted. Ronen identifies three major approaches: modal realism, which suggests that all these worlds are parallel to and independent of each other, with the status of "actuality" attached to the world inhabited by the speaking/perceiving subject; moderate realism, which sees only the actual world as an autonomous unit, with possible worlds existing within its confines; finally, the anti-realist approach, which criticises the underlying assumption of an actual world, i.e. the idea that actuality can in fact be attributed to any single world (1994: 21-25). Ryan's definition, which presents alternative worlds primarily as products of mental activities (thinking, speculating, dreaming, imagining, etc.), subscribes to the second approach. Elsewhere, the author explores the relationship between the autonomous actual world (or factual domain) and the relative worlds whose existence is dependent on characters (Ryan 1985: 
720), and which are "nested" in the actual world (ibid.: 722). Depending on the type of mental activity that produces them, these worlds can be epistemic or knowledgeworlds (K-worlds, which have a hypothetical extension) and intention-worlds (Iworlds); model worlds, which include wish-worlds (W-worlds), worlds of moral values (M-worlds), and obligation-worlds (O-worlds); and finally alternate or counterfactual universes (ibid.: 722-732). Hilary Dannenberg also mentions emotions such as regret and satisfaction as means of constructing counterfactual worlds (2008: 120).

Following Ryan's model (cf. 1985: 731), the schema of the narrative universe of "The Frog King" is presented in Figure 2. The key elements of the factual domain of the story include the following facts, which are part of individual characters' $\mathrm{K}$ worlds to different degrees:

1. The frog is an enchanted prince (frog-K, Henrich-K);

2. The princess is the only one who can break the spell (frog-K);

3. The princess and the frog make a deal (frog-K, princess-K);

4. Henrich has iron bands wrapped around his heart (Heinrich-K).

The hypothetical extension of the characters' K-world comes into play during the bargaining scene in which both parties have a different idea of the stakes and outcomes. Assessing the situation, they consider different steps and their possible outcomes. In the case of the frog, they may be summarised as If I help the princess, she will become my companion, and even further: If I become the princess's companion, I will regain my human form. The reader is much more privy to the princess's thought process: If I promise to be the frog's companion, I will get my ball back, and, once that hypothesis has been confirmed, If I go back to the castle, the frog will not be able to follow me. This leads her to nominally agree to the frog's terms and run back home as soon as she gets what she wants (I-world). The frog's primary intention guiding his actions is to regain his human form. 


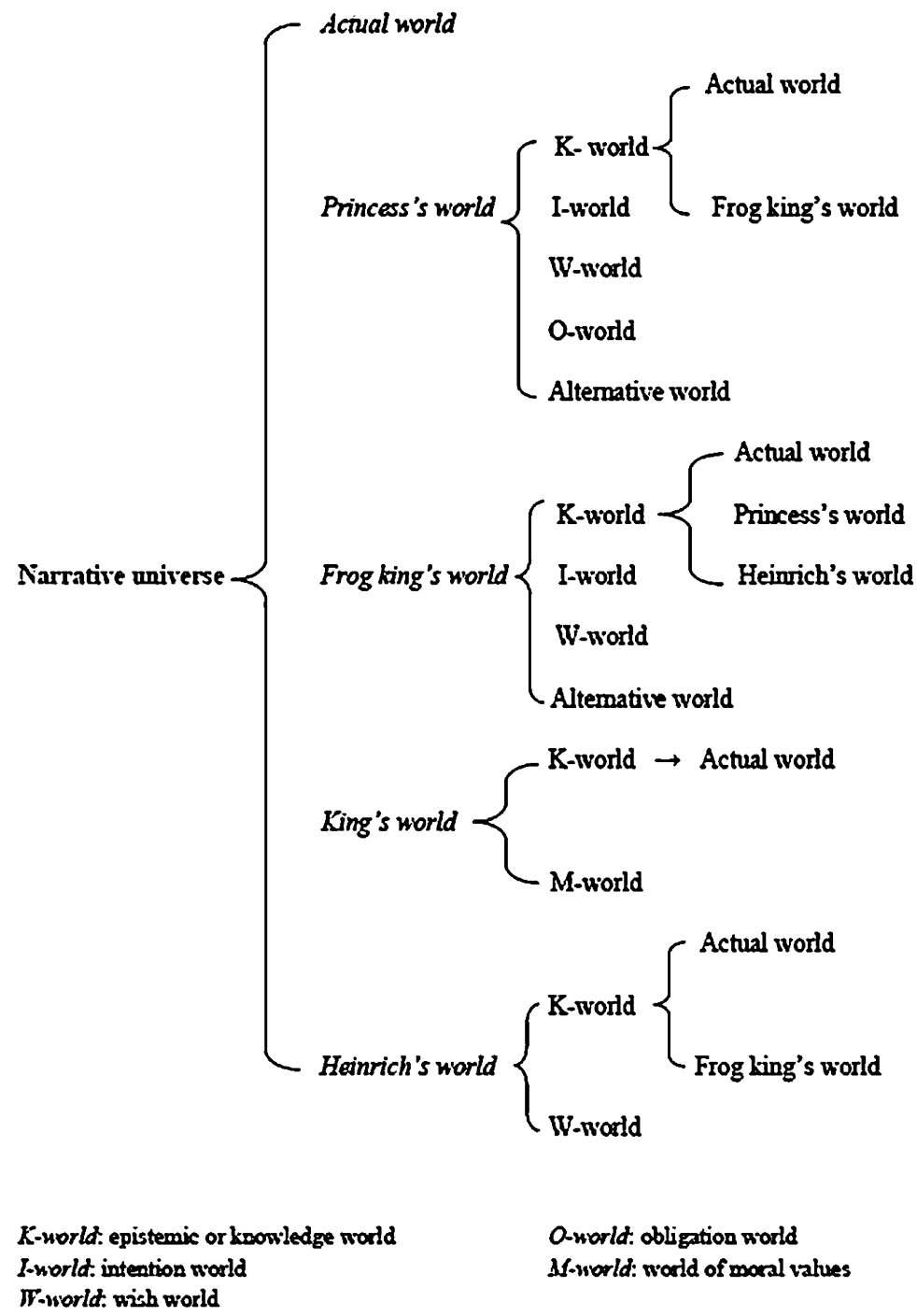

Figure 2. The narrative universe of "The Frog King" (Based on Ryan 1985: 731).

The $\mathrm{W}$-world of the princess is modified throughout the story as she is gradually faced with increasingly undesirable possibilities, until she is finally offered the most desirable outcome: marriage to a handsome prince. At the beginning of the story, she wants her golden ball. Having received it, she is forced into a series of unwanted situations: letting a frog into her home; picking a frog up and putting it on the table; sharing her food with a frog ("she did this, but it was quite clear that she did not like it"; Grimm 2003[1857]: 3); carrying a frog to her bedroom (she starts to cry). The final requirement - sharing her bed with a frog - is the most undesirable ("She did not even have enough courage to touch him, and yet, now she was supposed to let 
him sleep in her beautiful, clean bed"; ibid.: 3-4), prompting the princess to react. Other characters in the story have less varied and expansive W-worlds: the frog king's list of desirable outcomes includes becoming the princess's companion, sitting at her table, sharing her food, sharing her bed, becoming human, and becoming her husband; Heinrich only wants his beloved master to turn into a human.

Unlike W-worlds, which are built around the satisfaction of individual characters, "M-worlds specify what characters consider good or bad for all the members of a specific group" (Ryan 1985: 729). "The Frog King" presents the Mworld of only one character - the king, who insists on the importance of keeping one's promises and being kind to those who have shown you kindness. Imposed on his daughter, the king's M-world produces an O-world for the princess in which kindness and keeping promises are set up as supreme values. The $\mathrm{O}$-world is built around a contract of sorts, the breaking/honouring of which leads to punishment/rewards (ibid.). However, the actual outcome of the story challenges this contract since the princess is "rewarded" with a royal husband even though she is neither kind (she angrily flings the frog against the wall) nor true to her word (she does not let the frog sleep in her bed).

The existence of counterfactual worlds construed in wishes and dreams might at first glance seem incompatible with a genre in which wishes regularly come true. Similarly, dreams serve as a means of communication, rather than projections of imagined possibilities. In dreams, characters facing insurmountable problems may learn where to go and what to do ("Jorinda and Joringel", KHM 69, ATU 405; "The Nixie in the Pond", KHM 181, ATU 316, 313). In cases like this, dreams and wishes do not create counterfactual worlds since they serve as precursors of events in the actual world, rather than their alternative. However, if the wish fulfilment turns a possibility into a reality, then the possibility of its non-fulfilment can also be seen as the seed of a counterfactual world. In other words, the act of making a wish creates a narrative fork in the road with two hypothetical outcomes: either the wish will be fulfilled, with its realisation taking place in the actual world and its non-realisation creating a counterfactual world, or it will not be fulfilled, forming a counterfactual world within the narrative universe.

Furthermore, Lüthi's observations on fairy-tale characters as essentially "flat" figures deprived of psychological depth and sentiment (1986[1947]: 12-13) might lead us to exclude emotions and various mental activities as possible sources of counterfactual worlds. However, the Grimms' fairy tales suggest otherwise. In "The Frog King", counterfactual worlds mostly stem from characters' beliefs and thoughts. The princess promises to be the frog's friend because she is convinced the amphibian could never leave the pond ("I never thought he'd get out of the water"; Grimm 2003[1857]: 3); once she gets her ball back, she runs home without giving the frog another thought. In her mental model, her benefactor is constrained within the well, forced to sit "in the water 
croaking with the rest of the frogs" (ibid.: 2). In "The Three Snake Leaves" (KHM 16, ATU 612) and "Snow White" (KHM 53, ATU 709), the antagonists similarly construct a counterfactual world built around the false conviction that members of their family (husband, stepdaughter) are dead. Another counterfactual world in "The Frog King" is suggested by the witch's spell, which can only be lifted by the princess: in the actual world of the story, the princess meets the frog and breaks the curse; in the counterfactual world, the spell is not broken and the young king remains a frog.

Some of the characters in the Grimms' fairy tales, such as the young king in "Faithful Johannes" (KHM 6, ATU 516) or the heroine's father in "The Goose Girl at the Spring" construct counterfactual worlds by openly regretting their actions (doubting a loyal servant, banishing a daughter). Similarly, the heroine in "The Virgin Mary's Child" feels longing and regret when thinking about the happy times she experienced in heaven. Finally, counterfactual worlds in fairy tales may be evoked by the narrator, who draws attention to possible alternative outcomes of characters' actions, for instance: "He would certainly have been lost had he not been wearing his hat" (Grimm 2003[1857]: 192); "That would have been the end of the poor maiden had she not been standing in a corner and listening to everything" (ibid.: 196); "So he put his staff into the basket, and it was lucky he did this, for they let the basket drop when it was halfway up, and if Hans had really been sitting in it, he would have died" (ibid.: 498).

\section{Modifying Ryan's model}

Exploring fairy-tale space through the lens of Ryan's categories reveals it as complex and multi-layered, created through a number of direct and indirect strategies. Relying on reader participation, constructing space is a dynamic process in which space is constantly re-negotiated and re-created as readers learn new information and revise their mental model of space accordingly (cf. Kukkonen 2014). As both Dennerlein and Ryan have argued, narrative space is not a fixed, immutable narrative element; on the contrary, it is a constant work in progress as the existing model is continuously modified with the addition of each new piece of information. As such, it is a dynamic product of the ongoing interaction between different narrative facets, which include not only the information explicitly provided by the text, but also implied information, possible and probable worlds, as well as readers' mental models. Moreover, it exists in innumerable different versions as readers, drawing on their own knowledge and experience, will each create their own unique mental model of space. Chatman highlights this when comparing cinematic representations of space, which he describes as fixed, and their literary counterparts, which are abstract. Thus, despite being provided with the same information, each reader interprets them through a different lens (shaped by their own knowledge, cultural background, experience, etc.), thus constructing a different mental construct of space (Chatman 1978: 101). 
When applied to the fairy tale, the different categories in Ryan's model reveal a complexity of narrative space by highlighting that there are different types of space - from the immediate physical surroundings of characters and objects (spatial frames), to those that are mentally constructed by characters or readers (storyworld, narrative universe) - which are created through an interplay of different narrative strategies, types of information, and degrees of interaction between text and reader. Perhaps most importantly, they challenge the traditional view voiced by scholars such as Lüthi (1986[1947]) and Leeuwen (2007), according to which fairy-tale space does not exist independently of the action and characters. As the discussion of the different categories of space highlights, the spatial extension of a narrative goes beyond the explicitly identified locations which serve as settings for events. Rather than being the only manifestations of the text's spatial dimensions, they are merely the most prominent ones.

However, despite their usefulness for revealing the complexity of narrative space in fairy tales and providing a blueprint for its structural organisation, narratological models such as Ryan's are not genre-specific; rather, they provide insight into how narrative space in general works, regardless of the genre and other specifics of the narrative in question. Suitable for the study of any type of narrative (the author explains the individual categories using James Joyce's short story "Eveline" as an illustration), Ryan's model therefore does not reveal whether there is anything about spatial structure and narrative space in general that is specific to the fairy tale (and if so, what it is). To explore this issue, the present thesis proposes an additional step, which consists of modifying Ryan's narratological model to better reflect what is unique to the fairy tale and fairy-tale space. In this way, it not only contributes to fairy-tale scholarship by applying narratological research to it, but also, by conducting genre-oriented research within a narratological framework, to narratology. To modify - more specifically, expand - Ryan's model, this research turns to Lüthi (1986[1947]), who identifies spatial relations as an important factor for distinguishing between the fairy tale and legend. Specifically, Lüthi's discussion of the relationship between the human and "other" world outlines a different, more genre-specific type of spatial organisation than the one proposed by Ryan.

As indicated by Lüthi's two-world model of space, the fairy tale is "modally heterogeneous" (or dyadic; Doležel 1998: 128), divided into two distinct, antithetical modes of existence: one encompasses human characters and environments, which the audience may link to their own empirical reality, while the other features characters and occurrences that constitute a break from the said reality, such as dragons, giants, or wish-granting objects. Since the term "world" already appears in the name of one of the previously identified categories of space (narrative world or storyworld), the present research borrows a term frequently used in research on fantasy literature (the roots of which are often traced back to fairy tales; cf. 
Mendlesohn 2008): the realm or domain. Defined as "part of a world where the laws of nature and causality differ from the rest of the world" (Ekman 2013: 71), the domain is understood as an umbrella category which encompasses - or, in the case of narratives with multiple domains such as the fairy tale, cuts across - those categories in Ryan's model which refer to physical, material space. This means that it is primarily the storyworld that can be divided into different modes of existence (i.e. domains), while the category of narrative universe, with its various immaterial spaces, remains outside the boundaries of the domain. In the case of the fairy tale, individual (physical) spatial elements (whether explicitly or implicitly established) belong to either - to use Lüthi's terminology - the human or the "otherworldly" domain. In the previously used example of "The Frog King", the human domain encompasses the spatial frames of the castle and the forest, their implied surroundings, and the kingdom to which the newlyweds travel at the end of the story. While not explicitly depicted, the otherworldly domain encompasses the bottom of the well in which the frog lives, as well as the unidentified dwelling of the sorceress who turned the young king into a frog. With its bottom in the otherworldly and its edge in the human, the well functions as a passageway between the two domains.

The division of the fairy-tale world into two domains has already been recognised by numerous scholars: Propp, for instance, distinguishes between the real world and the magical, "unreal world, where all earthly laws are suspended" (1968[1928]: 166). In his essay "On Fairy-stories" (1965[1947]), J. R. R. Tolkien provides a productive basis for future classifications by introducing the terms primary and secondary world. Although Tolkien uses the terms to refer to the empirical world of the reader and the fictional world created by the literary text respectively, subsequent scholarship has transformed them into names for the realistic and non-realistic domain of the fantasy novel (see e.g. Zahorski \& Boyer 1982; Mendlesohn 2008). Jones notes that various quests lead fairy-tale protagonists from their own "quotidian world" (2002[1995]: 44) into "an essentially fantastic world" (ibid.: 16), a "magical or supernatural dimension" (ibid.: 45); Holbek describes this as the "move from the world of everyday life to the worlds of wonder" (1987: 17). Similarly, Tatar contrasts the genre's "realistically portrayed world" with the supernatural (2003[1987]: 57) or "magical foreign realm" (ibid.: 61). Messerli distinguishes between the magical world of supernatural beings and the non-magical world of human beings (2005: 274). Other scholars juxtapose the human world with "the supranormal" (Apo 1995: 228), the marvellous or Fairy Land (Jason 1988: 29), the "non-human" (Meletinskij et al. 1974[1971]: 102), and the "otherworld" (Bacchilega 1997: 8; Lüthi 1986[1947]: 6; Thompson 1977[1946]: 146).

In addition to the underlying agreement about the existence of two fairy-tale domains (usually termed worlds), the brief overview above also reveals the wide range of terms used to designate them. There appears to be little consensus on how 
these categories should be named, with individual studies often using terms such as magical, supernatural, and fantastic interchangeably. The following section will therefore discuss some of the terminological possibilities utilised in existing literature.

\section{A note on terminology}

To determine how to refer to the two fairy-tale domains, this section will consider the following terminological possibilities featured in existing literature: human/nonhuman, natural/supernatural, this world/Otherworld, realistic/fantastic, realistic/marvellous, and non-magical/magical.

Taking into consideration the identity of fairy-tale characters, the domains they inhabit may tentatively be termed human and non-human. The term "human" seems quite fitting as an entire domain of the fairy-tale world is, in fact, populated exclusively by human characters of various social standings and occupations. However, the opposite term is problematic since the inhabitants of the "non-human" domain include not only various non-human characters such as talking animals, ogres, and dragons, but also human characters skilled in the magical arts, such as witches or sorcerers. Additional problems stem from the fact that various monstrous creatures and talking animals are often revealed to be enchanted humans (humans "in disguise").

Largely reliant on belief, the term supernatural refers to things that lie beyond the boundaries of human understanding and experience, and are therefore recognised as inexplicable, mysterious, impossible, or at the very least - unusual (Valk \& Sävborg 2018a: 17). As such, it is better suited to genres such as legends or religious tales, in which the appearance of saints, ghosts, or demonic figures is clearly identified as "something wholly different from anything in ordinary life" (Lüthi 1986[1947]: 4), than fairy tales, in which encountering witches and dwarfs is part of everyday experience, and therefore perceived as "natural" rather than "supernatural". The term "superempirical" (Jindra 2003: 165) which has, due to certain controversial implications of the term supernatural, ${ }^{42}$ been proposed as its more acceptable alternative, further reinforces its unsuitability for the discourse on fairy tales. Thus, the "supernatural" in fairy tales is part of the empirical knowledge of the human

The term supernatural (especially when used as an etic term) has been a source of much contention among scholars - most notably anthropologists - owing to its Western/Christian-centric nature, reliance on a dichotomy (nature/spirit) that does not exist in all cultures, and overall cultural baggage. For these (and other) reasons, some scholars (most notably Klass 1995; see also Jindra 2003) have called for its rejection. For a more extensive discussion on this topic, see the special issue of Anthropological Forum (13/2) edited by Roger Lohmann (2003). 
characters, who frequently interact with magical characters or use magical objects. In a world in which helpful giants and common woodcutters are depicted as equally "factual" (Reisz 2017[1979]: 159), the supernatural simply does not exist.

Another term frequently used in discussions of non-empirical fictional worlds is the o/Otherworld, which is juxtaposed with "this" or "our" world (meaning the empirical human world). In its widest, most general use, the term refers to any fictional place that does not conform to the rules of extra-literary reality (cf. Carey 1987). However, in its narrow sense it designates a very specific type of nonempirical space, inhabited by fairies (Greenwood 2000: 46, n.2), spirits (Boyd 1996), ancestors, gods, and other immortal beings (cf. Coulter 1925; Power 1985). Furthermore, the Otherworld often exists on a plane that is separate from earthly existence (Arthur Wachsler, for instance, contrasts the Otherworld and the terrestrial world; 1975) and can only be "experienced in an alternative state of consciousness", such as a trance triggered during special (e.g. shamanic) rituals (Greenwood 2000: 1). It often operates under a special set of rules, particularly when it comes to time, which either flows much faster or much slower there than in the human world (Carey 1987: 8, 14). It may be well concealed or separated from the human world by large expanses of land or water (ibid.: 2, 7). As with supernatural, the problem with this term is that the non-empirical in fairy tales is not perceived as "other", but as "part and parcel of everyday reality" (Tatar 2003[1987]: 61). Thus, when the desperate miller in the Grimms' "Rumpelstiltskin" (KHM 55, ATU 500) claims that his daughter can spin straw into gold, not only does no one question this notion, but the unfortunate girl is expected to demonstrate this skill.

Moreover, calling the human domain of the fairy tale "this world" or "our world" seems equally unsuitable. Thus, while being devoid of what the audience perceives as "obviously impossible" (Suvin 2010[1979]: 41-42), such as magical characters and occurrences, the human domain is nevertheless characterised by a worldview which readily accepts the existence of those same "impossible" characters and occurrences as something unremarkable. The same argument can be used against the application of the term realistic (presuming, of course, that literature can accurately represent extra-literary reality, ${ }^{43}$ a notion which has been widely challenged, ${ }^{44}$

43 For an extensive and influential discussion on the mimetic properties of literature, i.e. its ability to (more or less) accurately represent extra-literary reality, see Auerbach (2003[1946]).

44 As Robert Scholes writes in his analysis of the so-called realism fallacy, "[a]ll writing, all composition, is construction. We do not imitate the world, we construct versions of it" (1975: 7). Recognising the drawbacks of the notion of literature as a mirror of reality, many scholars opt instead for a modified, "softened" definition of a realistic text as one which merely "pretends that the fictional universe is a copy of the empirical one" (Zgorzelski 1984: 302, original emphases). 
primarily on the basis of essential ontological differences between literature and extra-literary reality; Doležel 1998: 1-28).

The fact that the fairy tale presents a departure from (or even a rejection of) conventional realism opens the possibility of applying to it a term often viewed as the polar opposite of the realistic: ${ }^{45}$ the fantastic. ${ }^{46}$ In the widest - and somewhat (over)simplified - sense, the fantastic in literature is defined as, to use Jonathan Perkins's vivid image, a "broad portmanteau for all non-realistic elements" (2008: 363). In other words, any element that does not comply with readers' experience of reality may be labelled fantastic (Jackson 1991[1981]: 13-14). ${ }^{47}$ While this wide meaning of the term as a synonym for non-realism may be applicable to the fairy tale, the same cannot be said for its more specific meanings, typically associated with the eighteenth-century Gothic novel and nineteenth-century German Romantic writers (cf. Whitehead 2008). In this narrow sense, the fantastic is defined in terms of uncertainty and hesitation experienced by protagonists - and, by extension, readers - who find themselves in situations in which familiar rules of reality are suddenly broken by an unexplained occurrence (Todorov 1975[1970]: 25):

The person who experiences the event must opt for one of two possible solutions: either he is the victim of an illusion of the senses, of a product of the imagination - and laws of the world then remain what they are; or else the event has indeed taken place, it is an integral part of reality - but then this reality is controlled by laws unknown to us. Either the devil is an illusion, an imaginary being; or else he really exists, precisely like other living beings [...]. The fantastic occupies the duration of this uncertainty.

As a genre in which impossible occurrences do not constitute a departure from the reality of the text, the fairy tale does not recognise this type of hesitation on the part of the characters (or the implied reader). Characterised by ambiguity, uncertainty, and indeterminacy (Nikolajeva 2003: 154), the fantastic presents an anomaly in the narrative world, an intrusion, a breach of the internal laws established by the text

45 The dualistic approach that sees the realistic and the fantastic as two clearly delineated opposites has not gone unchallenged. Scholars such as Kathryn Hume (1984) and Matthew Grenby (2008) have argued that the relationship between the two concepts, which are often blended together, is much more nuanced. as well as Hume (1984) and Peruško (2018), who offer extensive overviews of literature.

47 Additional problems stem from the inconsistent use of the terms fantastic and fantasy, which are often indiscriminately used to denote a genre, style, narrative technique, mode, or type of popular fiction (Nikolajeva 2003: 138). 
(Zgorzelski 1984: 302, n.8), which stands in stark contrast to the unexamined acceptance of impossible occurrences that characterises the fairy tale.

In Tzvetan Todorov's influential discussion $(1975[1970]),{ }^{48}$ the fairy tale stands outside the boundaries of the purely fantastic, which exists in the state of uncertainty. This state can only be sustained for a limited amount of time and must eventually be resolved, either by discovering a rational explanation for the extraordinary events (Todorov terms this the uncanny; 1975[1970]: 41) or by accepting that that they are, in fact, supernatural. Todorov terms the "supernatural accepted", in which nonrealistic elements are an integral and accepted component of the narrative world, the marvellous (ibid.: 42). Differentiating between several types of the marvellous (hyperbolic, exotic, instrumental, and scientific, as well as "hybrid" forms such as the fantastic marvellous; ibid.: 54-57, 44), Todorov finds its purest expression in the fairy tale. Although he ascribes to the marvellous the same one-dimensionality which Lüthi identifies as one of the hallmarks of the genre, the problem with Todorov's term lies in the specific connotations it has within the French fairy-tale tradition. As Lewis Seifert contends in his study of late-seventeenth- and early-eighteenth-century French fairy tales, the marvellous (merveilleux) is "by no means a feature of all folkand fairy tales. It does, however, recur with great frequency in literary fairy tales and [...] is an intrinsic feature of the seventeenth-century contes de fées" (1996: 21-22). Playing a key role in the French fairy tale's "larger project of nostalgic recuperation and recreation of (what is perceived to be) a lost social cohesion and interaction", the marvellous creates a space for writers to simultaneously reproduce existing social structures, and challenge them by revealing their problems and proposing alternatives (ibid.: 22). Defined in this way, the merveilleux is linked to the literary fairy-tale tradition, which often deliberately and consciously uses fantasy to challenge the dominant social and political order, (traditional) gender roles, etc.

In his exploration of the European fairy tale, Messerli notes that it consists of "two non-homeomorphic worlds - a magical world of supernatural beings from the beyond, and a non-magical one of normal human beings" (2005: 274, emphases added). Unlike the previously discussed terms which take the world "of normal human beings" as their starting point and define the "other" domain as its opposite, Messerli's non-magical/magical juxtaposition foregrounds the "other", nonempricial world. The juxtaposition is based simply on the absence/presence of magic, rather than its evaluation as factual or non-factual, a transgression or reflection of the natural laws of the narrative universe. Furthermore, the term magical successfully encapsulates the specific type of the non-empirical found in fairy tales, one that completely dismisses the rules of empirical reality without providing 
explanation for its "impossible" features. The inextricable link between fairy tales and magic is also evident in the term tales of magic or magic tales (Zaubermärchen), often used to refer to the genre. Tatar notes that the term magic (or wonder) tale featured, perhaps most notably in the Aarne-Thompson-Uther Index of international tale types (ATU 300-749) - is preferred by folklorists, with the fairy tale being its more popular and widely used alternative (2003[1987]: 61). ${ }^{49}$ Even scholars who prefer the term fairy tales acknowledge the central importance of magic for the genre (cf. Jones 2002[1995]; Warner 2014); Thompson, for instance, identifies it as "almost universal in some form in all those stories we know as wonder tales" (1977[1946]: 67). For all these reasons, the present research terms the two domains of the fairy tale the non-magical and the magical.

\section{Domain and genre}

Having introduced the category of the domain into Ryan's model, the present chapter explores in more detail its contribution to the discussion on fairy-tale space. Specifically, this section focuses on the genre-specific aspects of the new category of space and asks how it allows for a more genre-centred perspective in explorations of spatial issues.

As previously mentioned, the need to modify Ryan's model stems from its applicability to different narratives regardless of their genre traits. The addition of the domain creates a platform for explorations of space that consider the specificities of individual genres (in this case, the fairy tale). In other words, it provides a heretofore overlooked perspective on genre which considers narrative space as a possible criterion for genre classification. Already the number of domains can, to some extent, serve as the basis for distinguishing between different genres: thus, the dyadic (double-domain) fairy tale can be distinguished from genres with only one

49 While many scholars see the terms fairy tale and magic tale almost as synonyms, often using them interchangeably (e.g. Järv 2005), some associate the magic or wonder tale exclusively with the oral tradition (e.g. Zipes 2002[2000]a). In view of the unique nature of the magic they represent, Bottigheimer (2014) considers fairy tales to be a sub-type of the older magic tale. Specifically, she juxtaposes pre-Renaissance magic tales in which "magic often operates from a parallel world and affirms existing earthly and supernatural hierarchies" (Bottigheimer 2014: 1), with rags-to-riches fairy tales which, according to her, first appeared in Giovan Francesco Straparola's sixteenthcentury collection Le Piacevoli Notti (2002; many scholars have challenged these claims, see, for instance, Bacchilega 2007b; Ben-Amos 2010; Ziolkowski 2010; Zipes 2012: 157-173). In fairy tales, magic unfolds in the world of the protagonists and is largely human-centric (Bottigheimer 2014: 8). 
domain, such as the folk tale ${ }^{50}$ (which consists of a single, "realistic" domain) or the animal tale (encompassing one, "non-realistic" domain). Moreover, the existence of one or more domains can shed some additional light on contested genre categories, such as the humorous tale (Schwank). To demonstrate the usefulness of the category of domain in genre classification, this section discusses single-domain KHM genres - specifically, the animal tale, folk tale, humorous tale, and formula tale - and contrasts them with the dyadic fairy tale.

The animal tale is defined as a (usually short) prose narrative featuring anthropomorphised animal characters (Bies 2009: 624; see also Rudd 2009). Although anthropomorphised animals enjoy considerable popularity and are found in virtually all genres, only in the animal tale do they become the focus of narrative interest, often assuming all - or at least the most prominent - roles (Sydow 1948[1938]: 133-134). While their name might suggest otherwise, these tales do not feature only animals, but may also add anthropomorphic objects, plants, and even humans to their cast of characters ${ }^{51}$ (the latter usually assuming only minor, secondary roles; e.g. the farmer and his wife in "Old Sultan", KHM 48, ATU 101, 103).

However, character identity is not the most reliable criterion for genre classification, not only because animal characters appear across genres, but because different variants of the same tale type may cast different characters in the same roles (for example, a gullible bear found in one variant of a given tale can be substituted with a stupid ogre in a different one). These and similar issues have led some scholars to conclude that animal tales are not a separate genre, but rather a kind of umbrella term for generically diverse narratives which vary in length, function (e.g. didactic animal tales, aetiological legends featuring animals), content, tone (e.g. humorous animal tales), style and form (animal chain tales), with animal characters as their only common denominator (cf. Bies 2010). Others, among them Propp, maintain that despite all their differences, animal tales do in fact share certain features beyond the identity of characters, which justifies their status as a separate genre (1968[1928]: 284). A space-centred exploration of the KHM animal tales supports the view that these narratives constitute an independent genre category, one that is characterised (among other things) by a single, non-realistic domain which encompasses a variety of human/man-made and animal (natural) spaces.

50 To avoid confusion, the present discussion follows Tatar's example and distinguishes between folktales as a group of prose narratives (Märchen) and folk tales as a distinct genre within that category (2003[1987]: 33).

51 To distinguish between animal tales that feature only animals and those with a more diverse cast of characters, some scholars use the term "beast" or "animal fable" (Dithmar 1984: 736; Grenby 2008: 10) to refer to the former. 
The single domain of the animal tale can be described as "non-realistic", nonhuman or animal. The term magical does not apply to this domain since the "nonrealism" of animal tales is decidedly different from the "non-realism" of fairy tales and is not predicated on magic. The genre shares the fairy tale's ontological homogeneity as human characters do not appear unnerved by the animals' ability to speak and are able to communicate with them (e.g. "The Marvelous Minstrel", KHM 8, ATU 38, 151; "The Dog and the Sparrow", KHM 58, ATU 248, 223). Unlike the fairy tale, the storyworld of the animal tale consists of a single, hybrid domain in which the human and the non-human are not separated by firm boundaries but overlap. Sometimes this hybridity is seen in the fact that animals inhabit human spaces: in "The Companionship of the Cat and the Mouse" (KHM 2, ATU 15) or "The Mouse, the Bird, and the Sausage", the titular characters live in human houses, where they engage in human activities, such as cooking or keeping house. Animal tales that feature human characters such as "Riffraff" (KHM 10, ATU 210), "Old Sultan", or "The Wolf and the Fox" (KHM 73, ATU 41, 122) often juxtapose animal (the hill, the forest) and human spaces (the farm, the inn). However, the boundary separating the human and the natural does not separate different modes of existence; rather, both human and animal spaces are accessible to and populated by anthropomorphic animals.

The hybridity of the animal tale's single domain is likely to stem from the "hybrid" nature of the animal characters themselves. Although traditionally interpreted as "humans wearing animal masks" (Briggs 2002[1970]: 15), animal characters display both human and animal traits. In addition to their ability to speak, they share many other similarities with humans, from forming familial relationships (husbands and wives in "The Hare and the Hedgehog", KHM 187, ATU 275C) and waging war against each other ("The Wren and the Bear", KHM 102, ATU 222), to riding around in carriages ("Riffraff"; "Herr Korbes", KHM 41, ATU 210), wearing clothes ("The Wedding of Mrs. Fox", KHM 38, ATU 65), and christening their children ("The Fox and His Cousin", KHM 74, ATU 3*). Despite their anthropomorphisation, they retain their animal nature and habits to some degree: for instance, the cat who sets up a household with the mouse licks fat from the jar, strolls across rooftops, and wipes his whiskers ("The Companionship of the Cat and the Mouse"). Being both human and animal (cf. Hameršak 2015), these characters inhabit "a tantalizingly ambiguous middle-world between human society and animal nature" (Marcus 1983/84: 128). This ambiguity is translated onto the spatial plane as a hybrid domain created at the intersection of the human and the animal.

In contrast to the "non-realistic" animal tale, the Schwank or humorous tale is usually described as a more "realistic" genre. The term covers a wide spectrum of KHM narratives - from brief, mono-episodic humorous anecdotes such as "The Maiden From Brakel" (KHM 139, ATU 1476A) to lengthy, multi-episodic tales such 
as "Freddy and Katy" - which generate humour by exposing something or someone to ridicule. A frequent target of mockery is human flaws and vices, especially stupidity ("The Seven Swabians", KHM 119, ATU 1321C, ATU 1231, 1297*), laziness ("Lazy Heinz", KHM 164, ATU 1430, 1430A), greed ("The Good Bargain”, KHM 7, ATU 1642, 1610, 1642A), gluttony, lust, and (religious) hypocrisy ("Old Hildebrand", KHM 95, ATU 1360C; Davies 1998: 28). ${ }^{52}$ Since these traits are often highly exaggerated for comic effect, the realism of the Schwank tale is at times brought into question.

Tales depicting the "outrageously" stupid exploits of numskulls (Krikmann 2008: 4), who take everything literally ("Clever Hans", KHM 32, ATU 1685, 1696; "Going Traveling", KHM 143, ATU 1696), or send a cheese to fetch another wheel of cheese that had rolled down the hill ("Freddy and Katy"), often verge on the impossible. According to Jason, the extreme stupidity of numskulls which exceeds the boundaries of "normality" is translated onto the spatial plane; thus, what she considers the dyadic storyworld of the numskull tale consists of the world of "normal" people and the numskull world (1972: 13). The two are usually separated by an in-between space or barrier that can be physical and/or symbolic (difference in ethnic or social status, or even mental state; ibid.: 16-17). The present research offers a different perspective on this issue by arguing that despite their frequent physical separation from the rest of the world (e.g. the island communities in "The Three Sons of Fortune", KHM 70, ATU 1650, 1202, 1281, 1651), numskull communities do not constitute a different, non-realistic domain, since their exaggerated traits and outrageous behaviour are often the result of faulty logic or unexpected adaptations to unusual living conditions (e.g. in "The Three Sons of Fortune", the island community that is unfamiliar with the scythe uses canons to cut down grain), rather than supernatural attributes. Furthermore, as Christie Davies points out, Schwank narratives are not really meant to be realistic to begin with: rather, they openly rely on caricature, hyperbolisation, and similar strategies to create an exaggerated, more or less distorted version of reality, rather than reality itself (1998: 53). In other words, they rely on a special type of "realism" which allows for a certain degree of exaggeration and distortion of extra-literary reality. However, this distortion never takes on the form of an outright departure from reality or the breaking of natural laws that would point to the existence of an additional, "nonrealistic" domain.

52 Sometimes these (exaggerated) negative traits are ascribed to members of ethnic, religious, and other minorities, certain social groups and occupations, and inhabitants of specific geographical areas, such as villages, towns, regions, or entire countries (Davies 1998; Jason 1972: 7, 8). 
Some scholars claim that, in addition to its propensity for exaggeration, the Schwank can, in fact, contain non-realistic elements. Lutz Röhrich, for instance, proposes a classification of the Schwank depending on the absence ("pure" Schwank) or presence of non-realistic elements ("hybrid" Schwank; 1991[1956]: 52). The KHM corpus confirms this possibility, as many of its Schwank narratives do, in fact, feature non-realistic occurrences, environments, and characters, the existence of which suggests that the genre is actually a dyadic, rather than a single-domain one. The miracles performed by St Peter in "Brother Lustig" (KHM 81, ATU 785, 330), the appearance of supernatural characters such as devils ("The Peasant and the Devil", KHM 189, ATU 1030) and giants ("The Giant and the Tailor", KHM 183, ATU 1049, 1053, 1051), or the ascent to heaven in "The Fleshing Flail From Heaven" (KHM 112, ATU 1960A, 1960G, 1174, 1889, 1882), reveal a different organisation of the storyworld, one which encompasses both a "realistic" human domain and a "non-realistic" domain of supernatural characters. While all Schwank tales featured in the KHM share some thematic similarities (e.g. triumph of the underdog, mocking exaggerated flaws) as well as the central aim of generating humour, stark differences in the spatial organisation of individual narratives challenge the notion that they constitute a separate generic category.

The status of the Schwank as a separate genre category has already been brought into question. The fact that "the comic can take hold of any narrative genre" (Röhrich 1991[1956]: 52) has led many scholars to conclude that humour is an unreliable criterion for genre classification. Lüthi, for instance, argues that any genre has comic potential, which can manifest itself as a distinct sub-category, such as the jocular anecdote or the farcical fairy tale (1974: 15). The different spatial structures of the "realistic" ("pure") and the "non-realistic" ("hybrid") Schwank support the notion that the comic is a literary mode (manner of expression), which exists independently of genre and can become attached to a particular genre, rather than a genre in its own right (cf. Roston 2011). Considered from a spatial point of view, the "realistic" Schwank can therefore be seen as a sub-genre of the folk tale, the nominal realism of which has more to do with the absence of magical objects, creatures, and events, than the outright imitation of extra-literary reality, and as such also permits a certain degree of exaggeration and implausibility (Tatar 2003[1987]: 122) ${ }^{53}$ In contrast, the "non-realistic" Schwank which portrays humorous interactions between human and supernatural/magical characters can be seen as a sub-genre of the various dyadic

53 Consider, for instance, the Grimms' "The Clever Farmer's Daughter" (KHM 94, ATU 875): though devoid of overtly supernatural or magical elements, the tale nevertheless contains several instances which may require some suspension of disbelief on the part of the reader, most notably the episode in which the naked heroine wraps herself in a fishing net and is then dragged all the way to the king's palace. 
genres, such as the fairy tale ("The Giant and the Tailor") or the religious tale ("The Fleshing Flail From Heaven").

What distinguishes formula tales from other genres is their emphasis on form, understood as principles that determine how a particular text is organised and ordered (Abrams 1999[1957]: 101). More specifically, the way in which individual plot elements (e.g. episodes) are organised is given precedence over their content, which is why these narratives often feature only a semblance of story or even dispense with it altogether. The Grimms' "The Domestic Servants" (KHM 140, ATU 1940), for instance, consists of nothing but dialogue built around the repetition and accumulation of nonsensical names (Hippodeige, Cham, Do-It-Right). The focus is, therefore, less on the story and more on the gradual accumulation of characters, episodes, etc., which typically serves as the basis for numerous repetitions with variations and/or additions (Wienker-Piepho 1993: 1195). The KHM features several sub-types of the formula tale: the cumulative tale, based on the accumulation of the largest possible amount of a given narrative element; the chain tale, which is created through continuous additions of new narrative elements ("links" in the narrative "chain") as well as the repetition of existing ones (Thompson 1977[1946]: 234); the catch tale, such as "The Golden Key" (KHM 200, ATU 2260) which plays with and eventually disappoints audience expectations by, for instance, omitting the ending (Dégh 1976: 72); and the endless tale, which relies on a potentially indefinite number of repetitions of a single episode (Thompson 1977[1946]: 229). The division between the different types is not always clear as individual tales can contain elements of more than one type of formula tale. "The Death of the Hen" (KHM 80, ATU 2021), for instance, begins as a chain tale in which each new character the rooster asks for help presents a new "link" in the chain; following the titular event, the second part of the story resembles a cumulative tale built around a continuously expanding funeral party for the hen (Kujundžić 2012a: 186-190).

Depending on the nature of the main characters and the events depicted, the single domain of the formula tale can be either non-realistic or realistic. "The Louse and the Flea" (KHM 30, ATU 2022), "The Death of the Hen", "The Fox and the Geese" (KHM 86, ATU 227), and "Tales About Toads (iii)" (KHM 105) all enfold within a domain populated by anthropomorphic animals, objects, and plants, as well as the occasional human character ("The Louse and the Flea", "Tales About Toads (iii)"); in contrast, the single domain in "Pretty Katrinelya and Pif Paf Poltree" (KHM 131, ATU 2019), "The Domestic Servants", "The Nail" (KHM 184, ATU 2039), and "The Golden Key" appears completely human and realistic. Although it might seem that the lack of a qualitatively unique domain challenges the status of the formula tale as an independent genre, this is not the case for two reasons: first, unlike the case of the Schwank, the existence of a single domain is a constant in all the tales identified in our research corpus as formula tales, even if their (non- 
)realistic nature is not. Second, because the genre is not overly concerned with telling a story, meaning that all elements of that story - space included - are secondary to its formal features and narrative strategies, the quality of the domain appears less significant. As a result, the fact that some tales feature a realistic domain and others a non-realistic one does not invalidate the status of the formula tale as an independent, single-domain genre.

\section{The dyadic world of the fairy tale}

The existence of two antithetical domains distinguishes the fairy tale from the various single-domain genres discussed above. However, their presence alone is not unique to the fairy tale; on the contrary, genres such as legends or religious tales also encompass one human, "realistic" domain and one that might tentatively be labelled as non-realistic or supernatural. Taking its cue from Lüthi (1986[1947]), the present research argues that what does set the fairy tale apart from other dyadic genres is the spatial construction and relationship between its two domains.

Lüthi (1986[1947]) stresses the importance of the relationship between the fairytale domains as a genre-specific feature in his comparison of the fairy tale and the legend (see also Lüthi 1976[1969]a). Specifically, he describes this relationship in terms of distance, insisting that the physical division between the magical and the non-magical is manifested as immense spatial distances. These, Lüthi claims, compensate for the absence of an ontological "distance" between the non-magical and the magical (1986[1947]: 9, 43). In other words, because the "otherworld" is not really perceived as "other", it must be located far, far away (the opposite is true of legends). Messerli also notes that the magical domain is "remote" from the nonmagical one, forcing protagonists to "undertake long wanderings" to reach it (2005: 277).

While building on Lüthi's insistence on the importance of spatial organisation, the present research challenges his claims regarding spatial separation between the domains by proposing that, while a prevalent motif, large distance is not the only means of separating the non-magical from the magical. In fact, it is mostly reserved for quest or adventure fairy tales in which protagonists have to travel far and wide to encounter the magical. However, this is not the case in all (KHM) fairy tales; on the contrary, as tales such as "Cinderella", in which the heroine receives magical assistance at the near-by grave of her mother, or "Rapunzel" (KHM 12, ATU 310), in which the sorceress lives next door to Rapunzel's parents, show, the magical may be lurking just around the proverbial corner. Furthermore, not all fairy tales depict the journey into the magical domain or even (explicitly) the magical domain itself. In "Rumpelstiltskin" or "Brier Rose" (KHM 50, ATU 410), not only do protagonists not journey into the magical, but the magical appears within the non-magical 
domain, suggesting that the transference between the realms unfolds in both directions.

Since the fairy-tale domains are not necessarily distant from each other, this research argues that their relationship and spatial organisation are primarily characterised by clear spatial demarcation. In other words, the domains are separated by firm boundaries which can only be crossed temporarily and, as the following chapter will demonstrate, under specific conditions. In fact, it is precisely because the two domains may exist in close proximity to each other that they must be delineated and firmly separated by boundaries. In addition to large distances, the interdomain boundary can be manifested as a physical obstacle, such as the sea ("Faithful Ferdinand and Unfaithful Ferdinand", KHM 126, ATU 531), seashore ("The Fisherman and His Wife", KHM 19, ATU 555), river ("The Devil With the Three Golden Hairs", KHM 29, ATU 461, 930), or forest edge ("Hansel and Gretel", KHM 15, ATU 327A), or as a passage. A prominent place among the passages or "en route" spaces (Jason 1988: 74) in the KHM belongs to roads and wells. In "Mother Holle", for instance, a well connects the non-magical domain of the heroine (mouth of the well) and the magical domain of the titular helper (bottom of the well). Roads do not necessarily have to lead from the magical to the non-magical but can also serve as a liminal space in which the magical and the non-magical come into contact. More than one KHM protagonist meets a magical helper while on the road: in "The Griffin" (KHM 165, ATU 610, 513B, 461), for instance, the simple-minded Hans comes across a helpful dwarf while making his way to the palace. It should be noted that not all Grimms' fairy tales explicitly depict the interdomain boundary, just as they do not always explicitly depict the magical domain. The boundary can also be symbolic, manifested as the special conditions which have to be met in order for the non-magical and the magical to interact (see Chapter 4).

Although the two domains exist independently and separately from each other, one being generally inaccessible to inhabitants of the other, the fairy-tale narrative requires them to come into contact. This means that the characters who are initially separated and confined to their "native" or endemic domains must temporarily destabilise that separation and interact with each other, only to restore the initial spatial relations by returning to their endemic domain. The basic plot structure of the fairy tale can therefore be described, using Carl Lindhal's colourful image, as "a kind of magic sandwich" (2018: 13) in which the interaction between the non-magical $(\mathrm{N})$ and the magical (M) is bookended by (or "sandwiched" between) the initial and final separation (see Figure 3.). 


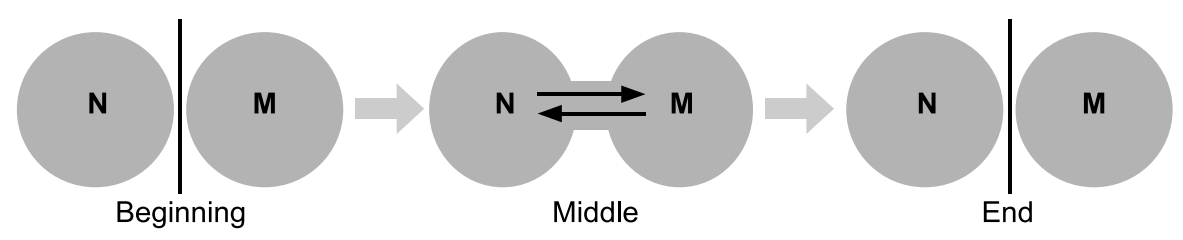

$\mathrm{N}$ : non-magical $\quad \mathrm{M}$ : magical

Figure 3. Fairy-tale domains (Source: the author).

The initial contact between the non-magical and the magical is typically established within some kind of liminal space such as the aforementioned road, heath, wilderness, or forest. Significantly, these are usually natural spaces, which stand in contrast to human (especially domestic) environments. In order to encounter the magical, the protagonist must therefore leave home. Unlike the two domains, the liminal space is accessible to both magical and non-magical characters. Jason lists the liminal or "in-between" space among the three worlds (domains) of the fairy tale (1988: 20). The present research does not consider the liminal to be a separate domain because it presents a kind of neutral ground between the non-magical and the magical, which belongs to both domains (cf. Lotman 1990: 136) while being neither magical nor non-magical itself. Moreover, no characters are "native" to the liminal space.

The encounter between the magical and the non-magical, a key "ingredient" of the fairy-tale genre, is therefore predicated on the crossing of spatial boundaries, i.e. spatial transference. The significance of spatial transference for the fairy tale has been extensively commented on in existing scholarship. For the most part, it is viewed as a fundamental structural principle (Propp 1990[1946]: 77), a narrative framework that allows for almost limitless insertions of new episodes (cf. Lüthi 1986[1947]). As a symbolically highly potent element, it has inspired a wide range of interpretations: some scholars understand it as a symbol of a rite of passage or initiation ritual (cf. Propp 1990[1946]), or some form of psychological development, especially the process of self-discovery, maturation (Bettelheim 1991[1976]), and socialisation (Zipes 2006[1983]). The journey into the unknown, magical domain is variously interpreted as a symbolic journey into the subconscious (Bettelheim 1991[1976]) or even the afterworld, the realm of the dead (Röhrich 2008[2002]: 96). Furthermore, some definitions of the genre, such as the one proposed by Propp, highlight the dynamic nature of the fairy-tale narrative, describing it as a series of transferences of the wandering hero/ine (1990[1946]: 34-35). The fairy-tale protagonist is often defined precisely in terms of his or her mobility, as a "freemoving wanderer" (Lüthi 1970[1962]: 141) who "goes off into the unknown" (Lüthi 1987[1975]: 155), "a traveller [...] who transgresses boundaries" (Bacchilega 1997: 
141), a "homo viator" (Röhrich 2008[2002]: 102) constantly moving between two worlds (Tatar 2003[1987]: 61). In fact, only those characters who refuse to be "confined within the narrow boundaries of homeland" (Messerli 2005: 277) become the focus of narrative attention, while those who stay behind are typically forgotten. This is hardly surprising considering the fact that immobility traditionally connotes stagnancy and predictability (Leeuwen 2007: 23), which is not conducive to the fairy tale's focus on change and transformation.

To be sure, the significance of spatial transference extends well beyond the fairy tale. In fact, spatial transference in general - and the journey in particular - provides both a "model narrative" and the "model for narrative" (Mikkonen 2007: 286) for a large number of genres, such as the Arthurian romance (Vermette 1987) or the picaresque novel (Mickelsen 1981), to name but a couple. In fact, as Dean Duda points out, travelling and narrating are so closely intertwined they can almost be understood as synonyms (1998: 33). Michel de Certeau offers a similar point of view when he claims that "[e]very story is a travel story - a spatial practice" (1988[1980]: 115). While the significance of spatial transference as a model for structuring and means of propelling the plot forwards extends well beyond the fairy tale, what is specific to this genre is the fact that transference is a precondition for the encounter between the non-magical and the magical which, in turn, is a sine qua non of the fairy tale.

Although (as Chapter 4 will demonstrate) magical characters also engage in spatial transference, the aforementioned encounter between the non-magical and the magical is usually dependent on the protagonist, whose actions either enable the appearance of the magical within the non-magical (see Chapter 4) or constitute a departure from the non-magical domain (usually embodied in the space of home). To enable the contact with the magical, the story will come up with any excuse to prompt the protagonist's departure from home, from poverty and family conflict to various tasks and errands (Lüthi 1986[1947]: 16). The departure from home is exclusive to human, non-magical characters. This is largely predicated on the fact that the fairy tale typically focuses on human protagonists and begins in domestic, non-magical spaces. While magical characters are also mobile, their point of departure is usually not mentioned; rather, they simply appear within the nonmagical domain. In some cases, this is true of non-magical characters as well, as some stories begin after the departure from home has already taken place. In other words, the initial movement from home is omitted and the character is introduced as already uprooted and mobile. This is often the case in tales of discharged soldiers (e.g. "The Blue Light”, KHM 116, ATU 562; “The Worn-out Dancing Shoes”, KHM 133, ATU 306), whose "careers" as literary characters typically begin at the moment when their military careers have come to an end. Despite its absence from the 
narrative, the protagonist's departure from home prior to the events of the story is implied.

Despite being a crucial first step, spatial transference (typically manifested as the protagonist's departure from home) is not the only requirement for crossing the interdomain boundary. Consider the many older siblings of the KHM fairy tales who set off on quests but fail to enter the magical domain (e.g. "The Golden Bird", KHM 57, ATU 550; "The Three Feathers", KHM 63, ATU 402 ; "The Water of Life", KHM 97, ATU 551). Rather, characters who wish to enter the domain they are not endemic to must meet specific conditions which vary depending on the direction of the spatial transference. As the following chapter will demonstrate, these conditions, coupled with the possibility of crossing the interdomain boundary from both sides and the fact that this crossing is always temporary, set the fairy tale apart from other dyadic genres. 


\section{$4 \quad$ Crossing the Boundary between the Non-magical and the Magical}

The present chapter focuses on the second of the two main research questions posed by this dissertation: what can space tell us about fairy tales? Building on the category of the domain presented in the previous chapter, it asks what makes the interaction among the fairy-tale domains unique compared to other dyadic genres in the KHM. It proposes a threefold answer to that question: first, unlike other dyadic genres in which it is often the supernatural characters who can appear in the human domain at will, the interdomain boundary in the fairy tale can be crossed from both sides; second, the crossing of the interdomain boundary is always temporary, meaning that all the characters must return to their "native" domains by the end of the story; third, the crossing of the interdomain boundary is possible only if specific conditions are met. While its mode of realisation varies depending on the identity of the character engaging in spatial transference - i.e. whether a non-magical character is moving into the magical domain or vice versa - the main prerequisite for crossing the interdomain boundary is establishing contact with a character who is "native" to the target domain.

By engaging in spatial transference, characters come into contact with representatives of the opposite domain, thus creating an opportunity for crossing the interdomain boundary. However, despite being a crucial first step, spatial transference alone is not enough, as not all mobile characters are admitted into the target domain (the numerous older siblings in stories such as "The Griffin" or "The Three Feathers", who set off on quests but are ultimately unsuccessful, come to mind). Writing about human characters attempting to access non-human regions in various narratives, Doležel notes that they require "[s]pecial permits [...] granted only to selected humans for a definite purpose and under strict conditions" (1998: 131). Thus, only those who meet these strict conditions are granted permits allowing them to (temporarily) cross the interdomain boundary.

The first part of this chapter explores the means of (temporarily) overcoming the interdomain separation; specifically, it examines which side of the boundary initiates the contact between the magical (M) and the non-magical (N) and why, and how entry of the non-magical into the magical $(\mathrm{N} \rightarrow \mathrm{M})$ and the magical into the non- 
magical $(\mathrm{M} \rightarrow \mathrm{N})$ is negotiated. Moreover, it examines the nature and concrete manifestation of the aforementioned "strict conditions" the interdomain transference is predicated upon, and demonstrates that while "special permits" are necessary for any type of transference between the fairy-tale domains regardless of its direction, their nature differs considerably for non-magical and magical characters. The second part of the chapter highlights the unique features of the spatial structure and interaction between the two fairy tale domains by examining other dyadic genres featured in the KHM - specifically, didactic tales, legends, aetiological tales, and religious tales. As in Chapter 3, considering spatial issues in connection with dyadic KHM genres has led to a re-examination of their preliminary genre definitions, as well as a revision of the initial genre classification of our research corpus (see Appendix 2). This points to the significance of space as a narrative element that has the potential to increase our understanding of individual genres and their relationships.

\section{Moving from the non-magical into the magical $(\mathrm{N} \rightarrow \mathrm{M})$}

Crossing the interdomain boundary from the side of the non-magical $(\mathrm{N})$ into the magical $(\mathrm{M})$, i.e. the $\mathrm{N} \rightarrow \mathrm{M}$ spatial transference, can be initiated by both the nonmagical and the magical. In both cases, the stimulus stems from one domain's need of the other's assistance (regardless of which domain is in need, both will benefit from their interaction by the end of the story). Human protagonists typically seek magical assistance and/or entry into the magical domain because they are faced with a problem that cannot be resolved by human means. ${ }^{54}$ While the same underlying motivation leads to the appearance of the magical in the non-magical (see below), it is important to note that in this case, human protagonists actively and purposefully seek out the magical solution to their problem. In contrast, when the magical appears within the non-magical, it often responds to an unwittingly issued invitation. The magical will typically put the non-magical character to a test to determine whether they are worthy of assistance and, in many cases, admittance into the magical domain. Vulnerable protagonists fleeing from abusive environments are also in need of magical assistance, but do not actively or purposefully seek it. In some cases, it is the magical that initiates the encounter with the non-magical, luring human

54 Sometimes the characters themselves are aware that their problem can only be solved via magical assistance; for example, the heroine of "The Singing, Springing Lark" (KHM 88, ATU 425A) realises that she "won't be able to get help from a mortal", which prompts her to seek help in the magical, celestial realm (Grimm 2003[1857]: 294). 
characters into its midst because it wants to hurt them (malevolent magical) or because it needs their assistance (vulnerable magical). Although the means of and preconditions for the $\mathrm{N} \rightarrow \mathrm{M}$ transference differ for the three cases, their common denominator is the presence of a magical gatekeeper who either tests the human characters or lures them into the magical domain.

\section{Testing the protagonist}

Human characters in the KHM fairy tales who actively seek magical assistance and/or purposefully wish to engage in the $\mathrm{N} \rightarrow \mathrm{M}$ transference (a plot typical of quest or adventure fairy tales) must first prove their worth by passing a test. The testing is conducted by magical characters whose ability to either obstruct or facilitate the human characters' progress by denying or granting them magical assistance depending on their performance (cf. Laine 2000: 121), lends them the role of gatekeeper to the magical domain (Morphy 1995: 204). Thus, the tester figure rewards characters who pass the test by offering magical objects or guidance, and/or admitting them into the magical domain. Conversely, unsatisfactory performance on the test is punished by denying the unsuccessful candidate magical assistance. By establishing who will benefit from magical assistance, the test also determines the overall success/failure of individual characters as only those who are aided by the magical can obtain the coveted happily ever after. The test can refer to different qualities and/or abilities, most notably character traits (the test of merit) and observance of specific rules of conduct (Meletinskij et al. 1974[1971]: 79, 83).

To pass the test of merit, fairy-tale characters are often required to demonstrate qualities such as compassion, diligence, kindness, and generosity by, for instance, sparing/saving the life of an animal ("The Golden Bird"), doing household chores ("The Three Little Gnomes in the Forest", KHM 13, ATU 403; "Mother Holle"), or sharing food with a stranger ("The Golden Goose", KHM 64, ATU 571, 513B; "The Lettuce Donkey", KHM 122, ATU 567, 566). Occasionally, the tests appear in sets of two or three. This is commonly the case with tales belonging to or containing elements of the tale type ATU 554, The Grateful Animals, such as the Grimms' "The White Snake" (KHM 17, ATU 673, 554) or "The Queen Bee" (KHM 62). The protagonist comes across several animals who all put him (all the Grimms' tales of this type feature male protagonists) to the test by asking him to perform an act of kindness such as feeding them ("The White Snake") or sparing/saving their life ("The Little Hamster From the Water"). In return, the animals appear when the protagonist needs them the most and they perform difficult tasks, such as retrieving a lost person or object, gathering scattered grains, or finding a far-away object, on his behalf. 
It should be noted that, as Rina Drory (1977) has demonstrated, the nature of the tests and the behaviour/qualities needed to pass them are highly dependent on gender. Thus, female characters who prove to be diligent, obedient, polite, and magnanimous are rewarded, while lazy, disobedient, rude, and stingy ones are punished - often within the same story (tales of the ATU 480, The Kind Girl and the Unkind Girl type, such as "Mother Holle" or "Saint Joseph in the Forest", KHM 201). ${ }^{55}$ However, the same traits that bring punishment upon female characters are likely to ensure male characters magical assistance and protection. This is especially true of laziness and stupidity, ${ }^{56}$ common traits of the youngest male sibling in (the Grimms') fairy tales. ${ }^{57}$ Furthermore, female characters are often called upon to demonstrate loyalty to lost romantic partners, who temporarily forget about them and find new mates (e.g. "The True Bride", KHM 186; "The Drummer", KHM 193, ATU $400,518,313)$. Once they regain memory of their "true bride", the male characters do not have to face any consequences for betraying their romantic commitments. In contrast, female characters who abandon their partners (sometimes for not unjustified reasons) and seek new ones are punished by death ("The Three Snake Leaves"; "The King of the Golden Mountain", KHM 92, ATU 400). A female character on a quest to find a lost partner or sibling often has to prove her worth not (only) by performing an act of kindness, but by sheer persistence, loyalty, and determination. This typically means undergoing great physical exertion and persisting for prolonged periods of time ("The Singing, Springing Lark"). In contrast, male characters may be called upon to demonstrate their strength ("The Prince Who Feared Nothing", KHM 121, ATU 590), courage ("Bearskin", KHM 101, ATU 361), or even cunning ${ }^{58}$ ("The Drummer"), which is not the case with their female counterparts.

55 For a more in-depth discussion of this tale type, see, among others, Jason (1988) and Roberts (1958).

56 Schmiesing (2014) problematises the notion of stupidity in the Grimms' fairy tales by pointing to its subversive potential. Narratives in which the protagonist is nicknamed Dummy or Simpleton are especially ambiguous in this respect as it is not always clear whether the protagonist really is stupid or whether he is labelled as such by his environment (Schmiesing 2014: 165-170).

57 One exception to this rule is "The Three Spinners" (KHM 14, ATU 501), a tale in which the heroine's laziness not only goes unpunished but is actually rewarded with a royal marriage and the promise of a spinning-free existence. For Tatar, this attitude, coupled with the comedic tone and depiction of spinning as a tiresome activity, is a clear indication that the tale is actually a folk tale, rather than a fairy tale (2003 [1987]: 130). Male protagonist may obtain magical objects by outsmarting their dim-witted owners. This is usually the case in stories featuring giants or robbers who cannot decide how to divide magical objects among themselves (ATU 518, Men Fight over Magic Objects) such as "The King of Golden Mountain" or "The Drummer". 
Despite their prominence in the plot of the Grimms' fairy tales, (positive) character traits are not the only thing that dictates the outcome of the test. Thus, to ensure magical assistance, the protagonist is often required to simply follow certain "automatic rules" the story operates on (Drory 1977: 35). This means that punishment is not necessarily reserved for evil or selfish characters, but also for those who make a blunder by not following "the particular rules of the game" (Meletinskij et al. 1974[1971]: 79). For instance, in "The Three Little Birds" (KHM 96, ATU 707), two brothers politely greet the old woman they meet on their way to find their father. However, they also point out that she will not catch a fish any time soon, which elicits the following response: "And you'll be searching a long time before you find your father" (Grimm 2003[1857]: 326). As a result, both brothers end up wandering around the world, unable to find their father. In contrast, their sister wishes the old woman good luck with the fishing, which prompts her to provide the girl with directions and advice about her journey. The unspoken rules in "The Griffin" dictate that whatever the three brothers answer in response to the old dwarf's question will materialise. When the older brothers, who are not initially established as undeserving characters (unlike the brothers in "The Water of Life", they are not guided by selfish motives since it is their father who sends them to the king's castle with what he believes is a remedy for the sick princess), dismiss the inquisitive dwarf by misrepresenting the contents of their baskets, the thing identified in their answers (frogs' legs, hogs' bristles) appears in their baskets. In contrast, the simpleton Hans answers truthfully and is rewarded.

The importance of the test is narratively highlighted by contrasting positive and negative examples, and is often explained by the gatekeepers, who explicitly state that they are rewarding or punishing someone because they have (not) behaved properly: "since you've behaved yourself in a proper manner and are not arrogant like your faithless brothers, I'll tell you how to get to the Water of Life" (Grimm 2003[1857]: 328); "I see you have a kind heart [...] So, I'm going to grant you three wishes" (ibid.: 367); "Since you've been so kind, I'm going to give you a gift" (ibid.: 400), etc. Negative examples include both failing the test of merit and forcing the $\mathrm{N} \rightarrow \mathrm{M}$ transference. Forcing the encounter with the magical is typically punished: for example, Rapunzel's father who sneaks into the sorceress's garden and steals her vegetables is threatened by death, a sentence suspended only when he agrees to give her his child. Characters who prove unworthy by failing the test of merit are not only denied magical assistance, but also actively punished for their shortcomings. In "The Golden Bird", the older brothers who set out to find the titular creature become stuck at an inn because of their attempts to kill the helpful fox. In contrast, the youngest brother who proves kind and compassionate is transported into the magical domain and continuously aided in his quest. A similar fate befalls the older siblings in "The Water of Life", who are guided by purely selfish motives in their mission to find the 
miraculous fluid and act dismissively towards the helpful dwarf. As punishment, they are trapped inside a mountain gorge.

Contrasting positive and negative examples also serves to highlight that characters' success is predicated on magical assistance. This is especially evident in stories such as "The Three Feathers" or "The Poor Miller's Apprentice and the Cat" (KHM 106, ATU 402), in which three male characters (often siblings) compete for inheritance by trying to find the most beautiful object, animal, or bride. The characters who search "only in predictable arenas" (Tatar 2004a: 278, n.5) come up with lame/blind horses, unimpressive carpets, and plain brides; in contrast, the character who enjoys magical assistance comes out on top by presenting an exquisite horse, a "carpet so beautiful and fine that nobody on earth could possibly have woven it" (Grimm 2003[1857]: 234), and the most beautiful bride under the sun. Similarly, the two brothers in "The Little Hamster From the Water" who rely on themselves and hide from the all-seeing princess in the cellar and lime pit are quickly discovered, while the brother who is hidden by talking animals successfully completes the task. In cases discussed in this and the previous paragraph, the older siblings' failure serves to emphasise the importance of passing the test, as well as the impossibility of crossing the boundary between the domains at will and succeeding without the assistance or permission of the magical gatekeeper.

\section{Vulnerable protagonist}

Among the characters actively seeking out the magical, those who are successful are typically set apart from their environment in some way. While some possess exceptional qualities such as physical strength ("The Prince Who Feared Nothing"), most of them occupy a marginal position on the social ladder (discharged soldiers) and/or within the family unit (youngest child, stepchild). Others find themselves in vulnerable positions owing to domestic abuse ("One-Eye, Two-Eyes, and ThreeEyes") or unfair treatment on the part of larger social structures ("The Blue Light"; “The Devil's Sooty Brother", KHM 100, ATU 475). Moreover, characters often put themselves in vulnerable positions by getting lost in the woods and wandering around for prolonged periods of time without food, water, or any hope of finding a way out on their own.

While marginal characters are tested prior to receiving magical assistance, vulnerable characters who are victims of abuse or an unjust society often receive magical assistance without actively or purposefully asking for it. Thus, characters who run away from abusive step-parents like Snow White or the siblings in "Brother and Sister" (KHM 11, ATU 450) find shelter in the magical domain; similarly, the Virgin Mary offers to take a young girl to heaven to save her from poverty and hunger ("The Virgin Mary's Child"). Their vulnerable position makes characters 
who are lost in the forest susceptible to external stimuli, which is why the magical (whether motivated by benevolent or malevolent intentions) can easily lure them into its midst (see below).

Vulnerable characters do not have to pass a test (of merit) in order to gain magical assistance; rather, it is their very vulnerability that ensures them interaction with the magical. Despite the absence of a prerequisite test, such characters may be tested after they have received magical assistance and be called upon to prove that they deserve to stay in the magical domain. For example, the dwarfs are willing to let Snow White stay with them, but only if she promises to cook and do the housework; similarly, the Virgin Mary's protégé has to prove she is obedient, honest, and truthful when Mary entrusts her with the keys to all the rooms in heaven, and strict instructions to stay out of the last one.

\section{Luring the non-magical into the magical}

The $\mathrm{N} \rightarrow \mathrm{M}$ transference may also be initiated by the magical, which lures the nonmagical into its midst. The magical will lure a non-magical, human character for one of three reasons: 1) the magical needs help as it yearns to be "demarvelised" (Jason 1978: 27); 2) the magical wants to help the vulnerable non-magical character; or 3) the magical wants to harm the vulnerable non-magical character. The magical can lure non-magical characters by manipulating objects and animals, or using various visual and audio signals.

In stories such as "Mother Holle" or "The Frog King", the magical manipulates objects that belong to human characters, drawing them into the magical domain (cf. Jason 1988: 139). Thus, both the spinning wheel in "Mother Holle" and the golden ball in "The Frog King" fall into a well, prompting the heroines to either follow them ("Mother Holle") or bargain with the magical in order to retrieve them ("The Frog King"). A lost golden ball also initiates contact between the magical and the nonmagical in "Iron Hans" (KHM 136, ATU 314). Similarly, in "The Three Feathers", the two older, underserving brothers follow their feathers across the familiar, nonmagical domain, while the third brother is led to the entrance to the magical domain.

In some cases, animals lead human characters into the magical domain or to liminal spaces where magical characters are waiting for them. The KHM fairy tales frequently cast a stag/deer/doe in that role: the animal (sometimes an enchanted human; "The Glass Coffin", KHM 163, ATU 410, 552) is typically chased by a hunter who is thereby separated from his group (the character is always male). The manipulated animal is used with both good and evil intentions. In cases like "The Nixie in the Pond", "The Golden Children" (KHM 85, ATU 303), and "The Two Brothers" (KHM 60, ATU 567, 300, 303), the animal lures its pursuers into danger, bringing them into the hands of magical characters who wish to harm or - in the case 
of "The Two Kings' Children" (KHM 113, ATU 313) - put them to a test. On the other hand, in "The Glass Coffin", a magic deer (the heroine's enchanted brother) carries the protagonist to an enchanted cave where the sleeping heroine is waiting to be rescued.

While game is typically used to lure male characters, female and child characters are more likely to be led to the magical by birds. In "Hansel and Gretel", the lost siblings are guided to the gingerbread house by a "beautiful bird" with "a lovely voice" (Grimm 2003[1857]: 56). ${ }^{59}$ The birds in "The House in the Forest" (KHM 169, ATU 431) do not explicitly guide the three sisters to the titular location, but they nevertheless seem to be in the service of the magical. They eat the trail of seeds the father leaves for his daughters, causing them to get lost in the forest. The magical - embodied in the enchanted prince who longs to be free from a spell - proceeds to lure the lost girls with a light in the distance. Less frequent are other creatures who nudge the protagonist in the direction of the magical; for instance, in "Saint Joseph in the Forest", the girl's guardian angel plays an important role in her meeting with the magical. Normally, he is by her side, leading her safely home when her stepmother sends her into the forest, hoping to get rid of her; however, on one occasion, he pretends not to be there so the girl gets lost and is then lured towards the cottage by the light. An angel also appears to guide the protagonist of "The Maiden Without Hands" to a safe place in the forest, where she and her child are taken care of and where her severed hands magically grow back.

The magical also uses visual and audio signals to get the attention of non-magical characters and draw them into its midst. Visual signals typically include gestures and - most frequently - a light in the distance. Gestures are used to express a desire to communicate: in "The Crystal Ball", for instance, quarrelling giants wave to the protagonist, inviting him over, because they need his help to decide who is the rightful owner of a wishing hat. The most frequent visual signal in the Grimms' fairy tales is the light in the distance, which guides characters to a solitary cottage in the woods or a lit fire. The light is typically used to attract vulnerable characters who are lost in the woods, without food or company. This vulnerable position makes them respond positively to the appearance of a light and immediately head towards it, hoping they will find shelter. Frequently, the light-casting cottage proves to be a safe haven for the protagonists, who are allowed to spend the night there. While there, they receive magical assistance ("The Iron Stove", KHM 127, ATU 425, 425A) or are subjected to a test of merit ("Saint Joseph in the Forest"; "The House in the Forest"). The characters casting the light may also have malicious intentions: this is

59 In parallel, the siblings are transported back into the non-magical domain by another bird - this time a "kind little duck" summoned by Gretel's song (Grimm 2003[1857]: 58; see Goldberg 2000). 
the case with the witch in "The Blue Light", who wants to exploit the old soldier, or the giants in "The Expert Huntsman" (KHM 111, ATU 304), who are planning to attack a castle. However, in both cases, the protagonist manages to outsmart the malicious figures and turn the situation in his favour. In "The Devil With the Three Golden Hairs", the light comes from a non-magical but threatening source: a robbers' den. Even in this case, the situation turns in the protagonist's favour as the robbers take pity on him and help him avoid the death sentence.

Non-magical characters can also follow various sounds (music, voices, etc.) which bring them face to face with the magical. The magical may explicitly call out to the non-magical, seeking assistance, as in "The King of the Golden Mountain", where quarrelling giants invite the protagonist to come over and help them divide magical objects among themselves. In "The Glass Coffin", the reluctant tailor is encouraged by a disembodied voice to go below ground, where the enchanted count's daughter is waiting to be rescued. The miller in "The Nixie in the Pond" is drawn to a pond by a rushing sound; seeing the nixie rise from the water, he turns to run, but is persuaded to stay by "her soft voice" (Grimm 2003[1857]: 527). In "The Raven" (KHM 93, ATU 400, 518), it is the sound of the titular bird that leads the protagonist to the enchanted king's daughter, who asks for his help; similarly, the young scholar in "The Spirit in the Glass Bottle" (KHM 99, ATU 331) finds the enchanted bottle by following the pleading voice of the captured spirit. The enchanted bird in "The Juniper Tree" (KHM 47, ATU 720) uses its song to capture the attention of a series of craftsmen, who proceed to reward the unusual artist with a pair of shoes, a golden chain, and a millstone.

When human characters actively seek out the magical (typically to complete a quest by retrieving a magic object or rescuing an abducted bride), they must prove they are worthy of magical assistance by passing a test of merit (conducted by the magical gatekeeper) or following certain "automatic" rules. Vulnerable characters receive magical assistance without actively pursuing it, but may be asked to demonstrate their worth afterwards. When the contact is initiated by the magical, this is done in order to provide the non-magical with assistance (the benevolent magical), seek assistance from it (the vulnerable magical), or try to harm it (the malevolent magical). Regardless of its motivation, the magical lures the non-magical into its midst by manipulating objects or animals, or using visual or audio signals. A common factor in all these cases is the active role of the magical, which tests the non-magical characters or manipulates them into crossing the interdomain boundary. When the magical crosses into the non-magical $(\mathrm{M} \rightarrow \mathrm{N}$ spatial transference), a different set of conditions is in place. 


\section{Moving from the magical into the non-magical $(\mathrm{M} \rightarrow \mathrm{N})$}

According to Heda Jason, only human characters in fairy tales are free to move between the domains, while their magical counterparts are bound to their own domain (1988: 82). Lotman makes a similar observation in his discussion of the boundary separating the home and the forest - which he sees as the basic spatial division in the fairy tale - when he notes that " $[\mathrm{t}]$ he personae of the forest cannot enter the home; they are allowed a definite space" (1977[1970]: 230). The present research challenges these claims, arguing that the interdomain boundary in fairy tales can be crossed from both sides; thus, magical characters can enter the non-magical in order to help deal with a problem that cannot be solved via non-magical means (supportive, benevolent magic) or cause harm (disruptive, malevolent magic). As with the $\mathrm{N} \rightarrow \mathrm{M}$ transference, the crossing of the interdomain boundary from the side of the magical can be initiated by both the magical and the non-magical, is dependent on certain conditions, and requires establishing initial contact with a non-human gatekeeper. However, the role of the non-magical is not to test or lure the magical, but rather to summon it - sometimes intentionally, sometimes unintentionally. The $\mathrm{M} \rightarrow \mathrm{N}$ transference is therefore initiated by and performed at the behest of human characters. Unlike their magical counterparts whose actions are deliberate and purposeful, non-magical gatekeepers often act in ignorance, unaware that their actions may lead to the appearance of the magical. In contrast, the disruptive magical does not hinge on non-magical permission, forcing its way into the non-magical domain.

\section{Verbal summons}

The non-magical typically reaches out to the magical (intentionally or unintentionally) in moments of great need and heightened emotions, which can be expressed in a verbal and/or non-verbal manner. The distress is typically generated by a situation in which a non-magical character is faced with a task or problem that cannot be solved via non-human means, such as drying up a lake with a leaky spoon or building a castle in one day ("The True Bride"), chopping down a forest with a lead axe ("The Drummer"), or turning straw into gold ("Rumpelstiltskin"). In addition to impossible tasks, difficult situations such as domestic abuse, hunger, or inability to conceive can also be a source of great distress. The expression of distress, which can manifest itself in a verbal or non-verbal manner, serves to establish contact with and (unwittingly) summon the magical (cf. Lüthi 1986[1947]: 14), which responds by penetrating the non-magical domain, often in the shape of a magical helper. Verbal summons can take the form of an invitation, permission, marital vows, a (reckless) wish, verbal formulae (spell), an explicit cry for help, or 
other verbal expressions of helplessness. Non-verbal summons, which appear independently or in combination with verbal ones, include various expressions of helplessness and heightened emotional states, such as crying, throwing one's hands up in desperation, or abandoning all activities which are perceived as futile.

Less frequently, magical creatures in the KHM tales receive explicit invitations or are explicitly granted permission to enter the non-magical. Probably the most famous fairy-tale invitation (and one with the direst consequences) is issued to the twelve wise women in "Brier Rose", who are kindly asked to attend a feast in honour of the new-born princess. The absence of an invitation becomes a kind of invitation in its own right, as the offended thirteenth fairy penetrates the non-magical, seeking revenge. In "Snow White and Rose Red" (KHM 161, ATU 426), the enchanted bear knocks on the door of the titular sisters' cottage, kindly asking permission to come in and warm himself; once the mother openly invites him to lie down by the fire, the magical bear enters the non-magical space of the cottage.

However, the permission or invitation may also be elicited under false pretences, as evidenced by "The Glass Coffin", a story in which the children of a rich count allow an evil magician to stay in their castle, mistaking him for a lost traveller. Thus, the magical (antagonists) may manipulate non-magical characters into an interaction, typically with the intention of kidnapping or otherwise harming them. In 'Fitcher's Bird", for instance, the evil wizard tricks the three sisters into opening the door to their home (thus symbolically erasing the interdomain boundary) by pretending to be a beggar. By (physically and symbolically) opening the door to the non-magical, the girls become exposed to the influence of the magical: as soon as the wizard touches them, they are transported into his basket and taken to his castle. It is important to note that the wizard does not enter their home and can only cast his spell once the girls open the door to him, thus symbolically inviting the magical inside. ${ }^{60}$ In addition to soliciting an invitation under false pretences, the magical may force its way into the non-magical in an act of theft and/or kidnapping (e.g. the dragon kidnapping the princess in "The Four Skillful Brothers", KHM 129, ATU 653). Less frequent in the KHM tales, such intrusive acts are always severely punished.

The human gatekeeper allowing the magical access into the non-magical may also be the romantic partner of the magical character, who is granted (permanent) access into the non-magical domain by marrying the gatekeeper. In cases like this, the marital vow acts as the summons, i.e. an invitation and permission to enter the non-magical domain. In the Grimms' fairy tales, it is typically the male characters who marry women in possession of magical abilities (witches, sorceresses). The

60 This is reminiscent of beliefs related to various supernatural beings - most notably vampires - according to which the supernatural cannot enter the home unless explicitly invited/granted permission to do so (cf. Gelder 1994: 16, 35). 
witch/sorceress may be brought into the non-magical household in the course of the story ("Snow White") or introduced as the new mistress of the household and stepmother to the fairy-tale hero/ine from the very beginning ("Brother and Sister"). Even when the story does not depict her arrival in the non-magical house, it is clear she is an outsider who was brought into the domestic arena by an inhabitant of that household (the husband). "The Six Swans" (KHM 49, ATU 451) provides a rare depiction of the encounter between the human gatekeeper and his future magical wife, one in which the human character (the king) is first lured into the magical domain (he follows a deer and gets lost in the forest) and is then manipulated into granting the magical permission to enter the non-magical (an old witch promises to show him the way out of the forest if he marries her daughter). It should be noted that marital vows also present only a temporary permission for the magical to appear and exist within the non-magical, as stories featuring the marriage between a nonmagical male character and witch/sorceress typically end with her death (e.g. "Brother and Sister", "Snow White").

A frequent means of unwittingly granting the magical entrance into the nonmagical is the (reckless) wish, which (at least in the KHM) typically results in the birth of non-human children, ${ }^{61}$ such as the titular Hans the Hedgehog, or the transformation of human children into animals ("The Seven Ravens", KHM 25, ATU 451; "The Raven"). The wish can be explicitly stated (e.g. "I want to have a child, even if it's a hedgehog", Grimm 2003[1857]: 361; "Oh, if only we had a child!", ibid.: 171) or implied via lamentations about one's current situation (e.g. "The queen lamented day and night [...] saying, 'I'm like a field on which nothing grows"'; ibid.: 456). Verbalising the wish to have a child - even one that is miniature in size or looks like an animal - is triggered by a state of heightened emotions, caused by a problem for which the non-magical domain cannot provide a solution. As such, it serves as an invitation for the magical to (symbolically and temporarily) cross the interdomain boundary and enter the non-magical. Reckless wishes are also uttered in anger, as evidenced by the king in "The Seven Ravens", who sends his sons to fetch water for the baptisms of their new-born sister. Afraid that the sickly baby might die before she is baptised, the king curses his sons' lack of speed: "Those wicked boys must have forgotten what I sent them to do! They're probably playing games again. [...] I wish those boys would all be turned into ravens!" (ibid.: 91). Similarly, the queen in "The Raven" loses patience with her misbehaved daughter: "I wish you were a raven and would fly away! Then I'd have my peace and quiet"

61 Ann Schmiesing provides novel and insightful readings of such "monstrous birth tales" (2014: 20) from the point of view of disability studies. 
(ibid.: 315). In both cases, the magical immediately responds by transforming the children into birds. ${ }^{62}$

Various verbal formulae such as spells and chants can also serve as invitations to the magical to penetrate the non-magical domain. Fairy-tale heroines (sometimes unknowingly) use verbal magic, which typically consists of an explicit invocation of the magical force and a command (Bottigheimer 1987: 41), to activate the magical properties of objects and/or ensure magical assistance. In "Cinderella", a chant summons the pigeons who perform the impossible task of collecting all the scattered peas and prompts the hazel tree growing on her mother's grave to supply the heroine with apparel for the ball; in "The Goose Girl" (KHM 89, ATU 533), a chant gets the wind to blow away the inquisitive shepherd's hat, thus ensuring privacy for the heroine who wants to comb her golden hair in peace. In "Spindle, Shuttle, and Needle" (KHM 188, ATU 585), the heroine activates the magical properties of the titular objects by repeating spells she heard her (magical) godmother utter while working, while Gretel in "Hansel and Gretel" uses a chant to attract the attention of a duck and convince it to carry her and her brother across the river. Heroines in "OneEye, Two-Eyes, and Three-Eyes" and "The Sweet Porridge" (KHM 103, ATU 565) repeat incantations learned from kindly older women to activate the magical properties of objects within non-magical spaces. With some exceptions (e.g. Ferdinand Faithful addressing the huge birds and giants with a special incantation; "Faithful Ferdinand and Unfaithful Ferdinand"), incantations are reserved for female protagonists, who often learn them from older women (e.g. the godmother in "Spindle, Shuttle, and Needle") and use them to command natural powers, such as animals, wind, or trees.

The realisation that they will not be able to solve a problem they are facing or perform a task they have been given by relying solely on themselves may prompt fairy-tale characters to verbalise their desperation. Tasked with finding the king's lost sweetheart, Faithful Ferdinand laments his fate in front of his horse: "Oh, what an unlucky person I am! [...] Oh, my dear little white horse, I must leave you now, I'm going to my doom" (Grimm 2003[1857]: 413). This serves as a kind of trigger for the magical, as the horse suddenly reveals he can speak and knows exactly what Ferdinand needs to do to complete his quest. The knowledge that she cannot strip the quills off twelve pounds of feathers in time and will therefore be severely

62 Not all wishes featured in the KHM fairy tales are reckless nor are they all uttered within the non-magical domain. For instance, while roaming the forest, the hero of "The Knapsack, the Hat, and the Horn" (KHM 54, ATU 569) wishes for something to fill his stomach with; the magical responds by providing him with a table laden with food. Similarly, the drummer who wishes to find himself atop the glass mountain quickly acquires the means to do so ("The Drummer"). 
punished makes the heroine of "The True Bride" cry out: "Is there no one on God's earth who will take pity on me?" (ibid.: 538). The cry is immediately answered by the comforting words of a magic helper: an old woman who performs all the difficult tasks for her. In religiously intoned fairy tales, the cry for help takes on the form of a prayer: for instance, realising she cannot enter the royal garden filled with fruit trees, the hungry heroine of "The Maiden Without Hands" falls down on her knees and prays. An angel immediately appears and helps her enter the garden.

\section{Non-verbal summons}

The most common non-verbal means of summoning magical assistance in the Grimms' fairy tales is crying. Tears in the KHM tales almost immediately bring about the appearance of a magic helper. Faced with the impossible task of turning straw into gold, the miller's daughter in "Rumpelstiltskin" starts crying, which prompts the appearance of the eponymous helper. Similarly, the enchanted amphibian in "The Frog King" climbs out of the well, claiming he was drawn by the princess's cries: "What's the matter, Princess? Your tears could move even a stone to pity" (Grimm 2003[1857]: 1). On more than one occasion, the heroine of "OneEye, Two-Eyes, and Three-Eyes" cries "so much that two little brooks flowed from her eyes" (ibid.: 424); her tears serve to summon a helpful old woman, who alleviates the heroine's difficult domestic situation by instructing her what to do. Male protagonists cry as well: the hero in "The Two Kings' Children" sits down and cries, knowing full well he will be put to death because he is unable to cut down a forest using glass tools.

Frustration with an impossible task can lead to negative thoughts and the begrudging acceptance of one's fate, often expressed by simply sitting down and/or throwing one's hands into the air. For instance, the protagonist of "The Drummer" recognises the futility of his attempts to empty a pond with a thimble: "It's just the same whether I work or not. So he gave it up and reclined on the ground" (Grimm 2003[1857]: 560). As soon as he comes to terms with his own, non-magical limitations, a magic helper appears and performs all the work for him. In "Bearskin", the discharged soldier who lost his parents and was put out by his brothers sits down amidst a large heath, overcome by sadness and helplessness: "I have no money, he thought, I've learned nothing but how to use weapons, and now I'm not needed because peace has been announced. I already see that I'm bound to starve" (ibid.: 340). The magical - embodied in the devil - responds by offering him a lucrative deal.

The symbolic rift which the (non-)verbal summons creates in the boundary between the non-magical and the magical domain is sometimes accompanied by its physical erasure, achieved by the simple act of opening a door or window. The 
Grimms' "Cinderella" and "The Raven" both feature a double invitation to the magical, which includes the physical act of creating an opening in the boundary separating the non-magical (in both cases also the domestic) and the magical, as well as verbal formulae (Cinderella's song, the queen's reckless wish for her child to turn into a raven and fly away). In both stories, this combination proves efficient as the magical enters the domestic arena, whether physically (in the form of birds ready to help Cinderella) or by triggering the desired transformation (the queen's child turns into a bird).

The $\mathrm{M} \rightarrow \mathrm{N}$ transference may also take on the form of magic objects being imported into and used in the non-magical domain; such objects never originate within the non-magical and therefore must be introduced there by non-magical characters, which further highlights the importance of establishing a connection with a native character of the target domain. Consider the case of "The Lettuce Donkey": the effects of the magic object (the bird's heart consumed by the protagonist) are evident within the non-magical, domestic space, where the protagonist finds a gold piece under his pillow every morning. However, the object itself is initially obtained in the liminal space of the forest (following tips provided by the magic helper) and subsequently introduced into the non-magical domain by the human protagonist. Similarly, the magic pot in "The Sweet Porridge" works within the non-magical space, but does not originate there; rather, it is imported into it by the heroine, who receives it from a magic helper.

While it does eventually lead to positive outcomes and a happily-ever-after for the human protagonist, the magical appearing in the non-magical often creates problems for the human characters who unwittingly summon it. Rumpelstiltskin and the thirteenth wise woman in "Brier Rose" try to harm the protagonists by demanding their children as reward for their help, or putting a curse on them, respectively. The birth of "monstrous" children - the result of the magical penetrating the non-magical - similarly creates discomfort and annoyance in their surroundings, so that they are eventually forced to leave: ${ }^{63}$ Hans the hedgehog, whose father is mortified by his existence and wishes him dead, leaves his place behind the stove and goes into the forest. The birth of the donkey prince is initially met with similarly negative reactions: his mother screams and orders that he be thrown into the water ("The Donkey”, KHM 144, ATU 430). The donkey himself is equally distressed when he sees his reflection for the first time and subsequently decides to go out into the world.

The $\mathrm{M} \rightarrow \mathrm{N}$ transference can be initiated by both the magical and the nonmagical. Acting purposefully and often malevolently, the magical can obtain

63 Thumbling ("Thumbling", "Thumbling's Travels") is an exception to this rule: even though he is miniature in size, the parents accept that he is just the way they wished him to be, and love and care for him. 
permission to enter the non-magical under false pretences or simply force its way in. The non-magical typically issues an unintentional summons to the magical, which responds by entering the non-magical domain. The summons - which can be verbal or non-verbal - is usually an expression of emotional distress caused by a difficult situation which cannot be resolved by non-magical means. When faced with infertility or an impossible task, the protagonist is likely to cry, sit down and admit defeat, call out, or make a (reckless) wish, all of which function as summons. Moreover, the magical can be explicitly invited or granted permission to enter the non-magical. The invitation may take on the form of a proposal, wherein a nonmagical male character marries a witch or sorceress.

\section{Exceptions}

While the specifics of the conditions for establishing contact between the magical and the non-magical, and crossing the interdomain boundary, differ significantly depending on whether the mobile character is magical or non-magical, and whether the initiative for interaction comes from the magical or the non-magical side, their main purpose is the same: to establish a connection with and receive assistance from a character who is native or endemic to the target domain (i.e. a gatekeeper). However, not all the tales in our corpus which have been (re)classified as fairy tales (see Appendix 2) follow these rules. This is especially true of humorously intoned fairy tales (initially categorised as Schwank tales) such as "A Tale About the Boy Who Went Forth to Learn What Fear Was" (KHM 4, ATU 326), "The Brave Little Tailor" (KHM 20, ATU 1640, 1051, 1052, 1060, 1062, 1115), "The Clever Little Tailor" (KHM 114, ATU 850, 1061, 1159), and "The Giant and the Tailor". "A Tale About a Boy" and "The Brave Little Tailor" both feature protagonists whose success is not the result of magical assistance and who do not engage in any of the previously described types of interaction with the magical. Rather, they cross the interdomain boundary at will, without suffering negative consequences usually reserved for those who forcefully penetrate the domain they are not endemic to. The same can be said of "Thumbling" and "Thumbling's Travels", which, although establishing initial contact with the magical via verbal summons (wish) do not end with the disenchantment (demarvelisation) of the magical like other "monstrous birth tales", nor do they depict the social rise of the miniature protagonist. Does this mean these stories do not belong in the category of fairy tales? This research argues that the answer to this question is negative: these narratives are fairy tales, but given their humorous (parodic) traits, they uphold only some of the traditional genre conventions (e.g. the existence of two domains), while inverting others (e.g. necessity of magical assistance, the preconditions for interaction between the magical and the non-magical). 
"A Tale About the Boy Who Went Forth to Learn What Fear Was", "The Brave Little Tailor", and "The Clever Little Tailor" all follow the rags-to-riches plot trajectory typical of the fairy tale, and feature a number of themes and motifs commonly associated with the fairy-tale genre, such as going on quests, competing for the hand of the princess, marrying into royalty, and interacting with the magical. However, in a development atypical for the genre in which characters usually "get what they want by not doing anything themselves to achieve it" (Nodelman 2008: 48, emphasis added), they succeed by relying on themselves, rather than magical assistance: the boy defeats terrifying creatures because he is not frightened by them, while the two tailors use their wits to overcome larger and stronger opponents (giants, bear, boar, unicorn). While magical occurrences and characters in all three tales point to the existence of two domains, the interaction of the magical and the non-magical is not dependent on the conditions outlined above.

Rather than bring the findings presented above into question, the absence of the conditions the interaction between the magical and the non-magical hinges on may be ascribed to Schwank - or more specifically, parodic - elements present in all three narratives. Thus, they are all characterised by a discrepancy between genre conventions (heroic protagonist, successful accomplishment of impossible tasks, winning the hand of a princess, overcoming magical obstacles) and their realisation, between what Frederic Jameson terms the narrative's syntactic (the fairy tale) and semantic features (a comic tone typical of the Schwank; 2006[1981]: 93), which generates a humorous incongruity. This incongruity suggests that the tales may be viewed as parodies, narratives that rely on comic, exaggerated imitation of a genre, literary style, or individual work (Cross 2008: 66). Linda Hutcheon defines parody as "repetition with critical difference" (1985: 7), the "critical difference" manifesting itself as an exaggeration or even outright mockery of individual elements, or a deliberate, humorous inversion of conventions and expectations (Wehse 2001: 577). Parodic fairy tales - also referred to as mock, burlesque, farcical (Röhrich 1991[1956]), or carnivalesque tales (Jason 1977b) - often create comic incongruity by substituting magical elements with non-magical ones, such as sheer luck, wit, or trickery. This is the case with the narratives under discussion, which feature protagonists who do not benefit from magical assistance but rely on their wit and/or good fortune. Furthermore, the narratives substitute the heroic protagonist of the quest fairy tale with the numskulls and tricksters typical of the Schwank: with his inability to understand figurative language and differentiate between the realistic and the (apparently) supernatural, and even between the living and the dead, the boy who wants to learn what "the creeps" are has much in common with the numskull, while the little tailors who use their wit to triumph over stronger and more powerful individuals are akin to the character of the trickster (cf. Hyde 1998). 
Each of the three narratives parodies specific types and tropes of the fairy tale: "The Brave Little Tailor" uses the figure of a deceitful braggart who outwits giants to invert the tropes of the giant slayer tale, especially its fearless protagonist, who uses strength and courage to battle giants. "The Clever Little Tailor" parodies fairy tales such as "The Little Hamster from the Water" and "The White Snake", in which suitors must pass impossible tests to win the hand of the princess. In "The Little Hamster", only the suitor who enjoys magical assistance successfully passes the princess's test, while those who try to do so by relying on their own ingenuity are killed; in contrast, the clever tailor succeeds precisely by using his wit. The episode in the haunted castle in "A Tale About a Boy" is a parody of the tale type ATU 401A, Enchanted Princesses and Their Castle (Uther 2013[2008]: 9), which requires the protagonist to spend three nights at a cursed location and demonstrate his ability to refrain from doing something, such as making a sound or falling asleep.

The parodic tendencies of the three narratives also extend to the interaction between the magical and the non-magical. Thus, each narrative depicts a mock test of merit, which does not serve to demonstrate the protagonists' kindness nor does it ensure them magical assistance. For example, while spending the night under the gallows, the fearless boy feels sorry for the corpses hanging there and, worried that they might be freezing, cuts them down and brings them closer to the fire. However, the seeming demonstration of kindness and compassion ultimately serves as confirmation of the protagonist's stupidity (he cannot tell that his companions are corpses); the episode thus inverts the test of merit as the boy's kindness is misdirected and wasted on corpses. This links him to the sympathetic fools of the Schwank who feel sorry for rocks and cracks in the road, and try to help them by putting cloaks around them or filling them with butter (Thompson 1977[1946]: 191). Furthermore, the boy's positive traits do not bring about any benefits; on the contrary, he ends up extremely irritated by his companions who would not talk to him and prove to be "so stupid" (Grimm 2003[1857]: 13) they let their clothes catch fire (cf. Kujundžić, forthcoming). Similarly, the brave tailor misconstrues the mundane act of swatting flies for a demonstration of extraordinary strength and courage. When put to an actual test of strength and courage, he relies on his wits and uses various tricks to create the illusion that he actually possesses the tested qualities. "The Giant and the Tailor" begins in a similar vein as the boastful tailor roams around the world, looking for work. He soon encounters a terrifying giant, who demands that the tailor serve him; in a humorous inversion of the test of merit, the tailor performs all sorts of tasks for the giant (bringing him water, chopping wood) while at the same time boasting he could do so much more ("Wouldn't it be better if I brought you the entire spring right away along with the entire well?", "Wouldn't it be better to chop down the entire forest with one stroke"; Grimm 2003[1857]: 533, 
534). However, his ruse proves to be too successful, as the stupid giant becomes genuinely frightened and launches the tailor into the air.

"Thumbling" begins in familiar fairy-tale fashion, with a summons to the magical in the form of a (reckless) wish. The magical responds to the parents' longing for a child, even a miniature one, by entering the non-magical and granting their wish. The tiny hero becomes the focus of the story which, however, does not depict his disenchantment but a series of (mis)adventures which bring wealth to his parents. Both "Thumbling" and "Thumbling's Travels" are multi-episodic and almost "serial-like" as each episode serves primarily to illustrate the titular character's wit and resourcefulness (Apo 1995: 58). However, his size lends his adventures a comic tone and inverts the tropes of the traditional quest narrative: instead of covering large distances to enter the magical domain, Thumbling's adventures unfold across a more modest geographical scope and include hiding in a mouse hole, tricking robbers, and outwitting a wolf who swallowed him. Because of his size, the everyday environment becomes a source of all sorts of dangers; however, he ultimately succeeds not by relying on magical means (he himself can be seen as a magical character) but, like the previously discussed tailors and the fearless boy, by relying on himself and using his size to his advantage (cf. Schmiesing 2014: 151). As such, the Thumbling stories also function as parodies of the heroic adventure tale. This is especially evident in "Thumbling's Travels", which initially establishes its protagonist as a courageous adventure-seeker armed with a weapon (a darning needle posing as a sword). Ultimately, Thumbling engages in adventures simply for the sake of adventures and his ordeals do not bring about his disenchantment nor enable his social rise. What is more, "Thumbling's Travels" subverts the typical fairy-tale ending and reward by portraying a returning hero who brings home a single kreuzer, calling it "a tidy sum of money" (Grimm 2003[1857]: 154). Instead of material gain, his happy ending primarily consists of returning to the safety of home, where he is warmly welcomed by his loving parents.

The seemingly problematic narratives in our revised corpus of fairy tales were all initially classified as Schwank tales, which feature a number of elements typical of traditional fairy tales, such as the social rise and happy ending for the protagonist, appearance of magical creatures and events, and existence of two domains, while lacking others. Most notable among the absent elements are the protagonist's reliance on magical assistance, and the special conditions which this research has identified as definitive of the magical-non-magical interaction and the crossing of the interdomain border. However, rather than dismiss with these elements altogether, the humorous narratives acknowledge their importance for the genre by subverting them. For example, the test of merit, being a frequent means of establishing which character is worthy of magical assistance and/or admittance into the magical, proves futile (the fearless boy's act of kindness brings him nothing but frustration) or 
produces faulty results (the acts of both the clever and the brave little tailor do not actually demonstrate strength, merely the illusion of it). This highlights the notion that no single definition or set of traits can fully accommodate every single member of a given genre category.

\section{Fairy tale vs. other dyadic genres}

As stated in the introduction to this chapter, the present research argues that the genre-specific (if not genre-defining) feature of fairy-tale space is not the existence of the non-magical and magical domains, but their clear separation, as well as the means for their interaction and negotiation of the boundary between them. The research has identified three features of the interdomain boundary which appear to be a constant of the genre: 1) it can be crossed from both sides; 2) the boundarycrossing is always temporary, meaning that the mobile characters have to return to their endemic domain by the end of the story; and 3) boundary-crossing is predicated on specific conditions, primarily establishing initial contact with a character who is native to the target domain. However, while these features are certainly characteristic for the (KHM) fairy tale, this section asks whether or not they are also unique to it, setting it apart from other dyadic genres? To answer this question, the section will discuss each of the three spatial features separately and use them as the basis for comparing the fairy tale to other dyadic short prose narrative genres featured in the KHM. Specifically, the discussion encompasses didactic (cautionary) tales, religious tales, legends (demonological and religious legends), and aetiologies, as well as their Schwank sub-types. Before discussing each of these genres in connection to the three features of the fairy tale, the section first provides a definition and brief overview of their key features.

\section{Dyadic genres of the KHM}

As their name suggests, didactic tales are broadly defined as narratives intended to instruct the audience, especially in terms of how (not) to behave (see, for example, Hameršak 2011; Kujundžić 2012a: 183-186, 2016; Tatar 1992; Wilkie-Stibbs 2004[1996]). A prominent place among the KHM didactic tales belongs to cautionary or warning tales, which rely on negative examples to communicate lessons regarding (in)appropriate behaviour (Kvideland 2005: 190-191). The protagonists therefore serve as models of negative behaviour, i.e. embodiments of unacceptable traits such as disobedience, which are severely punished (often by death) in order to discourage the audience from following their example. For example, the "stubborn and curious" little girl in "Mother Trudy" who never obeys her parents ends up transformed into a log and cast into the fire (Grimm 2003[1857]: 
147). By relying on what Marc Soriano terms the pedagogy of fear (1969: 30), cautionary tales aim to scare their audience into obedience. They typically present home in idyllic terms, as a safe and familiar world which should never be abandoned or exposed to harmful external influences; in contrast, the "world", or non-home, is a perilous place populated by all manner of predators, such as wolves ("The Wolf and the Seven Young Kids"; "Little Red Cap", KHM 26, ATU 333) and witches ("Mother Trudy"). To move from the safety of home into the perilous forest or open the door to malevolent outsiders is to perform an act of transgression and break parental rules. This type of behaviour is always punished, which serves to underline the message that the world is a dangerous place, especially prominent at the time when cautionary tales presumably originated and when children were in danger of wandering off into forests, swamps, and other perilous sites (Soriano 1969: 27).

The status of didactic tales as an independent genre is somewhat problematic from the point of view of domains. Although not considering the spatial component, other scholars have also pointed out that didactic tales may not necessarily be a genre in their own right, as virtually any narrative has didactic potential: even in tales or novels that are not explicitly (or perhaps even deliberately) didactic, the fact that some characters come out on top while others are ultimately unsuccessful or even mocked for their actions or traits, can be seen as a means of promoting/condemning certain values and/or character traits (Stallcup 2012: 44-46). This is especially prominent in the case of the KHM, as a significant portion of the Grimms' editorial interventions were guided by the wish to turn their book into a "moralizing and socializing instrument" (Warner 1995: 14) by encoding individual tales "with morals, messages, and lessons in etiquette" (Tatar 2004a: 143, n.3). Thus, some degree of didacticism (including religious instruction) - whether implicit or explicit, inherent or superimposed - is found in a large number of their tales, regardless of genre. Even formula tales which are seemingly uninterested in anything other than the repetition and accumulation of episodes, characters, etc. may be said to have some didactic potential. For instance, since the titular event in "The Death of the Hen" is a direct result of the Hen's refusal to share a kernel with the Rooster, the tale may, to some extent, be interpreted as a warning against greed and selfishness.

Spatial structure seems to support this approach, as - similar to the previously discussed Schwank - the Grimms' tales commonly designated as didactic, such as "The Wolf and the Seven Young Kids", "Little Red Cap", or "Mother Trudy", differ in the number of domains. On the one hand, tales such as "Mother Trudy" translate the safe/dangerous juxtaposition onto the level of domains, with the safe space of home belonging to the human domain and Trudy's dangerous forest - home to various supernatural creatures and the site of supernatural transformations - to the supernatural domain. On the other hand, tales such as "The Wolf and the Seven Young Kids" unfold within the single non-human domain of the animal tale, in 
which both the man-made village and the dangerous nature from which the wolf comes are populated by anthropomorphic animals. This would suggest that didactic tales should not be considered as an autonomous genre, but rather as a literary mode, a subtype of other genres, such as the animal tale ("The Wolf and the Seven Young Kids"), fairy tale ("Little Red Cap") or legend ("Mother Trudy"), whose spatial structures they assimilate. In the case of the cautionary tale, the central dichotomy between the permitted and the prohibited merges with the dominant spatial dichotomy of a given genre, such as the man-made/natural space of the animal tale ("The Wolf and the Seven Young Kids").

As their name suggests, religious tales are intended to promote religious values and moral principles, as well as the belief in the sanctity and power of sacred figures (Bošković-Stulli 1963: 12). By promising a blissful afterlife that will compensate for all the troubles endured during one's earthly existence, these narratives offer consolation to those suffering material and/or emotional distress (Tatar 2004a: 383384). Unlike legends which are permeated by a fear of death, religious tales remind their audience that, while inevitable, death should not be a source of fear or distress because it brings repose from earthly hardship and deprivation ("God's Food", KHM 205, ATU 751G*), loneliness and pain ("The Little Old Lady", KHM 208, ATU 934C). Furthermore, it is part of God's greater plan, which is not always comprehensible to humans, but should nevertheless be embraced without question (Röhrich 2008[2002]: 30). Religious tales are also characterised by a strong didactic undercurrent: since the coveted eternal bliss in the afterlife cannot be obtained by everyone but is reserved for pious, selfless individuals, these narratives instruct the audience how to behave in order to achieve it (ibid.: 229). Especially prominent in this respect are narratives about reformed sinners, such as "Poverty and Humility Lead to Heaven" (KHM 204) and "The Three Green Twigs" (KHM 206, ATU 756A), which use fictional examples to depict (un)desirable traits and behaviours that are to be avoided or adopted in order to obtain a place in the afterlife.

The central message of "Poverty and Humility Lead to Heaven" is contained in the very title and further elaborated through the story of a wealthy young prince who willingly shuns all his worldly possessions in order to gain eternal life. The fact that the protagonist renounces his position at the very top of the social ladder for one at the very bottom, trading his "magnificent coat" for a "beggar's garment" (Grimm 2003[1857]: 588) adds to the gravity of the sacrifice. "The Three Green Twigs" shows that even those who do their best to stay on the straight and narrow path may occasionally go astray: thus, the pious hermit who passes judgement on a sinner immediately falls out of God's grace. The narrative subsequently follows his attempts to redeem himself by leading a life of deprivation and suffering, much like the prince-turned-beggar in "Poverty and Humility". Ultimately, not only is the hermit pardoned, but his fate prompts two wicked robbers to mend their ways as 
well. With their positive portrayal of death and instructions on how to earn a place in the afterlife, religious tales focus on achieving happiness in the next world, rather than this one. "The Poor Man and the Rich Man" (KHM 87, ATU 750A) promotes (un)desirable character traits by using positive and negative examples: the poor but pious man who generously offers the wandering beggar (the Lord himself in disguise) shelter is rewarded with both earthly bliss (a new house, guaranteed daily bread and health) and heavenly (eternal salvation), while the dismissive and greedy rich man who turns the beggar away and later squanders his wishes ends up with "nothing but irritation, trouble, and abuse from the wishes" (Grimm 2003[1857]: 292). In addition to teaching through examples, religious KHM tales also offer explicit religious instructions and morals. The parable "The Sparrow and His Four Children" (KHM 157), which Bottigheimer considers to be "the most Christian" among the KHM tales (1987: 149), presents a prominent example of this practice. The story uses anthropomorphic animal characters to communicate biblical lessons about the importance of faith and humility. The lessons are reinforced on several narrative levels: the characters ${ }^{64}$ and the plot (the youngest sparrow who spends his days catching flies and spiders and listening to sermons enjoys God's protection), as well as an ideological and intertextual level. The story ends with an explicit, versed moral which advocates the virtue of faith, a clear conscience, and patient suffering.

The definition of legend has undergone considerable revisions in recent decades. Earlier research primarily focused on its reception and perception by the audience and storytellers, with belief in the narrative's veracity cited as the key genre-defining criterion (cf. Christiansen 1992). However, numerous scholars (most notably Linda Dégh) gradually brought the issue of belief into question, pointing to its subjectivity (it is unlikely that all members of a given narrating community believe the same story to be untrue or true), elusiveness (how is belief defined? whose belief is being considered?), and mutability (beliefs change over time; cf. Dégh 2001; Dégh \& Vázsonyi 1976[1971]; Oring 2008; Tangherlini 1994). Although the previous notion of legends as narratives that are believed to be true has largely been rejected, truth and belief remain integral to the genre. However, as Elliott Oring explains, it is the "negotiation", rather than imperative of truth, that is now understood to be the basis of the genre: "In a legend, the question of truth must be entertained, even if that truth is ultimately rejected" (1986: 125, original emphasis). In other words, although they may not be stories that demand belief, legends are nevertheless "stories about belief" (Ward 1991: 297, original emphasis). Furthermore, more recent approaches to legends propose definitions of the genre based on criteria other than belief or

64 The focus is on the youngest sparrow, who, by virtue of being both the youngest and weakest member of the family, and a sparrow - a species which the Bible often ranks among the least of God's creations - is the least among the least. 
veracity, such as form (mono-episodic narratives, elastic structure), language and style (verbal cues aimed at increasing the supposed believability of the narrative or at least suggesting that belief is expected; Klintberg 2010: 12-13; Tangherlini 1994: 8-11).

Legends are commonly divided into sacred (religious) and secular - a division linguistically supported, for instance, in German, which distinguishes between the religious Legende and the secular Sage (Klintberg 2010: 14), or Croatian, which uses the terms legenda and predaja (cf. Bošković-Stulli 1975[1968]), but is absent from English (among other languages), which relies on more descriptive terms to emphasise the difference. Intended to promote the values and moral principles of a given religious community (Bošković-Stulli 1963: 12), sacred legends include narratives about different figures from the religious imaginarium, such as saints ("Saint Solicitous", published only in the 1815 edition of the KHM) and apostles ("The Twelve Apostles", KHM 202, ATU 766), as well as the interaction between sacred and human characters. In the introduction to their collection of German legends, the Grimms (1816) provide a typology of secular legends, which encompass demonological (also known as mythological or supernatural), historical, local, and aetiological (origin, explanatory) legends. Since the aforementioned collection mostly consists of historical (centred on historical figures and events) and local legends (dedicated to notable individuals, events, or landscape relevant to the storytelling community), their absence from the KHM comes as no surprise. However, the KHM does contain various supernatural legends, most of which portray supernatural figures such as demons ("The Godfather", KHM 42, ATU 332, 334) or elves ("The Elves" (ii), KHM 39, ATU 476*), which are often dangerous and hostile to humans (Dégh 2001: 15).

The Grimms (and other researchers; cf. Dégh 2001) also cite aetiological (explanatory) legends, which provide explanations for the origin of life on earth, the universe and celestial bodies, entire plant or animal species, or some of their individual features (Dégh 2001: 51), such as the position of the flounder's eyes ("The Flounder", KHM 172, ATU 250A) or the sounds the various birds make ("The Wren”, KHM 171, ATU 221A, 221B), as a distinct sub-type of the genre. In view of their diversity and the large number of elements they borrow from other genres (animal/religious characters, Schwank elements, etc.), the initial classification for this research (Appendix 1) viewed them as a distinct genre category, rather than a sub-type of the legend. However, the consideration of narrative space as a possible genre criterion has led to a revision of our initial proposal, prompting a conclusion similar to that presented by scholars such as Elena Balzamo, who argue that aetiologies encompass generically diverse narratives which purport to shed light on the origins of various phenomena (2004: 93). The spatial organisation of tales with aetiological properties in our corpus supports this idea, as some of them feature only 
one domain (e.g. "The Wren", "The Flounder"), while others are dyadic (e.g. "The Hazel Branch", KHM 210). This suggests that the aetiological tale does not have a unique domain-based spatial structure and should therefore - from a purely spatial point of view - not be considered either as an autonomous genre or a sub-type of the dyadic (sacred, supernatural) legend. Rather, the aetiological impetus is organised around existing spatial structures (and other features) of other autonomous genres. Like the Schwank or didactic tale, the aetiology therefore appears to be a mode, rather than an independent genre.

Viewed from that perspective, "The Wren", "The Flounder", and "The Bittern and Hoopoe" (KHM 173, ATU 236*) may be characterised as aetiological animal tales, as they share the single animal domain of other animal tales in our corpus, while maintaining a unique thematic focus and temporal setting in the mystical "olden days" when "every sound still had its sense and meaning" ("The Wren"; Grimm 2003[1857]: 505), there was no order among fish ("The Flounder"), and the bittern and the hoopoe were cowherds instead of birds ("The Bittern and the Hoopoe"). While the transformations and name acquisitions in animal aetiologies are never the result of purposeful or deliberate action, but rather an accident, a byproduct of a given animal's actions, the remaining aetiologies in our corpus all feature all-powerful creators (various religious figures such as God, the devil, or the Virgin Mary) who intentionally create certain animal or plant species or alter their (physical) attributes. Considering their dyadic spatial organisation, identity of the main characters, and occasional didactic undercurrent, these narratives may be classified as religious (sacred) aetiological legends ("The Life Span", KHM 176, ATU 173; "The Twelve Apostles"; “The Blessed Virgin's Little Glass", KHM 207; "The Hazel Branch") and religious aetiological Schwank legends ("The Animals of the Lord and the Devil", KHM 148, ATU 773, 1184). In two tales in our corpus the animal tale "The Straw, the Coal, and the Bean" (KHM 18, ATU 295) and the religious Schwank legend “The Rejuvenated Little Old Man” (KHM 147, ATU 753) - the aetiological agenda is confined to the very end of narratives which in themselves are not aetiological, where it appears in the form of a coda (Röhrich 1991[1956]: 32-34).

Following the previously discussed reconsideration of the genre category of didactic tales, our initial corpus of KHM legends was expanded with the addition of exempla, brief mono-episodic narratives intended to teach lessons in morality by employing positive examples which are to be emulated or instilling fear through depictions of the often fatal consequences of improper behaviour (Zaradija Kiš 2012: 131). According to Antonija Zaradija Kiš (2012), exempla can be realistic or fantastic, a distinction supported by our own corpus, which contains one fantastic, dyadic exemplum, "The Ungrateful Son" (KHM 145, ATU 980D), which punishes the titular character who refuses to share food with his elderly father by having a 
toad permanently cling to his face, and one realistic, single-domain exemplum, "The Old Man and His Grandson" (KHM 78, ATU 980(1)). The former has been reclassified under legends in our corpus, the latter under folk tales.

Having provided preliminary definitions of the individual dyadic genres that are being analysed, the discussion proceeds to consider each of them alongside the fairy tale, using the previously identified features of the interdomain boundary as the basis for comparison: the fact that it can be crossed from both sides, the temporary nature of its crossing, and the special conditions on which it hinges. It should be noted that the comparison presented here is somewhat unbalanced, as the number of fairy tales in our corpus considerably exceeds that of representatives of other dyadic genres. The observations on religious tales and especially legends are based on a much more modest corpus, which may affect the conclusions presented here. Furthermore, the KHM contains only some sub-types of the legend (supernatural, sacred, aetiological), so the claims made about this genre do not necessarily apply to its other iterations (e.g. historical or local legends). However, despite its limited size, the corpus of non-fairy-tale dyadic KHM genres does allow for stimulating comparisons, which, while requiring further exploration on a more extensive body of work, nevertheless raise interesting questions and open novel avenues of thinking about the fairy tale and its relation to other short prose narrative genres.

\section{Crossing the boundary from both sides}

As this chapter has demonstrated, the interdomain boundary in fairy tales can be crossed from either side; in other words, non-magical characters can move into the magical domain and vice versa. Comparison of the fairy tale with other dyadic genres in the KHM suggests that, in and of itself, this fact is not unique to the fairy tale, as other genres also feature instances of the interdomain boundary being crossed from both sides. However, they either show a proclivity for the crossing of one side over the other, or the manifestations and conditions for the crossing differ depending on whether the human or the "otherworldly" is engaged in the transference.

The narrative world of the religious tale encompasses two clearly defined and firmly separated domains: the secular (human) and the sacred (cf. Eliade 1987[1957]), which corresponds to what Doležel terms the epistemic type of the mythological world (1998: 129). The two domains are also juxtaposed in terms of their materiality and representability, with the secular domain being concrete and material, and the sacred domain being spiritual and immaterial. Despite its prominence within religious narratives, the sacred domain is not explicitly described or directly featured (Jason 1971: 142). The majority of (the Grimms') religious tales end with the death of the protagonists, which signifies their admittance into the sacred domain. Some narratives explicitly refer to this transition: for instance, God 
pardons the hermit in "The Three Green Twigs", admitting him "into his flock once again" (Grimm 2003[1857]: 591); similarly, in "The Heavenly Wedding" (KHM 209, ATU 767), the protagonist goes "to the eternal wedding" - i.e. heaven - after receiving holy communion (ibid.: 594). However, the domain itself is not depicted nor does it become the setting for events. The only exception in the KHM is "The Peasant in Heaven" (KHM 167, ATU 802), which describes the different ways in which the rich man (music, singing, great joy) and the poor peasant are admitted to heaven. Expanding on Jesus's remark about the camel having an easier time passing through the eye of a needle than the rich man entering heaven, the story is less concerned with the afterlife and more with the exceptionality of a righteous rich man. In the majority of religious KHM tales, the sacred domain is presented only indirectly, through the appearance of sacred characters and references to the heavenly bliss that awaits the pious protagonists. Existing on an immaterial, spiritual plane, beyond the limits of human experience and cognition, the sacred domain is to an extent unrepresentable and as such lies beyond the boundaries of the narrative.

A similar division is characteristic of religious (aetiological) legends, which not only do not explicitly portray the sacred domain, but often fail to mention it altogether. The existence of the sacred domain in those narratives is therefore primarily implicitly construed, through references to its inhabitants. In religious aetiological legends such as "The Blessed Virgin's Little Glass", "The Twelve Apostles", "The Rejuvenated Little Old Man", or "The Ear of Corn" (KHM 194, ATU 779G*), religious figures such as God, St Peter, angels, Christ, and the Virgin Mary appear on earth, but their native domain is not mentioned. Even legends that are not explicitly set on earth but instead seem to suggest alternative dwellings for God and the devil, such as "The Animals of the Lord and the Devil" or "The Life Span", do not clearly identify or make direct references to these dwellings (it is unclear whether the titular Lord and devil reside in heaven and hell respectively, or whether God in "The Life Span" receives animals and man in heaven or on earth). The only exception is "Eve's Unequal Children" (KHM 180, ATU 758), which mentions Paradise as the home of Adam and Eve, from which they are banished at the beginning of the story.

In both religious tales and religious (aetiological) legends, inhabitants of the sacred domain can cross the interdomain boundary at will: religious figures such as the Lord ("The Poor Man and the Rich Man", "The Rejuvenated Little Old Man") or the Virgin Mary ("The Hazel Branch", "The Blessed Virgin's Little Glass") freely walk around the world, often rewarding the pious and punishing the undeserving. In religious tales, the sacred is also manifested as various supernatural occurrences which expose hidden truths (e.g. the bleeding bread in "God's Food", which reveals the rich sibling's transgression) or foreshadow future events (the sudden blooming of flowers announces death in "The Rose" [KHM 203] and "Poverty and Humility 
Lead to Heaven"). With the exception of "Eve's Unequal Children", which opens with an act of spatial transference from the sacred to the human on the part of human characters, religious aetiological legends featured in the KHM do not depict human characters crossing the interdomain boundary. The situation in religious tales is somewhat more complex since their thematic focus is often entirely on the said crossing. However, while they abundantly discuss and heavily imply it, as a rule they do not explicitly depict it.

In contrast to the free accessibility of the secular domain to religious characters, the immaterial sacred domain in the KHM religious tales is both physically and cognitively inaccessible to human characters, who can cross it only once and only if they meet up to special requirements (see below). Many religious tales offer fictional examples which clearly demonstrate what one should do or avoid in order to obtain the afterlife, i.e. permanently enter the sacred domain; in this way, crossing the interdomain boundary from the side of the secular becomes the central narrative drive. Their focus on obtaining happiness in the afterlife also sets religious tales apart from fairy tales, which focus on obtaining happiness in this life (Röhrich 1991[1956]: 35). However, since the said domain is, as previously stated, immaterial and, to an extent, unrepresentable, the transference itself is typically indicated through various metaphors. Perhaps most importantly, unlike in other genres under discussion, this act of transference is not a physical act of crossing boundaries, but a transformation and transition from one plane of existence (earthly, material) to another (spiritual). Thus, while the interdomain boundary in religious tales can, strictly speaking, be crossed from both sides, the transference from the human (material) into the spiritual (immaterial) domain takes on a form distinctly different from the transference of human characters in other genres under discussion.

The immateriality of the sacred domain and its inaccessibility to human characters is a common point of genre subversion in religious Schwank tales and religious Schwank legends, which invert the image of heaven (being the dominant manifestation of the sacred domain in the KHM tales) ${ }^{65}$ as a state of eternal bliss, an Edenic afterlife devoid of earthly problems, deprivations, and suffering (Walls 2002: 7-8; see also Brückner 1990). No longer a spiritual plane of existence, heaven in these narratives is portrayed as a physical location, which can be reached by climbing a very tall tree ("The Fleshing Flail From Heaven") or even walking for a long time. Thus, the dishonest protagonist in "The Tailor in Heaven" (KHM 35, ATU 800)

65 While Christian theology divides the sacred domain into heaven, hell, and Purgatory, religious KHM tales focus almost exclusively on heaven, which features both as a source of help and comfort, and the ultimate goal the characters wish to attain. On the other hand, hell - portrayed in a decidedly desacralised manner - is featured in religious Schwank tales, legends, and fairy tales (e.g. "The Devil With the Three Golden Hairs"). 
complains about the blisters on his feet he got from walking all the way to the gates of heaven. "Brother Lustig" even literalises the metaphor of the road to heaven or hell so that the happy-go-lucky protagonist reaches the black gates of hell by walking along a literal "wide and pleasant path" (Grimm 2003 [1857]: 275). The transference from the secular to the sacred which religious tales present as a transformative experience which includes the transference from one plane of existence to another, here becomes a physical journey undertaken by protagonists who are very much alive. Having completed the journey, they learn that heaven is a far cry from the care-free state of bliss they imagined it to be: rather, its inhabitants are engaged in all manner of strenuous activities, from threshing oats ("The Fleshing Flail From Heaven") to drawing water from a well and carrying beams ("Master Pfriem", KHM 178, ATU 801).

Like religious tales and legends, supernatural legends also allow supernatural characters to freely enter the human domain. They often do so in order to improve the lives of the human characters by, for instance, bringing gifts, like the toad in "Tales About Toads (ii)" (KHM 105, ATU 672B), or offering to help characters in need (God, the devil and death in "Godfather Death", KHM 44, ATU 332), or to harm them, for instance, by abducting children and leaving changelings in their place ("The Elves (iii)", KHM 39). Taking on the form of spirits or ghosts, the supernatural can also manifest itself in the human domain in order to reveal an injustice and secure punishment for it ("The Singing Bone", KHM 28, ATU 780; "The Stolen Pennies", KHM 154). The crossing of the interdomain boundary from the human side, while possible, is less frequent (at least in our corpus of KHM legends) and typically predicated on an invitation or pre-existing link with the supernatural (see below), while forced crossing is severely punished ("Mother Trudy").

\section{Temporary crossing}

While both non-magical and magical characters in the fairy tale may engage in spatial transference and interdomain crossing, they must return to their endemic domain by the end of the story. In other words, the crossing of the boundary between the domains is never permanent as individual characters cannot remain in a domain to which they do not belong. In contrast, other dyadic genres portray permanent acts of interboundary-crossing, especially on the part of human characters.

In religious tales, sacred characters are frequently found within the secular, human world, where they appear at will and for varying amounts of time. However, the same freedom is not accorded to human characters, who can enter the sacred domain only once. In other words, they can only engage in permanent crossing of the interdomain boundary. This permanence stems from the fact that admittance into the sacred domain (afterlife) requires human characters to die, thereby leaving their 
material, earthly existence behind and, in an irreversible process, to substitute it for a spiritual, immaterial one. While fairy tales also depict various types of (magical) transformations, they are generally temporary: if a young prince is turned into a frog, he will surely regain his human form - and, consequently, his place within the nonmagical domain - by the end of the story. Permanent changes to characters are found primarily on the level of their social status, as a humble peasant can be permanently "transformed" into a king. All other transformations, magical in nature, are temporary and reversible. In contrast, the interdomain crossing in religious tales is predicated on a permanent, irreversible change as it signifies a symbolic rather than physical transference which transports characters not between physical spaces but from one plane of existence to another.

Religious Schwank tales and legends subvert the notion that the admittance of human characters into the religious domain is permanent. Rather, (undeserving) characters can easily be thrown out of heaven or hell, or even completely obliterated from existence ("Gambling Hans", KHM 82, ATU 330). The tailor is escorted out of heaven and forced to stay at "Waitawhile, where the good soldiers sit and make merry" (Grimm 2003[1857]: 123) after he throws furniture at the people on earth ("The Tailor in Heaven"), while Gambling Hans is allowed to leave hell and enter heaven after he wins everything in hell with his deck of magic cards. Some characters even briefly visit heaven out of sheer curiosity ("The Fleshing Flail From Heaven") or in their dreams ("Master Pfriem").

As in religious tales, supernatural characters in legends can freely move across the interdomain boundary. This, however, is not the case with the human characters, who - in the case of the KHM - rarely move into the "otherworldly". In both cases, the transference may be either temporary ("The Elves (ii)") or permanent, as characters - both human and supernatural - can perish within the domain they are not native to. This happens to (among others) the toad in the first of three "Tales About Toads" (KHM 105, ATU 285, 285A) and the girl who is determined to meet the fabled witch in "Mother Trudy". Unlike fairy tales, in which death is usually reversible (with the exception of antagonists) as deceased characters can swiftly be brought back to life with the help of magical liquids or herbs, death in legends is always permanent and - unlike in religious tales - something to be feared and delayed for as long as possible. A number of KHM legends end with the death of the human protagonist ("Godfather Death"; "Tales About Toads (ii)"; "The Messengers of Death”, KHM 177, ATU 335); however, while religious tales, which often feature a similar ending, present it in a positive light, as a passage into a more blissful state of existence, legends lack such positive overtones. Even Schwank legends, which often portray characters outwitting death (e.g. "Godfather Death"), ultimately concede its inevitability. In fact, when the titular Gambling Hans tricks Death into climbing a pear tree from which she cannot come down, this has disastrous 
consequences for the whole world ("Gambling Hans"). While Hans continues to enjoy his time in the afterlife thanks to his magical deck of cards, he is ultimately thrown out of heaven, his soul smashing into pieces. Similarly, the stubborn child in the cautionary legend of the same name (KHM 117, ATU 760**) is punished for trying to return from the grave.

\section{Meeting special requirements}

Regardless of their non-magical or magical nature, fairy-tale characters must meet certain requirements in order to come into contact with the opposite domain. The conditions differ depending on the side from which the transference unfolds; thus, non-magical characters must pass a test set by the magical gatekeeper, earn magical assistance because of their vulnerable position, or be lured into the magical. On the other hand, magical characters can either forcefully enter the magical domain with malicious intentions or be summoned into it by non-magical characters. These requirements are of special importance for the fairy tale, which stands out as the only genre in our corpus in which special conditions exist for both sides of the boundary.

While it is not explicitly predicated on special conditions - probably because religious figures such as God or the Virgin Mary are all-powerful and therefore do not need permission to infiltrate the human domain - manifestations of the sacred within the secular in religious tales are often intended to provide assistance and/or guidance to human characters who are facing adversities or have strayed off the straight and narrow path. This is reminiscent of the vulnerability of fairy-tale human characters, whose misfortune may grant them admittance into the magical. Thus, negative or positive behaviour displayed by human characters may trigger the appearance of the sacred within the human domain, which then proceeds to warn, punish, counsel, or comfort the protagonist. For example, the anthropomorphic bird in "The Three Green Twigs" tells the hermit why he has fallen out of grace, while the spirits of the deceased appear to the old widow who blames God for the death of her family members ("The Little Old Lady") to comfort and explain to her that God had "taken [her sons] to himself as innocent children" so they would not grow up to be criminals, thus showing "her more kindness than she had been able to understand" (Grimm 2003[1857]: 593).

In contrast to the free accessibility of the secular domain to religious characters, the sacred domain is both physically and cognitively inaccessible to human characters, who can enter it only after they die, leaving their material, bodily, earthly existence behind. Furthermore, it is not automatically accessible to all who pass away, but only to those who have followed religious teachings, and led a just and pious life. As such, the adherence to religious teachings and demonstration of positive character traits such as generosity, modesty, and patience can be seen as a 
type of test of merit, which aims to determine who will be admitted into the sacred domain. Unlike their fairy-tale counterparts, who must perform the occasional act of kindness to prove they are worthy of magical assistance, for human characters in religious tales their entire earthly existence is an extended test of merit, one which can be failed at any moment (e.g. the hermit in "The Three Green Twigs" who passes judgement on a sinner being led to the gallows). The transference of human characters into the sacred therefore hinges on several conditions: their exemplary behaviour and adherence to church teachings during their lifetime, as well as their demise and subsequent transference from a material into a spiritual existence.

The conditions for admittance to the religious domain are another common point of subversion by religious Schwank tales and legends. While these narratives often feature a literal gatekeeper in the form of St Peter, he is typically portrayed as less than competent and is easily coaxed ("The Tailor in Heaven") or tricked ("Brother Lustig") into admitting undeserving characters into the celestial domain. Rather than the exclusive abode of the righteous, heaven thus becomes the home for the thieving tailor who proceeds to pass judgement on others who commit the same crime ("The Tailor in Heaven"), the dishonest soldier who tricks his way into the celestial domain ("Brother Lustig"), and a compulsive gambler who leads a host of hunchbacked devils in an attack on heaven ("Gambling Hans"). Since they subvert the notion of heaven as an idyllic spiritual realm, religious Schwank tales and legends often dismiss the notion that human characters can be admitted there only after they die. Thus, Brother Lustig decides it is time for him to enter the kingdom of heaven simply because he has grown tired of wandering the earth, while the (living) farmer in "The Fleshing Flail From Heaven" pays a short visit to heaven because a giant plant has sprung in front of his house.

As previously noted, the KHM legends are predominantly focused on the appearance of the supernatural within the human world and rarely depict the movement of human characters into the supernatural domain. When this movement does occur, it is - as with fairy tales - usually dependent on a pre-existing connection with the target domain and the meeting of certain requirements for entry. For instance, the familiar relationship between the human protagonist and the supernatural character may be interpreted as some sort of invitation or permission for the former to enter the house of the latter. In the second of "The Elves" tales, a servant girl receives an explicit invitation from the supernatural to stand as godmother at an elven christening. As in fairy tales, the supernatural seeks contact with the human world because it requires its assistance. The invitation is followed by the appearance of three elves, who lead the girl into the supernatural domain, located within a hollow mountain. The supernatural - in this case, Faerie - domain is close to the human world, but clearly separated and concealed from it, with various landscape items in the human world such as cave entrances serving as passages into 
the (underground) Faerie realm. In the most notable departure from the fairy-tale model, time within the supernatural domain often passes at a different pace from in the human domain - especially in legends about the various types of fairy folk (Briggs 1978: 11-26). Thus, upon her return home, the servant girl learns that during the three days she spent with the elves, seven years have passed in the human domain. In contrast, time and its passage in the fairy tale have seemingly no effect on the characters. Vast expanses of time are frequently mentioned, but do not seem to alter the characters, who apparently do not age. The hundred-year period in "Brier Rose" passes by in an instant, leaving those affected by the curse utterly unchanged (in fact, they all go back to their errands, as if nothing at all had happened; cf. Lüthi 1970[1962]: 37-38). Crossing the interdomain boundary without such a pre-existing connection often ends badly for the human character (the girl in "Mother Trudy" is turned into a $\log$ and thrown on the fire).

\section{Space as the basis for genre definitions and classifications}

While the existence of two domains is not exclusive to the fairy-tale genre, this thesis argues that the concrete ways in which the interaction between the non-magical and the magical, and the crossing of the interdomain boundary are negotiated and realised are. The fairy tale is set apart from other dyadic tales in our corpus is several distinct ways: first, the interdomain boundary between the magical and non-magical in fairy tales can be crossed from either side, while other dyadic genres predominantly focus on the transference of supernatural characters into the human domain. Second, the crossing of the interdomain boundary in fairy tales is always temporary, with characters returning to their endemic domains by the end of the story. In contrast, boundary-crossing on the part of human characters in religious tales and legends is often permanent, as they must die in order to engage in the transference (religious tales) or die as a result of it (warning legends). Third, the crossing of the interdomain boundary in fairy tales is predicated on very specific conditions that both nonmagical and magical characters have to meet if they are to move into the domain they are not endemic to. This is not true of other dyadic genres included in the present analysis, which typically create conditions only for human characters (e.g. human characters in religious tales must be pious and good in order to enter heaven), while their supernatural/sacred counterparts are able to cross the interdomain boundary at will.

Based on these findings, the preliminary, working definition of the fairy tale presented in the Introduction to this thesis can be modified to include the spatial dimension. The fairy tale might, therefore, be defined as a (short) prose narrative which features two domains, the non-magical and the magical, which, although clearly delineated and separated, must come into contact in the course of the story, 
as the protagonist's success typically hinges on magical assistance. The interaction between the domains is dependent on spatial transference, most notably the crossing of the interdomain boundary, which can be temporarily crossed from both sides, but only if specific conditions are met.

In addition to expanding our understanding of the fairy-tale genre, the consideration of spatial issues has also led to a re-examination of other genres identified in our initial research corpus (Appendix 1). Most significantly, it has brought into question the status of didactic tales, aetiological tales, and Schwank tales as autonomous genres. Thus, the study of the narratives initially placed in these three categories from the point of view of space - specifically, domains - has revealed that they do not share a common underlying spatial structure. Rather, some narratives within the individual categories feature only one domain ("realistic" or "otherworldly"), others two. This points to the conclusion that rather than having a unique spatial structure of their own, the three presumed genres "borrow" the domain-based models of other genres. This, in turn, suggests that, from a purely spatial point of view, didactic tales, aetiological tales, and Schwank tales should not be viewed as autonomous genres but as modes that can be attached to other genres, such as animal tales (aetiological animal tale, cautionary animal tale), religious tales (religious Schwank), or fairy tales (Schwank fairy tale, warning fairy tale). The fact that all three modes are defined through their function (to educate, entertain, and explain) also suggests that function may not be manifested on the spatial level or demand a unique spatial framework. This is a stimulating topic for future research which might examine more closely the relationship between space and other common genre criteria, such as structure, theme, or audience.

As a result of these findings, the initial genre classification of our corpus has been revised, with narratives originally categorised as didactic, Schwank, or aetiological tales now re-classified as sub-types of fairy tales, animal tales, folk tales, formula tales, legends, or religious tales (see Appendix 2). The expansion of the remaining categories (especially the fairy tale) with new sub-types has further highlighted their spatial profiles. This is especially evident in the case of the different Schwank sub-types, which acknowledge the importance, for instance, of boundarycrossing and its conditions for the genre by subverting its traditional manifestations (e.g. the test of merit).

It should be noted that the observations presented here are based on a somewhat generically unbalanced corpus. Thus, since the corpus of this research primarily consists of fairy tales, the explorations of other genres are based on considerably more limited corpora - both in quantitative and qualitative terms (the analysis includes only some types of legends). Future research should therefore focus on larger corpora of animal tales, legends, religious tales, and other short prose narrative genres, and explore not only the way they negotiate interdomain and other 
boundaries, but also the specifics of the structure, representation, qualities, and functions of their narrative spaces.

Another important consideration to bear in mind is that, despite its revisions, our corpus still contains narratives which might be labelled as "problematic" or "hybrid", as they not only combine the content features of different genres, but also their spatial structures. The most notable example is "The Singing Bone", identified in Appendix 2 as a fairy-tale religious legend. The first part of the story follows a familiar fairytale pattern complete with a difficult task (slaying a wild boar), competing for the hand of a princess, a magic donor/helper (the dwarf who gives the hero a black spear), and two brothers: one good and pure of heart (the hero), the other jealous and cunning (the false hero or villain). Although the story does not explicitly describe a test of merit, the hero is granted magical assistance as a reward for his positive traits: "I'm giving you this spear because you have a good and pure heart" (Grimm 2003 [1857]: 99). However, once the difficult task has been completed, the tone of the story becomes much darker as the jealous brother murders his sibling and presents himself as the hero. Even at this point in the story we are not completely in the realm of legend as the motif of the murderous false hero who misrepresents himself as a monster slayer is common in fairy tales (the Grimms themselves use it, for instance in "The Two Brothers"). What signifies a departure from the fairy-tale genre is the fact that the death of the protagonist is permanent; in contrast, the murdered protagonist in the aforementioned "Two Brothers" is brought back to life with the help of a magic herb and later exposes the false hero as a liar and murderer. The villain in "The Singing Bone" is exposed as well, but the revelation of his crimes comes from beyond the grave and serves to impart the lesson that justice is slow but sure, because "nothing remains hidden from God" (ibid.: 100). The motif of the telltale bone may be associated with the popular belief that the human soul lingers on in individual parts of a person's body such as hair, bones or blood (Uther 2013[2008]: 74), while the revelation in the form of a song and its associations with nature are reminiscent of the legend of King Trojan/Trajan (cf. Bošković-Stulli 1967). However, the existence of a soul points to the afterlife as a distinct supernatural domain in the story. Thus, the story blends the two genres and their spatial patterns in such a way that they share the human domain but retain their specific non-realistic domains: the magical (embodied in the magical helper) and the supernatural (the soul, God, afterlife), thus creating what might be termed a hybrid (triple-domain?) spatial structure. This and similar cases demonstrate that, like any classification criteria, space by no means provides the definitive word on genre, as no genre category (no matter what it is based on) can perfectly describe every single one of its members (cf. Lüthi 1986[1947]: 108).

Despite the somewhat generically unbalanced nature of its corpus, the research presented in this and the previous chapter suggests that space-based genre 
classification can (and should) go beyond the simple identity of space, i.e. the notion that, as Moretti (1998[1997]) claims, each genre requires a specific space, so that, for instance, science fiction stories unfold on strange planets or in distant galaxies, while Robinsonades require deserted islands. Rather, this research argues that the identification and organisation of individual spatial units, as well as their interaction, can provide the basis for a more comprehensive understanding of individual genres and differentiating between them. Investigations of space, which can be seen as part of a given genre's unique profile, offer a lot of potential for studying genres ${ }^{66}$ by opening new avenues of thinking about their specific features.

66 Some scholars have already recognised this potential. Daniel Sävborg (2018), for instance, ascribes the fact that supernatural occurrences in the Icelandic sagas sometimes cause fear or surprise, but are calmly accepted at other times, to different settings. Thus, when manifestations of the supernatural are encountered in Iceland (i.e. when they are in the vicinity of the narrator/author), they provoke shock or disbelief, while those experienced in foreign lands are accepted as something strange, but not belonging to a different dimension. 


\section{$5 \quad$ Presenting Space}

Having discussed the structure of narrative space in the fairy tale and what that can tell us about the genre, this thesis now focuses on the types and extent of spatial information provided by fairy tales, as well as the means of conveying it. More specifically, the present chapter proposes to examine the (narrative, linguistic) strategies the KHM fairy tales use to establish individual spaces, their qualities, dimensions, and inter-relationships by utilising narratological textual analysis (Bal 2017[1985]; Dennerlein 2009; Ryan 2014[2009]; Ryan et al. 2016). This type of research has largely been absent from fairy-tale studies (for exceptions, see Messerli 2003 , 2005), where the general consensus seems to be that fairy tales are not overly concerned with space and therefore provide very little spatial information. The lack of interest in space is typically ascribed to the genre's focus on action, which necessitates a sparse narrative style that omits anything that does not directly help move the plot forwards, especially descriptions (Lüthi 1986[1947]: 24, 92). Such a view is reminiscent of the long-held understanding of narration and description as juxtaposed and mutually exclusive, which sees description as a pause, even a retardation of narration, and therefore less important (see, for instance, Ronen 1997).

In its attempt to challenge the validity of claims regarding the (traditional) fairy tale's lack of interest in space and subsequent dearth of space-related information, the present chapter takes as its starting point the notion that even narratives that withhold explicit spatial information (as fairy tales seem to do) inevitably "imply a world with spatial extension" (Ryan 2014[2009]: 796). Thus, even a minimal plot such as E. M. Forster's famous example "The king died, and then the queen died of grief" (1985[1927]: 86) does not take place in a vacuum, but presupposes the existence of some kind of physical environment for the tragic events (in this case, a royal castle). The present research therefore argues that the lack of explicit spatial reference in fairy tales should not be seen as a sign of the genre's disregard or disinterest in space, or the irrelevance of space for the fairy-tale narrative; rather, the genre's focus on action and economical style demand that spatial information be expressed in different, less direct ways. Furthermore, as Zoran notes, "only a small part" of narrative space is presented through direct description (1984: 313), meaning that even description-heavy texts can never depict every single aspect of narrative 
space, leaving instead c(l)ues for readers to fill in the missing information for themselves (see Chapter 3). Employing textual analysis, this chapter examines both explicit spatial references and the various c(l)ues provided by the KHM fairy tales in more detail.

Building on the narratological research of Bal (2017[1985]), Dennerlein (2009), and Ryan (2014[2009]; Ryan et al. 2016), as well as the classification of descriptions proposed by Ansgar Nünning (2007), the present chapter distinguishes between direct (explicit) or independent, and indirect (implicit) or dependent strategies for conveying spatial information. Direct strategies, which make explicit references to space, include naming and (direct) description. Indirect strategies rely on references to objects, characters, and their actions (especially movement) to establish the identity of a given space and/or its dominant quality (cf. Dennerlein 2009: 96-98). Although the following sections discuss each of these strategies separately, it is important to note that individual strategies often overlap (any instance of conveying spatial information is to some extent descriptive). The final section of the chapter focuses on the strategies fairy tales use to establish spatial dimensions and relationships between individual spaces.

\section{Naming}

The basic direct strategy for establishing a narrative element - in this case, narrative space - is its explicit identification through naming. Naming -i.e. identifying a given space as, for example, a house, a forest, or a mountain - aims to bring the existence of a given element to the readers' attention, "to conjure a presence in the mind" without designating its specific properties (Ryan 1991: 128). As such, it might be anticipated as a common strategy in fairy tales which, as already noted, eschew any type of "additional" information, focusing instead on the very basic. Lüthi suggests as much by stating that fairy-tale spaces are "always simply named, never described" (1986[1947]: 25).

The KHM fairy tales rarely use proper nouns (toponyms) to identify spaces (see Chapter 6). Rather, the genre's abstract style (Lüthi 1986[1947]: 50, 104) demonstrates a proclivity towards common, concrete nouns, such as forest, village, kingdom, or house, preceded by indefinite or definite articles (cf. Robinson 2010: 87). Although such a lack of specificity results in "a low degree of individualization" (Nünning 2007: 107), creating the impression that the story could take place anywhere (see Chapter 6), Ryan points out that even the most generic of nouns can convey meaning through "the richness of their connotations", providing "descriptive shortcuts" that invoke "ready-made pictures" in the minds of readers (1991: 128).

However, as the sections on indirect strategies will demonstrate, individual fairytale spaces are not always explicitly named; rather, their identity and traits may be 
implied through references to their inhabitants or the objects they contain. Generally speaking, the identity of the initial, non-magical domestic space is most likely to be inferred through reference to its inhabitants, rather than being explicitly named. In cases when it is directly identified, it plays an important role in the story. For example, "The Poor Miller's Apprentice and the Cat" begins by introducing us seemingly redundantly - to "a miller who lived in a mill" (Grimm 2003 [1857]: 351). While the type of space could easily be deduced from the identity of its owner, the mill itself plays an important role in the story as the prize the apprentices are competing for, which is probably why it is explicitly mentioned. The identity of the home of the miller in "The Nixie in the Pond" is similarly highlighted because of its role in the plot: specifically, the beginning of the story marks a sudden decline in the miller's fortunes as his wealth begins "to decrease each year until the miller could hardly call the mill that he inhabited his own" (ibid.: 527). The beginning of "The Fisherman and His Wife" establishes that the titular characters live "in a dirty hovel near the sea" (ibid.: 65), a source of much of the wife's dissatisfaction, which propels the plot. With the exception of castles or palaces, spaces within the magical domain are more frequently named (and even described; see below) than their non-magical counterparts, perhaps because they are not part of the world of the protagonist (and, by extension, the reader) and therefore need to be established more clearly.

In some cases, only parts of a given space are explicitly named, their presence indicating the larger space which remains unnamed. Following the pars pro toto principle, the highlighted object thus becomes a synecdoche - defined here as "a relation in which a part stands for a whole or a whole stands for a part" (Seto 1999: 92) - for the larger space to which it belongs. For instance, if the narrative states that someone is knocking on the door, readers recognise that this is not a self-standing door but part of some sort of building (a house or a cottage, perhaps) without being explicitly told this. In such a scenario, the door becomes a stand-in for the entire space of the house (Messerli 2005: 276). This is the case in (among other tales) "The Three Feathers", which never explicitly names the underground dwelling of the enchanted frog. Rather, the protagonist lifts a trapdoor, goes down the stairs and comes to another door. He returns there on two occasions, but each time the narrative avoids naming the abode, stating instead that he went "to the fat toad" (Grimm 2003[1857]: 234). In "The Drummer", the narrative does not mention that the protagonist returns home after stumbling upon some white linen on a lake shore. Rather, after he puts the cloth in his pocket, we find him sleeping in his bed. The text does not explicitly identify the drummer's dwelling, relying on readers to infer its existence through references to the furniture and the protagonist's activities.

Like the named locations themselves, these singled out or "focused-upon" elements are made significant already through the act of singling out (Herman 2002: 275) and are typically mentioned because they are important to the plot. Frequently 
highlighted spatial elements include doors and windows, probably because of their role as passages between the outside and inside (cf. Messerli 2003: 362). Windows in particular allow the inviting light inside the house to be seen for miles around and offer characters standing outside, such as the prince in "Spindle, Shuttle, and Needle", or the count, king, and queen in "The Goose Girl at the Spring", a glimpse of the interior. In addition to naming its individual parts to identify a larger space which remains unnamed, the fairy tale can also name parts of spaces which have been explicitly identified, such as "the door to the forbidden room, the window high above in Rapunzel's tower, or the castle stairs upon which Cinderella loses her [...] shoe" (Lüthi 1987[1975]: 41). While not essential for establishing the identity of space, such highlighted elements help make it more concrete.

\section{Description}

Often cited as "the major discourse strategy for the disclosure of spatial information" (Ryan 2014[2009]: 802), description - or, more specifically, direct description serves to identify "the properties of place, objects, or persons" (Pflugmacher 2005: 101). As such, it helps make the narrative world more "visible and concrete", while also establishing tone or mood, conveying relevant information, and contributing to characterisation and theme reinforcement (Bal 2017[1985]: 26). Within narratological research, description was traditionally viewed in opposition to narration, as a pause in and temporary suspension of narration, and even "a refusal to narrate" (Herman 2009: 90). As such, it was dismissed as subordinate to narration, a sentiment perhaps most famously expressed by Genette, who calls description "ancilla narratienis [the handmaiden of narration], the slave always necessary, always submissive, never emancipated" (1976[1969]: 6).

The view of narration and description as mutually exclusive is mirrored in the discourse on the fairy tale, which has, given its focus on action, been described as virtually incompatible with descriptions. Lüthi's claim that "the compulsion to describe is alien to [the fairy tale]" (1987[1975]: 20), which consistently avoids "any sort of stilus ornatus" (ibid.: 110), is echoed by Beth Franks, who observes that "[f]airy tales tend to be long on action and short on description" (2001: 249). In a similar vein, Nünning identifies a continuum of descriptions based on length and frequency that stretches between two extremes: the nouveau roman, which strives to exclude plot in favour of descriptions, and the fairy tale, which eschews descriptions (2007: 107). The present research brings these claims into question by suggesting that, even though the fairy tale (at least in its traditional form) is by no means description-heavy, its focus on action does not entirely come at the expense of descriptions. Rather than exclude them altogether, the said focus on action determines their type and extent. 
The KHM narratives often rely on brief, selective descriptions to highlight "one or just a few significant details" (Nünning 2007: 100) about a given space, usually in the form of various premodifiers (adjectives, adverbs, pronouns, quantifiers, etc.) and postmodifiers (prepositional phrases, non-finite and dependent clauses). In most cases, the premodifier consists of one or two adjectives ${ }^{67}$ (preceded by an article), or possessive pronoun and adjective, which emphasise select aspects and/or qualities of a given space, such as: "an old tower" (Grimm 2003[1857]: 172), "a great, dense forest" (ibid.: 248), "his royal castle" (ibid.: 362), "my lonely hut" (ibid.: 529), or "an old stone house" (ibid.: 560). The very act of mentioning a particular quality lends it significance, presenting it as "preeminetly representative and impl[ying] that it sums up the essentials of the object described" (Riffaterre 1981: 111). As Franks points out, these select, brief descriptors carry greater weight in a genre as economical as the fairy tale than they might "in a more adjective-rich narrative" (2001: 250). In other words, since the fairy tale does not abound in descriptors, their appearance in the text suggests they must be important for the plot. For example, a forest described as "dark" is most likely the home of a malicious figure, such as a wife-murdering wizard ("Fitcher's Bird") or an intimidating giant ("The Giant and the Tailor"), while a "large" or "huge" forest is one in which the main character is bound to get lost. Lüthi makes a similar observation when he points out that the fairy tale will explicitly identify only those attributes that play a role in the story; a forest can therefore be described as large or dark, but not as green (1976[1969]b: 28). In cases when more than one descriptor is attached to the noun, each of them reveals information relevant for the plot. In "The Spirit in the Glass Bottle", for example, the protagonist comes across "a huge dangerous-looking oak" which "must have been hundreds of years old at the very least, and it would have taken more than five men to span it" (Grimm 2003[1857]: 335). All the attributes of the tree that are mentioned - its size, age, and ominous look - anticipate the nature of the spirit trapped in the bottle that is hidden among the roots. Like the oak, this "horrible fellow" is large ("half as big as the tree") and - judging by the "long time" he spent in the bottle - very old, as well as dangerous and malicious (he threatens to break his saviour's neck; ibid.).

The adjectives accompanying space-signifying nouns featured in the KHM are used to specify the various physical properties of space, such as its size (large, small, deep, high), colour (grey, green), or material (a stone house), as well as age (old, new), possession, and various subjective qualities (beautiful, wild, enchanted, dangerous, etc.). While not exclusive to particular spaces, certain adjectives appear mountain). 
more frequently with some spaces than with others. For example, the KHM forest (Wald) is commonly described as large/big (groß), dark (finster, dunkel), wild (wild), or deep (tief), while the castle or palace (Schloß/Palast) is usually royal (königlich), beautiful (schön), splendid (prächtig), or enchanted (verwünscht). ${ }^{68}$

Descriptive postmodifiers in the Grimms' fairy tales include various prepositional phrases and relative clauses which add new or reinforce existing information about the space-signifying noun that precedes them. They serve to establish (among other things) the location of the space ("his house in the middle of the dark forest"; Grimm 2003[1857]: 155), its size ("the castle, which was larger than the castle of the king's daughter"; ibid.: 418), physical appearance ("a city that was completely draped in black crepe"; ibid.: 216), or other qualities ("a castle that was enchanted", ibid.: 397; "the glass mountain, which was very slick", ibid.: 417), as well as the spatial items it contains ("a large heath, where nothing but a circle of trees could be seen", ibid.: 340). Postmodifiers may also elaborate on and/or intensify the meaning expressed by the premodifier adjective: for example, "a huge forest that was impossible to cross in one day" (ibid.: 214), or "a secret and solitary chamber where no one else ever went" (ibid.: 186). In some cases, prepositional phrases and relative clauses are combined into longer, more information-heavy postmodifiers, as in: "a high mountain at the edge of the forest, where the fox and the hare say good night to each other" (ibid.: 195) or "the mountain, which seemed as though it were as high as three mountains stacked one on top of another, and it also seemed as slick as glass" (ibid.: 559). Once again, the information revealed is relevant to the plot. In the first example from the previous sentence, which appears in "Rumpelstiltskin", the messenger is telling the young queen where he discovered the titular character. The distance and marginal position of Rumpelstiltskin's abode are explicated not only to suggest its magical quality but also to highlight its inaccessibility and seclusion from the human domain. This is especially important since the messenger had previously searched "high and low" throughout the country as well as the neighbouring area, collecting unusual names for the queen (ibid.: 195). Since these familiar, human spaces could not provide a solution to the queen's problem, he turned to unknown areas. The second example (from "The Drummer"), which refers to the very tall glass mountain, emphasises those attributes of space that might use Orrin Robinson's [2010] study of gender-related language as a productive model for future explorations of space-related language in the KHM tales) - perhaps complemented by digital tools, which allow researchers to easily navigate large corpora (see, for example, Jorgensen 2014, 2019; Ragan 2009; Weingart \& Jorgensen 2013) of both the German originals and the English translations would certainly further promote our understanding of the representation of narrative space and means of conveying spatial information in (the Grimms') fairy tales. 
reveal its magical quality (three times larger than "ordinary" mountains and made of glass) and suggests that the protagonist will not be able to climb it without magical assistance (a magic saddle).

Just as not all fairy-tale spaces are explicitly named, not all of them are described. As with naming, the presence and extent of spatial descriptions vary depending on the individual space, its role in the story, and position within the fairy-tale domains. Generally speaking, magical spaces tend to be described more frequently and in more detail than non-magical ones. In "The Worn-out Dancing Shoes", for instance, the non-magical is not even explicitly identified (the soldier simply presents himself before the king), while its magical counterpart is described as "beautiful" and "brightly lit", situated on the lake shore and filled with "merry music" (Grimm 2003[1857]: 434). Once again, the narrative relies on readers to draw on their realworld experience and knowledge to identify and mentally construe non-magical spaces, which therefore do not necessarily require a lot of detailed information; in contrast, magical spaces present a new experience for both the protagonist and the reader, and therefore need to be more clearly established.

Despite the prevalence of succinct descriptors in the KHM fairy tales, lengthier, block descriptions are not entirely absent from the collection. In most cases, they are used to establish luxurious, especially regal environments, often conjured up by magic. This is the case in "The Fisherman and His Wife", a story of a disgruntled woman who constantly wishes for more wealth and power. Her movement up the social ladder, from poor fisherman's wife to the pope, is depicted as a series of transformations of her impoverished living quarters into increasingly affluent environments. The growing material wealth and physical size of each new location are mirrored by the descriptions, which also grow in length and amount of detail. While the impoverished initial location is briefly described as a dirty and "disgusting" hovel (Grimm 2003[1857]: 67), the little cottage, castle, palace, and church into which it is subsequently transformed are all described in more detail, which highlights how far up in the world the wife has come. The descriptions of these new dwellings list their surroundings (yard with animals, a pleasure garden) and numerous rooms covered in tapestries and carpets, revealing them to be (at least partially) made of precious materials such as marble and alabaster, filled with tables laden with food, as well as furniture and other items made of gold, crystal, velvet, and even diamonds. The focus on luxury and material wealth reveals not only the power of the wish-granting flounder, but also the height (and foolishness) of the woman's ambition and dissatisfaction: even though she seems to have everything she could possibly want (especially compared to the dreary environment she used to live in), she continues to crave for more.

The KHM fairy tales dedicate the most attention to royal spaces - both magical and non-magical - highlighting their extraordinariness and luxury by mentioning a variety of details. Compared to "ordinary", non-magical houses and cottages, royal 
spaces are typically filled with more objects (furniture, decorative items, etc.) made of rare and precious materials: the floors ("The Two Travelers", KHM 107, ATU 613) and steps ("The Frog King") are made of marble, and the splendid tables ("Hans My Hedgehog") are always "covered with delicious food" (Grimm 2003[1857]: 255). Descriptions of castles - especially those created by magic or through the transformation of humble dwellings - are among the lengthiest in the Grimms' fairy tales and closest to scene-setting block descriptions. In the following passage from "The House in the Forest", the heroine, who falls asleep in a poor forest cottage, wakes up in a decidedly different environment (ibid.: 503):

She was lying in a huge hall, and everything glistened around her in royal splendour. Golden flowers grew on a background of green silk high on the walls. The bed was made of ivory and the covers of red velvet, and there were a pair of slippers on a nearby stool that were embroidered with pearls. The maiden thought it was a dream, but three richly dressed servants entered and asked her what her orders for the day were.

The image of wealth and splendour is evoked through references to precious materials (gold, silk, ivory, velvet) and richly decorated items (pearl-embroidered slippers, velvet covers, etc.).

The most comprehensive description of both a royal and magical space in the Grimms' collection is found in "The True Bride". When the evil stepmother demands that the heroine build her a castle in a single day, a helpful old woman uses her magic powers to satisfy the impossible demand. The narrative dedicates a lot of attention to describing the castle, from the process of its creation to the splendid final result (Grimm 2003[1857]: 539-540):

[T]he walls of the rooms were covered with silk and velvet. Brightly colored embroidered chairs stood next to richly ornamented armchairs at marble tables. Crystal chandeliers hung from the ceilings and cast their reflections on the polished floor. Green parrots sat in golden cages, and there were exotic birds singing lovely songs. The entire castle was filled with splendor, as though a king were going to move in.

As in the previous example, the extraordinary splendour and magical quality of the castle are highlighted through references to precious metals and ornaments, such as silk, velvet, marble, and crystal, as well as rare exotic birds. As it unfolds, the story reveals new information about this "splendid" (prächtige Schloß; ibid.: 540) and "magic" (Wunderschloß; ibid.: 542) castle, especially during the stepmother's inspection, when the dazzlingly bright interior is explored, complete with a fully 
equipped kitchen, steps covered with red carpets, and a golden landing decked with blossoming trees. After the heroine moves in, she discovers even more wonders, including drawers and closets filled with pearls and jewels, as well as splendid star-, moon-, and sun-embroidered dresses.

The considerable attention dedicated to royal spaces in fairy tales and insistence on their luxury might be explained with Röhrich's argument regarding the perspective of the storytellers, which he maintains that the world of the fairy tale is constructed from the point of view of the lower classes, whose "conception of monarchy is associated above all with a life of abundance and beautiful clothes" (2008[2002]: 138). This is the perspective of people who do not live in (and possibly never even set foot in) a castle but ascribe everything royal the highest of values. Thus, when fairy-tale narratives want to establish that something is of extraordinary value, they describe it as being fit for royalty; for example, the castle in "The True Bride" is so splendid "as though a king were going to move in" (Grimm 2003[1857]: 540), while the one in "The Drummer" is surrounded by "gardens, woods, and meadows fit for a prince" (ibid.: 563). Viewed from this perspective, the king always wears a golden crown, even when he is out hunting ("Brother and Sister"), and everything in his home is made of gold (Röhrich 2008[2002]: 130). In her analysis of the fairy-tale castle motif, Sabine Wienker-Piepho makes a similar observation, stating that the rich and luxurious castle presents a stark contrast to the presumably poor dwellings of the storytellers, and is therefore typically described in more detail (2019: 7).

Although they are mostly reserved for royal spaces, descriptive segments can also be used to set up less luxurious, natural settings, such as the surroundings of the wise woman's cottage in "The Goose Girl at the Spring". When the young count who carried the woman to her cottage looks around, he discovers "a green meadow covered with cowslips, wild thyme, and a thousand other flowers. There was a clear brook that glistened with the sun's rays and rippled through the middle of the meadow. The white geese waddled back and forth or paddled in the water" (Grimm 2003[1857]: 521). Similarly, "The Drummer" devotes some attention to the top of the glass mountain (ibid.: 560):

On top of the mountain was some level ground on which an old stone house stood. In front of the house was a large fishpond and behind it a dark forest. No human beings or animals could be seen. Everything was quiet. Only the wind rustled through the trees, and the clouds flew by close to the drummer's head.

Regardless of their length, direct descriptions in the KHM are primarily functional rather than ornamental, meaning that the narrative is less concerned with providing a detailed representation of the fictional world of the story and more in the story itself (cf. Nünning 2007: 114). As a result, it provides information about the different 
aspects of individual spaces when these are relevant for the plot. The highlighted adjectives and (less frequently) descriptive passages therefore serve to establish the key traits of a particular space (e.g. whether it is safe or threatening, magical or nonmagical) and its role in the story.

It bears repeating that the observations about direct descriptions in fairy tales presented here are corpus-specific and as such do not necessarily apply to other types of fairy tales. In fact, the findings presented by other scholars working with different corpora point to the existence of a description-based spectrum, ranging from the oral fairy tale, which is characterised by minimal descriptions (Lüthi 1987[1975]: 15), to the literary fairy tale, such as the tales of Giambattista Basile, whose lavish, baroque descriptions are characterised by "a hypertrophic abundance of detail" (Canepa 1999: 207). Furthermore, given the extent of the Grimms' editorial interventions, which also include stylistic and other verbal alterations (e.g. replacing indirect with direct speech, adding diminutives and proverbs, etc.; see, among others, Bottigheimer 1987; Robinson 2010), and the fact that they often developed and expanded the early versions of their tales ("Hansel and Gretel", for example, more than doubled in length from 1812 to 1857), it might be assumed that the descriptions in the fairy tales (or at least the lengthier ones) are their own, later additions to the collection. However, this assumption requires a more comprehensive, linguistic analysis of our corpus, as well as detailed comparisons between the different editions of the same tales, which lies beyond the scope of the present research.

\section{Descriptised narration, narratised description}

Numerous researchers have challenged the previously mentioned long-held view of description and narration as mutually exclusive, arguing that the same text can have both a descriptive and narrative function, since description also takes place "in and through the forwarding of the action itself" (Sternberg 1981: 73; see also Ronen 1997). In other words, action is not suspended to make way for description; rather, the two can become intertwined as the text simultaneously describes and narrates, resulting in what Harold F. Mosher terms descriptised narration and narratised description (1991: 426). The former functions as a kind of description "disguised as a narration", meaning that a passage which appears to be narrative reveals an underlying descriptive function, while the latter "disguises a narration as a description" (ibid.: 427). ${ }^{69}$ Arguing for the dynamic nature of space (or, to use his

69 Meir Sternberg identifies a similar continuum of narration and description situated between two extremes: "pseudo-description, where the sequence of spatial representation turns into a sequence of spatial clues and anchors for a developing action, and pure description (pseudo-action included)" (1981: 76). 
terminology, landscape) in the fairy tale, Likhachev claims that the genre does not contain "static descriptions"; rather, all description unfolds through movement and serves to develop the action (2014[1967]: 223).

Unlike direct description, which foregrounds space, descriptised narration primarily focuses on events (action), with space remaining in the background; however, while disclosing events, it also provides information about the environment in which unfold. Consider the following example from "Brier Rose", which, while explaining how the entire castle falls into a magic slumber, also reveals numerous details about the space of the castle and its surrounding (Grimm 2003[1857]: 172173):

This sleep soon spread throughout the entire palace. The king and queen had just returned home, and when they entered the hall, they fell asleep, as did all the people of their court. They were followed by the horses in the stable, the dogs in the courtyard, the pigeons on the roof, and the flies on the wall. Even the fire flickering in the hearth became quiet and fell asleep. The roast stopped sizzling, and the cook, who was just about to pull the kitchen boy's hair because he had done something wrong, let him go and fell asleep. Finally, the wind died down so that not a single leaf stirred on the trees outside the castle.

Instead of dedicating a separate section of text to describing the different parts of the royal castle (hall, stable, kitchen, etc.), the narrative achieves this goal in a more dynamic way, by embedding the spatial information into the story of the court falling asleep. Similarly, the description of the lavish interior of the castle in "The True Bride" is preceded by a dynamic account of its construction, which also abounds in spatial information (ibid.: 539):

[T]he old woman touched the gray rocks. Immediately they began moving and slid together until they stood there as if giants had built the walls. The castle was erected on this foundation, and it was as though countless hands were working invisibly, laying stone upon stone. The ground groaned, and huge pillars arose by themselves into the air and aligned themselves next to each other. The tiles laid themselves down on the roof in their proper places, and by noon the large golden weather vane, in the shape of a young woman in flowing robes, had already begun turning on top of the tower.

Descriptised narration is often linked to the activities and movements of fairy-tale characters and objects (see below). For example, by tracing the spread of the titular treat in "The Sweet Porridge", the narrative gradually reveals new information about the heroine's home and its wider environment: as the porridge pours over the rim of 
the magic pot, it proceeds to "fill the kitchen and the whole house, then the next house and the street, as if it wanted to feed the entire world" (Grimm 2003[1857]: 345-346). "Spindle, Shuttle, and Needle" provides a similar example, as the energetic movements of the magic needle create a more detailed image of the interior of the heroine's cottage: "Then the needle jumped from her fingers and flew back and forth in the room as quick as lightning. [...] Soon the table and benches were covered with green cloth, the chairs with velvet, and the walls with silk curtains" (ibid.: 547). Spatial transference in particular serves not only to progress the plot but also to disclose spatial information by expanding the geographical scope of the narrative (see the section on characters).

The findings presented in this section suggest that, contrary to traditional views of the genre, descriptions are not antithetical to the (KHM) fairy tale. In other words, the genre's focus on action does not entirely come at the expense of descriptions. Rather, it determines their extent and type: while the Grimms' fairy tales do occasionally feature lengthier descriptive passages, they show a tendency towards brief, selective, functional descriptions and descriptised narration. The focus on action therefore does not automatically eliminate space, since a lot of spatial information is disclosed through descriptions of events. Moreover, the narrative provides explicit information about space whenever that is necessary for the plot.

\section{Characters as indirect means of establishing space}

In addition to the direct strategies of conveying spatial information discussed above, the fairy tale also relies on indirect means to establish space - specifically, references to the characters and objects that populate and constitute individual spaces. Fairytale characters serve to convey spatial information in several important ways: their identity, which implies the identity of the spaces they inhabit; their actions, which suggest the (positive/negative) qualities of a given space; their mobility (i.e. the spatial transferences they engage in); their perception; and their language and cognitive processes. Before discussing each of these character functions separately, it should be noted that, while the majority of spatial information is disclosed through reference to the protagonist, this does not mean that other characters do not serve to convey spatial information. As Chapter 3 argues, each individual character by their very existence implies the existence of a particular space, including the characters which are mentioned but not featured in the story (e.g. the sorceress in "The Frog King"). Furthermore, while the story usually follows the travels of the protagonists, they are not necessarily the only mobile characters in the story. On the contrary, a number of KHM fairy tales see several siblings set out on the same quest; even though the narrative is typically interested in the exploits of the youngest sibling, the older siblings, who make different choices and take different paths, also serve to 
convey relevant space-related information. For example, in "The Three Feathers", the travels of the older brothers are not documented, but what they bring back home from those travels (rings, rugs, and brides) points to the existence of various (nonmagical) spaces where those items and persons were obtained/encountered.

\section{Character identity and actions}

The identity of individual fairy-tale spaces is frequently implied through references to their inhabitants. In other words, the narrative may not explicitly name a particular space, instead suggesting its identity by naming the characters that populate it (cf. Dennerlein 2009: 116). The typical fairy-tale opening formula of "Once upon a time there was" is usually followed by an introduction of a character, commonly identified in terms of their occupation and social status, such as a poor woodcutter ("The Spirit in the Glass Bottle"), a farmer ("Hans My Hedgehog"), or a king ("Old Rinkrank", KHM 196) and queen ("The Donkey"; "The Twelve Brothers", KHM 9, ATU 451). In the absence of explicit spatial references, information about characters also serves as a prompt for readers to fill in the gaps by providing an appropriate setting for them (cf. Prince 1982: 43): a palace or castle for the king and queen, a cottage for the woodcutter or farmer. The omission of explicit spatial identification therefore does not negatively affect story comprehension since readers are provided appropriate clues (in this case, character identity) which allow them to automatically supply the missing information. References to inhabitants are primarily used to indirectly identify non-magical spaces - most notably, the initial, domestic space. In contrast, magical spaces are more likely to be explicitly named or identified via references to objects.

Attributes of spaces may be revealed through the characterisation of their inhabitants, often demonstrated through their actions. In other words, fairy-tale spaces are identified as supportive or hostile, pleasant or terrifying, through connections with characters and their actions: a forest populated by a cannibalistic witch or robbers who prey on unsuspecting travellers is a space of peril and threat, while the one inhabited by helpful dwarfs is established as a space of assistance and support. The link between space and character becomes especially prominent in cases in which the inclusion or exclusion of individual characters brings about drastic changes in the quality of space (discussed in more detail in Chapter 6): thus, the initially safe space of home can easily become hostile once an inimical step-parent enters it ("Cinderella", "Snow White"). Conversely, the elimination of a threatening figure (e.g. the stepmother in "Hansel and Gretel") can turn an initially dangerous space into a pleasant and supportive one.

The types of activities characters engage in within particular spaces and the objects they use also serve to identify these spaces and reveal more information about 
them. This is especially true of domestic spaces, in which individual rooms and areas are usually not named, but their presence is signalled through characters' actions. For example, the dwelling of the antagonist in "Old Rinkrank" is not explicitly described; however, the heroine's household chores such as washing dishes, cooking, and making the bed point to the existence of the different rooms in the house, or at least different areas dedicated to sleeping, eating, preparing food, etc. "The House in the Forest" provides a similar example, as the activities of the three heroines in and around the titular dwelling serve to expand our knowledge of that space. The narrative mentions a variety of chores and objects (a stove, table, bed, steps) that suggest specialised spaces and provide insight into the organisation of the house. The actions of the youngest sister (fetching food and water for the animals) expand the perception of the environment surrounding the house, which includes a well or some other water source close to the house and possibly a barn or other food storage facility.

From a spatial point of view, the importance of the characters - most notably the protagonists - derives from the fact that the narration is "attached" to them, meaning that the story mentions only empirical spaces, i.e. those the characters move through (Uspensky 1983[1970]: 58). Although, as Chapter 3 has demonstrated, the implied map of the fairy tale is much more expansive, only those parts that are relevant to the plot and actualised through characters' movements are mentioned. The importance of characters for "activating" individual points on the wider fairy-tale map is also recognised by Lüthi (1986[1947]), who argues that not only does the story mention only those locations which the characters move through, but their role in the story is closely linked to those characters: once they move on, the space is forgotten and no longer mentioned. Lüthi illustrates this principle with the example of the magic mountain, which serves as a repository of magic objects (1986[1947]: 40):

The function of the mountain was to help the hero get through his adventure. As soon as he has overcome his difficulties, the mountain loses this function and the folktale does not assign it another one. To the folktale, it is a matter of course that the mountain is no longer mentioned.

Since new locations are often introduced into the story when the protagonist visits them, spatial transference serves as an important means of expanding the geographical scope of the story (cf. Bal 2017[1985]: 219-220; Ronen 1986: 422, 424). By utilising protagonists' movements to demarcate narrative space and expand its scope, the fairy tale relies on what the sociolinguists Charlotte Linde and William Labov (1975) term the tour or route. Juxtaposing it with the map or survey, which is the representation of space from a fixed point, Linde and Labov define the tour as 
description from a mobile, dynamic point of view (1975: 927). Offering a static, external, and often disembodied perspective (e.g. an omniscient narratorial voice), the map divides the text into segments which are then gradually uncovered according to a specific system and direction. As such, it takes on the form of a direct description and typically relies on an "all-at-once approach", offering a panoramic view and setting the entire stage at the beginning of the story (Ryan 2003: 219). In contrast, the dynamic tour, which appears as descriptised narration, has a more narrative quality and presents information from the perspective of a mobile character (Linde \& Labov 1975: 927). The fact that new (spatial) information is typically introduced at the same time when it becomes known to the characters points to the significance of character experience and point of view for the story.

\section{Focalisation, verbalisation, cognition}

The fact that the story includes only the empirical space of the characters also suggests that their "point of view orients the narrative perspective" (Genette 1983[1972]: 186, original emphasis). This brings into focus the issue of focalisation, understood here as "the selection and restriction of narrative information relative to somebody's perception, knowledge, and point of view" (Jahn 2017: N3.2.1) ${ }^{70}$ In other words, the information presented in the story is inevitably filtered through and shaped by a particular point of view, be it the narrator (zero focalisation) or one or more characters (internal focalisation; Genette 1983[1972]: 189). Messerli states that the fairy tale features either zero focalisation of the narratorial instance who knows more than any of the characters, or internal focalisation (the narrator knows as much as the character; 2003: 360). While the KHM fairy tales are told by third-person, covert (cf. Chatman 1978), heterodiegetic narrators (cf. Genette 1983[1972]) who know much more than the characters and are only occasionally made overt through

70 For a more thorough discussion of the complex and often contested issue of focalisation, see, among others, Bal (2017[1980]), Genette (1983[1972]), Jahn (1996), Hühn, Schmid, and Schönert (2009), or Nieragden (2002). On focalisation in fairy tales see Bacchilega (1997: 71-102), who discusses Angela Carter's The Bloody Chamber), and Anna Katrina Gutierrez (2017), who analyses retellings of classic fairy tales. 
remarks about characters' behaviour ${ }^{71}$ or first-person codas, ${ }^{72}$ the presented perspective is nevertheless largely character-bound (Bacchilega 1997: 92). This means that the spatial coordinates of the story are primarily shaped by the characters' (especially protagonists') point of view - simply put, the story presents only what the characters see and otherwise experience. The reader therefore discovers new spaces along with the characters, as the spatial coordinates expand parallel to the expansion of the characters' empirical horizons. In other words, new spatial information is disclosed when the characters learn something new, visit a new location or gain a better overview of the current one (for example, by climbing a tree; Messerli 2005: 279). Despite the central importance of the protagonist, some fairy tales include the perspectives of multiple characters. "The Goose Girl at the Spring", for example, shifts from the old woman, to the count, then briefly to the queen, back to the old woman, then the titular goose girl and the count, ending with first-person narratorial guesses about the end of the story ("I believe that the beautiful princess married the count"; "I am not sure, but I suspect that this was the case"; Grimm 2003[1857]: 525).

The way individual spaces are depicted is also focalised through the characters, reflecting their perception and subjective impressions. In "Snow White", the queen orders the huntsman to take the seven-year old heroine into the forest and kill her. When the forest is mentioned in relation to the queen and the huntsman, it is not given any attributes; however, when the focal point of the story shifts to Snow White, the forest is described as "huge", as it is likely to appear to a frightened child (Grimm 2003[1857]: 182). Later, she comes across "a little cottage" filled with tiny furniture (ibid.):

Everything was tiny in the cottage [Ḧ̈uschen] and indescribably dainty and neat. There was a little table [Tischlein] with a white tablecloth, and on it were seven

71 The third-person narrator occasionally comments on the events, especially the behaviour of the characters, as in "The Water of Life" ("But the dwarf put a curse on him, and he ended up in a mountain gorge, where he became trapped like his brother. Indeed, that is what happens to arrogant people"; Grimm 2003[1857]: 328) or "The Poor Miller's Apprentice and the Cat" ("They thought that they had made a smart move, but we shall see what happens to men like that"; ibid.: 351 ).

72 Closing formulae in the Grimms' fairy tales often include first-person, at times also self-referential and meta-narrative observations intended to simulate the impression of oral narration or draw attention to the narrators who insist that their story is true ("Thereafter, he lived as happily as a lark with her, and whoever does not believe me must pay me a taler"; Grimm 2003[1857]: 382), share personal observations on the narrated events (e.g. wishing that they too had been invited to the wedding feast), or claim that they had in fact participated in them ("When the wedding took place, I was wearing a pair of glass shoes and bumped into a stone"; ibid.: 310 ). 
little plates. Each plate [Tellerlein] had a tiny spoon [Löffelein] next to it, and there were also seven tiny knives [Messerlein] and forks [Gäblein] and seven tiny cups [Becherlein]. In a row against the wall stood seven little beds [Bettlein] covered with sheets as white as snow.

While the consistent use of diminutives points to the physical size of the dwelling and its inhabitants (the seven dwarfs), it also reflects the point of view of both the inhabitants (who also use diminutives in reference to their furniture, cutlery, etc. ${ }^{73}$ ) and the child Snow White (diminutives are not used in later scenes with the queen). Similarly, the use of diminutives to designate the parental home (Häuschen) and its interior (das Stübchen/small room) in "Strong Hans" (KHM 166, ATU 650A, 301) reflects the perspective of the giant Hans, who at twelve years old is taller than his father. Changes in characters' point of view can modify or expand spatial information presented in the story. For example, in "The Twelve Brothers", the queen tells her youngest son that he and his siblings should run away to the forest and keep watch on top of "the tallest tree in the forest" (Grimm 2003 [1857]: 32); after the brothers find themselves in the forest, the tallest tree is identified more specifically as an oak.

As discussed in Chapter 3, characters' perspective also plays an important role in lending a specific environment the status of space. While something like a snail's shell or a hat may appear as an object to the human eye, it becomes a space when miniature characters such as Thumbling ("Thumbling", "Thumbling's Travels") explore their interior. Similarly, items such as bottles ("The Spirit in the Glass Bottle"), walnuts ("All Fur"), or eggs ("The Singing, Springing Lark", "The Crystal Ball") become spaces when it is revealed they are housing magical creatures or objects.

Finally, characters participate in the construction of space via their mental processes and verbal skills: they talk about and describe spaces, think about them, and envision them in their dreams. In cases like these, the verbal and mental representations of space typically function as anticipations of the actual spaces, which tend to appear in the narrative soon after they have been announced in this manner. Thus, if a character - like the heroine in "The Nixie in the Pond" - dreams about a space, they will soon set out on a trip and go there. Lüthi recognises the anticipation of things to come, usually in the form of dreams, objects (e.g. the portrait of the Princess of the Golden Roof in "Faithful Johannes"), or verbal anticipations (prophecies, prohibitions) as a staple of the fairy-tale genre (1987[1975]: 91). The

73 The dwarfs take turns wondering who had been sitting in their little chairs (Stühlchen), eating from their little plates (Tellerchen), using their little forks (Gäbelchen) and knives (Messerchen), and drinking from their little cups (Becherlein). 
latter also include various verbal itineraries, i.e. directions to and descriptions of specific locations, as well as instructions on how to behave and what (not) to do there. Cases like these allow characters to convey explicit spatial information instead of the third-person narrator (cf. Nünning 2007: 102-103). For example, the old woman in "The Three Little Birds" describes what the heroine will encounter if she keeps walking straight ahead: "you'll come to a large open castle. You must drop the stick on the threshold and go right through the castle and out the other side, where you'll see an old well. A big tree will be growing from the well, and on the tree a cage with a bird inside will be hanging" (Grimm 2003[1857]: 326). The narration which follows the old woman's description neither repeats nor expands on this description; rather, it only informs us that "[t]he girl found everything just as the woman had said" (ibid.). The character therefore assumes the narratorial role and provides other characters (and, by extension, the reader) with relevant information, which, having been conveyed dynamically (through characters' dialogue), is not repeated by the narratorial voice.

In addition to direct means of establishing space, the fairy tale also relies on indirect means of conveying spatial information. Prominent among them are references to characters: their identities and actions, their perspective, cognition, and verbal communication. On the basis of the characters' identities (especially their social status), readers can infer the identity of the space they inhabit, even when that information is not explicitly provided by the narrative. Furthermore, the traits of the characters and the actions they perform serve to characterise their environment, lending it positive or negative traits. Seeing that the narration is "attached" to the characters (protagonist), changes in their perception and experience also affect their (and, by extension, the readers') knowledge of space so that new spatial information is introduced into the story when the characters themselves learn more about their environment by exploring it, dreaming about it, or hearing about it from others.

\section{Objects and materials as indirect means of establishing space}

The identity and/or traits of individual fairy-tale spaces can indirectly be established through references to the objects and materials that constitute them (building materials such as stone, wood, or gold) and/or are used within them (various material items, from furniture to clothing and foodstuff). This can be achieved by explicitly naming individual items such as doors or windows to signify the larger space to which they belong, but which is not explicitly identified, or identifying and/or describing various objects and materials (primarily food and clothing) to establish the traits of a particular space. In the former case, the objects are a physical part of the space; in the latter, they may be its physical part (e.g. building materials) or 
contained within it. Since the synecdochal function of objects has already been discussed in the section on naming, the remainder of the present discussion will focus on the role of objects and materials contained within a particular space in establishing its traits.

On the most basic level, the presence of non-magical or magical objects can signal that the characters' current environment is part of the respective domain. In addition to magic objects, various rare and precious items and materials such as jewels, pearls, silver, and especially gold, which Lüthi associates with the magical (1987[1975]: 15), are used to indicate that the space the characters are occupying belongs to the magical domain or is of magical origin (e.g. the castle in "The True Bride"). For example, the gold, silver, and diamonds covering the tree leaves in "The Worn-out Dancing Shoes", or the jewels spread across the mountain top in "The Lettuce Donkey" all signal that these environments are part of the magical domain.

The qualities of individual spaces and the material conditions prevalent within them are often established through references to different types of food (or its absence) and clothes. Such objects assume the "value of a sign" for that space (Ronen 1986: 422), identifying it as a space of lack or abundance, poverty or wealth, safety or threat (abuse). Lack of food is often used to establish the initial domestic space as one of deprivation, as evidenced by, among other tales, "Hansel and Gretel", which opens with a description of a household on the verge of famine: "The woodcutter did not have much food around the house, and when a great famine devastated the entire country, he could no longer provide enough for his family's daily meals" (Grimm 2003[1857]: 53). With only "half a loaf of bread" left to feed the four family members, the parents try to alleviate the difficult situation by abandoning their children in the forest (ibid.: 55). Similarly, the father in "The Three Snake Leaves" is introduced as being unable to "provide enough food for his only son" (ibid.: 59), which prompts the protagonist to leave home in search of a better life. "The Virgin Mary's Child", a story which unfolds across a succession of spaces of lack and abundance, each of which is established through references to food and clothing, opens with a description of the material difficulties endured by the woodcutter's family, which is "so poor they could not have daily meals anymore and did not know how they would provide food for their daughter" (ibid.: 7). The lack of daily meals - or daily bread (tägliche Brot), as stated in the German original - unequivocally establishes the parental home as a space of lack and deprivation, poverty, and hunger. It is precisely this lack that provides a stimulus for the plot, prompting the Virgin Mary to offer her assistance and take the girl up to heaven.

In addition to the more obvious connotations of lack and impoverishment, food deficiency can also be used to establish a given space as one of abuse. Thus, a number of malicious fairy-tale step-parents express disdain for their stepchildren by limiting their access to (high-quality) food. For example, the siblings in "Brother and Sister" 
complain that their stepmother gives them "nothing but hard crusts of bread, just leftovers for food, and the dog under the table is better off. At least he gets a good chunk of meat to eat every now and then" (Grimm 2003[1857]: 38). Similarly, the heroine of "One-Eye, Two-Eyes, and Three-Eyes" endures hunger and thirst, and is given only leftovers.

Following the principle of juxtaposition, which states that spatial transference typically unfolds between contrasting spaces (Bal 2017[1985]: 127), the famished protagonists commonly move from their impoverished home into a space of (over)abundance: Hansel and Gretel, for instance, go from a house without bread to one "made of bread", which also has "cake for a roof and pure sugar for windows" (Grimm 2003[1857]: 56). Moreover, once they enter the house, they receive "a good meal of milk and pancakes with sugar and apples and nuts" (ibid.: 56-57). Similarly, the transportation of the titular protagonist from a poverty-ridden cottage to heaven in "The Virgin Mary's Child" brings about a positive change in the girl's fortunes; unsurprisingly, in heaven, "[e]verything went well for the girl [...]: she ate cake and drank sweet milk. Her clothes were made of gold, and the little angels played with her" (ibid.: 7). Clearly, the girl wants for nothing in heaven since this space - in contrast to the earthly realm - is characterised by opulence and material security. Once deprived of daily bread, she now enjoys cake (Zuckerbrot - literally, sugar bread) and sweet milk (süße Milch). In both "The Virgin Mary's Child" and "Hansel and Gretel", the initial deprivation is compensated for not only with the amount of food, but also its type, as the spaces of abundance provide rare delicacies such as cake and pancakes, suggesting that food is no longer merely a source of nourishment, but also pleasure.

The choice of sugary treats is perhaps unsurprising considering that sugar was for a long time "a rare and expensive luxury", found only on royal and aristocratic tables (Hagelberg 2003: 361). Another delicacy typically enjoyed within the magical domain is meat, a food also long reserved for those of higher social status owing to its high prices (Rozin 2003: 466) ${ }^{74}$ Roast meat and wine are served in the toad cottage in "The Iron Stove", while the titular "Mother Holle" provides her human helper with "roasted or boiled meat every day" (Grimm 2003[1857]: 89). Roasted, stewed or boiled meat is also a staple of magical objects that provide their owners with food, such as the magic table in "The Magic Table, the Golden Donkey, and the Club in the Sack" (KHM 36, ATU 563, 212), the tablecloth in "The Knapsack, the Hat, and the Horn", or the cupboard in "The Golden Children". Building on the link between gold (and other rare and precious metals) and the magical, a similar case

74 Unsurprisingly, the only non-magical space where meat is found is the royal court: in "Brier Rose", for instance, a roast is sizzling on the fire as the sleeping spell settles upon the castle. 
can be made for sugar, meat, and other rare and "precious" delicacies, which are typically only available within the magical domain. This notion is further supported by the fact that non-magical spaces of abundance are identified as such primarily through reference to ample quantities of food, rather than their type. For example, the abundance of the royal castle, where the protagonist of "The Virgin Mary's Child" is transported after agreeing to marry the king, is indicated by the statement that it provides the new queen with "plenty of everything" (ibid.: 9), which seems somewhat vague when compared to the references to sweet bread and milk she received in heaven. After marrying a knight, the heroine of "One-Eye, Two-Eyes, and Three-Eyes", who initially survived on leftovers, has "food and drink to her heart's content" (ibid.: 429). Both narratives mention specific types of food in connection with the magical, while being vague about the nourishment provided in non-magical spaces.

Not only is the presence of plentiful food sources and rare delicacies a frequent sign of the magical domain, but magical intervention can also transform spaces of deprivation into spaces of abundance. This is often achieved by gifting magical foodproducing objects such as tables, tablecloths, or pots to fairy-tale protagonists. For example, the household in "The Sweet Porridge" is initially established as one of extreme poverty and hunger, as the young protagonist and her mother have "nothing left to eat" (Grimm 2003[1857]: 345). However, the introduction of the magic pot (a gift from a mysterious old woman and brought into the house from the forest) that makes porridge instantly "put[s] an end to their poverty and hunger" (ibid.), turning the impoverished household into a space of (over)abundance.

In addition to food, sartorial items frequently serve to identify individual locations as spaces of wealth or poverty, security or threat. "Cinderella" offers perhaps the most famous example of this practice: as the heroine's home is transformed from a safe haven to a source of danger and abuse following the arrival of the stepmother and her daughters, the heroine loses "her beautiful clothes", and is forced to wear "an old gray smock" and wooden shoes (Grimm 2003[1857]: 79). The similarly humiliated heroine of "One-Eye, Two-Eyes, and Three-Eyes" must wear "shabby hand-me-down clothes", which are replaced with "beautiful clothes" in the home of her new royal husband (ibid.: 429). In "The Virgin Mary's Child", each instance of the heroine's spatial transference is accompanied by a change of clothing, which effectively points to the nature of the new space. The fact that the clothes she wears in heaven are golden points not only to the considerable improvement of her initial situation, but also to the magical origins of this new attire. Once the girl is banished from heaven and forced to live in the wilderness, her beautiful clothes gradually become torn, falling off in pieces until she is left completely naked, with nothing but her long hair to cover her body. Her ordeal comes to an end when a king takes her to his castle, where she is once again "dressed in 
beautiful garments" (ibid.: 9). As with food, sartorial items originating in the magical domain are typically described in more detail: Cinderella receives "a gold and silver dress and silk slippers embroidered with silver" from a magic tree (ibid.: 81), while the heroine in "All Fur" wears dresses that shine as the sun, are "as silvery as the moon" (ibid.: 241) and "as bright as the stars" (ibid.: 242). In contrast, the sartorial items originating in the non-magical domain tend to be described in less specific terms, as "royal" (ibid.: 34) or "rich garments" (ibid.: 170), or beautiful clothes.

While the various items of clothing, foodstuffs or food-producing objects typically serve as plot devices, allowing characters to conceal their identity, gain access to previously out-of-bounds spaces or improve their initial situation, they also indirectly convey various spatial information, particularly regarding the qualities of a given space. While not making explicit references to it, the narrative can therefore establish a given space as safe or threatening, deprived or abundant, by referring to the materials or objects used within it, especially items of clothing or food stuffs. The degree to which a particular item of clothing or type of food is specified can also indicate whether the space in question is magical or non-magical, with objects and materials featured in magical spaces typically being of the more precious variety and described in more detail.

\section{Spatial dimensions and distances}

This section explores the means by which the fairy tale establishes the dimensions of individual spaces and the relations - especially distance - between them. Traditional views of the genre, which consistently describe it as acartographic or unmappable (cf. Nicolaisen 1988, 1991), suggest that, given the narrative focus on the mobile protagonist, the story is more concerned with tracing the protagonist's movements, which also serve to largely delineate the spatial scope of the narrative, than providing concrete coordinates of its space. However, despite the lack of specific geographical parameters that would indicate the concrete position of each space within the wider spatial network, the narrative relies on various direct and indirect strategies to indicate the dimensions of individual spaces and the relationships between them, typically defined in terms of separation (here/there) and proximity or distance.

The spatial transference of the protagonist (and other characters) plays an especially important role in this respect, as it serves not only to activate individual parts of the fairy-tale world, but also to link them into a wider spatial network, creating transitions between otherwise disjointed spaces (Certeau 1988[1980]: 117). As an act of producing space, spatial transference "provides the basic indices for measuring space and time" (Bakhtin 2011[1937]: 105, original emphasis) in the fairy tale. However, as many scholars have pointed out, the fairy tale places less emphasis 
on the journey and more on the destination; in fact, as Propp notes, the entire process of spatial transference is often omitted (1990[1946]: 78), as protagonists are seamlessly transported across seemingly large distances and carried from one point in space to another in the span of a single sentence. Duda describes this type of instantaneous transference, in which movement is suggested rather than explicitly depicted, as a kind of journeyless journey, travelling sans the actual trip (2012: 85). The very act of transference thus becomes one big ellipsis, with the narration skipping from its starting point directly to the point of arrival, stating simply that a character set out on a trip and then arrived somewhere; in other words, the reference to the departure is immediately followed by a reference to the arrival, all within the same sentence (for example, "So he went on his way and finally came to a mountain where three giants were standing and quarreling"; Grimm 2003[1857]: 313).

However, despite the fact that its primary focus is moving the protagonist from one location to another, rather than the details of that move, the narrative may nevertheless offer some information about the duration of the trip, its itinerary, or means of its realisation, all of which (indirectly) provide information about the spaces in or across which it unfolds. When references to the specifics of spatial transference are made, it is usually to indicate that it is (very) long and strenuous, its final destination (very) far away and/or inaccessible. Taking spatial transference as its starting point, the fairy tale utilises a number of strategies to convey information about the dimensions of the spaces the characters move through and the relationships between them. These include creating an itinerary (listing the various spatial items separating the starting and end points of the transference), making references to magical means of transporting characters to their desired destination, and using concrete units of distance/length (albeit in a metaphorical way), verbatim repetition, and temporal references.

\section{Itinerary and magical means of transportation}

To indicate that two points in space are far apart, fairy tales may list individual places ("stations") the protagonists have to cross to reach their final destination. Duda describes this strategy as reducing the journey to an itinerary, presented as "a catalogue of stops without additional information on the process of travelling itself" (2012: 80). The stops themselves often provide settings for new quests, adventures, or encounters with other characters. In "The Devil With the Three Golden Hairs" or "The Griffin", for example, the protagonists go through several different kingdoms on their way to the devil's or griffin's house. While the distance between individual stops is not always specified, it is their sheer accumulation that generates a sense of great distance between the starting points of the heroes' journeys and their final destinations. 
Individual areas or groups of areas separating the point of departure from the destination are not always settings for adventures or encounters. Sometimes they are presented cumulatively, as a list of landscape items the protagonist must cross, rather than a list of stops, which increases the perceived duration of their trip. In that sense, the more "items" (fields, forests, meadows, etc.) mentioned, the larger the perceived distance. For instance, the protagonists in "Brother and Sister" walk "over meadows, fields, and stones" before reaching the forest (Grimm 2003[1857]: 38), while the journey of the titular "Prince Who Feared Nothing" leads "over hill and dale, through fields and forests" (ibid.: 396). When the itinerary lists fewer spatial items, they are often preceded by adjectives that highlight their nature, which again creates an impression of greater distance. For example, the flood in "The Nixie in the Pond" takes the heroine and her beloved to different parts of the world, so that "[h]igh mountains and deep valleys lay between them" (ibid.: 530). While the phrase identifies only two spatial items, they appear in an unspecified plural (mountains, valleys) and are described as especially difficult to cross (high, deep), all of which increases the sense of immense distance separating the characters. Moreover, the lack of precision in these types of itineraries (the number of mountains, valleys, meadows, etc. is never specified), coupled with the fact that many of them contain fixed phrases (e.g. "over hill and dale"), suggests that they should be understood as metaphorical expressions of large distance, rather than accurate lists of concrete areas the characters move through. That is to say, regardless of their concrete wording, these expressions always mean the same: that the mobile character journeys for a long time, crossing large distances in the process.

The large distances separating fairy-tale spaces can be indirectly expressed through references to the magical means of transportation needed to cross them. These distances are so immense that human characters cannot cross them by relying on human (non-magical) means and instead must seek out magical helpers who carry them into the magical domain or gifts them magic objects that serve as means of transportation. ${ }^{75}$ Especially prominent among the magic transportation objects are various items of clothing (e.g. cloak), footwear (seven-league boots), headgear (hat), and jewellery (ring), imbued with supernatural powers which allow them to carry their owner from one point in space to another in the blink of an eye. The transference is instantaneous and effortless (a manifestation of the "journeyless" journey): all the owners need to do is wish to be somewhere, or think of the place where they want to be, and they will find themselves there in the very next moment. In the Grimms' fairy tales, magic rings ("The King of the Golden Mountain", "The Drummer"), wishing hats ("The Crystal Ball"), enchanted boots ("The King of the Golden

75 For a classification of the different modes of transportation in fairy tales, see Kujundžić (2012b). 
Mountain"), cloaks ("The Lettuce Donkey"), and saddles ("The Drummer") all operate on the aforementioned travel-without-travelling principle. ${ }^{76}$ In addition to using magical objects, the human protagonist can be transported into the magical domain by a magic character: in "The Raven" and "The Drummer", giants carry human characters across large distances in their pockets or on the rims of their hats; in "The Golden Bird", the role of the magic transporter is assumed by a talking fox, who carries the youngest son into the magical domain on its tail. The fact that the places to which the protagonists are transported with the help of magic objects or characters can only be reached with magical assistance bespeaks not only their immense (albeit unspecified) distance but also their inaccessibility. The KHM protagonists often find themselves seeking places whose location is unknown to them, which means they depend on magical assistance to reach them. Magical spaces are therefore not necessarily very far away, but are frequently inaccessible to and concealed from non-magical characters, either physically (e.g. they are located underground, as in "The Three Feathers") or cognitively (their location is unknown, as in "The White Snake" or "The Crystal Ball").

\section{Units of distance and temporal expressions}

The Grimms' fairy tales rarely use concrete units of distance (length), opting instead for more abstract and metaphorical types of expressions discussed above. Even the few $\left(\operatorname{archaic}^{77}\right)$ units of distance that are mentioned - Meile (mile) and Elle (yard) ${ }^{78}$ - are used metaphorically rather than literally. Thus, units of distance are typically preceded by vague quantifiers such as "a few" or "a couple", or formulistic numbers such as seven, hundred, or thousand, which are often part of fixed formulae and/or used symbolically, to express "a totally abstract quantity" (Olrik 1965[1909]: 133). Therefore, phrases such as "thousand(s) (of) miles away" ("tausend Meilen weit weg"), featured in "The Brave Little Tailor" (the jealous soldiers wish the little tailor, who receives special treatment in court, would be "a thousand miles away"; Grimm

76 While the Grimms' tales do not contain examples of these, it should be noted that some objects can in themselves "represent the syncretic notion of the trip's distance and duration" (Ivleva 2009: 292). Specifically, the wearing off of items of clothing or footwear (e.g. iron shoes) during the protagonist's journey points to its extreme length and the large distance covered in the course of its duration.

77 Meile and Ellen became obsolete units of measurement following the introduction of the metric system to Germany in 1868 , which became obligatory by law in 1872 (cf. Putnam 1877). For a full list of now obsolete German units of distance, see Treese (2018: 130-133).

78 Despite the lack of precise correspondence, mile $(1.6 \mathrm{~km})$ and yard $(0.9 \mathrm{~m})$ have become conventional translations for Meile $(7.5 \mathrm{~km}$ on average) and Elle $(0.6 \mathrm{~m}$ on average) respectively (cf. Treese 2018: 132-133). 
2003[1857]: 76) and "The Raven" (the glass mountain is said to be "thousands of miles away"; ibid.: 317), should not be taken literally, but rather as expressions of unspecified large distances. Even expressions of smaller distances rely on this principle: "How Six Made Their Way in the World" (KHM 71, ATU 513A) features the phrase "two miles", which is repeated several times: the huntsman is trying to shoot out the eye of a fly sitting on the branch of an oak tree two miles away. He then joins the discharged soldier and they come across seven windmills. After "about two miles" (ibid.: 253) they come across a man who is blowing the windmills through one of his nostrils. Given its repetitive use, it might be assumed that this expression is also meant to signify (smaller) distance in general - i.e. that the two locations are separate from each other - rather than the precise length of two miles. Considering the context in which it is mentioned (men trying to shoot an animal and move windmills by blowing), the seemingly smaller distance appears much larger given the tasks that are being performed.

The importance of perspective comes to the forefront in the case of steps (Schritten), which, although not an official unit of distance, are used to indicate distance which is either very large - in the case of giants and similar magical creatures which can cross impossible distances "in a couple of steps" (Grimm 2003[1857]: 438) - or very small (things which are very close may be "just a few steps" away; ibid.: 444). While the number of steps (paces) remains small (but unspecified), the distance covered in "a few" or "a couple" of steps changes radically depending on who is walking: a giant or an ordinary human character. Numerical quantifiers used with steps - specifically, a hundred (those who come "within a hundred steps of the castle" of the powerful sorceress in "Jorinda and Joringel" immediately fall under her spell; ibid.: 248) and seven ("for every seven steps" the heroine of "The Singing, Springing Lark" takes, the bird leaves a drop of red blood and a feather to show her the way; ibid.: 294) - are typically formulaic and pattern numbers (cf. Lüthi 1987[1975]: 44-45), which may be interpreted symbolically.

Despite the occasional mentioning of concrete units of distance/length, fairy tales are more likely to convert space into time by using temporal expressions to establish spatial relations (Nicolaisen 1980: 16-17). In cases like this, time metonymically stands for distance (Lakoff \& Johnson 2003[1980:] 266) as the length between two points in space is not indicated through reference to the number of steps, miles, or yards that constitute it, but the amount of time it takes to cross it. Encompassing hours, days, and years, temporal references in the KHM fairy tales range from nonspecific ("a few hours"; Grimm 2003[1857]: 58, 495) to specific. Little Red Cap's grandmother, for instance, lives "out in the forest, half an hour from the village" (ibid.: 93), while the village in "The Six Servants" (KHM 134, ATU 513A, 900) is located "[h]alf an hour from the prince's castle" (ibid.: 439). "The Two Brothers" includes several instances of temporal expressions used to indicate distance: the 
mountain on which the rejuvenating root grows is "two hundred hours" (ibid.: 219) away from the characters, the royal castle is "about a three-hour walk" from the enchanted forest (ibid.: 226), while its different gates are "an hour's walk apart" (ibid.: 227). The use of hours as a metonym for distance is perhaps not entirely unexpected as Wegstunde (an hour of travel) - the equal of half a mile - was for a long time an accepted unit of distance in Germany, often used to mark the length of roads (Treese 2018: 293). Fairy tales also use temporal references to express road length, as evidenced by "The Two Travelers", which features two forest paths: one takes seven days to cross, the other only two.

References to days typically express distance by stating that characters walked the whole day (e.g. "The Twelve Brothers", "The Maiden Without Hands") or (less frequently) the entire night and the whole day ("The Six Swans") before reaching their destination. They are also often used to establish the dimensions of space by expressing how many days it takes to cross it. For example, the forests in "The Two Brothers" and "The Expert Huntsman" are so huge that they are "impossible to cross in one day" (Grimm 2003[1857]: 214).

The most common year-based expression used in reference to space is seven years, which is how long the king in "The Maiden Without Hands" and the heroine of "The Singing, Springing Lark" wander around the world in search of their spouses. References to other temporal units, such as months, weeks, or minutes are used less frequently to indicate space. The latter appears only in connection to transference on horseback (as opposed to the majority of the above listed examples which refer to travelling on foot): the count's daughter in "The Glass Coffin", for instance, reaches her destination "in a few minutes" because she is riding a horse (Grimm 2003[1857]: 485).

\section{Repetition and audio-visual signals}

Another strategy utilised to create - or, rather, highlight - a sense of distance in the Grimms' fairy tales is iteration or verbatim repetition. Although this may seem at odds with a genre as linguistically economical as the fairy tale (Lüthi 1986[1947]: 25), the KHM narratives do occasionally repeat individual words - most notably adjectives and adverbs - in order to intensify the meaning of the basic phrase (Messerli 2005: 278). This type of stylistic repetition ${ }^{79}$ is based on the notion that "more of form is more of content" (Lakoff \& Johnson 2003[1980]: 127); thus, as Lakoff and Johnson explain, phrasings such as "He ran and ran and ran and ran"

79 Stylistic repetition should be distinguished from structural repetition in fairy tales, which refers to the repetition of individual episodes and other plot elements (Lüthi 1987[1975]: 93-94). 
suggest "more running than He ran" (ibid.). Following this principle, the repetition of the initial adjective/adverb in phrases such as to wander "a long, long way" ("lange lange gegangen"; Grimm 2003[1857]: 39) or journey "far, far away" ("weit weit"; ibid.: 92) intensifies the length indicated by the basic phrase (in other words, "far, far away" suggests greater distance than just "far away"). ${ }^{80}$

Finally, dimensions of space can be established independently of spatial transference. Specifically, the various acoustic and visual signals that the magical often uses to lure the non-magical into its midst can also have a "space-constructing function" (Messerli 2005: 279), in view of their ability to travel through space, thus expanding its scope. The light in the distance, for instance, adds a new dimension to the forest, increasing its size and depth. The same is true of various acoustic signals, such as the sounds of pig slaughter in "Hans My Hedgehog", which can "be heard for miles around" (Grimm 2003[1857]: 363), or the distant splashing of water in "The Nixie in the Pond", which leads the miller to the magic pond. The type and resonance of a sound determine the extent to which the audio signals increase narrative space (e.g. a low whisper suggests proximity, while the resounding toll of church bells can be heard for miles away; Bal 2017[1985]: 125).

Although the fairy tale lacks a concrete geography characterised by precise coordinates, the dimensions and basic relationships between individual spaces typically expressed in terms of proximity or distance and (in)accessibility - are established in various direct and indirect ways. Since individual locations are usually linked via protagonists' spatial transference, the aforementioned dimensions and relationships are commonly established through references to that transference. While spatial transference often takes the shape of a "journeyless" journey, meaning that the narrative focuses only on the destination, omitting the actual movement through space, references may be made to its duration, itinerary, or the means of its realisation, all of which also convey spatial information. The duration of the journey may be indirectly expressed by creating an itinerary, i.e. listing the spatial items or

80 It should be noted that iteration is sometimes absent from the German original and is only introduced in the English translation, perhaps motivated (like the Grimms themselves) by the wish to enhance the oral quality of the text or promote a kind of perceived style of the traditional fairy tale (cf. Van Coillie 2014). For example, the phrase "farther and farther" is added in the English translation on several occasions to highlight the duration of the protagonists' journeys. This is the case in "The Singing, Springing Lark", where the heroine "went farther and farther into the wide world" (Grimm 2003[1857]: 294; Ger. "ging sie immerzu in die weite Welt hinein" [she kept going out in the world]) and "The Goose Girl at the Spring", which sees the heroine move "[o]ver the meadow toward the valley, farther and farther" (ibid.: 523; Ger. "über die Wiesen immer weiter bis in das Thal" [over the meadow and onwards, to the valley]). In both examples, non-repetitive phrases used in the German text (immer $z u$, immer weiter) are replaced with repetitive ones in the English translation. 
stops on the way between the initial and final point. In some cases, the distance and precise location of the desired (magical) destination are not explicitly stated, but the fact that it can only be reached via magical intervention (usually in the form of magic transportation objects) suggests that it is (physically and/or cognitively) concealed from human characters and/or located at an extreme distance which cannot be conquered by human (non-magical) means. To express (large) distance, fairy tales often rely on iteration or use units of distance, which are either unspecified or meant to be taken metaphorically rather than literally. Finally, the dimensions of spaces and distance between them can also be established by referring to the duration of the characters' spatial transference (again, often expressed in metaphoric rather than literal terms) or various visual (light) and audio signals.

When they are referred to, dimensions of and relationships between spaces are typically expressed in terms of proximity or distance and (in)accessibility. While the KHM narratives often omit references to the actual journey, mentioning only that the mobile character left a particular place and immediately arrived at a new one, information about the spatial transference - and, subsequently, the space in which it unfolds - is provided when that is relevant for the story. In quest narratives in particular, the immense distance that separates the protagonist's starting point and final destination highlights the difficulty of the quest as well as the necessity of magical intervention for its successful accomplishment. Since the duration of a journey also points to the efforts required to complete it (Tuan 2008[1977]: 129130), travelling far and wide serves as a testament to the mobile character's dedication and determination to succeed. Likhachev makes a similar claim as part of his argument about the superconductivity of fairy-tale space when he points out that distance in fairy tales does not serve to hinder the progress of the protagonist (and, by extension, the story) but to "bring a large scale, a significance, a peculiar spirit into it. The significance of what is happening is estimated by space" (2014[1967]: 329). However, not all fairy-tale spaces are impossibly far apart. In cases when spaces are identified as being close to each other or the distance between them is not mentioned, the emphasis is primarily on their separation: in other words, it is less important whether the characters travel north or south, near or far, as long as they leave their current environment ("here") and go somewhere else ("there").

\section{Conveying information about space in the fairy tale}

As this chapter has argued, the fairy tale's focus on action and stylistic parsimony do not entirely come at the expense of space-related information. Rather than lead to its exclusion, the aforementioned genre traits simply affect the ways in which spatial information is communicated. Thus, much of the information about individual spaces and their qualities are established indirectly, through reference to characters 
that inhabit or move through them and the objects they contain, which rely on readers to fill in the spatial information which is not explicitly provided. The spatial extension of the story is constantly expanded as the narrative continuously reveals new space-related information, even when its focus is elsewhere (on the action and/or characters). Furthermore, despite the oft-cited incompatibility of the genre with descriptions, the KHM fairy tales do contain both lengthier descriptive passages and brief, select descriptions, which usually take the form of one or two highlighted adjectives, or brief postmodifier phrases. Its reliance on indirect strategies and overall lack of details about the described spaces suggests that the fairy tale relies on what Nünning terms a top-down, frame-driven approach to constructing space (2007: 99). Unlike the bottom-up, data-driven approach, which necessitates a multitude of details about the described objects, the top-down approach means that that the narrative focuses on select explicit references to space which serve to "cue [...] readers to activate the appropriate contextual frames" (ibid.).

The choice of individual spaces, their constitutive parts (doors, windows, etc.), and traits which will be explicitly identified is dictated by the plot (the frame in Nünning's frame-driven approach; 2007), meaning that only those spaces, spatial items, or spatial traits which are of immediate importance to the plot will be identified. Thus, if the narrative explicitly states that, for example, the miller lives in a mill (even though the reader can infer as much) it means that the mill itself will serve as a plot device. In addition to plot relevance as an important factor that determines the type and extent of spatial information, the compatibility of a given space with the protagonist's - and, by extension, audience's - everyday experience also plays an important role in this respect. With the exception of the castle or palace, non-magical spaces are often identified through indirect means and described in less detail than magical spaces, since the narrative relies on readers to draw on their own knowledge and experience to fill in the gaps. In contrast, magical spaces stand outside the empirical knowledge of the characters or readers and are therefore typically established more explicitly and in more detail. The special status of regal spaces - which are often given considerable attention - within the non-magical domain, may suggest that they too are not part of the implied audience's experience, meaning that the people developing and sharing fairy tales may have been members of the lower classes, for whom castles and palaces - which they had no direct experience of - embodied the highest values.

In addition to bringing the traditional view of the lack of spatial information in fairy tales into question, the observations presented in this chapter challenge the notion that space is always in the background. Rather, direct strategies of spatial representation - especially direct description - bring space to the foreground, turning it into "an object of presentation [...] an acting place rather than the place of action" (Bal 2017[1985]: 127). While fairy-tale space is generally viewed as subordinate to 
the story, in cases of its foregrounding, "the fabula becomes subordinate to the presentation of space" (ibid.). Space can also come to the foreground as an object of presentation in cases when events and character actions influence their environment. Dennerlein terms such situations in which an event - understood as both a happening or occurrence, and an action - changes the environment in which it unfolds situational or event-based thematisation of space ("ereignisbezogene Thematisierung von Raum"; 2009: 118, 123). ${ }^{81}$ In addition to their role in identifying, characterising, or introducing new spaces to the story, characters can therefore also alter and physically manipulate spaces by creating, expanding, limiting, or eliminating them, often via magical assistance. For example, protagonists may be asked to chop down a forest ("The Drummer"), remove a mountain ("The Two Kings' Children"), or build and furnish a castle in a single day ("The True Bride"). Magic can also be used to alter the size of space, as evidenced by "The Glass Coffin", in which an entire castle and its surroundings are shrunk and placed inside a glass display case. In some cases, space is completely transformed into a different, more luxurious living environment: in "The Poor Miller's Apprentice and the Cat", for example, a small cottage built with silver tools is transformed into "a huge castle" in which everything is "made of silver and gold" (Grimm 2003[1857]: 353). "The Goose Girl at the Spring" provides a similar example in which a "little house" is "transformed into a splendid palace", complete with a royal table and helpful servants (ibid.: 525). Characters themselves can transform into spaces and spatial items, such as churches, ponds, or hedges ("The Two Kings' Children"; "Foundling", KHM 51, ATU 313; "Sweetheart Roland", KHM 56, ATU 1119, 313, 407). Magic can also be used to demolish space, as illustrated by "The Knapsack, the Hat, and the Horn", which ends with an almost total destruction of the protagonist's surrounding: "All at once everything collapsed - the walls, the fortifications, the cities, and the villages", and had the protagonist not stopped blowing his magic horn, "everything would have been devastated, and not a single stone would have remained standing on top of another" (ibid.: 193).

While the present chapter discusses them separately, individual fairy tales often combine the different indirect and direct strategies to convey different types of

In her dissertation, Marlene Karlsson Marcussen (2016) expands on Dennerlein's notion of event-based thematisation by pointing out that an event is not merely something performed by characters. On the contrary, it is also something that "happens with the space exclusively on a material level" (Karlsson Marcussen 2016: 63, original emphasis). In other words, in cases of its transformation or description, narrative emphasis shifts from character actions to the space, which itself becomes an event, "something actively happening" (ibid.: 252, original emphasis). Viewed from this perspective, space is independent of characters, able to create plot and movement by gathering, and relating things and characters. 
spatial information. For example, "The Lettuce Donkey" reveals several key pieces of information about the mountain the protagonist visits with his sweetheart: its name (Garnet Mountain/Ger. Granatenberg), inaccessibility (it cannot be reached without the help of a magic wishing cloak), quality ("the wild mountain"; Grimm 2003[1857]: 402), inhabitants ("the wild and monstrous giants [...] who were always up to mischief"; ibid.), and the objects it contains (precious jewels). Its inaccessibility, link to precious jewels, and magical quality of its inhabitants all point to the position of this space within the magical domain. The use of the adjective "wild", coupled with the characterisation of the giants, suggests that the mountain is a space of threat and danger, one that will - through the actions of the characters become a site of deception. Realised as a "bundle[...] of distinctive features" (Jason 1977a: 107), the space of the mountain is therefore construed through a dynamic interaction between both implicitly (references to characters, objects, and materials) and explicitly conveyed information. This notion that space is a product of relationships between characters, objects, and other spaces (Herman 2002: 298), something that is continuously being (re)created through an interplay with different narrative elements, points to a more complex and dynamic process of space production, and challenges the notion of narrative space as static.

The dynamic nature of space is seen not only through its production through multiple relationships, but also its impact on the objects it contains and the characters that inhabit or move through it. While the relationship between characters and space will be discussed in the next chapter, the present discussion has highlighted the link between space and objects. Thus, objects featured within the non-magical domain are often identified in general, rather than specific terms (e.g. garments instead of dresses, or food instead of meat or cake) and are usually not described. In contrast, objects used within the magical domain are more commonly specified and described, often in superlative terms.

The following chapter further develops the concept of space as a dynamic, active narrative element, one that is the product of multiple complex relationships. Drawing on both fairy-tale scholarship and research connected with the spatial turn, it proposes to examine the interplay between space and other narrative elements especially characters - in more detail, and explore the general traits of narrative space in the fairy tale. 


\section{Qualities of Fairy-Tale Space}

While the previous chapter explored the means by which narrative space is represented in fairy tales, the present chapter focuses on its qualities. By examining the concrete characteristics of fairy-tale space it challenges traditional views of space as a narrative element which does not exist independently of the action and characters, and whose role is reduced to that of a passive background for events, which neither affects nor is affected by the action for which it provides the setting. The present research instead proposes that narrative space is a dynamic and active component of the fairy-tale narrative, which is not only shaped by the characters and action but, in turn, shapes them as well. In doing so, it adopts the new understanding of space (prompted by the spatial turn) as mutable and open-ended, continuously (re)produced through different (social, cultural, material, etc.) relations (see, for instance, Lefebvre 1991[1974]; Massey 2005; Soja 1989).

Although ideas about space produced by research associated with the spatial turn have not been directly applied to the study of fairy-tale space, some scholars have reached similar conclusions about its qualities without explicitly engaging with the spatial turn. Likhachev (2014[1967]) describes fairy-tale space primarily as superconductive, allowing for action to develop easily. As such, its role is primarily as an environment for movement and other types of character activities: it is essentially boundless and can be expanded without limit. Most significantly for the present research, Likhachev also finds the fairy-tale environment to be active and dynamic: "[i]t creates an environment for movement, and itself changes and moves" (2014[1967]: 327). This research expands on this idea and claims that the link between space and movement (spatial transference) - specifically, the characters who engage in that movement - is a complex, two-way relationship in which characters shape their environment and are, in turn, shaped by it. Haase (2000) makes an important claim regarding the nature of fairy-tale space, which, he writes, is essentially ambiguous. In other words, individual spaces do not have fixed roles and attributes, but take on different characteristics depending on the specific narrative in which they are featured (Haase 2000: 363-364). The observations presented by both authors suggest that space is not fixed but relational, as its qualities and role in the story change through its interaction with other story elements (characters, plot, etc.). 
Like Likhachev, Messerli comments on the ability of fairy-tale space to both expand and contract (2005: 278), and describes it as essentially discontinuous in nature (ibid.: 281). The said discontinuity primarily stems from the fact that spatial information is revealed through the movements of the protagonist, which gradually expand the spatial scope of the narrative by actualising select locations which are only connected via the mobile protagonist. However, even these seemingly disconnected locations, while localised and defined only loosely, are nevertheless defined in relation to each other, typically in terms of proximity or distance.

Building on existing observations on the spatial traits of fairy tales, primarily those presented by Likhachev (2014[1967]), Haase (2000), and Messerli (2005), each section of this chapter explores a different spatial trait, starting with that most commonly cited, its abstract, unspecified nature. The following section explores the discontinuous and unmappable quality of fairy-tale space. The chapter then proceeds to ask whether, given the lack of specific coordinates and the widely accepted notion that the genre's setting has no bearing on the plot, the concrete identity of that setting is entirely irrelevant, i.e. whether the story can indeed take place anywhere. The following section discusses the ambivalence of fairy-tale space, arguing that individual spaces do not have fixed attributes, but change from story to story and even in the course of the same story. Finally, the chapter examines space as a dynamic and relational narrative element, one which is not only influenced and changed by other story elements - most notably characters - but can also influence and change them.

\section{Unspecified and unlocalised}

As this thesis has already pointed out, an oft-repeated claim within existing scholarship regarding fairy-tale space - specifically, the setting - refers to its abstract and unlocalised quality. In fact, the unspecified setting is associated with the genre to such an extent that it often serves as a point of differentiating the fairy tale from other genres, most notably the legend, which is often set in historical times and includes references to concrete geographical locations, bearing a distinctly local, regional, or national stamp (this is especially true of historical and place legends; Klintberg 2010: 13). Some of the Grimms' tales even show a kind of meta-awareness of this lack of concern for geographical specifics. For instance, in "Faithful Ferdinand and Unfaithful Ferdinand", the king sends Faithful Ferdinand on a quest to find his beloved, who is "in such and such a place" (Grimm 2003[1857]: 412); similarly, "The Griffin" opens with the following sentence: "There was once a king, but where he ruled and what his name was, I do not know" (ibid.: 488).

The abstract quality of fairy-tale space is less predicated on the amount of spatial information provided about them (which, as the previous chapter has demonstrated, 
can at times be extensive), and more on the non-specific nature of that information. While the fairy-tale forest may be established as large, dangerous, magical, or dark, it nevertheless remains $a$ forest, situated somewhere within the larger world of the fairy tale. Thus, even spaces that are identified and/or described use common rather than concrete nouns or toponyms, and general, repetitive adjectives.

On the whole, toponyms are rarely featured in the KHM, especially when compared to other fairy-tale corpora, such as the The Thousand and One Nights or Basile's Pentamerone, which contain more numerous and more explicit geographical references (cf. Canepa 1999; Henninger 1949; Leeuwen 2007). Specifically, the collection contains only a handful of concrete - predominantly German - geographical references, including the city of Bremen ("The Bremen Town Musicians", KHM 27, ATU 130), Switzerland, Rome ("The Three Languages", KHM 33, ATU 517, 725, 671), Hohenfurt (“Gambling Hans”), Mount Köterberg and the River Weser ("The Three Little Birds"), the Moselle River ("The Seven Swabians"), the Red Sea ("The Six Servants"), East India ("The Three Black Princesses", KHM 137), Lower Pomerania ("The Little Shepherd Boy", ATU 152, ATU 922; the toponym is only mentioned as part of a riddle), and Buxtehude Heath ("The Hare and the Hedgehog"). The lists of exaggerations presented in the tall tales "The Tale About the Land of Cockaigne" (KHM 158, ATU 1935, 1930) and "A Tall Tale From Ditmarsh" (KHM 159, ATU 1935, 1930) also include references to realworld locations, such as Rome, the Rhine, and Regensburg. However, some scholars have argued that such toponyms are typically used more for their symbolic potential than as references to real-world geography. For example, Schmiesing suggests that the reference to "East India" (Ostindien) in "The Three Black Princesses" is meant to evoke associations with black-and-white colour symbolism which is at the forefront of the story, geopolitical events of the late eighteenth to early nineteenth century, and "considerations of race and ethnicity" (2016: 227). In that sense, the toponym primarily signifies "other", colonial spaces, rather than India itself. Tatar offers a similar explanation for references to Bremen in "The Bremen Town Musicians" (which never actually appears in the tale) by pointing out that its significance for the story lies less in the actual city and more in its status as a seaport: as such, it "represents a blend of the domestic and the exotic, a liminal space that combines home and abroad and that figures as a point of departure for life's final journey" (2004a: 150, n.1). ${ }^{82}$ The Grimms themselves explain some of the toponym choices in their notes to the tales: for instance, they expound on the appeal of Mount

82 Rölleke offers a contrasting view, claiming that the choice of location in the tale is both important and deliberate: Bremen is a town known for music, so the fact that the elderly animals want to go there to display their musical "talents" can be read as a form of mockery (2002: 296-297). 
Köterberg ("The Three Little Birds") as the setting for a fairy tale (as well as numerous legends) by referring to its liminal position at the meeting point of three German counties, as well as its natural properties (overgrown with forests, very high, etc.; 2007[1822]: 1034). In other cases, toponyms may be used as a homage of sorts to the contributor of the tale and his or her origin; for example, Uther suggests that the Swiss setting of "The Three Languages" may be ascribed to the fact that the person who told the story to the Grimms, Hans Truffer, was from a town in Switzerland (2013[2008]: 82).

The abstract quality of fairy-tale space refers to both its overall spatial framework (i.e. where the story is set) and its internal geography: on the one hand, the narrative rarely provides concrete geographical markers that would allow readers to situate it within an extra-literary framework (and even when it does, it often uses them in a metaphorical rather than literal sense); on the other hand, as the previous chapter has demonstrated, the internal organisation of the fairy-tale narratives, i.e. the relationships and distances between individual spaces (as well as the overall spatial scope of the story) are also vague, making it difficult for the reader to connect them into a comprehensive map. In both cases, space is defined primarily through the lens of the here-there or here-away dichotomy ("there" often but not always being far away). The setting is therefore established as simply being "away" (i.e. not here), or "somewhere else" (Cooper 2004: 71) in relation to the "here" of the audience, i.e. as spatially and temporally distant from them. Thus, while being vague and unspecific, the proverbial "far far away" tells the audience all they really need to know: that they are being transported "into a non-real realm, the realm of literature", which is both physically and experientially distant from their own (Lüthi 1987[1975]: 49). Moreover, the appearance of magical events and characters, and their acceptance as a "normal" part of the fairy-tale world, also suggests empirical distance (in other words, occurrences incompatible with the reader's empirical reality are presented as part of the everyday experience of the fairy-tale protagonist). Its depiction of what the audience recognises to be impossible as possible further solidifies the notion that the fairy-tale world is distant from that of the audience on multiple levels, making its anchoring in concrete geography both impossible and unnecessary. The fact that the story takes place "somewhere else" is important because it invites the suspension of disbelief, suggesting that, since the portrayed world is clearly not the empirical world of the audience, they can accept that it operates under different rules.

\section{Discontinuous and unmappable}

As the discussion on the dimensions and relationships between individual fairy-tale spaces presented in the previous chapter has indicated, the juxtaposition among 
individual spaces can be described in terms of "here" and "there/away", the latter being distinctly separate and often far away. In other words, the narrative rarely informs readers about the direction in which the protagonists travel or the concrete distances they cover, merely that they move from one location to another. Since the key aspect of the relationship between individual spaces is their separation, the narrative is not concerned with establishing concrete spatial coordinates and specific information about where precisely individual spaces are located in relation to each other.

The said lack of concern is perhaps best exemplified by the frequent irregularities in establishing the position of the various magical spaces on the vertical/horizontal axis. A frequently cited example of this practice is the Grimms" "Mother Holle" (cf. Messerli 2005: 275). The fact that the legendary titular figure causes the snow to fall on earth by making her bed suggests that the magical realm she inhabits is situated somewhere in the celestial sphere, perhaps among the clouds (as envisioned by numerous illustrators, such as Robert Weise or Otto Ubbelohde; see Figure 4.). However, the way to Holle's house in the story leads the heroine down a well. The text further complicates this position when the girl expresses her wish to go back up to earth ("ich muss wieder hinauf"), even though she likes everything "down here" ("hier unten"; Grimm 2009[1857]: 89). Having completed her apprenticeship at Holle's, she finds herself "back up on earth" ("befand sich oben auf der Welt"; ibid., emphasis added). Similarly, heaven (in both the religious and physical sense) and hell in the KHM can often be reached by walking straight ahead for a long time (e.g. "The Seven Ravens", "The Devil's Sooty Brother"), rather than moving upwards or downwards. On the one hand, this reinforces the notion that these spaces have been emptied of their religious content and turned into "ordinary" magical spaces, which share the same function and semantic "weight" in the story as the golden kingdom, glass mountain, or enchanted forest (Brückner 1990: 1044). On the other hand, it also highlights the significance of physical separation and the here-away dichotomy. Thus, the important thing is that the magical space is different and separate from the protagonist's domestic environment; however, where exactly it is situated on the horizontal/vertical axis is of secondary importance, meaning that it is less important whether the protagonist moves up or down, north or south, as long as they move away from their initial environment. 


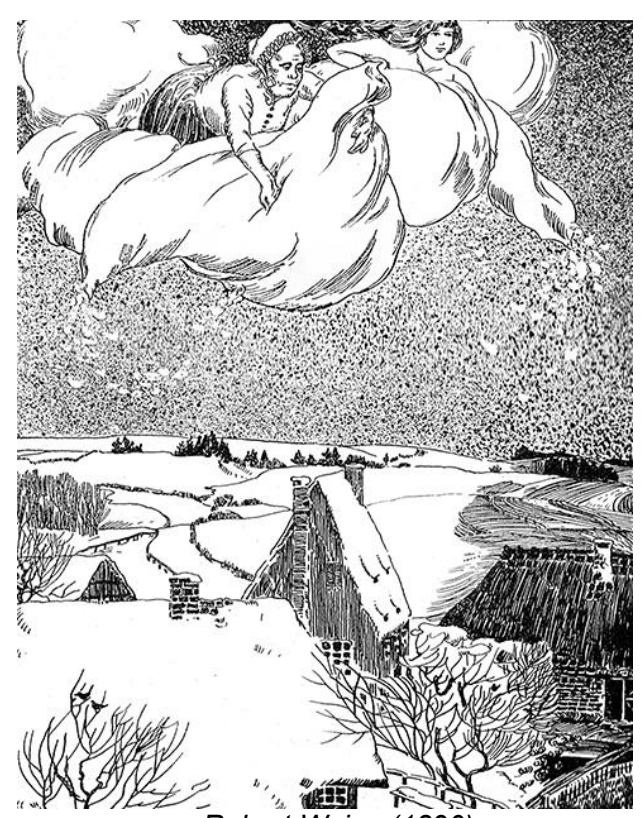

Robert Weise (1890)

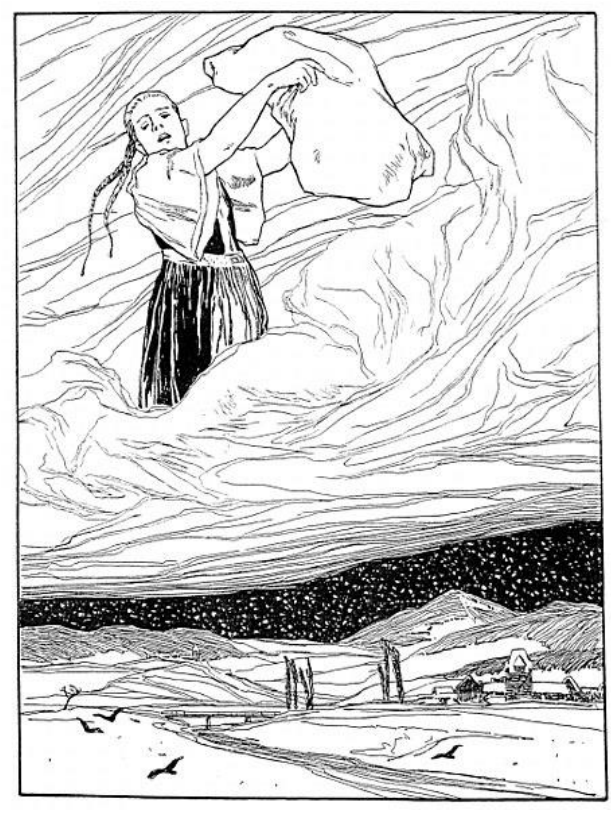

Otto Ubbelohde (1907)

Figure 4. Illustrations of "Mother Holle" 83 .

The lack of concrete coordinates accounts for an environment that can be described not only as abstract, but also unmappable and discontinuous, consisting of isolated locations which are connected only through characters' movements (Messerli 2005: 277). As the central narrative focus, the transference of the characters (primarily the protagonist) serves to connect the otherwise disconnected locations into a wider spatial network. The narrative therefore primarily "follows the co-ordinates of adventure" (i.e. the protagonists' movements) rather than mappable space (Cooper 2004: 71), which accounts for the genre's acartographic nature. The fairy tale itself seems to acknowledge its own unmappability by forgoing any attempt at visual representation of its geography in the form of maps. ${ }^{84}$ In fact, only one tale in the primary corpus, which shows a distinct predilection for verbal rather than visual mapping, features maps. In "The Raven", a giant tries to help the protagonist find the golden castle of Mount Stromberg by searching for it on a map which "shows all

83 Source of images: "Frau Holle (Illustrationen), https://grimmbilder.fandom.com/de/ wiki/Frau_Holle_(Illustrationen).

84 Maps have been attracting increasing attention within folklore and literary scholarship, both as objects of research (Ekman 2013; Sundmark 2014; Goga \& KümmerlingMeibauer 2017) and analytical tools (a growing research niche is dedicated to mapping literary spaces; see, among others Broadwell \& Tangherlini 2016; Moretti 1998[1997]; Piatti et al. 2009; Tally Jr 2014; Tangherlini 2010). 
the cities, villages, and houses" (Grimm 2003[1857]: 317). However, even this supposedly all-encompassing map does not reveal the desired location.

As previously noted, the lack of concrete geographical coordinates and specific localisation has led many to conclude that the fairy tale takes place "nowhere in particular" (Chatman 1978: 106). Bottigheimer points out that the Grimms themselves understood the fairy tale as a genre that is not bound to a specific time or place, which is why they purposefully avoided place- and time-specific vocabulary (1988: 199). This raises the question, if fairy-tale narratives are timeless and placeless in the sense that they are not rooted in a concrete historical and geographical framework, does that mean that their temporal and spatial coordinates are irrelevant? Moreover, if the fairy tale is not bound to a particular location and if the location it does take place in presumably does not affect the action, can it take place in any location? Does this lack of geography account for what might be called a pan-geography?

\section{Pan-geographic (?)}

The oft-repeated claim that space in fairy tales is little more than a background for the action which in no way affects the plot suggests that the concrete identity of its individual spaces is irrelevant. In other words, if the most important thing is what happens, rather than where it happens, than the specifics of where might appear entirely incidental. In that scenario, one space could easily be substituted with a different one without that substitution altering the events in any way. For example, the encounter between the protagonist and the magical donor might just as easily take place on a meadow or seashore, as in the forest or wilderness, meaning that if the encounter was transplanted from one environment to another, that would not alter its outcome. Furthermore, the fact that it is apparently set nowhere in particular might also suggest that the fairy tale can take place anywhere, a notion which finds support in Lüthi's (1986[1947]) argument that any theme or motif can be absorbed into the fairy-tale narrative and given a "fairy-tale" quality. If any setting can be appropriated by the fairy tale, then the fairy tale can surely take place anywhere.

This supposed interchangeability and arbitrariness of spaces is often cited in connection with adventure-oriented, plot-driven genres (such as the fairy tale) in which events take centre stage. Bakhtin identifies it as a feature of the adventure chronotope (2011[1937]: 100), while Helen Cooper discusses it in connection with the romance (2004: 70). Since the action in such narratives does not include interaction with the spatial background (the specifics of which appear to be almost irrelevant) but merely unfolds against it, and since the focus is on the action rather than its setting, one can easily conclude that space in these types of narratives is of secondary importance. If space really is so irrelevant, it might be concluded that the 
story could take place anywhere, a notion encapsulated in Elizabeth Leane's term "anywhere" settings (2016: 26). However, this concept is not without its problems.

In his discussion of the Greek romance novel, Bakhtin comments on the interchangeability of the genre's spaces, observing that "what happens in Babylon could just as well happen in Egypt or Byzantium and vice versa" (2011[1937]: 100). However, he admits that there are some limits to the interchangeability and apparent arbitrariness of the spaces featured in these narratives. On the one hand, shipwrecks can only happen at sea; on the other hand, the concrete identity of the sea "makes no difference" to the story (ibid.). Similarly, when a character is kidnapped, "for kidnappers it is important to transport their victim to another country - but which particular country again makes no difference at all" (ibid.). The idea that a story can take place anywhere is further undermined by Bakhtin's claims that different genres, literary periods, and even the oeuvre of individual writers are characterised by different chronotopes. In a similar vein, Bal claims that different types of actions necessitate different settings; for example, declarations of love typically take place "by moonlight on a balcony, high-flown reveries on a mountain-top, a rendezvous at an inn, ghostly appearances among ruins, brawls in cafes" (2017[1985]: 130). Moretti proposes an analogous argument in connection to genre, claiming that "each space [has] its own genre: defined by a spatial distribution - by a map - which is unique to it" (1998[1997]: 35, original emphasis). Thus, science fiction requires technologically advanced environments and/or far-away planets and galaxies, the Robinsonade a deserted island, and the pastoral idyllic natural landscapes.

Following the same line of argumentation, Leane's analysis of the different subgenres of the thriller makes two important claims: first, the author points out that the "apparent interchangeability of the settings should not be confused with their irrelevance" (2016: 26). In other words, even if it does seem that the action could easily be transplanted into a different environment without affecting the plot, that does not mean that space itself is an insignificant narrative element. Second, she challenges the idea of "anywhere" settings by pointing out that while the novels in her corpus of thrillers can "theoretically be set anywhere, there are some locations that facilitate $[. .$.$] genre conventions and others that frustrate them" (ibid.). Each$ subgenre of the thriller therefore shows a distinct preference for a certain type of environment, such as domestic spaces (psychological thriller), the metropolis (political and legal thrillers), or remote natural settings such as jungles (eco-thrillers; ibid.).

A similar case can be made for the (traditional) fairy tale: while the lack of specificity regarding its spatial and temporal framework may suggest that it can take place anywhere, there are spaces the readers, drawing on their genre schemata, are likely to anticipate, such as forests or vaguely medieval castles, and those they are likely to dismiss as being incompatible with the genre, such as distant planets or 
spaceships, modern cities, highways filled with speeding automobiles, television studios, or factories - to name but a few (contemporary fairy tales and fairy-tale revisions break away from this convention, often choosing contemporary, urban settings). In addition to readers' previous experience with the genre and existing genre schemata, the anticipated settings are largely influenced by the physical and cultural geography of the narrating community, a notion that finds its expression in concepts such as the ecotype, which Carl Wilhelm von Sydow (1948; 1948[1934]) defines as a local variant of an international tale type, or Lauri Honko's theory of the milieu-morphological adaptation of folklore, which highlights the links between oral narratives and traditions on the one hand, and locations "in the experienced physical milieu" on the other (2013[1981]: 174). Although traditional fairy tales rarely include references to real-world geography, they are inevitably influenced by the physical environments in which they are created and shared. Lindahl, for instance, notes that transplanting a particular tale type from one socio-cultural and geographical context to another is bound to affect its narrative landscape: thus, if European fairy tales, "set in a feudal world of castles, kings, and princesses", are transported to, for instance, the Appalachian Mountains, the castles will be replaced "with farmhouses and kings with rich farmers" (2018: 16).

To paraphrase Nodelman, the idea that the fairy tale can take place anywhere, therefore, does not really mean anywhere at all (Nodelman \& Reimer 2003[1992]: 255). ${ }^{85}$ Even within a given fairy-tale narrative, the different actions cannot (and do not) take place anywhere; rather, specific types of actions (and, by extension, fairytale plots) demand specific settings. For example, a quest or adventure fairy tale will take its protagonists across large distances and into the magical domain, while a fairy tale built around the $\mathrm{M} \rightarrow \mathrm{N}$ transference will typically remain within the confines of the non-magical domestic space. Encounters with the magical helper commonly take place in open, natural spaces such as a forest, wilderness, or open road, which is why it is crucial for the protagonist to leave home. Weddings can only be celebrated in royal castles, so fairy tales that do not feature a (royal) wedding, such as "Hansel and Gretel" or "The Fisherman and His Wife", do not end at court. Fairy tales about romantic partners typically include the space of the bedroom: enchanted bridegrooms shed their animal skins only in the intimate space of the marital bedroom ("Hans My Hedgehog", "The Donkey"); forgotten brides or fiancées also

Nodelman makes a similar observation about the types of actions that can occur in the fairy tale. Although it seems that in a world filled with magic absolutely anything can happen, Nodelman points out that there are some limitations to this: for instance, pumpkins may be turned into coaches and animals may be able to talk, but "the talking pigs don't turn into pumpkins" (Nodelman \& Reimer 2003[1992]: 255). Therefore, he concludes, "the settings of fairy tales aren't places in which anything at all can happen" (ibid., emphasis added). 
reveal their true identities and remind their oblivious partners of everything they had done for them within or in front of the bedroom ("The True Bride", "The Singing, Springing Lark"). While animal bridegrooms can only reveal their true nature within the closed and intimate space of the bedroom, persecuted characters of royal origin reveal their true identity only in open spaces of nature. The king's son in "Iron Hans" reveals his golden hair, both a marker of his royal status (the princess recognises this, claiming that she "already knew from his golden hair that he wasn't a gardener's helper"; Grimm 2003[1857]: 448) and his connection to the magical, in the garden. Similarly, the princess forced to tend geese in "The Goose Girl" lets her golden hair down only when she finds herself outside the palace and in the field, while the youngest princess in "The Goose Girl at the Spring" discards her mask in the forest, at the spring. One exception to this rule is found in "All Fur", which sees the princess shed her animal disguise within the confines of a small chamber under the stairs of the royal palace.

The supposed interchangeability of spaces also applies only to a certain degree. According to Lüthi (1986[1947]) - and other scholars, such as Likhachev (2014[1967]) - individual spaces exist only in terms of their usefulness to the plot and in relation to the protagonist: once they leave a given space behind, it simply disappears and is never mentioned again. Seen from that perspective, the significance of space stems primarily from its function: much like the helpers, donors, and other figures listed in Propp's Morphology (1968[1928]) whose identity is secondary to the role they perform in the story (giving advice, bestowing gifts, etc.), the identity and traits of individual narrative spaces seem ancillary to their function (the place where the protagonist is tested, receives magical assistance, etc.). Moreover, if the concrete identity is secondary to the function of space, then the concrete spaces filling a particular slot in the story are completely interchangeable and the story could take place anywhere. However, like the notion of anywhere settings, the interchangeability of spaces also has its limits. On the one hand, it is easy to imagine that, for example, the encounter between the discharged soldier and the devil in "Bearskin" could be transplanted from the wilderness to a forest, with the outcome of the encounter staying the same. On the other hand, there are some conditions a given space needs to meet in order to fill a particular slot in the story. For example, in fairy tales featuring the $\mathrm{N} \rightarrow \mathrm{M}$ transference, the encounter between the magical and the non-magical typically takes place in an open, natural, non-human environment. Going back to the example of "Bearskin", this means that while the wilderness might theoretically be substituted by a forest, it could not be replaced by a village or the protagonist's home. An important factor in this respect is the fact that major acts of spatial transference - i.e. those that signify shifts between individual episodes - are transitions "between qualitatively different spaces" (Dan 1977: 15). In other words, the space into which the protagonists move is in some way 
juxtaposed with the one they are leaving: if one is non-magical, the other is magical; if one is threatening, the other is safe, etc. Therefore, while it might seem that the concrete identity of individual spaces through which the characters move is altogether irrelevant, there are certain limitations related to the individual narrative slots the spaces fill, meaning that not every space can fill every narrative function.

The discussion of the supposedly pan-geographic nature of space in fairy tales also brings to mind Likhachev's claims about the boundless, limitless nature of fairytale space, which can be expanded and converted to extreme limits (2014[1967]: 329-330). The boundlessness of the fairy tale stems from the fact that there are no obstacles to how far the protagonist can go, as the environment in itself poses no obstacle. However, as with the pan-geographic quality of anywhere settings, there are some limits to the supposedly limitless nature of fairy-tale space, dictated largely by genre conventions as well as the cultural and geographical background of the specific corpus of tales. For example, the protagonists of the Grimms' (or other European) fairy tales will not be found roaming around a jungle or desert, or making their way through frozen landscapes. The said boundlessness, which seems more linked to the protagonist's movements than narrative space, is therefore confined within the boundaries of the fairy-tale world, which is delineated by the aforementioned conventions and cultural and geographical influences: within that limited world, the protagonists' movements are boundless and can take them as high as heaven or as far as the end of the world.

\section{Ambiguous and transmutable}

Even though, as the previous chapter demonstrated, certain adjectives are more likely to be attributed to certain spaces than others (e.g. the forest is frequently described as large or dark), the qualities of individual fairy-tale spaces are not fixed. Rather, they change from narrative to narrative, or even within the same narrative (cf. Bal 2017[1985]: 127). To quote Lutwack, individual spaces "are neither good nor bad in themselves but in the values attached to them" by a specific narrative (1984: 35). For example, a fairy-tale forest can have both positive and negative connotations, depending on its role in a given story, the identity of its inhabitants, and the types of activities it provides the setting for. On the one hand, it is a dark and threatening "place of oppression" populated by malevolent figures such as cannibalistic witches ("Hansel and Gretel") or robbers ("Strong Hans"); on the other hand, it is "the place to avoid or punish oppression", providing shelter for persecuted characters who run away from abusive households ("Brother and Sister", "Snow White"; Maitland 2012: 272). This ambiguity - although not explicitly described as such - is also recognised by Sale (1978), who, also using the example of the forest, contends that in and of themselves, individual fairy-tale spaces are devoid of meaning and only 
acquire it within individual stories. What the forest means in a given fairy tale, he writes, "will be what is made of it in this telling of this tale. By itself the wood is nothing; combined with other things it can direct a tale, be a place where princes never live but often visit, where woodcutters can be found, and wolves, and witches" (Sale 1978: 30; emphasis added). While ambiguity has already been identified as an important feature of fairy-tale space, most notable by Haase (2000: 363-366), the concrete manifestations of this ambivalence have not been explored in greater detail. The present section therefore proposes to examine the ambiguous nature of fairy-tale spaces and the different ways in which it is manifested in the KHM narratives.

Although some spaces in the Grimms' collection may be predominantly portrayed in a positive or negative light, no space has exclusively positive or negative connotations. The space of home, which is (especially in children's literature) typically associated with safety, familiarity, and belonging (cf. Alston 2008; Dewan 2004; Nodelman 2008), can also be depicted as a source of threat and abuse from which the protagonist must flee (Alston 2008: 69, 75). With its implications of possible misfortune, separation, and loss of freedom (cf. Gerndt 1997), the sea in the KHM fairy tales frequently has negative connotations, featuring as a source of danger and site of treason. Danger appears in the form of monstrous creatures such as giants and giant birds ("Faithful Ferdinand and Unfaithful Ferdinand"), jealous brothers ("The Water of Life"), or duplicitous spouses ("The Three Snake Leaves"). The Princess of the Golden Roof is kidnapped at sea ("Faithful Johannes"), while merchant ships that set sail rarely return, spelling financial ruin for their owners ("The King of the Golden Mountain"). On the other hand, the sea can also provide magical assistance for disadvantaged characters, as evidenced by the Grimms' "The Fisherman and His Wife" and "The Golden Children" (cf. Karlinger 1984). Another predominantly sinister fairy-tale space is the inn, which typically serves as a site of deception ("The Magic Table, the Golden Donkey, and the Club in the Sack"), theft ("The Golden Goose", "The Devil's Sooty Brother"), and even violence (Kawan 2012: 836). On the other hand, it is also a space of social gathering, where people come together, establish relationships, and receive assistance (ibid.: 834-835; see also Grzywka 2018). This is the case in "Bearskin" and "Faithful Ferdinand and Unfaithful Ferdinand", where acquaintances made at inns help characters overcome their financial troubles. Even hell, which might be expected to be portrayed in an exclusively negative fashion, takes on positive traits in the majority of the KHM tales: in "The Devil With the Three Golden Hairs" and "The Griffin", it provides the protagonist with magical assistance, while in "The Devil's Sooty Brother", it serves as a platform for righting social wrongs.

In some cases, the same space can demonstrate different, contrasting attributes. In "The Old Woman in the Forest" (KHM 123, ATU 442), for instance, the heroine is both endangered and protected within the space of the forest: first she is attacked 
by robbers, but later finds shelter within a magic tree. When a given space is portrayed as inherently ambiguous (i.e. the different traits exist simultaneously and are not the result of spatial transformation), its opposing traits are typically relegated to its different parts. The periphery (in "The Old Woman in the Forest", the edge of the forest) is usually portrayed as safer, probably because of its vicinity to human settlements, while the more distant and less familiar centre is typically populated by various malicious figures who pose a threat to the protagonist. This type of spatial distribution of qualities is also featured in (among other tales) "Hansel and Gretel", where the forest edge belongs to the non-magical, familiar domain (from there, the eponymous siblings can still find their way home), while the deep, unfamiliar centre where the gingerbread house is located, belongs to the magical domain. In "Strong Hans", the differences between the safe forest edge and its perilous centre are highlighted through differences in physical appearance and colour palate: the familiar, safe areas where the mother gathers fir branches are green and bright, full of birds and "many-hued flowers" (Grimm 2003[1857]: 493). As soon as the mother and son move away from the forest edge, they are captured by robbers and taken through "shrubs and brier bushes", "deep into the black forest, where nobody had ever gone in the course of a year" (ibid.).

In addition to demonstrating opposing traits, individual spaces are also transmutable, meaning that they may undergo physical and/or symbolic transformations which bring about changes in their initial traits. Physical transformations of space are often realised through magical means, used to alter its size, appearance, and material status (see Chapter 5). For instance, in "The Poor Miller's Apprentice and the Cat", "The Iron Stove", "The Golden Children", and "The Goose Girl at the Spring", small, modest or outright poor cottages are turned into large, luxurious castles, typically as a reward for the protagonists' services. "The Fisherman and His Wife" depicts a series of magical transformations of space, from impoverished hovel to a precious church, each one larger, richer, and more luxurious than the previous.

Symbolic transformations of space (i.e. non-physical changes in their qualities) are typically brought about by introducing or eliminating individual characters into or from a given space. The familiar, safe domestic space can "become defamiliarized and threatening" (Haase 2000: 364) through the introduction of an evil stepmother, as evidenced by (among other tales) "Cinderella" or "Snow White". The physical environment of the protagonist in this newly transformed domestic space also changes as they are often forced to occupy only certain parts of the house (Cinderella's banishment into the kitchen is perhaps the most vivid and well-known example). Being so drastically different from its previous, original version, this "new" household takes on the attributes of both threat and unfamiliarity. Conversely, the elimination of a threatening figure (e.g. the stepmother in "Hansel and Gretel" or 
"The Juniper Tree") can turn an abusive space into a pleasant one. The ending of "Hansel and Gretel" combines a symbolic transformation of space with an implication of a physical one. The parental home in the story is initially set up as: a) a threatening space (given the presence of the evil stepmother), and b) a space of lack and deprivation. However, by the end of the story both designations are drastically altered: the stepmother's demise signifies the elimination of threat, which, in turn, results in the symbolic transformation of home into a safe space of family idyll. The second transformation is suggested rather than explicitly shown in the narrative, as the riches Hansel and Gretel find in the witch's house will presumably enable them to turn their ramshackle cottage (a poverty- and hunger-stricken environment) into a space of abundance and material security. The transformed home is thus doubly secured, both in the material (financial) and the emotional sense.

In the case of enchanted, especially haunted, spaces in which juxtaposed attributes such as safe/threatening or non-magical/magical are merged (cf. Messerli 2019: 27), the elimination of characters also leads to a shift in their position on the non-magical-magical divide. As Camilla Asplund Ingemark points out, enchanted spaces - i.e. originally non-magical spaces which are placed under a (temporary) spell or curse - in which the magical and the non-magical are "fused into one" are essentially multispatial (2006: 10). Their disenchantment, which typically entails the destruction of antagonistic magical creatures such as demonic cats and dogs, ghosts ("A Tale About the Boy Who Went Forth to Learn What Fear Was"), mysterious black men ("The King of the Golden Mountain"), or devils ("The Prince Who Feared Nothing"), therefore brings about a shift in the spatial domain, from the magical to the non-magical. The fact that the magical inhabitants of these spaces are typically malicious also means that the disenchantment transforms the threatening space into a safe one. For instance, the dangerous forest from which no one returns in "Iron Hans" becomes safe after the terrifying wild man is captured and put into a cage. Similarly, the spell placed on the forest in "The Two Brothers" is broken after the titular siblings defeat the evil witch and throw her into the fire. As the witch is destroyed, the dark, dangerous forest is instantly transformed: "After she had been burned, the forest opened up all by itself and became bright and clear, so that one could see the royal castle" (Grimm 2003[1957]: 226). As the quotation demonstrates, symbolic transformations of space are often coupled with physical ones.

If spaces have no fixed attributes, it may be assumed (following the argumentation presented in the previous chapter) that they derive them from the traits of their inhabitants, demonstrated by their actions. Likhachev notes as much when he points out that in itself space never provides obstacles for the protagonist's progress. Rather, any hindrance is typically the result of the antagonist's involvement. Thus, for example, "[t]he sea does not hinder seafarers in itself. Only when the hero's opponent interferes does a storm arise" (Likhachev 2014[1967]: 
328). The actions of characters therefore serve to characterise a particular space, i.e. to lend traits to a space that in itself is neither positive nor negative. The fact that both symbolic and physical transformations of space discussed above are linked to characters further supports this notion. However, despite the important role of characters in establishing narrative spaces and their qualities, space is not an entirely passive and dependent component of this process that simply assimilates the traits of its inhabitants. Rather, it also actively "reacts" to characters, displaying different traits and assuming different roles in response to them. This is especially prominent in stories featuring the test of merit, which some characters will inevitably fail and others pass with flying colours; consequently, the same space will demonstrate positive traits in relation to some characters and negative traits in relation to others. For example, in ATU 480 tales, such as the Grimms" "Mother Holle" or "Saint Joseph in the Forest", the same space is supportive and beneficial for the "kind" girl, whose positive traits are rewarded, but becomes a source of punishment for her "unkind" counterpart. Although these responses may be seen as an extension of the actions of the tester figure who metes out rewards or punishments, the different - for lack of a better word - behaviour of space is elicited in response to protagonists and antagonists in general, independently of tests and tester figures. Thus, a space which figures as the site of assistance and support for the protagonist can easily become a source of threat or even the site of the antagonist's demise. In "Brother and Sister", for instance, the forest provides shelter and protection for the titular pair; however, when their evil stepsister is taken to the forest, she is torn apart by wild boars. In "The Two Travelers", the good tailor has his vision restored under the gallows, while the evil shoemaker is blinded on the same spot.

The transmutable nature of space, which is not always a reflection of its inhabitants' character and behaviour, points to its complexity and dynamic nature (explored in more detail in the following section). Its active response to characters, rather than a simple mirroring of their traits, suggests that space creates its own changing identity through a continuous, dynamic interplay with characters. As such, it is "always unfinished and open" (Massey 2005: 141), rather than fixed and unchanging, as views of space as a passive container might suggest. Consequently, it is created through and dependent on various interactions and interrelations with characters, events, and other spaces (ibid.: 66,68 ), which points to its dynamic as well as relational nature. The following section examines this notion of interdependence and the active role of space in more detail by considering its relationship with those who inhabit or move through it. 


\section{Dynamic and relational}

Building and expanding on the observations about the spatial qualities discussed above, this section argues that fairy-tale space is active, dynamic, and relational in nature. It views space as an unfixed, mutable element that is continuously being recreated through an interplay of relations within the narrative (between individual spaces and characters, events, objects, and other spaces) as well as between the narrative and reader (see Chapter 3). Furthermore, it argues that the intra-narrative relationships are bidirectional, meaning that not only do various narrative elements - especially characters - shape narrative space, but are also influenced by it. As such, the present discussion challenges the traditional view of (fairy-tale) space as a passive background for events and a container of characters and objects, which neither interacts with its contents nor exists independently of them (Lüthi 1986[1947]; Leeuwen 2007). To examine how the dynamic and relational quality of space is realised in the fairy tale, this section focuses primarily on the relationship between space and the characters who inhabit or move through it.

The dynamic and relational nature of space is abundantly highlighted in research associated with the spatial turn. Juxtaposed with the "fixed, asocial, and timeless" absolute space, relational space ${ }^{86}$ is defined as being socially produced, "as fluid, mutable, and ever changing" (Warf 2010: 2403) ${ }^{87}$ In a text often seen as one of the precursors of the spatial turn, Michel Foucault states that "[w]e do not live in a kind of void, inside of which we could place individuals or things", but "inside a set of relations that delineates sites which are irreducible to one another and absolutely not superimposable on one another" (1986[1984]: 23, emphasis added). Space itself, therefore, takes "the form of relations among sites" (ibid.). The same idea is proposed by Henri Lefebvre, who writes that space "is not a thing, but a set of relations between things, objects and products" (1991[1974]: 83, emphasis added). The different aspects of relational space have been extensively explored by (among others) Doreen Massey (1999a; 1999b; 2005), who describes it as a "product of interrelations; as constituted through interactions" (2005: 9), a sphere of possible multiplicity which is never closed or fixed but always changing and unfinished (1999a: 27-28).

The traditional view of space as a container suggests its lack of interaction with the characters and events it contains; however, as the previous discussion of different spatial qualities has demonstrated, space in fairy tales both influences and is

86 The term "relational space" is sometimes used synonymously with "relative space" (cf. Warf 2010), although some scholars make a clear distinction between the two (cf. Harvey 1994; 2004).

87 For a more philosophically intoned discussion of the concepts of relational space and space as a container, see Johansson (2004[1989]: 145-60). 
influenced by its "contents". In the course of the fairy-tale narrative, space is in a constant state of flux, changing both physically and qualitatively. The ambiguous and transmutable nature of space means that individual spaces do not have fixed, unchanging attributes and meanings; rather, the attributes and meanings they take on in individual stories or even in the course of the same story, are (re)produced through their relations with characters, events, and other spaces. A given space can therefore become threatening or protective, depending on its relationship to a particular character (providing shelter or hiding a threat). Since the precise position of individual spaces within the wider spatial network is not clearly established (the discontinuous, unmappable quality of fairy-tale space), the identity of spaces often emerges from their interrelationships: the immense distance of a far-away magical space is established as such in relation to the starting point of the protagonist's journey. In other words, a given location is not distant in itself, but distant from another location. By bringing these disconnected locations together, the act of spatial transference becomes an act of spatial production, a spatial practice - to borrow a term from Lefebvre (1991[1974]: 38). ${ }^{88}$ These interrelationships extend beyond the narrative itself to include the reader, who, through the processes of gap filling and creating mental maps, actively participates in the process of producing space (see Chapter 3). The unlocalised setting of the fairy tale is therefore defined in relation to the here and now of the reader.

Characters are particularly important participants in spatial relations. They do not simply move through and act against a spatial background; rather, by means of their spatial transference and other actions, they engage with and influence space, and are, in turn, influenced by it. The following sections examine the interrelationship between narrative space and characters, focusing on the way in which spatial transference results in or is triggered by character transformation.

\section{Interrelationship between space and characters}

As the overview of literature presented in Chapter 2 demonstrates, fairy-tale space has rarely been studied as a narrative element in its own right; rather, many have argued that, given the central importance of the protagonist to the fairy tale, "[o]bjects and nature never occur in the fairytale for their own sake" (Lüthi 1987[1975]: 14) but only in relation to the characters. In other words, narrative

88 Lefebvre's tripartite division of space encompasses spatial practice (physical and material practices in society), representations of space (space as conceptualised by urbanists, scientists, planners, etc.), and spaces of representation (imagined, passively experienced space; 1991[1974]: 38-39) - the "perceived - conceived - lived triad" (ibid.: 40). 
elements such as space only exist (and can subsequently only be studied) through their relationship to characters. While the presence of space depends on the characters, the characters themselves exist in isolation from their environment, with which they fail to create bonds (ibid.: 42-43). Their relationship can therefore be understood in terms of a container and its content, or a background and foreground: there is no real interaction between the two, as the former serves merely to frame and/or highlight the latter. For Lüthi, this lack of interaction is necessary because it allows the protagonists to easily detach themselves from their existing environment and "effortlessly [enter] into fruitful contact with distant worlds, with worlds above and below, with nature and with individual figures of our world" (ibid.: 138). Although he does not cite Lüthi as a source, Leeuwen (2007) reaches a similar conclusion regarding the lack of bonds and ease with which the protagonists can (and must) leave their environment. This research challenges such views on two accounts: first, it claims that space, while closely connected with characters, does not exclusively rely on them, and is instead also (re)created through relationships with objects, events, and other spaces; second, characters and space do engage in a bidirectional relationship, in which characters influence space and are, in turn, influenced by them.

Following the traditional character-centred view of space, one might be inclined to conclude that the non-magical or magical and other qualities of individual fairytale spaces derive exclusively from the qualities and actions of the characters that inhabit them. This is true to some extent: we know that the pond in "The Nixie in the Pond" is a dangerous magical space because the nixie lives there; similarly, the magical quality of the dark areas of large forests is indicated by the nature of its inhabitants (witches, giants, etc.). However, this is only part of the story, as the qualities of a given space can also be established independently from characters, for example, via its inherent physical properties, contents (objects), and positioning within the larger spatial network of the story (i.e. relationship to other spaces). The magical quality of a space can therefore be indicated through its distance and/or inaccessibility: it can be far away or hidden, so that human characters cannot find it without magical assistance (see Chapter 5); it might be underground ("The Three Feathers"; "The Gnome", KHM 91, ATU 301), hidden within the depths of a large forest ("Hansel and Gretel"), or in a place that can only be reached with a magical object ("The Crystal Ball"), magical assistance ("The Golden Bird", "The Glass Coffin"), or guidance (e.g. receiving instructions on how to get there in a dream in "The Nixie in the Pond"). Furthermore, as Chapter 5 argues, the magical quality of magical spaces is often indicated by their physical appearance and appellatives, such as the castle of the golden sun ("The Crystal Ball") or the glass mountain ("The Drummer", "The Raven"). Moreover, the presence of precious materials such as gold or silver, or diamonds ("The Worn-out Dancing Shoes") and jewels ("The Lettuce 
Donkey"), also bespeaks the magical qualities of certain spaces. Thus, the domains and the non-magical or magical spaces they encompass do not exist exclusively in relation to characters and events, nor do they exclusively derive their specific qualities from them. In that sense, it might be argued that they are not solely dependent on characters.

Chapter 5 discussed the role of characters as bearers of implicit space-related information, which is deduced primarily on the basis of their social status and position on the non-magical-magical divide. However, this relationship works both ways: in other words, not only can the traits of the characters reveal important information about the spaces they inhabit, but space can also tell us much about its inhabitants (Jong 2012a: 16). For instance, describing a forest (or parts of the forest) as dark signals that its inhabitants are likely to be nefarious and bent on harming the protagonist. In other words, the spaces characters occupy tell us something about them even before the characters themselves are introduced: for example, the extraordinary building material used to construct the forest cottage in "Hansel and Gretel" suggests that its occupant is no ordinary human being. Moreover, the inclusion or exclusion of characters from a given space can also serve to establish their identity: thus, as Meletinskij notes, the villain is often characterised as being "foreign", i.e. belonging to a different space from the protagonist (Meletinskij et al. 1974[1971]: 120, n.19). Even the characters' physical positioning within a given space may reveal something about them, with Cinderella's place at the hearth, among the ashes, or All Fur's tiny room beneath the stairs signalling their marginal position within their respective households, as well as their low social status as manual laborers.

As previous sections of this chapter argue, different types of actions demand different types of settings. Substituting the traditional character- and plot-centric view with a space-centric one, we can argue that individual spaces accommodate certain types of action while hindering or even rejecting others (Lotman 1977[1970]: 281). In other words, some things are more likely to happen in the castle or in the woods than others. It can be expected that the encounter between the magical and the non-magical will take place in the forest or a similar open, natural space such as the sea or wilderness, while the private bedroom is likely to be the setting for romantic encounters or the revelation of secrets.

Moreover, the argument that certain spaces welcome or are more susceptible to certain actions over others can be expanded even further to include characters as well; thus, different spaces also require different characters. In other words, not every character belongs to every space: on the more general and encompassing level of the domain, non-magical characters belong to the non-magical domain, while magical characters belong to the magical domain. In the case of human characters, their inclusion in a particular space typically depends on their social and material status: 
simply put, kings belong in palaces, farmers in humble cottages. Furthermore, as the following discussion will demonstrate, changes in characters' social status and identity ${ }^{89}$ in general typically create an incongruity between space and its denizen, who is now symbolically out of place (Baak 1983: 93-94). This newly created incompatibility with their environment forces characters to leave the space they are currently occupying and move to a space that is more suitable to their new identity.

\section{Space and identity transformation}

Fairy tales are ostensibly about transformation (Short 2015: 50): frogs are violently changed into princes, ramshackle cottages wondrously become castles and stately mansions, poor peasants turn into kings, proverbial rags are converted into riches. At the centre of all these transformations and the fairy tale in general are the protagonists, who, while in the midst of numerous metamorphoses, remain curiously unchanged. Throughout their incredible journeys they do not change as characters (in the sense of psychological and emotional development and growth) nor do they acquire any new knowledge or experience (Lüthi sees this as a reflection of the genre's isolating tendencies; 1986[1947]). However, while the main characters seem unaltered by the events they participate in, their material circumstances (and environments) are in a constant state of flux. Even though they do not acquire anything in terms of knowledge or experience (a result of the fairy-tale characters' lack of depth), their narrative journey includes a series of material gains and losses, changes of appearance, etc. Protagonists therefore do change by the end of the story, but only because their appearance has been altered, and/or because something has been added to their possessions and, by extension, their social status (Leeuwen 2007: 41).

Of particular note for the present research is the fact that all these changes in characters' identities coincide with instances of spatial transference, meaning that as the protagonist moves into a new environment, he or she typically takes on a new identity. The importance of spatial transference for character development has been the subject of extensive research. Katharine Young notes that movements through space and boundary-crossing instigate changes in the protagonist (1987: 188-189), while Eugene Timpe interprets the different narrative spaces the protagonists move through as symbolic representations of the different stages in their development (1971: 189). Research produced within psychoanalytic, feminist, queer/trans, and

While the term "identity" may seem somewhat inappropriate to a discussion on characters predominantly defined in terms of their social and familial roles, who have little depth and complexity, it will nevertheless be retained given the lack of a more suitable alternative. 
disability scholarship places special emphasis on protagonists leaving home and moving into natural and/or magical spaces, which is interpreted as the starting point for their maturation, self-realisation, liberation, etc. (see Chapter 2). Leeuwen's (2007) research on space, character identity, and transformation is especially extensive. Because of the close link between spatial transference, and identity exploration and transformation, he writes, departing from home and setting off on a journey signifies not only leaving behind one's physical and social environment, but also one's identity. By leaving home, Leeuwen claims, the protagonist becomes "an 'unknown' person, on which no specific identity is inscribed, except that of the traveller, the stranger and the "other"' (2007: 15). As they leave their old identity behind, protagonists open themselves up to new roles and identities, determined by the spaces they move through. While providing interesting and important insights, existing research on the topic remains primarily character-oriented, which means that the spatial component of the process of identity transformation is overlooked or reduced to its symbolic or metaphorical meanings. For Leeuwen, for instance, a given space is significant only as part of a "sequence of the hero's life" and transformation (ibid.: 74). The present research assumes a different approach by, firstly, focusing on space, and, secondly, examining space as an active component of the processes of identity negotiation and transformation. Moreover, it proposes that the relationship between character identity and space is an active, bidirectional one. Thus, the fact that certain types of space are compatible with certain types of characters suggests that changes in a character's identity necessitate a change of space, initiating spatial transference; on the other hand, spatial transference can also serve as a stimulus for identity change as characters typically take on new identities following their transference into a new environment. Spatial transference therefore leads to identity change (when characters leave a given space, they also leave a particular identity behind) or is motivated by it (changes in protagonists' identities make them incompatible with their current environment, prompting them to leave it).

To examine the relationship between space and character identity in more detail, this section will examine two of the Grimms' fairy tales: "All Fur" and the previously discussed "The Virgin Mary's Child”. "All Fur", a story about a young princess who dons a cloak made of animal fur to escape her father's incestuous desire, demonstrates how a radical change in a character's environment can trigger identity change, which, in turn, triggers spatial transference (see Figure 5.). Opening at court, the story identifies the protagonist through her royal lineage and relationship with her parents: she is the daughter of the king (later the object of his romantic advances), who bears an uncanny resemblance to her deceased mother. The parental link is highlighted on the linguistic level, as the heroine is continuously referred to as "the king's daughter" (die Königstochter; Grimm 2003[1857]: 240) in the first part of the 
story. However, the initially safe and idyllic parental home is transformed into a threatening, dangerous space when the king declares his intention to marry his own daughter. ${ }^{90}$ The heroine's new, highly undesirable status as the object of her father's incestuous desire prompts her to reject her royal identity and assume a new one that of the titular All Fur. She discards her old identity and dons a new one by concealing her beautiful golden hair and substituting her royal garments (outward markers of royal identity) with "a cloak made up of a thousand kinds of pelts and furs" (ibid.: 239).

By rejecting royal garments (markers of her social, as well as feminine and human status) and embracing a cloak made of animal fur (symbol of nature), the heroine alters her identity (Scott 1996: 155) and irreversibly severs all existing bonds: with her parental home, her social role, and her parents (hiding the hair she "inherited" from her mother and abandoning the house of her father). ${ }^{91}$ However, her newly acquired identity as a child of nature of sorts, embodied in the gown which comes from nature, makes her incompatible with the domestic (human) royal setting, which means she must leave it in search of a more appropriate environment. As a liminal, "transitional space [...] somewhere between the patriarchal spaces of the father and husband" (Muhawi 2001: 272), the forest appears to be especially well suited to the heroine's new, hybrid identity, produced at the intersection of the human and the non-human. The new fur outfit also becomes the source of a proper name (All Fur) given to the previously anonymous king's daughter. However, as Nicolaisen points out, this "name which replaces namelessness [...] takes account only of her nasty outward appearances", thus confirming the loss of her (royal, feminine, human) status in the eyes of the world (1993: 66). This loss is reflected on the linguistic level as the narrative now refers to her as a "beast" (ein Wild), a "strange animal" (ein wunderliches Thier), "All Fur" (Allerleirauh), and a "furry creature" (Rauhtierchen; Grimm 2003[1857]: 240). In addition to concealing her true identity by blackening her face, covering her hair, and wearing animal skins, the

90 In the few KHM tales that depict the father as a source of danger for the protagonist (a role typically assumed by stepmothers or mothers), the Grimms' editorial changes work towards alleviating the circumstances of his transgression and shifting at least part of the blame onto someone else (e.g. "The Maiden Without Hands" introduces the character of the devil for this purpose; cf. Dundes 1987). "All Fur" shifts a significant portion of the blame onto the mother, who makes the king promise to marry a woman whose beauty matches her own (the only person who fits this description is their daughter). Part of the responsibility is also transferred onto the king's counsellors, who urge him to remarry (he himself is so overcome by grief that he does not consider taking a second wife), reminding him of his duty to the kingdom.

91 The heroine seems highly aware of the importance of clothes as outward markers of identity, and cleverly uses them to first rebuff her father's sexual advances (the fur cloak) and later attract a royal suitor (magnificent sun, moon, and star dresses). 
heroine uses language to the same end. When asked by the king's hunters to identify herself, she replies she is a poor child (ein armes Kind) without a mother or father. Not only does the use of the noun "child" - in German the neuter Kind - allow her to hide her age, sex, and gender (Yocom 2012: 107), but her self-identification as an orphan (when she was initially defined exclusively through her relationship with her parents) serves as a symbolic disowning, an additional severing of ties with her "old" identity and embracing of a new one. Once it is revealed that the strange creature is actually human - and as such incompatible with the non-human space of nature the hunters decide to take it with them to the castle, as the forest is no place for a human child (even one dressed in animal fur). The change of setting prompts yet another identity change as the "strange animal" becomes first a kitchen maid (in the small chamber under the stair), ${ }^{92}$ a mysterious guest at the ball (in an upstairs room of the castle), and finally, after she reveals her royal identity by letting her hair down and donning beautiful dresses, the "dear bride" (Grimm 2003[1857]: 242) of the king.

92 Daniela Perco believes that situating the heroine in the kitchen where she has to tend the fire and prepare food (for her future husband, no less) marks her reintegration from nature (the forest) into "culture", while also enabling her to use her (traditionally feminine) skills to capture the king's attention (1993: 79). 

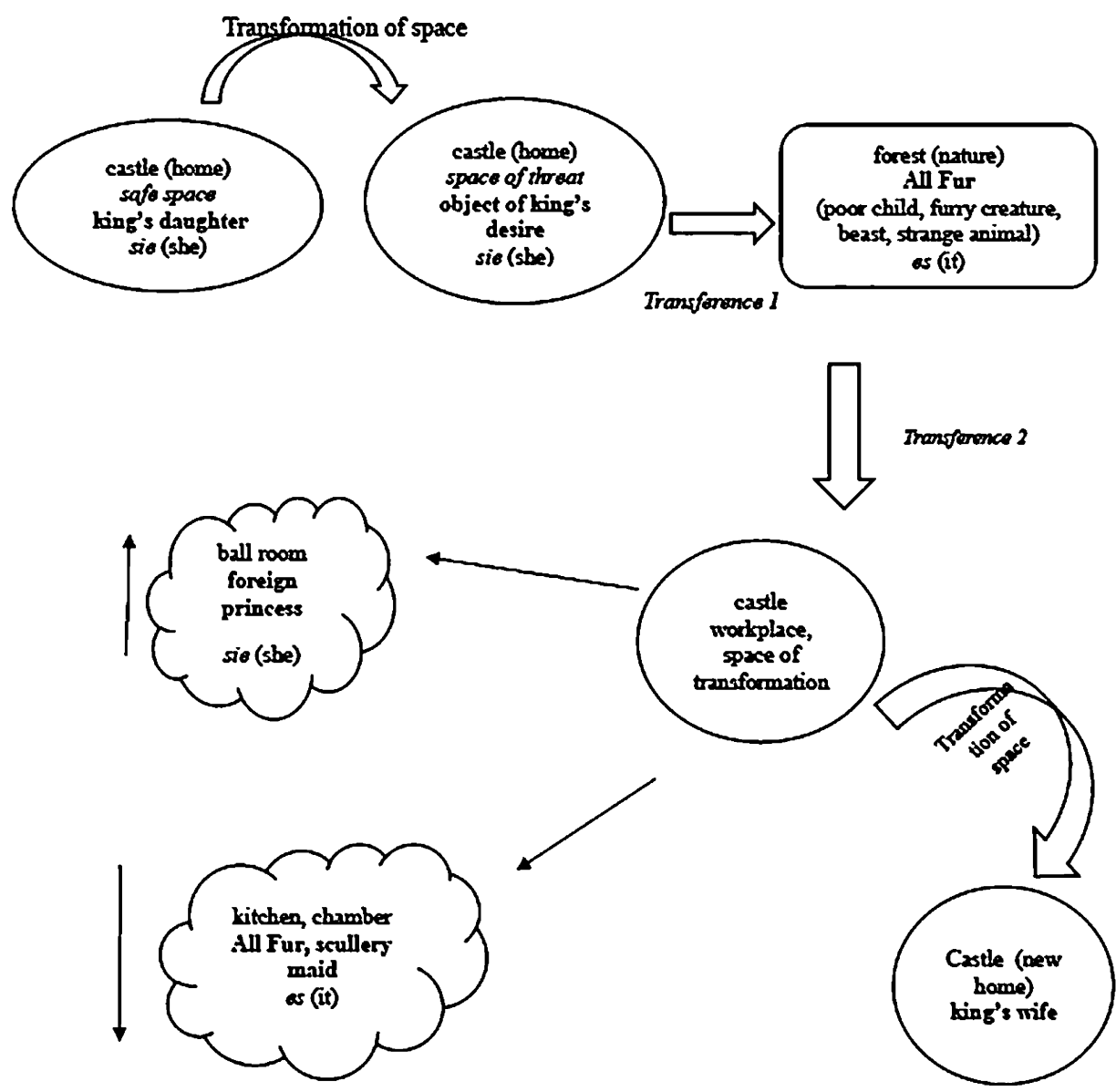

Figure 5. Spatial transference and identity transformations in "All Fur" (Source: the author).

As previously stated, the story of the Virgin Mary's child unfolds as a series of spatial transferences of the heroine, each of which brings about alterations of her identity, indicated through language - i.e. references to the heroine (see Figure 6.) and clothing, which, according to Do Rozario, is frequently used to (de)construct the identity of fairy-tale characters (2018: 3). At the same time, her actions lead to changes in her identity, which, in turn, bring about spatial transference. Like the protagonist of "All Fur", the young heroine is initially identified through relationship to her parents, i.e. as the only child (ein einziges Kind) of a poor woodcutter and his wife. As she leaves the parental home and is taken to heaven, the girl also leaves behind her identity as the woodcutter's daughter (the parents are not mentioned again) and becomes the eponymous Marienkind - the Virgin Mary's child. In fact, Mary explicitly identifies herself as the heroine's surrogate parent: "I'll take her with me and be her mother and look after her" (Grimm 2003[1857]: 7). 


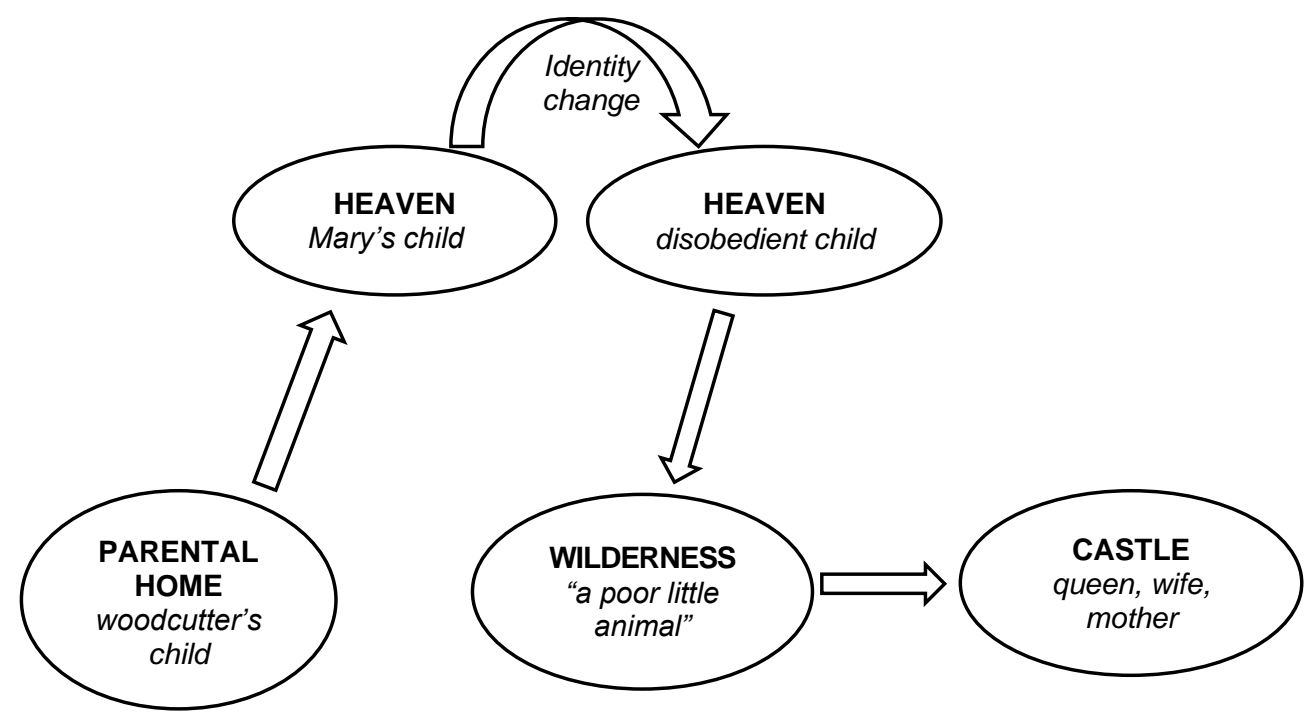

Figure 6. Spatial transference and identity transformations in "The Virgin Mary's Child" (Based on Kujundžić 2014: 230).

The following instance of spatial transference is prompted by a change in the heroine's identity, which is the result of her disobedience and transgression, and their subsequent denial. By opening the forbidden chamber and lying about it, the girl betrays Mary's trust, thus losing the protection of her magical benefactress as well as her identity as Mary's child. This new identity of disobedient child is incompatible with her current environment, leading to her expulsion from heaven: "Then the Virgin Mary said: 'You've disobeyed me, and you've even lied. You're no longer worthy enough to stay in heaven"' (Grimm 2003[1857]: 8). What follows is both a literal and metaphorical fall from grace as the heroine is brought back to earth and confined to a barren wilderness. In this "desolate spot" (ibid.: 9), the former Mary's child gradually turns into a child of nature: she finds shelter inside a hollow tree and survives on roots and berries. Devoid of both human company and human language (she is now mute), and exposed to the elements, she is gradually stripped of her golden garments and left naked (in her "natural state"). To further underscore her newly assumed identity, the story refers to her as "a poor little animal" (ein armes Thierchen; ibid.). ${ }^{93}$ The final act of spatial transference occurs when she is discovered by a king and taken to his castle. Once there, the (woodcutter's/Mary's/nature) child becomes a woman - wife to the king and mother

93 Both the vocabulary and imagery used in this scene (a solitary female sleeping in a hollow tree) are reminiscent of the forest scene in "All Fur". For a discussion on the link between female characters, nature, and isolation, see Bottigheimer (1987). 
to his children. The two domestic spaces that frame the story - the woodcutter's cottage (the home of the father) and the royal palace (the home of the husband) - can be interpreted as metaphors for the heroine's social rise from poor woodcutter's daughter to queen.

As the examples of the two tales analysed here show, identity changes connected with individual spaces are communicated in various ways. A new environment typically provides a new role for the mobile character, and introduces new linguistic means of their identification, or even an entirely new physical appearance, all of which become the basis for the character's new identity. The identity change can take the form of physical transformations (e.g. humans turning into animals and vice versa) or simple changes of clothing. Since, as Carole Scott argues, clothes in fairy tales function as "the outer expression of an inner identity", a change of attire may be interpreted as an indicator of a character's identity transformation (1996: 151). In fairy tales, clothes and those who wear them "are one" (Horn 1977: 98), which means that by putting on a new outfit, a given character is also "putting on" a new identity. Fairy tales, in which everything is taken at face value, interpret this correlation quite literally, so that a character wearing a different set of clothes is perceived by those around them as an entirely different person (cf. Muhawi 2001: 279). Cinderella thus goes unrecognised by her stepsisters when she replaces her usual rags with a ball gown. Even in the case of physical - typically animal - transformations, the animal skin donned by the transformed characters is often treated as a disguise of sorts, a garment which they can slip on and off, until their partners throw it into the fire, thus freeing them from their enchantments (e.g. in "Hans My Hedgehog", "The Donkey", or "The Three Feathers"; Scott 1996: 152).

Challenging traditional views about the status of space as an inactive background against which characters' identity transformations take place, the present research argues that spatial transference is both a prerequisite for and a result of identity transformation. In fairy tales, social mobility - i.e. the transformation of characters' social identities - is predicated on magical intervention, which, in turn, is predicated on spatial transference (the protagonist must leave home to encounter the magical). Physical and social movement in fairy tales are therefore doubly intertwined: on the one hand, movement across different spaces symbolises mobility along the social ladder, as the character assumes different (social) identities in each new space; on the other hand, spatial transference is a direct prerequisite for social mobility. ${ }^{94}$

Different settings typically signify different identities for fairy-tale protagonists, the nature of which is expressed linguistically, as well as externalised through

94 Bakhtin identifies the same link in his analysis of the Bildungsroman, which shows protagonists being simultaneously shifted through space and "up and down the rungs of the social ladder" (2010[1986]: 20). 
references to various material objects, most notably clothing. Viewed from this perspective, space can, as Thomas (1986) suggests, be seen as part of the process of externalisation, i.e. a means of conveying on the material plane what is taking place on the internal (psychological, mental, emotional) plane. As Lüthi (1986[1947]) argues, since fairy-tale characters lack an inner life, the changes and developments one would expect on the psychological and emotional level are substituted with changes on the external, material (and, as this research maintains, particularly spatial) plane. A fairy-tale character who is initially good will not undergo a psychological transformation that will turn him evil, but a peasant may become a king since this transformation requires only external alterations such as the acquisition of wealth and - most prominently for the present discussion - a change of setting (moving from a poor cottage to a royal palace). In other words, while the fairy-tale protagonist may not change as a person (after all, he or she has no personality to speak of), their social identity may be significantly altered and improved through the acquisition of wealth and/or marriage to a partner of higher social standing. The most notable and drastic change often occurs at the very end of the story, which typically sees protagonists ascend to the very top of the social ladder - regardless of whether they are simply regaining their initial position or drastically altering their original social standing (cf. Bottigheimer 2009) - by becoming king or queen or at least next in line for the throne. This newly acquired identity is complemented by a new domestic space, which typically stands in stark contrast to the initial one (cottage vs. castle). Even in stories that depict a circular journey, the point of return is not identical to the point of departure. Thus, the parental home is transformed by returning protagonists, who have changed since their departure from home and brought back material goods. This is the case, for instance, with "Hansel and Gretel", in which the titular siblings return home with riches found at the witch's cottage, which enable the transformation of the poverty-stricken cottage into a space of material security and abundance.

Within existing research, considerable attention has been dedicated to pronominal and other alterations as means of establishing character identity (among others, Muhawi 2001; Robinson 2007, 2010; Yocom 2012), as well its material most notably sartorial (Ivleva 2009; Scott 1996) - extensions, while the spatial component of these transformations remains largely overlooked. Yocom (2012), for instance, provides a comprehensive analysis of the language in "All Fur", tracing the changes in the references used to designate the heroine at different points in the story. However, while she does recognise the heroine's spatial transference as a mirror of her symbolic journey "among bodily locations: between human and animal, as well as among man, woman, thing, or a bodily state that combines all of the above" (2012: 92-93), she does not explore the relationship between change of space and change of identity in more detail. Even Leeuwen's research, centred on the link between 
spatial transference and the development and transformations of the mobile character's identity (2007: 23), remains largely character-centric. As a result, the author never recognises spaces as meaningful in their own right, but only through "their function as the object of journeys, or their relation to the situation of the heroes" (ibid.). In contrast, the present research argues that while fairy-tale characters are an important means of establishing narrative space, space does not simply mirror the traits of the characters who move through or inhabit them; rather, they simultaneously shape and are shaped by them. The fact that a change in space and/or character typically leads to spatial transference, as the character seeks an environment that is more suitable to their new identity, suggests that space is not simply a mirror of the character or background for their actions and transformations. Rather, it actively shapes those transformations, participates in bidirectional relations, and is continuously (re)created and (re)transformed through them. 


\section{Conclusion}

The main goal of this doctoral thesis was to examine narrative space and spatial transference in the fairy tales published in the final, seventh edition of Jacob and Wilhelm Grimm's Children's and Household Tales. By focusing on a heretofore largely overlooked narrative element, the thesis has argued for its significance and challenged a number of traditional views of space in the fairy tale, primarily its status as a container for characters and events, and an inactive, insignificant background against which events unfold and which exists simply because the story has to take place somewhere. Such a view may be the result of several factors: the long-standing privileging of time over space across the humanities and social sciences, which was reflected in literary studies and narratology; the seeming disinterest of the fairy-tale genre in space, a view supported by what has traditionally been described as the dearth of spatial information and unspecified setting. The recognition of the importance of space brought on by the spatial turn has only recently translated into more systematic research efforts within narratology and other narrative-based disciplines, including fairy-tale studies. It is to the conversation within these disciplines that the present thesis hopes to contribute.

Unlike much within existing studies, this research has viewed fairy-tale space as a narrative element that should be examined its own right, rather than a symbolic representation of something else that should be studied for what it can tell us about the characters or plot. In its five chapters - bookended by an introduction and conclusion - the thesis has examined three aspects of the narrative space of the fairy tale: its structure, presentation (meaning, the narrative and linguistic means of its realisation), and qualities. In addition to exploring the different aspects of space within fairy-tale narratives, it has also asked whether any of these spatial aspects can also be viewed as specific to the fairy-tale genre. To that end, the research has been expanded to include genres other than fairy tales featured in the Grimms' collection: animal tales, didactic tales, aetiological tales, folk tales, formula tales, humorous (Schwank) tales, legends, and religious tales. The two main research questions of this theses can therefore be summed up as: what do fairy tales tell us about narrative space and what does narrative space tell us about fairy tales? 
The research was based on the corpus of 215 generically diverse tales included in the final, seventh edition (1857) of the Grimms' collection. Based on a working, primarily content-based, definition of the individual short prose narrative genres featured in the KHM, the corpus was divided into the primary corpus, consisting of 96 texts identified as fairy tales, and the secondary corpus, encompassing genres other than fairy tales (Appendix 1). This preliminary categorisation was revised in the course of the research, as individual genre categories were re-examined through the lens of narrative space and spatial transference. Taking space, and especially the division of space into different domains, into account as a possible genre criterion has led to a redrawing of the boundaries of individual genre categories and even a redefining of the categories of the didactic tale, Schwank tale, and aetiology as modes (sub-types of other genres) rather than independent genres (Appendix 2).

Theoretically and methodologically, the research has primarily drawn on fairytale studies and narratology. Using fairy-tale scholarship as its theoretical framework, it has reviewed, systematised, and built on existing observations on fairy-tale space (and the fairy tale in general), which have been complemented with a narratological perspective. Narratological explorations of space, which have (to this author's knowledge) mostly overlooked the fairy tale, have provided a model for the present examination of the structure and representation of space in the Grimms' narratives. The research conducted on the corpus of the KHM narratives has been text-oriented and has utilised a textual narratological analysis.

The Introduction to this thesis presented the main research questions, defined the key terms of the research - fairy tales, narrative space, and spatial transference - and described the research corpus. It also presented the research methods and provided an outline of the thesis. Chapter 2 has demonstrated that, while considerably underresearched, narrative space has not been entirely absent from fairy-tale scholarship. The chapter identified three major trends within existing scholarship: studies that dismiss space as an abstract background for events or completely overlook it; studies in which space is a secondary concern within discussions on other aspects of the genre; and studies in which space is the primary research focus. An examination of existing literature - especially writings on space produced within the frameworks of dominant twentieth- and twenty-first-century approaches to fairy-tale scholarship has shown that space has rarely been studied in its own right, as an independent narrative element of the fairy tale. Rather, it has commonly been examined in purely symbolic terms, as a stand-in for something else and embodiment of the main themes identified by a particular interpretation. This is especially true of the non-magicalmagical divide, which is often equated with binaries such as the conscioussubconscious (psychoanalytic approaches), male-female (feminist approaches), or normative-non-normative (queer/trans and disability studies). Spatial transference is consequently also seen as a crossing of symbolic rather than physical boundaries, a 
metaphorical journey of maturation (psychoanalytic approaches) or self-realisation (queer/trans and disability studies). In addition to examinations of its symbolic and interpretative potential, space has been viewed in terms of its function as an organisation principle (formal approaches) or in connection to various extra-literary elements, for which space serves either as a more or less literal corresponding element (real-life geography) or symbolic reference (socio-historical approaches). The present research has challenged such symbolic interpretations of space, which reinforce its status as a narrative element which is virtually insignificant in itself, as its value only stems from what it can reveal about the meaning of the story, other narrative elements such as structure, or various extra-literary elements. The final part of the chapter identified a gap within existing research, and outlined the theoretical and methodological framework of the thesis, highlighting its main research questions and contribution to fairy-tale scholarship.

Chapter 3 used narratological tools to examine the structure of fairy-tale space specifically, its individual components and means of their organisation into categories of varying scopes. By applying Ryan's five-part model (narrative frame, setting, story space, storyworld, narrative universe) to the fairy tale, it demonstrated the complexity and multi-layeredness of both fairy-tale space and the process of its construction. The latter proved to be the result of constant communication and renegotiation between text and reader, in which narrative space is continuously recreated with the disclosure of each new piece of information. Such complexity of space and the dynamic nature of its (re)construction challenge the traditional view of space as something that exists only in connection with the plot or characters. On the contrary, as the application of Ryan's model to the fairy tale has demonstrated, the spatial extension of the text goes beyond what is explicitly identified. The chapter has also attempted to overcome some limitations of Ryan's model, which primarily stem from its applicability to different narratives regardless of genre. To adapt the model to the study of the spatial structure of the fairy tale, the present research has expanded it with the addition of a new category, the domain or realm, which encompasses spaces which are governed by a specific set of natural laws. By highlighting the specificities of individual genres in this way, the research aims to contribute to narratology, as well as fairy-tale scholarship.

Examining (KHM) genres through the lens of the domain helped resolve several genre-related issues. Firstly, using space (specifically, the domain) as a criterion for genre classification suggests the Schwank tale (Chapter 3), the didactic tale, and the aetiological tale (Chapter 4), categories of narratives whose status as independent genres has been contested in existing scholarship, could be seen as modes rather than genres. Thus, they are not characterised by a stable number of domains or unique spatial structure, adopting instead the underlying structures of the genres they are assimilated to (e.g. religious Schwank, animal aetiology, etc.). Secondly, the 
existence of two domains - the non-magical and the magical - sets the fairy tale apart from genres with only one domain, such as the animal or folk tale. However, since other genres such as the legend or religious tale also encompass two antithetical domains, this research has argued that distinguishing features of the fairy tale are found not in the existence of the two domains but in the spatial parameters and interaction between them, as well as the specific means of crossing the boundary that separates them. All of this points to the heretofore largely overlooked potential of narrative space as a possible criterion for genre classification and definition.

For its examination of the potentially genre-specific features of fairy-tale space, Chapter 3 took as its starting point Lüthi's comparison of the fairy tale and legend. While acknowledging the frequency with which the non-magical and magical are separated by large distances, this thesis has argued that the key spatial parameter for delineating the two domains and their relationship is clearly delineated separation, rather than remoteness. In other words, the two domains of the fairy tale are always clearly delineated and separated by a boundary which must be crossed in order for the meeting between the magical and the non-magical - which this research considers to be one of the defining features of the genre - to take place. Chapter 4 discussed the interaction between the two domains, as well as the means of crossing the interdomain boundary in more detail. It identified three main features of interdomain boundary-crossing in the fairy tale: 1) even though (the Grimms') fairy tales mostly focus on the transference of the human protagonist into the magical domain, the boundary can be crossed from both sides; 2) boundary-crossing is always temporary, meaning that by the end of the story, the mobile character must return to his or her "native" domain; 3) the interaction between the non-magical and the magical, as well as the boundary-crossing, are predicated on a series of special requirements. While the requirements differ for non-magical and magical characters, their common denominator is establishing initial contact with a character who is native to the target domain and, by admitting the mobile character into the target domain, acts as the gatekeeper. Non-magical characters seeking entry into the magical domain must prove they are worthy of magical assistance (test of merit) or familiar with certain automatic rules the story operates under. Vulnerable (lost, abused, or otherwise mistreated) characters typically earn magical assistance through their vulnerability. Finally, non-magical characters may be lured by the magical, which needs their assistance or wants to help or harm them. To this end, the magical uses objects, animals, and visual or audio signals. Magical characters enter the nonmagical either to help (benevolent magical) or harm (malicious magical) the nonmagical. The malicious magical either forces entry into the non-magical or manipulates non-magical characters into granting it access. The benevolent magical must be (unwittingly) summoned by the non-magical character in need, who has various types of verbal and non-verbal summons at their disposal, including explicit 
invitations and permissions, marital vows, (reckless) wishes, verbal formulae (spells), cries for help, crying, negative thoughts, giving up, and other expressions, gestures, and behaviour indicating desperation. To determine whether the aforementioned traits of interdomain boundary-crossing in the fairy tale are also unique to the genre, Chapter 4 examined the means of interdomain boundarycrossing in other dyadic KHM genres: the legend and the religious tale, as well as their Schwank sub-types. Those genres mostly focus on the transference of supernatural or sacred characters, who typically move into the human domain at will, without meeting any special requirements. Boundary-crossing on the part of human characters is typically permanent and predicated on certain conditions: in religious tales, human characters can enter the sacred celestial domain only if they have led a just and pious life, and only after they have passed away; the human characters in legends may also have to die in order to enter the supernatural domain and/or establish contact with a character who is endemic to it.

Chapter 5 examined the direct and indirect narrative and linguistic strategies the fairy tale uses to convey spatial information. Specifically, it discussed naming, direct description (direct strategies), descriptised narration, and references to characters and objects or materials (indirect strategies). The discussion of characters as a means of spatial representation focused on their identity, especially social status, which may be used to infer the wider space they inhabit, and their actions, especially spatial transference which serves to expand the spatial parameters of the story. It also examined how characters' perception and experience influence spatial representation, as well as their ability to construe space through their verbal and cognitive processes (dreaming). Objects and materials were discussed as important means of establishing the dominant traits of a particular space, such as its (non)magical, threatening, or supportive quality. The chapter also explored the different strategies used to establish the dimensions of individual spaces and relationships (especially proximity or distance) between them. The latter include creating an itinerary, references to magical transportation objects, using concrete units of measurement, temporal expressions, repetition, and audio-visual signals.

Based on the analysis of the different strategies of spatial representation, Chapter 5 brought into question the oft-cited claim about the dearth of spatial information in fairy tales, which is commonly ascribed to the genre's focus on action and stylistic parsimony, i.e. the tendency of the fairy tale to avoid any type of "additional" information that does not immediately propel the plot forward, such as descriptions. While maintaining the focus on action, the fairy tale does not neglect its spatial extension, which is mostly established through brief, selective descriptors and the less frequently used descriptive passages. Such direct strategies bring space to the forefront, making it (albeit briefly) the narrative focus. While direct descriptions are primarily functional, meaning that the spatial traits and aspects that are highlighted 
are those of immediate importance to the plot, indirect strategies reveal that the presence and role of space is not exhausted in its usefulness to the plot. Rather than exclude spatial information altogether, the fairy tale's style and narrative focus dictate the type and extent of spatial information that will be conveyed, as well as the means of its communication.

Generally speaking, indirect strategies and brief descriptions (typically manifested as one or two premodifier adjectives or short postmodifier phrases) are reserved for non-magical spaces, while magical spaces are commonly accorded more attention. This suggests that the narrative relies more on readers to draw on their own experience to fill in the gaps in connection with the non-magical domain. Simply put, the story does not have to spend a lot of time describing "ordinary" environments such as villages or forests which the protagonist, as well as the implied audience, is (presumably) familiar with through first-hand experience. In contrast, the magical domain presents a departure from both the readers' and characters' experience and is therefore typically established more clearly. The same principle applies to the objects used in the two domains: non-magical items are usually identified in more general terms and rarely described, while their magical counterparts tend to be established as more specific and are described in more detail. A prominent place among both non-magical and magical spaces belongs to castles and palaces (often created by magic), which are accorded more attention. Chapter 5 proposed several possible explanations for this: firstly, since the typical rags-to-riches trajectory regularly includes the transference from an impoverished into a regal space, a detailed description of the new, luxurious environment highlights the significance and extent of the protagonist's social climb. Secondly, building on the argument that magical spaces are accorded more attention because they are empirically distant from the protagonist and audience, as well as Röhrich's claims about the roots of the fairy tale being among the lower classes, the chapter argued that regal spaces are similarly inaccessible and unfamiliar to the protagonist and audience, and therefore need to be more explicitly and comprehensively established. As embodiments of the happilyever-after ideal, regal spaces represent something both the protagonists and audiences dream about and associate with the highest values.

Through its examination of the key qualities of fairy-tale space - its abstract, unlocalised, discontinuous, ambiguous, and transmutable nature - Chapter 6 challenged the traditional view of fairy-tale space as a container for characters, objects, and events, which does not interact with its "content" in any way. Instead, the chapter argued, space is a dynamic narrative element, created through a set of interrelations between characters, objects, events, and other spaces. Characters and other participants in these relations not only influence space but are also, in turn, influenced by it. The chapter examined the bidirectional nature of these relations in more detail by focusing on the link between characters and space, specifically the 
changes in the mobile character's identity which either follow or prompt their transference into a new environment. As a product of relations that is not fixed but continues to change throughout the story, fairy-tale space is seen as relational. The chapter also re-examined the notion that, given its unspecified setting, which seems to imply nowhere in particular, the fairy tale can take place virtually anywhere. Thus, the notion of the boundless, pan-geographic nature of the genre's setting is limited by genre conventions, as well as the cultural and geographical framework of a given fairy-tale corpus.

Based on the observations presented in this thesis, space emerges as a complex narrative element which exists in different forms and on different narrative levels (physical, emotional, alternative, mental, imaginary), can be established in different ways, and is created through a dynamic process which involves the collaboration of both different narrative elements and different participants in the process of literary communication. The interaction between space and other narrative elements means that its study can also enhance our understanding of those elements (characters, objects, events). Perhaps most importantly, a consideration of narrative space can shed new light on our understanding of the different short prose narrative genres. Not only does it call for a reconsideration of existing genre categories and their status as independent genres, but it also opens up new avenues of thinking about the unique features of individual genres. Given the absence of a clear consensus on the definition of the fairy tale outlined in the Introduction, expanding existing attempts at defining the genre to include more complex spatial issues might lead to the development of a more comprehensive description of the fairy tale. While additional research into other dyadic genres is necessary to validate the conclusions about the genre-specific nature of fairy-tale space and its organisation, this thesis proposes a preliminary, space-based definition of the fairy tale as a (short) prose narrative genre which depicts two clearly delineated and separated domains, the non-magical and the magical. The interaction between the non-magical and the magical, which must occur in the course of the story, is dependent on spatial transference, most notably the crossing of the interdomain boundary. In the fairy tale, both magical and nonmagical characters can cross the boundary and enter the opposite domain; however, that crossing is always temporary and predicated on certain conditions.

However, it should be noted that the findings presented in this thesis are based on a limited and culturally, historically, linguistically, and stylistically specific corpus of nineteenth-century German fairy tales. While the ultimate aim of the thesis is to provide an analytical framework that can be used for analysing fairy tales (and other short prose narrative genres) outside the KHM, its applicability to other corpora remains to be determined by future research.

With its focus on narrative space and spatial transference in fairy tales, the present thesis aims to contribute to existing scholarship on fairy tales as well as 
narratology. Its contribution to fairy-tale scholarship consists of focusing on an aspect of the genre that has so far been accorded little (systematic) attention and using it to shed more light on other narrative elements (especially characters) as well as the genre as a whole. The thesis also aims to contribute to narratology, which has produced a significant portion of research on space in literature and other types of media, as it modifies its analytical models which are applicable to the study of narratives across genres to better suit genre-specific research. By comparing the fairy tale to other short prose narrative genres featured in the KHM, the thesis provides an impetus for research on space in short prose narrative genres (both literary and folklore genres), which has so far not been explored in greater detail. In literary studies, the focus is still mainly on longer narrative forms such as the novel, while folklore studies have so far shown more interest in place narratives, space of the narrative (rather than narrative space), and the relationship between literary and extra-literary space.

As previously noted, considering spatial issues enhances our understanding of both the individual fairy-tale elements and the genre as a whole. The study of space seems all the more significant in the current proliferation of fairy-tale retellings, adaptations, and other types of reimaginings, which often foreground and explicitly address spatial issues. Based on the premise that all fairy tales exist within the same, shared narrative universe, fairy-tale pastiches or "mashups" in particular are concerned with negotiating spatial boundaries. Mashups such as films from the animated Shrek franchise, Michael Buckley's Sister Grimms series of novels (20052012), or Bill Willingham's comic book series Fables (2002-2015) (to name but a few) often challenge the audience's genre schemata by placing familiar characters in contemporary, urban environments (e.g. modern-day New York in Fables), or injecting the traditional fairy-tale settings with knowing references to contemporary popular culture (the Shrek franchise is especially known for its pop culture proficiency). However, the prominence of space in such narratives goes beyond the simple substitution of the abstract setting of the traditional fairy tale with a specific (often contemporary) temporal and geographical setting.

While it may seem that the merging of different stories and characters into a single narrative might erase the spatial parameters of the traditional fairy tale, many contemporary mashups actually replicate the spatial structure of the traditional fairy tale described in this thesis, the preservation of which often serves as the basis of the story. For example, the story of the first Shrek movie (2001) is set in motion by the villain's banishment of magical characters from the Lordship of Duloc (the nonmagical domain) into the green ogre's swamp (the magical domain). Spatial transference is also at the centre (and title) of Steven Sondheim's (music and lyrics) and James Lapine's (book) musical Into the Woods (1986), which follows several well-known fairy-tale characters such as Cinderella and Little Red Riding Hood as 
they move into the unknown forest, where they are allowed to explore their desires and wishes, and the realities of the seemingly idyllic "happily ever after". By placing its characters into a kind of archetypal fairy-tale environment - the titular woods being perhaps the most prototypical locus of the traditional fairy tale - Into the Woods uses the genre's recognisable features (most notably the departure from home and entrance into the magical domain) to challenge its ideological underpinnings.

In contrast to Sondheim's and Lapine's musical, which remains rooted in traditional fairy-tale geography, other fairy-tale mashups such as The Sisters Grimm or Fables situate familiar characters within contemporary environments. While the fairy-tale characters find themselves situated within decidedly non-fairy-tale environments and surrounded by "ordinary" people, the narratives nevertheless find ways to re-establish the traditional domain structure and interdomain boundary. Thus, although they now reside in the midst of the human domain, the fairy-tale characters still find themselves within a circumscribed space (Fabletown and Farm in Willingham's comic books or Ferryport Landing in Buckley's series), where they exist separately and secretly from human beings. The distinction between fairy-tale characters and humans is often further reinforced by using special terms to designate them; for example, Buckley's fairy-tale characters call themselves Everafters, while Willingham's refer to humans as Mundys. As in Shrek, the inciting incident in both Willingham's and Buckley's work is an act of spatial transference: specifically, a kind of re-enactment of the plight of the Pilgrims in which fairy-tale characters arrive in the USA in an attempt to escape persecution. Fabletown is established after the magical domain known as the Homelands is conquered by the mysterious Adversary, while the Everafters flee the hostility they face in Europe by sailing across the Atlantic and establishing a new city on the bank of the Hudson River. In both examples, the starting point for the fairy-tale characters' journey in some way evokes the pseudo-medieval setting of traditional (Western) fairy tales: in The Sisters Grimm, it is literally pre-modern Europe, while in Fables, it is an imaginary environment which echoes medieval Europe through its weaponry and social system. This stands in stark contrast with the modern world they inhabit in the present day, to which they adapt by wearing modern clothes, taking on jobs, etc.

Whether it is foregrounded as in many contemporary retellings and mashups, or seemingly overlooked, space is a significant narrative element with genre-defining potential. Considering space therefore promotes our knowledge of the fairy tale and opens avenues to develop more comprehensive definitions of the genre. As such, it enhances our understanding of not only the fairy tale's past iterations but also its current and future developments. 


\section{References}

Aarne, Antti. 1910. Verzeichnis der Märchentypen. FF Communications 3. Helsinki: Academia Scientarium Fennica.

Abbott, H. Porter. 2008[2002]. The Cambridge Introduction to Narrative. 2nd edn. Cambridge: Cambridge University Press.

Abrams, Meyer Howard. 1999[1957]. A Glossary of Literary Terms. 7th edn. Boston: Heinle \& Heinle. Alston, Ann. 2008. The Family in English Children's Literature. New York \& London: Routledge.

Andrew, Joe. 2007. Narrative, Space and Gender in Russian Fiction. 1846-1903. Amsterdam: Rodopi. Apo, Satu. 1980. "The Structural Schemes of a Repertoire of Fairy Tales. A Structural Analysis of Marina Takalo's Fairy Tales Using Propp's Model”. In Lauri Honko and Vilmos Voigt (eds.), Genres, Structure and Reproduction in Oral Literature. Budapest: Akadémiai Kiadó, pp. 147-158.

-. 1995. The Narrative World of Finnish Fairy Tales: Structure, Agency, and Evaluation in Southwest Finnish Folktales. FF Communications 256. Helsinki: Academia Scientarium Fennica.

Ashliman, D. L. 2017. “Grimms’ Fairy Tales in English”. Available at: http://pitt.edu/ dash/grimmengl.html.

Auerbach, Erich. 2003[1946]. Mimesis: The Representation of Reality in Western Literature. Trans. Willard R. Trask. Princeton: Princeton University Press.

Baak, Jan Joost van. 1983. The Place of Space in Narration: A Semiotic Approach to the Problem of Literary Space, with an Analysis of the Role of Space in I. E. Babel's Konarmija. Amsterdam: Rodopi.

Bacchilega, Cristina. 1997. Postmodern Fairy Tales. Gender and Narrative Strategies. Philadelphia: University of Pennsylvania Press.

- 2007a. Legendary Hawai' $i$ and the Politics of Place. Tradition, Translation, and Tourism. Philadelphia: University of Pennsylvania Press.

-. 2007b. "Review of Fairy Godfather: Straparola, Venice and the Fairy Tale Tradition by Ruth B. Bottigheimer". Western Folklore 66(3/4), pp. 383-386.

- 2013. Fairy Tales Transformed? Twenty-First-Century Adaptations and the Politics of Wonder. Detroit: Wayne State University Press.

Bachelard, Gaston. 1994[1957]. The Poetics of Space. Trans. Maria Jolas. Boston: Beacon Press.

Bachmann-Medick, Doris. 2016[2015]. Cultural Turns. New Orientations in the Study of Culture. Trans. Adam Blauhut. Berlin \& Boston: Walter de Gruyter.

Bakhtin, Mikhail M. 2010[1986]. "The Bildungsroman and its Significance in the History of Realism (Toward a Historical Typology of the Novel)". Trans. Vern W. McGee. In Caryl Emerson and Michael Holquist (eds.), Speech Genres and Other Late Essays. 12th edn. Austin: University of Texas Press, pp. 10-59.

- 2011[1937]. "Forms of Time and of the Chronotope in the Novel". Trans. Carly Emerson and Michael Holquist. In Michael Holquist (ed.), The Dialogic Imagination. Four Essays. Austin: University of Texas Press, pp. 84-258.

Bal, Mieke. 2017[1985]. Narratology. Introduction to the Theory of Narrative. 4th edn. Toronto, Buffalo, London: University of Toronto Press. 
Balzamo, Elena. 2004. "Die ätiologische Erzählung”. Fabula 45(1/2), pp. 93-101. https://doi.org/10.1515/fabl.2004.012.

Barchers, Suzanne I. 1990. "Preface”. In Suzanne I. Barchers (ed.), Wise Women. Folk and Fairy Tales from around the World. Englewood: Libraries Unlimited, Inc., pp. xi-xii.

Barthes, Roland. 1975[1966]. "An Introduction to the Structural Analysis of Narrative". Trans. Lionel Duisit. New Literary History 6(2), pp. 237-272. https://doi.org/10.2307/468419.

Bascom, William. 1965. "The Forms of Folklore: Prose Narratives". The Journal of American Folklore 78(307), pp. 3-20. https://doi.org/10.2307/538099.

Baumgart, Wolfgang. 1936. Der Wald in der Deutschen Dicthung. Berlin \& Leipzig: Walter de Gruyter.

Beebee, Thomas O. 1994. The Ideology of Genre. A Comparative Study of Generic Instability. University Park: Pennsylvania State University Press.

Bemong, Nele, Pieter Borghart, Michel De Dobbeleer, Kristoffel Demoen, Koen De Temmerman, and Bart Keunen (eds.). 2010. Bakhtin's Theory of the Literary Chronotope: Reflections, Applications, Perspectives. Gent: Academia Press.

Ben-Amos, Dan. 2010. "Straparola: The Revolution that was Not". Journal of American Folklore 123(490), pp. 426-446. https://doi.org/10.1353/jaf.2010.0000.

Benson, Stephen (ed.). 2008. Contemporary Fiction and the Fairy Tale. Detroit: Wayne State University Press.

Bettelheim, Bruno. 1991[1976]. The Uses of Enchantment. The Meaning and Importance of Fairy Tales. London: Penguin Books.

Bies, Werner. 2009. "Tiermärchen". In Kurt Ranke (ed.), Enzyklopädie des Märchens. Band 13, Lieferung 2. Berlin \& New York: Walter de Gruyter, pp. 624-627.

Biggs, Thomas and Jessica Blum (eds.). 2019. The Epic Journey in Greek and Roman Literature. Cambridge: Cambridge University Press.

Black, Jeremy. 2003[1992]. The British Abroad. The Grand Tour in the Eighteenth Century. Stroud: Sutton Publishing.

Bošković-Stulli, Maja. 1963. "Narodne pripovijetke". In Maja Bošković-Stulli (ed.), Pet stoljeća hrvatske književnosti. Sv. 26. Narodne pripovijetke. Zagreb: Matica hrvatska, Zora, pp. 7-29.

- 1967. Narodna predaja o vladarevoj tajni. Zagreb: Institut za narodnu umjetnost.

—. 1975[1968]. "Narodna predaja - Volkssage: kamen spoticanja u podjeli vrsta usmene proze". U Maja Bošković-Stulli, Usmena književnost kao umjetnost riječi. Zagreb: Mladost, pp. 121-136.

—. 2006[1997]. Priče i pričanje. Stoljeća usmene hrvatske proze. 2nd edn. Zagreb: Matica hrvatska.. 2012[1982]. "Bajka". Libri \& Liberi 1(2), pp. 279-292.Bottigheimer, Ruth. 1987. Grimms' Bad Girls and Bold Boys. The Moral and Social Vision of the Tales. New Haven \& London: Yale University Press. - . 1988. "From Gold to Guilt: The Forces which Reshaped Grimms' Tales". In James McGlathery (ed.), The Brothers Grimm and the Folktale. Urbana \& Chicago: University of Illinois Press, pp. 192-204.

-. 2002. Fairy Godfather. Straparola, Venice, and the Fairy Tale Tradition. Philadelphia: University of Pennsylvania Press.

-. 2009. Fairy Tales. A New History. Albany: State University of New York Press.

-. 2014. Magic Tales and Fairy Tale Magic. From Ancient Egypt to the Italian Renaissance. Basingstoke: Palgrave Macmillan.

Boyd, Carloyn E. 1996. "Shamanic Journeys into the Otherworld of the Archaic Chichimec". Latin American Antiquity 7(2), pp. 152-164. https://doi.org/10.2307/971615.

Bragg, Tom. 2016. Space and Narrative in the Nineteenth-Century British Historical Novel. New York: Routledge.Brémond, Claude. 1970. "Morphology of the French folktale". Semiotica 2(3), pp. 247276. https://doi.org/10.1515/semi.1970.2.3.247.

Briggs, Charles L. 1993. "Metadiscursive Practices and Scholarly Authority in Folkloristics". The Journal of American Folklore 106(422), pp. 387-434. https://doi.org/10.2307/541905.Briggs, Katharine. 1978. The Vanishing People. Fairy Lore and Legends. New York: Pantheon Books. 
- 2002[1970]. British Folk-Tales and Legends. A Sampler. London \& New York: Routledge.Brković, Ivana. 2013. "Književni prostori u svjetlu prostornog obrata”. Umjetnost riječi 57(1-2), pp. 115-138.

Broadwell, Peter M., and Timothy R. Tangherlini. 2016. "WitchHunter: Tools for the Geo-Semantic Exploration of a Danish Folklore Corpus". The Journal of American Folklore 129(511), pp. 1442. https://doi.org/10.5406/jamerfolk.129.511.0014.

Brückner, Annemarie. 1990. "Himmel”. In Kurt Ranke (ed.), Enzyklopädie des Märchens. Band 6, Lieferung 4/5. Berlin \& New York: Walter de Gruyter, pp. 1036-1047.

Buchholz, Sabine, and Manfred Jahn. 2005. "Space in Narrative". In: David Herman, Manfred Jahn, and Marie-Laure Ryan (eds.), Routledge Encyclopedia of Narrative Theory. London: Routledge, pp. 551-555.

Buckley, Michael. 2005-2012. The Sisters Grimm (The Fairy-tale Detectives, The Unusual Suspects, The Problem Child, Once upon a Crime, Magic and Other Misdemeanors, Tales from the Hood, The Everafter War, The Inside Story, The Council of Mirrors). New York: Amulet Books.

Canepa, Nancy. 1999. From Court to Forest. Giambattista Basile's Lo cunto de li cunti and the Birth of the Literary Fairy Tale. Detroit: Wayne State University Press.

Carey, John. 1987. "Time, Space and the Otherworld". Proceedings of the Harvard Celtic Colloquium 7, pp. 1-27.

Casey, Edward S. 1997. The Fate of Place. A Philosophical History. Berkeley, Los Angeles, \& London: University of California Press.

Certeau, Michel de. 1988[1980]. The Practice of Everyday Life. Trans. Steven Rendall. Berkeley, Los Angeles, \& London: University of California Press.

Chatman, Seymour. 1978. Story and Discourse. Narrative Structure in Fiction and Film. Ithaca \& London: Cornell University Press.

Christiansen, Reidar Thoralf. 1992. The Migratory Legends. A Proposed List of Types with a Systematic Catalogue of the Norwegian Variants. FF Communications 175. Helsinki: Academia Scientarium Fennica.

Clifford, James. 1997. Routes. Travel and Translation in the Late Twentieth Century. Cambridge \& London: Harvard University Press.

Cohen, Ralph. 1991. "Genre Theory, Literary History, and Historical Change”. In: David Perkins (ed.), Theoretical Issues in Literary History. Cambridge \& London: Harvard University Press, pp. 85113.

Cooper, Helen. 2004. The English Romance in Time. Transforming Motifs from Geoffrey of Monmouth to the Death of Shakespeare. Oxford: Oxford University Press.

Correia, Alda. 2017. Narrative and Space. Across Short Story Landscapes and Regional Places. Bern: Peter Lang.

Coulter, Cornelia C. 1925. "The Happy Otherworld and Fairy Mistress Themes in the Odyssey". Transactions and Proceedings of the American Philological Association 56, pp. 37-53. https://doi.org/10.2307/282883.

Crang, Mike. 2005. “Travel/Tourism”. In David Atkinson, Peter Jackson, David Sibley, and Neil Washbourne (eds.), Cultural Geography. A Critical Dictionary of Key Concepts. London: I. B. Tauris, pp. 34-40.

Cross, Julie. 2008. "Frightening and Funny: Humor and Horror in Children's Gothic Fiction". In Anna Jackson, Karen Coats, and Roderick McGillis (eds.), The Gothic in Children's Literature. Haunting the Borders. New York \& London: Routledge, pp. 57-76.

Dan, Ilana. 1977. "The Innocent Persecuted Heroine: An Attempt at a Model for the Surface Level of the Narrative Structure of the Female Fairy Tale". In Heda Jason and Dimitri Segal (eds.), Patterns in Oral Literature. The Hague \& Paris: Mouton Publishers, pp. 13-30.

Dannenberg, Hilary P. 2008. Coincidence and Counterfactuality. Plotting Time and Space in Narrative Fiction. Lincoln \& London: University of Nebraska Press. 
Darnton, Robert. 1999[1984]. The Great Cat Massacre and Other Episodes in French Cultural History. New York: Basic Books.

Davies, Christie. 1998. Jokes and their Relation to Society. Berlin \& New York: Mouton de Gruyter.

Dégh, Linda. 1976. "Folk Narrative". In Dan Ben-Amos (ed.), Folklore Genres. Austin \& London: University of Texas Press, pp. 53-83.

-. 1979. "Grimm's Household Tales and its Place in the Household: The Social Relevance of a Controversial Classic". Western Folklore 38(2), pp. 83-103. https://doi.org/10.2307/1498562.

-. 2001. Legend and Belief: Dialectics of a Folklore Genre. Bloomington: Indiana University Press.

Dégh, Linda, and Andrew Vázsonyi. 1976[1971]. "Legend and Belief". In Dan Ben-Amos (ed.), Folklore Genres. Austin \& London: University of Texas Press, pp. 93-123.

Dennerlein, Katrin. 2009. Narratologie des Raumes. Berlin \& New York: Walter de Gruyter.

Deutsches Textarchiv. [s.a.]. http://www.deutschestextarchiv.de/.

Dewan, Pauline. 2004. The House as Setting, Symbol, and Structural Motif in Children's Literature. Lewiston, Queenston, Lampeter: Edwin Mellen Press.

Dithmar, Reinhard. 1984. "Fabel". In Kurt Ranke (ed.), Enzyklopädie des Märchens. Band 4, Lieferung 2/3. Berlin \& New York: Walter de Gruyter, pp. 727-754.

Do Rozario, Rebecca-Anne C. 2018. Fashion in the Fairy Tale Tradition. What Cinderella Wore. Cham: Palgrave Macmillan.

Doležel, Lubomír. 1998. Heterocosmica: Fiction and Possible Worlds. Baltimore: Johns Hopkins University Press.

Drory, Rina. 1977. "Ali Baba and the Forty Thieves: An Attempt at a Model for the Narrative Structure of the Reward-and-Punishment Fairy Tale". In Heda Jason and Dimitri Segal (eds.), Patterns in Oral Literature. The Hague \& Paris: Mouton, pp. 31-48.

Duda, Dean. 1998. Priča i putovanje. Hrvatski romantičarski putopis kao pripovjedni žanr. Zagreb: Matica hrvatska.

-. 2012. Kultura putovanja. Uvod u književnu iterologiju. Zagreb: Naklada Ljevak.

Duff, David (ed.). 2000. Modern Genre Theory. London: Longman.

Duggan, Anne E. 2013. Queer Enchantments. Gender, Sexuality, and Class in the Fairy-Tale Cinema of Jacques Demy. Detroit: Wayne State University Press.

Dundes, Alan. 1962. "From Etic to Emic Units in the Structural Study of Folktales". The Journal of American Folklore 75(296), pp. 95-105. https://doi.org/10.2307/538171.

-. 1964. The Morphology of North American Indian Tales. FF Communications 195. Helsinki: Academia Scientarium Fennica.

- (ed.). 1965. The Study of Folklore. Englewood Cliffs: Prentice-Hall, Inc.

—. 1968. "Introduction to the second edition". In Vladimir Propp, The Morphology of the Folktale. Austin: University of Texas Press, pp. xi-xvii.

-. 1975. "On the Structure of the Proverb". Proverbium 25, pp. 961-973.

—. 1980[1964]. "Texture, Text, and Context". In Alan Dundes, Interpreting Folklore. Bloomington: Indiana University Press, pp. 20-32.

—. 1987. "The Psychoanalytic Study of the Grimms' Tales with Special Reference to 'The Maiden Without Hands' (AT 706)". Germanic Review 62(2), pp. 50-65. https://doi.org/10.1080/ 00168890.1987 .9934192$.

—. 1988. "Interpreting Little Red Riding Hood Psychoanalytically". In James M. McGlathery (ed.), The Brothers Grimm and the Folktale. Urbana \& Chicago: University of Illinois Press, pp. 16-51.

-. 1991. "Bruno Bettelheim's Uses of Enchantment and Abuses of Scholarship". The Journal of American Folklore 104(411), pp. 74-83. https://doi.org/10.2307/541135.

—. 1997. "The Motif-Index and the Tale Type Index: A Critique". Journal of Folklore Research 34(3), pp. 195-202.

—. 2007[1964]. "On Game Morphology: A Study of the Structure of Non-Verbal Folklore". In Simon J. Bronner (ed.), The Meaning of Folklore. The Analytical Essays of Alan Dundes. Logan: Utah State University Press, pp. 154-163. https://doi.org/10.2307/j.ctt4cgrzn.12. 
Eco, Umberto. 1984[1979]. The Role of the Reader: Explorations in the Semiotics of Texts. Bloomington: Indiana University Press.

Egeler, Matthias. 2018. Atlantic Outlooks on Being at Home: Gaelic Place-Lore and the Construction of a Sense of Place in Medieval Iceland. FF Communications 314. Helsinki: Academia Scientarium Fennica.

Ekman, Stefan. 2013. Here be Dragons. Exploring Fantasy Maps and Settings. Middletown: Wesleyan University Press.

Eliade, Mircea. 1987[1957]. The Sacred and the Profane. The Nature of Religion. Trans. Willard R. Trask. New York: Harcourt, Inc.

Fairfield, Joy Brooke. 2012. "Becoming-Mouse, Becoming-Man: The Sideways Growth of Princess Mouseskin”. In Kay Turner and Pauline Greenhill (eds.), Transgressive Tales: Queering the Grimms. Detroit: Wayne State University Press, pp. 223-243.

Forster, Edward Morgan. 1985[1927]. Aspects of the Novel. Sand Diego, New York, \& London: Harcourt, Inc.

Foucault, Michel. 1986[1984]. “Of Other Spaces”. Trans. Jay Miskowiec. Diacritics 16(1), pp. $22-27$. https://doi.org/10.2307/464648.

Franks, Beth. 2001. "Gutting the Golden Goose: Disability in Grimms' Fairy Tales”. In James C. Wilson and Cynthia Lewiecki-Wilson (eds.), Embodied Rhetorics: Disability in Language and Culture. Carbondale and Edwardsville: Southern Illinois University Press, pp. 244-258.

Franz, Marie-Louise von. 1980. The Psychological Meaning of Redemption Motifs in Fairytales. Toronto: Inner City Books.

- 1996[1970]. The Interpretation of Fairy Tales. Revised edn. Boston \& London: Shambhala.

Fraser, Lucy. 2017. The Pleasures of Metamorphosis. Japanese and English Fairy Tale Transformations of 'The Little Mermaid'. Detroit: Wayne State University Press.

Frau Holle (Illustrationen). [s.a.]. Available at: https://grimmbilder.fandom.com/de/wiki/ Frau_Holle_(Illustrationen).

Freud, Sigmund. 1997[1913]. "The Occurrence in Dreams of Material from Fairy Tales”. In Sigmund Freud, Writings on Art and Literature. Standford: Stanford University Press, pp. 101-108.

Frow, John. 2006. Genre. London \& New York: Routledge.

Gehrts, Heino. 1984 “Der Wald”. In Jürgen Janning and Heino Gehrts (eds.), Die Welt im Märchen. Kassel: Eric Röth Verlag, pp. 37-53.

Gelder, Ken. 1994. Reading the Vampire. London \& New York: Routledge.

Genette, Gérard. 1976[1969]. "Boundaries of Narrative". Trans. Anna Levonas. New Literary History 8(1), pp. 1-13. https://doi.org/10.2307/468611.

-. 1983[1972]. Narrative Discourse. An Essay in Method. Trans. Jane E. Lewin. Ithaca, New York: Cornell University Press.

Georges, Robert A., and Alan Dundes. 1963. "Toward a Structural Definition of the Riddle". The Journal of American Folklore 76(300), pp. 111-118. https://doi.org/10.2307/538610.

Gerndt, Helge. 1997. “Meer”. In Kurt Ranke (ed.), Enzyklopädie des Märchens. Band 9, Lieferung 1. Berlin \& New York: Walter de Gruyter, pp. 472-478.

Gilbert, Sandra M., and Susan Gubar. 2002[1979]. The Madwoman in the Attic: The Woman Writer and the Nineteenth-Century Literary Imagination. 2nd edn. New Haven \& London: Yale University Press.

Goga, Nina, and Bettina Kümmerling-Meibauer. 2017. Maps and Mapping in Children's Literature. Landscapes, Seascapes and Cityscapes. Amsterdam, Philadelphia: John Benjamins Publishing Company.

Goldberg, Christine. 2000. “Gretel's Duck: The Escape from the Ogre in AaTh 327”. Fabula 41(1/2), pp. 42-51. https://doi.org/10.1515/fabl.2000.41.1-2.42.

Goldenberg, Naomi R. 1976. “A Feminist Critique of Jung”. Signs: Journal of Women in Culture and Society 2(2), pp. 443-440. https://doi.org/10.1086/493369. 
Goldstein, Kevin. 2012. "Nurtured in a Lonely Place: The Wise Woman as Type in 'The Goose Girl at the Spring". In Kay Turner and Pauline Greenhill (eds.), Transgressive Tales: Queering the Grimms. Detroit: Wayne State University Press, pp. 49-67.

Gomel, Elana. 2014. Narrative Space and Time. Representing Impossible Topologies in Literature. New York \& London: Routledge.

Gottschall, Jonathan, Kacey Anderson, Chad Burbank, Jasper Burch, Chelsea Byrnes, Christine Callanan, Nicole Casamento, Amy Gardiner, Natalie Gladd, Allison Hartnett, Elisabeth Henry, Eloise Hilarides, Chelsea Lemke, Kristen Manganini, Sara Merrihew, Tonya Milan-Robinson, Patrick O'Connell, Jessica Mott, Kimberly Parker, Karlin Revoir, Nathan Riley, Darcie Robinson, Sheila Rodriguez, Chelsea Sauve, April Spearance, Valerie Stucker, Adam Tapply, Alexa Unser, Christopher Wall, Alexis Webb, and Melinda Zocco. 2008. "The 'Beauty Myth' is No Myth. Emphasis on Male-Female Attractiveness in World Folktales". Human Nature 19(2), pp. 174-188. https://doi.org/10.1007/s12110-008-9035-3.

Gray, Jonathan, and Amanda D. Lotz. 2012. Television Studies. Cambridge: Polity Press.

Greenhill, Pauline. 2008. "Fitcher's [Queer] Bird': A Fairy-Tale Heroine and her Avatars". Marvels \& Tales 22(1), pp. 143-167.

—. 2015. “'The Snow Queen': Queer Coding in Male Directors' Films”. Marvels \& Tales 29(1), pp. 110-134. https://doi.org/10.13110/marvelstales.29.1.0110.

Greenhill, Pauline, and Emilie Anderson-Grégoire. 2014. “'If Thou be Woman, be Now Man!' 'The Shift of Sex' as Transsexual Imagination”. In Pauline Greenhill and Diane Tye (eds.), Unsettling Assumptions. Tradition, Gender, Drag. Logan: Utah State University Press, pp. 56-73.

Greenhill, Pauline, Anita Best, and Emilie Anderson-Grégoire. 2012. "Queering Gender: Transformations in 'Peg Bearskin', 'La Poiluse', and Related Tales”. In Kay Turner and Pauline Greenhill (eds.), Transgressive Tales: Queering the Grimms. Detroit: Wayne State University Press, pp. 181-205.

Greenhill, Pauline, and Sidney Eve Matrix. 2010. "Envisioning Ambiguity. Fairy Tale Films". In Pauline Greenhill and Sidney Eve Matrix (eds.), Fairy Tale Films. Visions of Ambiguity. Logan: Utah State University Press, pp. 1-22.

Greenhill, Pauline, Jill Terry Rudy, Naomi Hamer, and Lauren Bosc (eds.). 2018. The Routledge Companion to Media and Fairy-Tale Cultures. New York: Routledge.

Greenwood, Susan. 2000. Magic, Witchcraft and the Otherworld: An Anthropology. Oxford \& New York: Berg.

Grenby, Matthew O. 2008. Children's Literature. Edinburgh: Edinburgh University Press.

Grimm, Jacob and Wilhelm. 1816. "Vorrede". In Jacob and Wilhelm Grimm, Deutsche Sagen. Berlin: Nicolaischen Buchhandlung, pp. v-xxvi.

-. 1857a. Kinder und Hausmärchen. Gesammelt durch die Brüder Grimm. Band 1. 7th edn. Göttingen: Dieterich. Available at: http://www.deutschestextarchiv.de/book/show/grimm_maerchen02_1857.

-. 1857b. Kinder und Hausmärchen. Gesammelt durch die Brüder Grimm. Zweiter Band. 7th edn. Göttingen: Dieterich. Available at: http://www.deutschestextarchiv.de/book/show/ grimm_maerchen02_1857.

—. 2003[1857]. The Complete Fairy Tales of the Brothers Grimm. Trans. Jack Zipes. 3rd edn. New York, Toronto, London, Sydney, \& Auckland: Random House, Inc.

—. 2007[1822]. "Aus dem Anmerkungsband von 1822 (Ersatzweise aus 1856)". In Heinz Rölleke (ed.), Kinder- und Hausmärchen gesammelt durch die Brüder Grimm. Vollständige Ausgabe auf der Grundlage der dritten Auflage (1837). Frankfurt am Main: Deutscher Klassiker-Verlag, pp. 863-1108.

Grzywka, Katarzyna. 2018. "Wirtshäuser in polnischen Märchen”. Fabula 59(3-4), pp. 245-264. https://doi.org/10.1515/fabula-2018-0102.

Gutierrez, Anna Katrina. 2017. Mixed Magic. Global-Local Dialogues in Fairy Tales for Young Readers. Amsterdam \& Philadelphia: John Benjamins Publishing Company. 
Haase, Donald. 2000. "Children, War and the Imaginative Space of Fairy Tales". The Lion and the Unicorn 24(3), pp. 360-377. https://doi.org/10.1353/uni.2000.0030.

—. 2004. "Feminist Fairy-Tale Scholarship". In Donald Haase (ed.), Fairy Tales and Feminism. New Approaches. Detroit: Wayne State University Press, pp. 1-36.

-. 2008a. "Introduction". In Donald Haase (ed.), The Greenwood Encyclopedia of Folktales and Fairy Tales. Westport: Greenwood Press, pp. xxxiii-xxxix.

-. (ed.). 2008b. The Greenwood Encyclopedia of Folktales and Fairy Tales. Volumes 1-3. Westport \& London: Greenwood Press.

—. 2016. "Challenges of Folktale and Fairy-Tale Studies in the Twenty-First Century". Fabula 57(12), pp. 73-85. https://doi.org/10.1515/fabula-2016-0006.

Hagelberg, Gerhard Hans Bernhard. 2003. "Sugar and Sweeteners". In Solomon H. Katz (ed.), Encyclopedia of Food and Culture. Vol. 3. Obesity to Zoroastrianism. New York: Charles Scribner's Sons, pp. 358-363.

Hala, Jim. 1992. "Fatal Attraction and the Attraction of Fables: A Morphological Analysis". Journal of Popular Culture 26(3), pp. 71-82. https://doi.org/10.1111/j.0022-3840.1992.2603_71.x.

Hameršak, Marijana. 2011. Pričalice. O povijesti djetinjstva i bajke. Zagreb: Algoritam.

—. 2012. "Životinja i žanr ili Priča o kozlićih". In Suzana Marjanić and Antonija Zaradija Kiš (eds.), Književna životinja. Kulturni bestijarij, II. dio. Zagreb: Hrvatska sveučilišna naklada \& Institut za etnologiju i folkloristiku, pp. 849-867.

—. 2015. "Središte ruba: životinje i dječja književnost". Detinjstvo 15(2), pp. 29-39.

Harries, Elizabeth Wanning. 2003[2001]. Twice upon a Time. Women Writers and the History of the Fairy Tale. New Jersey: Princeton University Press.

Harris, Chandler. 2008. "Policing Propp: Toward a Textualist Definition of the Procedural Drama". Journal of Film and Video 60(1), pp. 43-59. https://doi.org/10.1353/jfv.2008.0001.

Harrison, Robert Pogue. 1992. Forests: The Shadow of Civilization. Chicago: University of Chicago Press.

Harvey, David. 1994. "The Social Construction of Space and Time: A Relational Theory". Geographical Review of Japan 67(2), pp. 126-135.

-. 2004. "Space as a Key Word". Paper for Marx and Philosophy Conference, 29 May 2004, Institute of Education, London. Available at: http://frontdeskapparatus.com/files/harvey2004.pdf.

Harvilahti, Lauri. 2012. "Finland". In Regina F. Bendix and Galit Hasan-Rokem (eds.), A Companion to Folklore. Malden: Wiley-Blackwell, pp. 391-408.

Heindrichs, Ursula. 1984. "Der Brunnen”. In Jürgen Janning and Heino Gehrts (eds.), Die Welt im Märchen. Kassel: Eric Röth Verlag, pp. 53-74.

Heinen, Sandra, and Roy Sommer (eds.). 2009. Narratology in the Age of Cross-Disciplinary Narrative Research. Berlin \& New York: Walter de Gruyter.

Heisig, James W. 1977. "Bruno Bettelheim and the Fairy Tales". Children's Literature 6, pp. 93-114. https://doi.org/10.1353/chl.0.0380.

Hennard Dutheil de la Rochère, Martine. 2009. "Queering the Fairy Tale Canon: Emma Donoghue's Kissing the Witch". In Susan Redington Bobby (ed.), Fairy Tales Reimagined. Essays on New Retellings. Jefferson: McFarland, pp. 13-30.

Henninger, Joseph. 1949. "Der geographische Horizont der Erzähler von 1001 Nacht". Geographica Helvetica 4, pp. 214-229. https://doi.org/10.5194/gh-4-214-1949.

Herman, David. 2002. Story Logic. Problems and Possibilities of Narrative. Lincoln \& London: University of Nebraska Press.

—. 2009. Basic Elements of Narrative. Chichester: Wiley-Blackwell.

Holbek, Bengt. 1987. Interpretation of Fairy Tales. Danish Folklore in a European Perspective. FF Communications 239. Helsinki: Academia Scientarium Fennica.

Holquist, Michael. 2002[1990]. Dialogism. Bakhtin and his World. 2nd edn. New York: Routledge.

Hones, Sheila. 2014. Literary Geographies. Narrative Space in Let the Great World Spin. New York: Palgrave Macmillan. 
Honko, Lauri. 1969. Genre Analysis in Folkloristics and Comparative Religion. Turku: University of Turku \& Institute of Folklore and Comparative Religion.

—. 1989. "Folkloristic Theories of Genre". In Anna-Leena Siikala (ed.), Studies in Oral Narrative. Helsinki: Suomalaisen Kirjallisuuden Seura, pp. 13-28.

-. 2013[1981]. "Four Forms of Adaptation of Tradition". In Pekka Hakamies and Anneli Honko (eds.), Theoretical Milestones. Selected Writings of Lauri Honko. FF Communications 304. Helsinki: Academia Scientarium Fennica, pp. 173-188.

Hoogenboezem, Daphne M. 2010. "Medievalism and Magic: Illustrating Classical French Fairy Tales". In Alicia Montoya, Sophie van Romburgh, and Wim van Anrooij (eds.), Early Modern Medievalism. The Interplay between Scholarly Reflection and Artistic Production. Leiden \& Boston: Brill, pp. 249-284. https://doi.org/10.1163/ej.9789004187665.i-472.88

Horn, Katalin. 1977. "Das Kleid als Ausdruck der Persönlichkeit: Ein Beitrag zum Identitätsproblem im Volksmärchen". Fabula 18(1), pp. 75-104. https://doi.org/10.1515/fabl.1977.18.1.75.

Hühn, Peter, Wolf Schmid, and Jörg Schönert (eds.). 2009. Point of View, Perspective, and Focalization. Modeling Mediation in Narrative. Berlin \& New York: Walter de Gruyter.

Hume, Kathryn. 1984. Fantasy and Mimesis. Responses to Reality in Western Literature. New Haven \& London: Methuen.

Hutcheon, Linda. 1985. A Theory of Parody. The Teachings of Twentieth-Century Art Forms. London: Methuen.

Hyde, Lewis. 1998. Trickster Makes This World. Mischief, Myth, and Art. New York: Farrar, Straus, and Giroux.

Ingarden, Roman. 1973[1931]. The Literary Work of Art. An Investigation on the Borderlines of Ontology, Logic, and Theory of Literature. Trans. George G. Grabowicz. Evanston: Northwestern University Press.

Ingemark, Camilla Asplund. 2006. "The Chronotope of Enchantment". Journal of Folklore Research 43(1), pp. 1-30. https://doi.org/10.2979/jfr.2006.43.1.1.

Into the Woods. 1986. Steven Sondheim (music, lyrics) and James Lapine (book).

Iser, Wolfgang. 1974[1972]. The Implied Reader. Patterns of Communication in Prose Fiction from Bunyan to Beckett. Baltimore \& London: The Johns Hopkins Unversity Press.

Ivleva, Victoria. 2009. "Functions of Textile and Sartorial Artifacts in Russian Folktales". Marvels \& Tales 23(2), pp. 268-299.

Jackson, Rosemary. 1991[1981]. Fantasy: The Literature of Subversion. London \& New York: Routledge.

Jahn, Manfred. 1996. "Windows of Focalization: Deconstructing and Reconstructing a Narratological Concept”. Style 30(2), pp. 241-267.

—. 2017. Narratology: A Guide to the Theory of Narrative. Köln: English Department, University of Cologne. Retrieved from http://www.uni-koeln.de/ ame02/pppn.htm.

Jameson, Frederic. 2006[1981]. The Political Unconscious. Narrative as a Socially Symbolic Act. London \& New York: Routledge.

Järv, Risto. 2005. "The Gender of the Heroes, Storytellers and Collectors of Estonian Fairy Tales". Folklore. Electronic Journal of Folklore 29, pp. 45-60. https://doi.org/10.7592/ FEJF2005.29.gender.

Jason, Heda. 1971. "Concerning the 'Historical' and the 'Local' Legends and their Relatives". The Journal of American Folklore 84(331), pp. 134-144. https://doi.org/10.2307/539740.

-. 1972. "Jewish-Near Eastern Numskull Tales: An Attempt at Interpretation". Asian Folklore Studies 31(1), pp. 1-39. https://doi.org/10.2307/1177536.

—. 1977a. "A Model for Narrative Structure in Oral Literature". In Heda Jason and Dimitri Segal (eds.), Patterns in Oral Literature. The Hague \& Paris: Mouton Publishers, pp. 99-139. https://doi.org/10.1515/9783110810028.99.

-. 1977b. Ethnopoetry. Form, Content, Function. Bonn: Linguistica Biblica. 
—. 1977c. "Precursors of Propp: Formalist Theories of Narrative in Early Russian Ethnopoetics". PTL: A Journal for Descriptive Poetics and Theory of Literature 3, pp. 477-485.

—. 1978. "Aspects of the Fabulous in Oral Literature". Fabula 19(1), pp. 14-31. https://doi.org/10.1515/fabl.1978.19.1.14.

-. 1979. "The Poor Man of Nippur: An Ethnopoetic Analysis". Journal of Cuneiform Studies 31(4), pp. 189-215. https://doi.org/10.2307/1359751.

- 1988. Whom does God Favor: The Wicked or the Righteous? The Reward-and-Punishment Fairy Tale. FF Communications 240. Helsinki: Academia Scientarium Fennica.

—. 2000. Motif, Type and Genre. FF Communications 273. Helsinki: Academia Scientarium Fennica.

Jindra, Michael. 2003. "Natural/supernatural conceptions in Western cultural contexts". Anthropological Forum 13(2), pp. 159-166. https://doi.org/10.1080/0066467032000129824.

Johansson, Ingvar. 2004[1989]. Ontological Investigations. An Inquiry into the Categories of Nature, Man and Society. Frankfurt, Lancaster: Ontos Verlag.

Jolles, André. 1969[1930]. Einfache Formen. Legende, Sage, Mythe, Rätsel, Spruch, Kasus, Memorabile, Märchen, Witz. 4th edn. Darmstadt: Wissenschaftliche Buchgesellschaft.

Jones, Ernest. 1951. "Psycho-Analysis and Folklore". In Ernest Jones, Essays in Applied PsychoAnalysis. Vol II. Essays in Folklore, Anthropology and Religion. London: The Hogarth Press, Ltd. \& The Institute of Psycho-Analysis, pp. 1-21.

Jones, Steven Swann. 2002[1995]. The Fairy Tale. The Magic Mirror of the Imagination. New York \& London: Routledge.

Jong, Irene J. F. de. 2012a. "Introduction. Narratological Theory on Space". In Irene J. F. de Jong (ed.), Space in Ancient Greek Literature. Leiden \& Boston: Brill, pp. 1-18.

- (ed.). 2012b. Space in Ancient Greek Literature. Studies in Ancient Greek Narrative, Volume Three. Leiden \& Boston: Brill.

Joosen, Vanessa. 2009. "Philip Pullman's I was a Rat! and the Fairy-Tale Retelling as Instrument of Social Criticism". In Susan Redington Bobby (ed.), Fairy Tales Reimagined: Essays on New Retellings. Jefferson: McFarland, pp. 196-209.

- 2011. Critical and Creative Perspectives on Fairy Tales. An Intertextual Dialogue between FairyTale Scholarship and Postmodern Retellings. Detroit: Wayne State University Press.

Jorgensen, Jeana. 2007. "A Wave of the Magic Wand: Fairy Godmothers in Contemporary American Media". Marvels \& Tales 21(2), pp. 216-227.

- 2014. "Quantifying the Grimm Corpus: Transgressive and Transformative Bodies in the Grimms' Fairy Tales". Marvels \& Tales 28(1), pp. 127-141. https://doi.org/10.13110/marvelstales.28.1.0127.

—. 2019. "The Most Beautiful of All: A Quantitative Approach to Fairy-Tale Femininity". The Journal of American Folklore 132(523), pp. 36-60. https://doi.org/10.5406/jamerfolk.132.523.0036.

Jung, Carl Gustav. 1964. Man and his Symbols. New York, Toronto, London, Sydney, \& Auckland: Anchor Press.

—. 1991[1969]. "The Phenomenology of the Spirit in Fairy Tales". Trans. R. F. C. Hull. In Sir Herbert Read, Michael Fordham, and Gerhard Adler (eds.), C. G. Jung. The Collected Works. Volume Nine. Part One. The Archetypes and the Collective Unconscious. 2nd edn. London: Routledge, pp. 207254.

Karlinger, Felix. 1984. “Das Meer”. In Jürgen Janning and Heino Gehrts (eds.), Die Welt im Märchen. Kassel: Eric Röth Verlag, pp. 84-92.

Karlsson Marcussen, Marlene. 2016. Reading for Space. An Encounter between Narratology and New Materialism in the Works of Virigina Wolf and Georges Perec. PhD thesis. Odense: University of Southern Denmark.

Kawan, Christine Shojaei. 2012. "Wirt, Wirtin, Wirtshaus". In Kurt Ranke (ed.), Enzyklopädie des Märchens. Band 14, Lieferung 2. Berlin \& New York: De Gruyter.

Klass, Morton. 1995. Ordered Universes. Approaches to the Anthropology of Religion. Boulder, Oxford: Westview Press. 
Klintberg, Bengt af. 2010. The Types of the Swedish Folk Legend. FF Communications 300. Helsinki: Academia Scientarium Fennica.

Koski, Kaarina, Frog, and Ulla Savolainen (eds). 2016. Genre - Text - Interpretation. Multidisciplinary Perspectives on Folklore and Beyond. Helsinki: The Finnish Literature Society.

Krikmann, Arvo. 2008. "AATU Jokes': Old and Abandoned". Retrieved from http://haldjas.folklore.ee/ kriku/HUUMOR/KRIKMANN_ATU_ready.pdf.

Kujundžić, Nada. 2012a. "Didactic Tales, Formula Tales, and Tall Tales in Grimms' Kinder- und Hausmärchen". Libri \& Liberi 1(2), pp. 179-196. https://doi.org/10.21066/carcl.libri.201201(02).0039.

-. 2012b. "Flying Horses and Magic Carpets. Means of Transport in Select Slavic Fairy Tales for Young Readers". Narodna umjetnost: Croatian journal of ethnology and folklore research 49(1), pp. 81-94.

-. 2014. "Moving (Up) in the World: Displacement, Transformation and Identity in the Grimms' Fairy Tales". Libri \& Liberi 3(2), pp. 221-237. https://doi.org/10.21066/carcl.libri.201403(02).0018.

-. 2016. "The Moral Meets the Marvellous". The ESSE Messenger 25(1), pp. 68-80.

-. (forthcoming). "Inverting the Brave Hero Narrative: Parodic Function of Fear/lessness in Two Grimms' Fairy Tales". In Natka Badurina, Ina Bauer, and Jelena Marković (eds.), Narrating Fear. Zagreb: Institut za etnologiju i folkloristiku.

Kukkonen, Karin. 2008. "Popular Cultural Memory. Comics, Communities and Context Knowledge". Nordicom Review 29(2), pp. 261-273. https://doi.org/10.1515/nor-2017-0190.

-. 2013. Contemporary Comics Storytelling. Lincoln \& London: University of Nebraska Press.

-. 2014. "Bayesian Narrative: Probability, Plot and the Shape of the Fictional World". Anglia 132(4), pp. 720-739. https://doi.org/10.1515/ang-2014-0075.

Kvideland, Reimund. 2005. "Schreckmärchen“. In Kurt Ranke (ed.), Enzyklopädie des Märchens. Band 12, Lieferung 1. Berlin \& New York: De Gruyter, pp. 190-192.

Lachmann, Renate. 2002. Phantasia / Memoria / Rhetorica. Trans. Davor Beganović. Zagreb: Matica hrvatska.

Laine, Marlene de. 2000. Fieldwork, Participation and Practice: Ethics and Dilemmas in Qualitative Research. London, Thousand Oaks, New Delhi: Sage Publications.

Lakoff, George, and Mark Johnson. 2003[1980]. Metaphors We Live By. Chicago \& London: The University of Chicago Press.

Lau, Kimberly J. 2015. Erotic Infidelities: Love and Enchantment in Angela Carter's The Bloody Chamber. Detroit: Wayne State University Press.

Lauter, Estella, and Carol Schreier Rupprecht (eds.). 1985. Feminist Archetypal Theory: Interdisciplinary Re-Visions of Jungian Thought. Knoxville: University of Tennessee Press.

Leane, Elizabeth. 2016. "Unstable Places and Generic Spaces: Thrillers Set in Antarctica". In Lisa Fletcher (ed.), Popular Fiction and Spatiality. Reading Genre Settings. New York: Palgrave Macmillan, pp. 25-43.

Leeuwen, Richard van. 2007. The Thousand and One Nights. Space, Travel and Transformation. London \& New York: Routledge.

Lefebvre, Henri. 1991[1974]. The Production of Space. Trans. Donald Nicholson-Smith. Oxford, UK \& Cambridge, USA: Blackwell Publishers.

Lessing, Gotthold Ephraim. 1887[1766]. Laocoon. An Essay upon the Limits of Painting and Poetry. With Remarks Illustrative of Various Points in the History of Ancient Art. Trans. Ellen Frothingham. Boston: Roberts Brothers.

Lévi-Strauss, Claude. 1984[1958]. "Structure and Form: Reflections on a Work by Vladimir Propp". Trans. Monique Layton. In Vladimir Propp, Theory and History of Folklore. Minneapolis: University of Minnesota Press, pp. 167-188.

Levorato, Alessandra. 2003. Language and Gender in the Fairy Tale Tradition. A Linguistic Analysis of Old and New Storytelling. New York: Palgrave Macmillan. 
Liberman, Anatoly. 1984. "Introduction". In Vladimir Propp, Theory and History of Folklore. Minneapolis: University of Minnesota Press, pp. ix-lxxxi.

Liddell, Robert. 1947. A Treatise on the Novel. London: Jonathan Cape.

Lieberman, Marcia R. 1972. "'Some Day My Prince will Come': Female Acculturation through the Fairy Tale". College English 34(3), pp. 383-395. https://doi.org/10.2307/375142.

Likhachev, Dmitry Sergeyevich. 2014[1967]. The Poetics of Early Russian Literature. Ed. and trans. Christopher M. Arden-Close. Lanham, Boulder, New York, Toronto, \& Plymouth: Lexington Books.

Lindahl, Carl. 2018. "Definition and History of Fairy Tales". In Pauline Greenhill, Jill Terry Rudy, Naomi Hamer, and Lauren Bosc (eds.), The Routledge Companion to Media and Fairy-Tale Cultures. New York: Routledge, pp. 11-19.

Linde, Charlotte, and William Labov. 1975. "Spatial Networks as a Site for the Study of Language and Thought". Language 51(4), pp. 924-939. https://doi.org/10.2307/412701.

Lohmann, Roger Ivar (ed.). 2003. Anthropological Forum (Special Issue). Perspectives on the Category 'Supernatural'. 13(2).

Lotman, Juri. 1977[1970]. The Structure of the Artistic Text. Trans. Ronald Vroon. Ann Arbor: University of Michigan.

- 1990. Universe of the Mind. A Semiotic Theory of Culture. Trans. Ann Shukman. Bloomington \& Indianapolis: Indiana University Press.

Lundell, Torborg. 1986. "Gender-Related Biases in the Type and Motif Indexes of Aarne and Thompson”. In Ruth Bottigheimer (ed.), Fairy Tales and Society. Illusion, Allusion, and Paradigm. Philadelphia: University of Pennsylvania Press, pp. 149-163. https://doi.org/10.9783/9780812201505.149.

Lurie, Alison. 1970. "Fairy Tale Liberation”. New York Review of Books, 17 December 1970, pp. $42-$ 43. Retrieved from http://www.nybooks.com/articles/1970/12/17/fairy-tale-liberation/.

Lüthi, Max. 1970. "Gebrechliche und Behinderte im Volksmärchen”. In Max Lüthi (ed.), Volksliteratur und Hochliteratur: Menschenbild - Thematik - Formstreben. Bern \& München: Francke Verlag, pp. 48-62.

-. 1970[1962]. Once upon a Time. On the Nature of Fairy Tales. Trans. Lee Chadeayne and Paul Gottwald. Bloomington: Indiana University Press.

—. 1974. Märchen. Stuttgart: J. B. Metzlersche Verlagsbuchhandlung.

—. 1976[1969]a. "Aspects of the Märchen and the Legend". In Dan Ben-Amos (ed.), Folklore Genres. Austin: University of Texas Press, pp. 17-33.

—. 1976[1969]b. So leben sie noch heute. Betrachtungen zum Volksmärchen. 2nd edn. Göttingen: Vandenhoeck \& Ruprecht.

—. 1986[1947]. The European Folktale: Form and Nature. Trans. John D. Niles. Bloomington \& Indianapolis: Indiana University Press.

-. 1987[1975]. The Fairy Tale as Art Form and Portrait of Man. Trans. Jon Erickson. Bloomington: Indiana University Press.

Lutwack, Leonard. 1984. The Role of Place in Literature. Syracuse, New York: Syracuse University Press.

MacDonald, Ruth. 1982. "The Tale Retold: Feminist Fairy Tales". Children's Literature Association Quarterly, 7(2), pp. 18-20. https://doi.org/10.1353/chq.0.0251.

Mackintosh, Fiona. 2004. "Babes in the Bosque: Fairy Tales in Twentieth-Century Argenite Women's Writing". In Donald Haase (ed.), Fairy Tales and Feminism. New Approaches. Detroit: Wayne State University Press, pp. 149-167.

Maitland, Sara. 2012. From the Forest. A Search for the Hidden Roots of Our Fairy Tales. Berkeley: Counterpoint.

Malmgren, Carl Darryl. 1985. Fictional Space in the Modernist and Postmodernist American Novel. London \& Toronto: Bucknell University Press. 
Maranda, Pierre, and Elli Köngäs Maranda. 1971. "Structural Models in Folklore”. In Elli Köngäs Maranda and Pierre Maranda (eds.), Structural Models in Folklore and Transformational Essays. The Hague \& Paris: Mouton, pp. 16-94. https://doi.org/10.1515/9783110900552-002.

Marcus, Leonard S. 1983/84. "Picture Book Animals: How Natural a History?". The Lion and the Unicorn 7(8), pp. 127-139. https://doi.org/10.1353/uni.0.0219.

Massey, Doreen. 1999a. Power-Geometries and the Politics of Space-Time: Hettner-Lecture 1998. Heidelberg: Department of Geography, University of Heidelberg.

—. 1999b. "Spaces of Politics". In Doreen Massey, John Allen, and Phil Sarre (eds.), Human Geography Today. Cambridge: Polity Press, pp. 279-294.

- 2005. For Space. London: Sage Publications.

Mays, Kelly J. (ed.). 2017[1973]. The Norton Introduction to Literature. Shorter 12th edn. New York \& London: W. W. Norton \& Company.

Meder, Oskar. 1988. “'Wehe du verläßt mich!' Sozial-geographische Anmerkungen zur Bedeutung des Waldes in den Märchen 'Hänsel und Gretel' sowie 'Rotkäppchen'”. In Peter Jüngst and Oskar Meder (eds.), Raum als Imagination und Realität. Zu seinem latenten und manifesten Sinn im sozialen und ökonomischen Handeln. Kassel: Selbstverlag Gesamthochschulbibliothek Kassel, pp. 122-146.

Meister, Jan Christoph. 2014[2009]. "Narratology”. In Peter Hühn, Jan Christoph Meister, John Pier, and Wolf Schmid (eds.), Hanbook of Narratology. Volume 2. 2nd fully revised and expanded edn. Berlin \& Boston: Walter de Gruyter, pp. 623-645. https://doi.org/10.1515/9783110316469.623.

Meletinskij, Eleazar, Sergey Nekludov, Elena Novik, and Dimitri Segal. 1974[1971]. "Problems of the structural analysis of fairytales". Trans. Terrell Popoff and Helen Milosevich. In Pierre Maranda (ed.), Soviet Structural Folkloristics, Vol 1. The Hague: Mouton, pp. 73-139. https://doi.org/10.1515/9783110828047.73.

Mendlesohn, Farah. 2008. Rhetorics of Fantasy. Middletown: Wesleyan University Press.

Mendelson, Michael. 1997 "Forever Acting Alone: The Absence of Female Collaboration in Grimms' Fairy Tales". Children's Literature in Education 28(3), pp. 111-125. https://doi.org/10.1023/A:1022427318133.

Messerli, Alfred. 2003. "Raumvorstellung”. In Kurt Ranke (ed.), Enzyklopädie des Märchens. Band 11, Lieferung 1. Berlin \& New York: Waler de Gruyter, pp. 356-364.

-. 2005. "Spatial Representation in European Popular Fairy Tales". Marvels \& Tales 19(2), pp. 274 284. https://doi.org/10.1353/mat.2005.0034.

-. 2019. "Zur narrativen Raumkonstruktion des Märchenschlosses". Fabula 60(1-2), pp. 20-37. https://doi.org/10.1515/fabula-2019-0003.

Mickelsen, David. 1981. "Types of Spatial Structure in Narrative". In Jeffrey R. Smitten and Ann Daghistany (eds.), Spatial Form in Narrative. Ithaca \& London: Cornell University Press, pp. 6378.

Mikkonen, Kai. 2007. "The 'Narrative is Travel' Metaphor: Between Spatial Sequence and Open Consequence". Narrative 15(3), pp. 286-305. https://doi.org/10.1353/nar.2007.0017.

Mitchell, David T., and Sharon L. Snyder. 2000. Narrative Prosthesis: Disability and the Dependencies of Discourse. Ann Arbor: University of Michigan Press.

Molvarec, Lana. 2010. "Putovanje kao izraz krize subjekta-putnika". In Nikola Batušić et al. (eds.), Dani Hvarskoga kazališta. Sv. 36. Putovanje, lutanje i bijeg u hrvatskoj književnosti. Split: Hrvatska akademija znanosti i umjetnosti, Književni krug, pp. 289-313.

Moretti, Franco. 1998[1997]. Atlas of the European Novel 1800-1900. London \& New York: Verso.

Morphy, Howard. 1995. "Landscape and the Reproduction of the Ancestral Past". In Eric Hirsch and Michael O'Hanlon (eds.), The Anthropology of Landscape. Perspectives on Place and Space. Oxford: Clarendon Press, pp. 184-209.

Mosher, Harold F. 1991. "Towards a Poetics of 'Descriptized' Narration”. Poetics Today 12(3), pp. 425-445. https://doi.org/10.2307/1772646. 
Muhawi, Ibrahim. 2001. "Gender and Disguise in the Arabic Cinderella: A Study in the Cultural Dynamics of Representation". Fabula 42(3-4), pp. 263-283. https://doi.org/10.1515/ fabl.2002.004.

Murai, Mayako. 2015. From Dog Bridegroom to Wolf Girl. Contemporary Japanese Fairy-Tale Adaptations in Conversation with the West. Detroit: Wayne State University Press.

Murphy, Terence Patrick. 2015. From Fairy Tale to Film Screenplay. Working with Plot Genotypes. London: Palgrave Macmillan.

Neumann, Siegfried. 1993. "The Brothers Grimm as Collectors and Editors of German Folktales". In Donald Haase (ed.), The Reception of Grimms' Fairy Tales: Responses, Reactions, Revisions. Detroit: Wayne State University Press, pp. 24-40.

Nicolaisen, Wilhelm F. H. 1980. "Space in Folk Narrative". In Nikolai Burlakoff and Carl Lindahl (eds.), Folklore on Two Continents. Essays in Honor of Linda Dégh. Bloomington: Trickster Press, pp. 14-18.

—. 1988. "Once upon a Place, or Where is the World of the Folktale?". In Albrecht Lehmann and Andreas Kuntz (eds.), Sichtweisen der Volkskunde. Zur Geschichte und Forschungspraxis einer Disziplin. Berlin \& Hamburg: Bietrich Reimer Verlag, pp. 359-366.

—. 1991. "The Past as Place: Names, Stories, and the Remembered Self". Folklore 102(1), pp. 3-15. https://doi.org/10.1080/0015587X.1991.9715801.

—. 1993. "Why Tell Stories about Innocent, Persecuted Heroines?". Western Folklore 52(1), pp. 6171. https://doi.org/10.2307/1499493.

Nieragden, Göran. 2002. "Focalization and Narration: Theoretical and Terminological Refinements". Poetics Today 23(4), pp. 685-697. https://doi.org/10.1215/03335372-23-4-685.

Nikiforov, Aleksandr I. 1975[1928]. "Towards a Morphological Study of the Folktale". Trans. Felix J. Oinas and Stephen Soudakoff. In Felix J. Oinas and Stephen Soudakoff (eds.), The Study of Russian Folklore. The Hague \& Paris: Mouton, pp. 155-161.

Nikolajeva, Maria. 2003. "Fairy Tale and Fantasy: From Archaic to Postmodern". Marvels \& Tales 17(1), pp. 138-156. https://doi.org/10.1353/mat.2003.0014.

Nodelman, Perry. 2008. The Hidden Adult. Defining Children's Literature. Baltimore: The Johns Hopkins Unversity Press.

Nodelman, Perry, and Mavis Reimer. 2003[1992]. The Pleasures of Children's Literature. 3rd edn. Boston: Allyn \& Bacon.

Nünning, Ansgar. 2003. "Narratology or Narratologies? Taking Stock of Recent Developments, Critique and Modest Proposals for Future Usages of the Term". In Tom Kindt and Hans-Harald Müller (eds.), What is Narratology? Questions and Answers Regarding the Status of a Theory. Berlin \& New York: Walter de Gruyter, pp. 239-276. https://doi.org/10.1515/ 9783110202069.239.

—. 2007. "Towards a Typology, Poetics and History of Description in Fiction". In Werner Wolf and Walter Bernhart (eds.), Description in Literature and Other Media. Amsterdam \& New York: Rodopi, pp. 91-128.

Odber de Baubeta, Patricia Anne. 2004. "The Fairy-Tale Intertext in Iberian and Latin American Women's Writing”. In Donald Haase (ed.), Fairy Tales and Feminism. New Approaches. Detroit: Wayne State University Press, pp. 129-147.

Olrik, Axel. 1965[1909]. "Epic Laws of Folk Narrative". Trans. Jeanne P. Steager. In Alan Dundes (ed.), The Study of Folklore. Englewood Cliffs: Prentice-Hall, pp. 129-141.

Ono, Hisako. 2007. "Waldsymbolik bei den Brüdern Grimm". Fabula 48(1-2), pp. 73-84. https://doi.org/10.1515/FABL.2007.007.

Oring, Elliott. 1986. "Folk Narratives". In Elliott Oring (ed.), Folk Groups and Folklore Genres. An Introduction. Logan: Utah State University Press, pp. 121-146.

—. 2008. "Legendry and the Rhetoric of Truth". The Journal of American Folklore 121(480), pp. 127166. https://doi.org/10.1353/jaf.0.0008. 
Orme, Jennifer. 2010. "Mouth to Mouth: Queer Desires in Emma Donoghue's Kissing the Witch". Marvels \& Tales 24(1), pp. 116-130.

—. 2015. "A Wolf's Queer Invitation: David Kaplan's Little Red Riding Hood and Queer Possibility". Marvels \& Tales 29(1), pp. 87-109. https://doi.org/10.13110/marvelstales.29.1.0087.

Palmer, Nancy, and Melvin Palmer. 1974. "English Editions of French Contes de fées Attributed to Mme D'Aulnoy". Studies in Bibliography 27, pp. 227-232.

Parker, Joshua. 2012/14. "Conceptions of Place, Space and Narrative: Past, Present and Future". Amsterdam International Electronic Journal for Cultural Narratology (AJCN) 7-8, pp. 74-101.

Pavel, Thomas. 1986. Fictional Worlds. Cambridge: Harvard University Press.

-. 2003. "Literary Genres as Norms and Good Habits". New Literary History 34(2), pp. 201-210. https://doi.org/10.1353/nlh.2003.0021.

Perco, Daniela. 1993. "Female Initiation in Northern Italian Versions of "Cinderella". Trans. Cristina Bacchilega. Western Folklore 52(1), pp. 73-84. https://doi.org/10.2307/1499494.

Perkins, Jonathan. 2008. "Finding Todorov in Russian Literary Criticism: The Struggle to Define the Fantastic". Forum for Modern Language Studies 44(4), pp. 363-378. https://doi.org/10.1093/fmls/cqn055.

Peruško, Tatjana (ed.). 2018. U labirintu teorija. O fantastici i fantastičnom. Zagreb: Hrvatska sveučilišna naklada.

Pflugmacher, Torsten. 2005. "Description”. In David Herman, Manfred Jahn, and Marie-Laure Ryan (eds.), Routledge Encyclopedia of Narrative Theory. London: Routledge, pp. 101-102.

Piatti, Barbara, Hans Rudolf Bär, Anne-Kathrin Reuschel, Lorenz Hurni, and William Cartwright. 2009. "Mapping Literature: Towards a Geography of Fiction". In William Cartwright, Georg Gartner, and Antje Lehn (eds.), Cartography and Art. Lecture Notes in Geoinformation and Cartography. Berlin \& Heidelberg: Springer, pp. 177-192.

Power, Rosemary. 1985. "Journeys to the Otherworld in the Icelandic Fornaldarsögur". Folklore 96(2), pp. 156-175. https://doi.org/10.1080/0015587X.1985.9716345.

Prince, Gerald. 1982. Narratology. The Form and Functioning of Narrative. Berlin, New York, \& Amsterdam: Mouton Publishers.

-. 2018a. "Introduction. Geographical Narratology". Frontiers of Narrative Studies 4(2), pp. 175177. https://doi.org/10.1515/fns-2018-0016.

—. 2018b. "Remarks on Narrative Space". Interdisciplinary Studies of Literature 2(1), pp. 26-33.

Propp, Vladimir. 1968[1928]. Morphology of the Folktale. 2nd edn. Trans. Laurence Scott. Austin: University of Texas Press.

—. 1990[1946]. Historijski korijeni bajke. Trans. Vida Flaker. Sarajevo: Svjetlost.

—. 2012[1984]. The Russian Folktale. Trans. \& ed. Sibelan Forrester. Detroit: Wayne State University Press.

Putnam, John Pickering. 1877. The Metric System of Weights and Measures. 2nd edn. Boston: American Metric Bureau.

Ragan, Kathleen. 2009. "What Happened to the Heroines in Folktales? An Analysis by Gender of a Multicultural Sample of Published Folktales Collected from Storytellers". Marvels \& Tales 23(2), pp. 227-247.

Ranke, Kurt (ed.). 1977-2015. Enzyklopädie des Märchens. Handwörterbuch zur historischen und vergleichenden Erzählforschung. Band 1-15. Berlin \& New York: Walter de Gruyter.

Reisz, Susana. 2017[1979]. "Fantastična fikcija i njezina povezanost s drugim tipovima fikcije". In Tatjana Peruško (ed.), O fantastici i fantastičnom. Izbor teorijskih rasprava o fantastičnoj književnosti. Zagreb: Hrvatska sveučilišna naklada, pp. 149-174.

Ricoeur, Paul. 1980. "Narrative Time". Critical Inquiry 7(1), pp. 169-190. https://doi.org/10.1086/448093.

Riffaterre, Michael. 1981. "Descriptive Imagery". Yale French Studies 61, pp. 107-125. https://doi.org/10.2307/2929879. 
Rimmon-Kenan, Shlomith. 1983. Narrative Fiction. Contemporary Poetics. London \& New York: Methuen.

Robert, Marthe, and Wyley L. Powell. 1969. "The Grimm Brothers". Yale French Studies 43, pp. 4456. https://doi.org/10.2307/2929635.

Roberts, Adam. 2006[2000]. Science Fiction. 2nd edn. London \& New York: Routledge.

Roberts, Warren Everett. 1958. The Tale of the Kind and the Unkind Girls. Aa-Th 480 and Related Tales. Berlin: Walter de Gruyter.

Robinson, Orrin W. 2007. "Does Sex Breed Gender? Pronominal Reference in the Grimms' Fairy Tales". Marvels \& Tales 21(1), pp. 107-123.

-. 2010. Grimm Language. Grammar, Gender and Genuineness in the Fairy Tales. Amsterdam: John Benjamins Publishing Company.

Röhrich, Lutz. 1991[1956]. Folktales and Reality. Trans. Peter Tokofsky. Bloomington \& Indianapolis: Indiana University Press.

-. 2008[2002]. 'And they are Still Living Happily Ever After'. Anthropology, Cultural History and Interpretation of Fairy Tales. Trans. Paul Washbourne. Burlington, Vermont: Department of German and Russian, University of Vermont.

Rölleke, Heinz. 1985. 'Wo das Wünschen noch geholfen hat': Gesammelte Aufsätze zu den Kinder- und Hausmärchen der Brüder Grimm. Bonn: Bouvier.

-. 1986[1975]. "The 'Utterly Hessian' Fairy Tales by 'Old Marie': The End of a Myth”. Trans. Ruth Bottigheimer. In Ruth Bottigheimer (ed.), Fairy Tales and Society. Illusion, Allusion, and Paradigm. Philadelphia: University of Pennsylvania Press, pp. 287-300.

-. 1988[1986]. "New Results of Research on Grimms' Fairy Tales". Trans. James M. McGlathery. In James M. McGlathery (ed.), The Brothers Grimm and the Folktale. Urbana \& Chicago: University of Illinois Press, pp. 101-111.

-. 1993. "Kinder- und Hausmärchen”. In Kurt Ranke (ed.), Enzyklopädie des Märchens. Band 7, Lieferung 4/5. Berlin \& New York: Walter de Gruyter, pp. 1278-1297.

-. 2000. Die Märchen der Brüder Grimm: Quellen und Studien. Gesammelte Aufsätze. Trier: Wissenschaftlicher Verlag Trier.

—. 2002. "Grimms Märchen Die Bremer Stadtmusikanten. Herkunft und Textgenese”. Fabula 43(3/4) pp. 295-300. https://doi.org/10.1515/fabl.2002.034.

Ronen, Ruth. 1986. "Space in Fiction". Poetics Today 7(3), pp. 421-438. https://doi.org/10.2307/1772504.

- 1994. Possible Worlds in Literary Theory. Cambridge: Cambridge University Press.

-. 1997. "Description, Narrative and Representation". Narrative 5(3), pp. 274-286.

Rosenberg, Bruce A. 1991. Folklore and Literature: Rival Siblings. Knoxville: The University of Tennessee Press.

Rosowski, Susan J. 1987. "Willa Cather and the Fatality of Place: O Pioneers!, My Antonia, and A Lost Lady". In William E. Mallory and Paul Simpson-Housley (eds.), Geography and Literature. A Meeting of the Disciplines. Syracuse \& New York: Syracuse University Press, pp. 81-94.

Roston, Murray. 2011. The Comic Mode in English Literature. From the Middle Ages to Today. London $\&$ New York: Continuum.

Rowe, Karen E. 1979. "Feminism and Fairy Tales". Women's Studies 6(3), pp. 237-257. https://doi.org/10.1080/00497878.1979.9978487.

Rowland, Susan. 2002. Jung: A Feminist Revision. Cambridge: Polity Press.

Rozin, Paul. 2003. "Meat". In Solomon H. Katz (ed.), Encyclopedia of Food and Culture. Vol. 2. Food Production to Nuts. New York: Charles Scribner's Sons, pp. 466-471.

Rudd, David. 2009. "Animal and object stories”. In Matthew O. Grenby and Andrea Immel (eds.), The Cambridge Companion to Children's Literature. Cambridge: Cambridge University Press, pp. 242-257.

Ryan, Marie-Laure. 1985. "The Modal Structure of Narrative Universes". Poetics Today 6(4), pp. 717755. https://doi.org/10.2307/1771963. 
-. 1991. Possible Worlds, Artificial Intelligence, and Narrative Theory. Bloomington: Indiana University Press.

-. 2003. "Cognitive Maps and the Construction of Narrative Space". In David Herman (ed.), Narrative Theory and the Cognitive Sciences. Standford: CLSI, pp. 214-242.

- . 2006. "From Parallel Universes to Possible Worlds: Ontological Pluralism in Physics, Narratology and Narrative." Poetics Today 27(4), pp. 633-74. https://doi.org/10.1215/03335372-2006-006.

—. 2014[2009]. "Space". In Peter Hühn, Jan Christoph Meister, John Pier, and Wolf Schmid (eds.), Handbook of Narratology. Volume 2. 2nd edn. Berlin/Boston: De Gruyter, pp. 796-811.

-. 2017. "Narrative". In Imre Szeman, Sarah Blacker, and Justin Sully, (eds.), A Companion to Critical and Cultural Theory. London: John Wiley \& Sons Ltd., pp. 517-530.

Ryan, Marie-Laure, Kenneth Foote, and Maoz Azaryahu. 2016. Narrating Space / Spatializing Narrative. Where Narrative Theory and Geography Meet. Columbus: Ohio State University Press.

Ryan, Marie-Laure, and Jan-Noël Thon (eds.). 2014. Storyworlds across Media. Toward a MediaConscious Narratology. Lincoln \& London: University of Nebraska Press.

Sale, Roger. 1978. Fairy Tales and After. From Snow White to E. B. White. Cambridge, Massachussetts \& London: Harvard University Press.

Sävborg, Daniel. 2018. "The Icelander and the Trolls - The Importance of Place". In Ülo Valk and Daniel Sävborg (eds.), Storied and Supernatural Places. Studies in Spatial and Social Dimensions of Folklore and Sagas. Helsinki: Finnish Literature Society, pp. 194-205.

Schanoes, Veronica L. 2014. Fairy Tales, Myth, and Psychoanalytic Theory. Feminism and Retelling the Tale. Farnham, Surrey: Ashgate.

Schmiesing, Ann. 2014. Disability, Deformity, and Disease in the Grimms' Fairy Tales. Detroit: Wayne State University Press.

-. 2016. "Blackness in the Grimms' Fairy Tales". Marvels \& Tales 30(2), pp. 210-233. https://doi.org/10.13110/marvelstales.30.2.0210.

Scholes, Robert E. 1975. Structural Fabulation: An Essay on Fiction of the Future. Notre Dame \& London: University of Notre Dame Press.

Schönle, Andreas. 2000. Authenticity and Fiction in the Russian Literary Journey, 1790-1840. Cambridge, Massachussetts \& London: Harvard University Press.

Schoon Eberly, Susan. 1988. "Fairies and the Folklore of Disability: Changelings, Hybrids and the Solitary Fairy”. Folklore 99(1), pp. 58-77. https://doi.org/10.1080/0015587X.1988.9716425.

Schwartz, Emanuel K. 1956. "A Psychoanalytic Study of the Fairy Tale". The American Journal of Psychotherapy 10(4), pp. 740-762. https://doi.org/10.1176/appi.psychotherapy.1956.10.4.740.

Scott, Carole. 1996. "Magical Dress: Clothing and Transformation in Folk Tales". Children's Literature Association Quarterly 21(4), pp. 151-157. https://doi.org/10.1353/chq.0.1186.

Seifert, Lewis C. 1996. Fairy Tales, Sexuality, and Gender in France, 1690-1715. Nostalgic Utopias. Cambridge: Cambridge University Press.

-. 2015a. "Introduction: Queer(ing) Fairy Tales". Marvels \& Tales 29(1), pp. 15-20. https://doi.org/10.13110/marvelstales.29.1.0015.

—. 2015b. "Queer Time in Charles Perrault's 'Sleeping Beauty”. Marvels \& Tales 29(1), pp. 21-41. https://doi.org/10.13110/marvelstales.29.1.0021.

Seto, Ken-ichi. 1999. "Distinguishing Metonymy from Synecdoche". In Klaus-Uwe Panther and Günter Radden (eds.), Metonymy in Language and Thought. Amsterdam, Philadelphia: John Benjamins Publishing Company, pp. 91-120.

Short, Sue. 2015. Fairy Tale and Film: Old Tales with a New Spin. Basingstoke: Palgrave Macmillan. Shrek. 2001. Andrew Adamson and Vicky Jenson (dir.). USA: DreamWorks Animation

Silva, Sara Graça da, and Jamshid J. Tehrani. 2016. "Comparative phylogenetic analyses uncover the ancient roots of Indo-European folktales". Royal Society Open Science 3(1), pp. 1-11. https://doi.org/10.1098/rsos.150645.

Sinfield, Alan. 1994. Cultural Politics - Queer Reading. Philadelphia: University of Pennsylvania Press. 
Smith, Kevin Paul. 2007. The Postmodern Fairy Tale. Folkloric Intertexts in Contemporary Fiction. New York: Palgrave Macmillan.

Soja, Edward W. 1989. Postmodern Geographies. The Reassertion of Space in Critical Social Theory. London \& New York: Verso.

-. 1996. Thirdspace. Journeys to Los Angeles and Other Real-and-Imagined Places. Cambridge, MA: Blackwell Publishers.

Solis, Santiago. 2007. "Snow White and the Seven 'Dwarfs' - Queercripped". Hypatia 22(1), pp. 114 131. https://doi.org/10.1111/j.1527-2001.2007.tb01152.x.

Soriano, Marc. 1969. "From Tales of Warning to Formulettes: The Oral Tradition in French Children's Literature". Trans. Julia Block Frey. Yale French Studies 43, pp. 24-43. https://doi.org/10.2307/2929634.

Stallcup, Jackie E. 2012. "Discomfort and Delight: The Role of Humour in Roald Dahl's Works for Children". In Ann Alston and Catherine Butler (eds.), Roald Dahl. Basingstoke: Palgrave Macmillan, pp. 31-50.

Stanzel, Franz Karl. 1984[1979]. A Theory of Narrative. Cambridge, London, New York, New Rochelle, Melbourne, \& Sydney: Cambridge University Press.

Steinby, Liisa, and Tintti Klapuri (eds.). 2013. Bakhtin and his Others: (Inter)subjectivity, Chronotope, Dialogism. London, New York, \& Delhi: Anthem Press.

Sternberg, Meir. 1981. "Ordering the Unordered: Time, Space, and Descriptive Coherence". Yale French Studies (61), pp. 60-88. https://doi.org/10.2307/2929877.

Stock, Brian. 1996[1990]. Listening for the Text. On the Uses of the Past. Philadelphia: University of Pennsylvania Press.

Stone, Kay. 1975. "Things Walt Disney Never Told Us". The Journal of American Folklore 88(347), pp. 42-50. https://doi.org/10.2307/539184.

-. 1985. "The Misuses of Enchantment: Controversies on the Significance of Fairy Tales". In Rosan A. Jordan and Susan J. Kalcik (eds.), Women's Folklore, Women's Culture. Philadelphia: University of Pennsylvania Press, pp. 125-145.

—. 1986. "Feminist Approaches to the Interpretation of Fairy Tales". In Ruth Bottigheimer (ed.), Fairy Tales and Society. Illusion, Allusion, and Paradigm. Philadelphia: University of Pennsylvania Press, pp. 229-236.

Sundmark, Björn. 2014. “'A Serious Game': Mapping Moominland”. The Lion and the Unicorn 38(2), pp. 162-181. https://doi.org/10.1353/uni.2014.0022.

Suvin, Darko. 2010[1979]. Metamorfoze znanstvene fantastike. O poetici i povijest jednog književnog žanra. Zagreb: Profil multimedija.

Sydow, Carl Wilhelm von. 1948[1934]. "Geography and Folk-tale Ecotypes". In Laurits Bødker (ed.), Selected Papers on Folklore. Copenhagen: Rosenkilde and Bagger, pp. 44-55.

—. 1948. "On the Spread of Tradition". In Laurits Bødker (ed.), Selected Papers on Folklore. Copenhagen: Rosenkilde and Bagger, pp. 11-43.

—. 1948[1938]. "Popular Prose Traditions and their Classification". In Laurits Bødker (ed.), Selected Papers on Folklore. Copenhagen: Rosenkilde and Bagger, pp. 127-145.

Šundalić, Zlata. 2010. "Konotacije puta u Vili slovinki”. In Nikola Batušić et al. (eds.), Dani Hvarskoga kazališta. Sv. 36. Putovanje, lutanje i bijeg u hrvatskoj književnosti. Split: Hrvatska akademija znanosti i umjetnosti, Književni krug, pp. 88-138.

Tally Jr, Robert T. (ed.). 2014. Literary Cartographies: Spatiality, Representation, and Narrative. London \& New York: Palgrave Macmillan.

Tangherlini, Timothy R. 1994. Interpreting Legend. Danish Storytellers and their Repertoires. New York \& London: Garland Publishing, Inc.

—. 2010. "Legendary Performances. Folklore, Repertoire and Mapping". Ethnologia Europaea 40(2), pp. 103-115.

Tatar, Maria. 1992. Off with their Heads!: Fairy Tales and the Culture of Childhood. Princeton: Princeton University Press. 
-. 2003[1987]. The Hard Facts of Grimms' Fairy Tales. 2nd edn. Princeton \& Oxford: Princeton University Press.

- (ed.). 2004a. The Annotated Brothers Grimm. London \& New York: W. W. Norton \& Company.

-. 2004b. Secrets beyond the Door. The Story of Bluebeard and his Wives. Princeton \& Oxford: Princeton University Press.

Tehrani, Jamshid J. 2013. "The Phylogeny of Little Red Riding Hood". PLOS ONE 8(11), p. e78871. https://doi.org/10.1371/journal.pone.0078871.

Teverson, Andrew. 2013. Fairy Tale. London \& New York: Routledge.

- (ed.). 2019. The Fairy Tale World. Oxford \& New York: Routledge.

Thoene, Marcel. 2016. Toward Diversity and Emancipation. (Re-)Narrating Space in the Contemporary American Novel. Bielefeld: transcript Verlag.

Thomas, Joyce.1986. "Woods and Castles, Towers and Huts: Aspects of Setting in the Fairy Tale". Children's Literature in Education 17(2), pp. 126-134. https://doi.org/10.1007/BF01139900.

Thompson, Stith. 1977[1946]. The Folktale. 2nd edn. Berkeley, Los Angeles \& London: University of California Press.

Timpe, Eugene F. 1971. "The Spatial Dimension: A Stylistic Typology”. In Joseph Strelka (ed.), Patterns of Literary Style. University Park \& London: The Pennsylvania State University Press, pp. 179-197.

Todorov, Tzvetan. 1975[1970]. The Fantastic. A Structural Approach to a Literary Genre. Trans. Richard Howard. Ithaca: Cornell University Press.

Tolkien, J. R. R. 1965[1947]. “On Fairy-stories”. In J. R. R. Tolkien, Tree and Leaf. Boston: Houghton Mifflin, pp. 3-81.

Toolan, Michael. 2001[1988]. Narrative. A Critical Linguistic Introduction. 2nd edn. London \& New York: Routledge.

Treese, Steven A. 2018. History and Measurement of the Base and Derived Units. Cham: Springer.

Tsagalis, Christos. 2012. From Listeners to Viewers: Space in the Iliad. Washington: Center for Hellenic Studies.

Tuan, Yi-Fu. 2008[1977]. Space and Place. The Perspective of Experience. 6th edn. London \& Minneapolis: University of Minnesota Press.

Turner, Kay. 2012. "Playing with Fire: Transgression as Truth in Grimms' 'Frau Trude'”. In Pauline Greenhill and Kay Turner (eds.), Transgressive Tales: Queering the Grimms. Detroit: Wayne State University Press, pp. 245-274.

-. 2015. "At Home in the Realm of Enchantment: The Queer Enticements of the Grimms' 'Frau Holle"”. Marvels \& Tales 29(1), pp. 42-63. https://doi.org/10.13110/marvelstales.29.1.0042.

Turner, Kay, and Pauline Greenhill. 2012a. "Introduction: Once upon a Queer Time". In Kay Turner and Pauline Greenhill (eds.), Transgressive Tales: Queering the Grimms. Detroit: Wayne State University Press, pp. 1-24.

- (eds.). 2012b. Transgressive Tales: Queering the Grimms. Detroit: Wayne State University Press.

Uspensky, Boris. 1983[1970]. A Poetics of Composition. The Structure of the Artistic Text and Typology of a Compositional Form. Trans. Valentina Zavarin and Susan Wittig. Berkeley, Los Angeles, \& London: University of California Press.

Uther, Hans-Jörg. 1981. Behinderte in populären Erzählungen. Studien zur historischen und vergleichenden Erzählforschung. Berlin: De Gruyter.

- (ed.). 2004. The Types of International Folktales. A Classification and Bibliography Based on the System of Antti Aarne and Stith Thompson. Part I. Animal Tales, Tales of Magic, Religious Tales, and Realistic Tales, with an Introduction. Part II. Tales of the Stupid Ogre, Anecdotes and Jokes, and Formula Tales. Part III. Appendices. FF Communications 284-286. Helsinki: Academia scientarium Fennica.

—. 2013[2008]. Handbuch zu den Kinder- und Hausmärchen der Brüder Grimm. Enststehung Wirkung - Interpretation. 2nd edn. Berlin \& Boston: Walter de Gruyter. 
Valk, Ülo, and Daniel Sävborg. 2018a. "Place-Lore, Liminal Storyworld and Ontology of the Supernatural. An Introduction". In Ülo Valk and Daniel Sävborg (eds.), Storied and Supernatural Places. Studies in Spatial and Social Dimensions of Folklore and Sagas. Helsinki: Finnish Literature Society, pp. 7-24.

- (eds.). 2018b. Storied and Supernatural Places: Studies in Spatial and Social Dimensions of Folklore and Sagas. Helsinki: Finnish Literature Society.

Van Coillie, Jan. 2014. "'Oh, how hard it is to play the translator's game': Translating Orality in the Grimms' 'Rumpelstiltskin"”. Marvels \& Tales 28(2), pp. 346-366. https://doi.org/10.13110/marvelstales.28.2.0346.

Vermette, Rosalie. 1987. "Terrae Incantatae: The Symbolic Geography of Twelfth-Century Arthurian Romance". In William E. Mallory and Paul Simpson-Housley (eds.), Geography and Literature. A Meeting of the Disciplines. Syracuse \& New York: Syracuse University Press, pp. 145-160.

Wachsler, Arthur A. 1975. "The 'Elaborate Ruse': A Motif of Deception in Early Celtic Historical Variants of the Journey to the Other World". Journal of the Folklore Institute 12(1), pp. 29-46. https://doi.org/10.2307/3813968.

Walls, Jerry L. 2002. Heaven. The Logic of Eternal Joy. Oxford: Oxford University Press.

Walsh, Richard. 2017. "Beyond Fictional Worlds: Narrative and Spatial Cognition". In Per Krogh Hansen, John Pier, Philippe Roussin, and Wolf Schmid (eds.), Emerging Vectors of Narratology. Berlin \& Boston: Walter de Gruyter, pp. 461-478. https://doi.org/10.1515/9783110555158-022.

Ward, Donald. 1991. "On the Genre Morphology of Legendry: Belief Story versus Belief Legend". Western Folklore 50(3), pp. 296-303. https://doi.org/10.2307/1499880.

Warf, Barney. 2010. "Relative/Relational Space". In Barney Warf (ed.), Encyclopedia of Geography. Thousand Oaks: SAGE Publications, Inc., pp. 2403-2405.

Warner, Marina. 1995. From the Beast to the Blonde. On Fairy Tales and their Tellers. London: Vintage.

-. 2014. Once upon a Time: A Short History of Fairy Tale. Oxford: Oxford University Press.

Weber, Eugen. 1981. "Fairies and Hard Facts: The Reality of Folktales". Journal of the History of Ideas 42(1), pp. 93-113. https://doi.org/10.2307/2709419.

Wehse, Rainer. 2001. "Parodie". In Kurt Ranke (ed.). Enzyklopädie des Märchens. Band 10, Lieferung 2. Berlin \& New York: Walter de Gruyter, pp. 576-587.

Weingart, Scott, and Jeana Jorgensen. 2013. "Computational Analysis of the Body in European Fairy Tales". Literary and Linguistic Computing 28(3), pp. 404-416. https://doi.org/10.1093/llc/fqs015.

Wellek, René, and Warren, Austin. 1956[1948]. Theory of Literature. 3rd edn. New York: Harcourt, Brace \& World, Inc.

Wesselski, Albert. 1931. Versuch einer Theorie des Märchens. Reichengerg in Bayern: Sudetendeutscher Verlag Franz Kraus.

Whitehead, Claire. 2008. "The Fantastic: An Enduring Literary Mode. Introduction". Forum for Modern Language Studies 44(4), pp. 353-362. https://doi.org/10.1093/fmls/cqn057.

Wienker-Piepho, Sabine. 1993. "Kettenmärchen”. In Kurt Ranke (ed.), Enzyklopädie des Märchens. Band 7, Lieferung 4/5. Berlin \& New York: Walter de Gruyter, pp. 1194-1201.

—. 2001. "Märchenschlösser. Überlegungen zur Faszination eines Anachronismus". Märchenspiegel. Zeitschrift für internationale Märchenforschung und Märchenpflege 12(3), pp. 94-100.

—. 2019. "Märchenschlösser - Dwelling an nicht verortbaren Orten?". Fabula 60(1-2), pp. 5-19. https://doi.org/10.1515/fabula-2019-0002.

Wilkie-Stibbs, Christine. 2004[1996]. "Childhood, Didacticism and the Gendering of British Children's Literature". In Peter Hunt (ed.), International Companion Encyclopedia of Children's Literature. Volume 1. 2nd edn. New York \& London: Routledge, pp. 352-361.

Willingham, Bill. 2002-2015. Fables. New York: DC Comics Vertigo.

Wright, Will. 1975. Sixguns and Society. A Structural Study of the Western. Berkeley \& Los Angeles: University of California Press. 
Yamato, Lori. 2017. "Surgical Humanization in H. C. Andersen's 'The Little Mermaid"”. Marvels \& Tales 31(2), pp. 295-312. https://doi.org/10.13110/marvelstales.31.2.0295.

Yenika-Agbaw, Vivian. 2011. "Reading Disability in Children's Literature: Hans Christian Andersen's Tales". Journal of Literary \& Cultural Disability Studies 5(1), pp. 91-108. https://doi.org/10.3828/jlcds.2011.6.

Yocom, Margaret R. 2012. “'But who are You Really?': Ambiguous Bodies and Ambiguous Pronouns in 'Allerleirauh"'. In Kay Turner and Pauline Greenhill (eds.), Transgressive Tales: Queering the Grimms. Detroit: Wayne State University Press, pp. 91-118.

Yolen, Jane. 1998. "Preface". In Kathleen Ragan (ed.), Fearless Girls, Wise Women, and Beloved Sisters. Heroines in Folktales from Around the World. New York \& London: W. W. Norton \& Company, pp. xvii-xix.

Young, Katharine Galloway. 1987. Taleworlds and Storyrealms. The Phenomenology of Narrative. Dordrecht: Martinus Nijhoff.

Zahorski, Kenneth J., and Robert H. Boyer. 1982. "The Secondary Worlds of High Fantasy". In Roger C. Schlobin (ed.), The Aesthetics of Fantasy Literature and Art. Notre Dame: University of Notre Dame Press, pp. 56-81.

Zaradija Kiš, Antonija. 2012. "Nezahvalni sin ili čovjek s krastačkom na licu". Narodna umjetnost: Croatian journal of ethnology and folklore research 49(2), pp. 115-138.

Zgorzelski, Andrzej. 1984. "On Differentiating Fantastic Fiction: Some Supragenological Distinctions in Literature". Poetics Today 5(2), pp. 299-307. https://doi.org/10.2307/1771934.

Zink, Suzana. 2018. Virginia Woolf's Rooms and the Spaces of Modernity. New York: Palgrave Macmillan.

Zinn, Emily R. 2000. "Rediscovery of the Magical: On Fairy Tales, Feminism, and the New South Africa". Modern Fiction Studies 46(1), pp. 246-269. https://doi.org/10.1353/mfs.2000.0015.

Ziolkowski, Jan M. 2010. "Straparola and the Fairy Tale: Between Literary and Oral Traditions". Journal of American Folklore 123(490), pp. 377-397. https://doi.org/10.1353/jaf.2010.0002.

Zipes, Jack. 2002[1979]. Breaking the Magic Spell: Radical Theories of Folk and Fairy Tales. Revised and expanded edn. Lexington: University Press of Kentucky.

—. 2002[1988]. The Brothers Grimm. From Enchanted Forests to the Modern World. 2nd edn. New York: Palgrave Macmillan.

—. 2002[2000]a. "Introduction: Towards a Definition of the Literary Fairy Tale". In Jack Zipes (ed.), The Oxford Companion to Fairy Tales: The Western Fairy Tale Tradition from Medieval to Modern. Oxford: Oxford University Press, pp. xv-xxxii.

- (ed.). 2002[2000]b. The Oxford Companion to Fairy Tales: The Western Fairy Tale Tradition from Medieval to Modern. Oxford: Oxford University Press.

—. 2003[1987]. "Once there were Two Brothers Named Grimm". In: Jacob and Wilhelm Grimm. The Complete Fairy Tales of the Brothers Grimm, 3rd edn. New York, Toronto, London, Sydney, \& Auckland: Bantam Books, pp. xxiii-xxxvi.

-. 2005. Hans Christian Andersen: The Misunderstood Storyteller. New York \& Oxford: Routledge.

-. 2006[1983]. Fairy Tales and the Art of Subversion. The Classical Genre for Children and the Process of Civilization. 2nd edn. New York \& London: Routledge.

-. 2006. Why Fairy Tales Stick: The Evolution and Relevance of a Genre. New York \& London: Routledge.

-. 2011. The Enchanted Screen. The Unknown History of Fairy-Tale Films. New York: Routledge.

- . 2012. The Irresistible Fairy Tale. The Cultural and Social History of a Genre. Princeton: Princeton University Press.

-. 2015. Grimm Legacies. The Magic Spell of the Grimms' Folk and Fairy Tales. Princeton: Princeton University Press.

Zlatar, Manuela. 2007. Novo čitanje bajke: arhetipsko, divlje, žensko. Zagreb: Centar za ženske studije.

Zoran, Gabriel. 1984. "Towards a Theory of Space in Narrative". Poetics Today 5(2), pp. 309-335. https://doi.org/10.2307/1771935. 


\section{Appendices}

\section{Appendix 1.}

\section{Research corpus}

Although the surname Grimm is traditionally associated with fairy tales, possibly owing to the fact that translations of their collection are often published under the title Grimms' Fairy Tales (or even Grimm's [sic!] Fairy Tales; Ashliman 2017), the Kinder- und Hausmärchen is a generically diverse collection. Bottigheimer, for instance, describes it as "a mixed lot of animal tales; tales of origins [...]; warning tales [...], folk tales whose characters usually end up where they started" and "even religious tales" (2009: 8). Linda Dégh identifies the following genres among the Grimms' texts (1979: 90-91):

magic tales, about the miraculous career of lowly heroes and heroines; romantic love and adventure stories (novellas); Christian legends and miracle stories; didactic exempla; explanatory and origin legends; ghost stories; legends about evil spirits, witches, and the malevolent dead; fables; chain and catch tales; lying tales; and humorous anecdotes about numbskulls, tricksters, and adulterers.

Later in the same text, the author also mentions animal tales, religious legends, and scare or warning tales (ibid.: 91). In the introduction to his translation of the complete KHM, Zipes describes the collection as consisting of magic fairy tales, as well as "unusual fables, legends, anecdotes, jokes, and religious tales" (2003[1987]: xxxiii). In addition to fairy tales, Tatar identifies "cautionary tales, legends, ghost stories, jests, and animal fables liberally sprinkled throughout the Grimms' collection" (2003[1987]: 62). Acknowledging the possibility of placing the same narrative in different genre categories, Uther identifies the following genres within the KHM: aetiologies, exempla, fables, parables, religious tales, (Schwank) legends, tall tales, nonsense tales, catch tales, riddle (Schwank) tales, cautionary tales, Schwank tales, animal (Schwank) tales, and fairy tales (2013[2008]: 478-479).

While the generic diversity of the collection has been widely acknowledged by scholars, there is a distinct lack of consensus on which genres it features (fairy/magic tales, animal tales, and folk tales and/or jests being the most frequently mentioned; see previous paragraph), and which of the tales belongs to which genre category. 
With some exceptions, such as Uther (2013[2008]), scholars rarely engage in extensive classifications of the KHM corpus, and even those who do come up with different results. For instance, Uther identifies a total of 86 fairy tales (not counting the texts that were included in the collection at some point during its publication history but were omitted from the final edition) in the final edition of the KHM (2013[2008]: 479). In contrast, Albert Wesselski claims that "barely sixty" of the Grimms' tales can be classified as "true" fairy tales (1931: 97).

This lack of consensus is by no means unique to the Grimms' collection, but is, to some extent, a feature of genre in general. Writing about folklore studies, Dundes famously stated that "thus far in the illustrious history of the discipline, not so much as one genre has been completely defined" (1980[1964]: 21). The elusiveness of (literary, folklore) genre definitions stems at least partly from the flexibility and mutability of genre, the numerous theoretical perspectives from which it has been studied, and the fact that different criteria (e.g. structure, content, function) point to different possibilities of genre classification (Cohen 1991: 88, 94). For example, if we consider the structure of a tale such as the Grimms' "The Wolf and the Seven Young Kids", we might (following Propp's functions) be inclined to label it a fairy tale; however, based on its content (primarily characters) or function, it might also be categorised as an animal tale or a cautionary tale, respectively (cf. Hameršak 2012). Additional difficulties regarding the descriptions of individual genre categories arise from their limited and highly mutable nature. The former problem stems from the fact that a given genre category is not built on descriptions of each of its members, but rather on a limited number of select examples (Todorov 1975[1970]: 3-4). As such, it presents a scholarly construct, an ideal type which exists in theory but not necessarily in practice (cf. Honko 1969). Furthermore, the dynamic and flexible genre categories often change across narrating communities, and literary and historical periods, as different elements become highlighted as their defining features (Pavel 2003: 201). A frequently cited example is that of elegy, a poetic genre that was initially defined according to formal criteria (i.e. verse and meter) and later based on its thematic preoccupation with sorrow and regret (Wellek \& Warren 1956[1948]: 241-42). ${ }^{95}$ Despite its problems, genre remains a highly useful concept and "crucial interpretative tool" (Pavel 2003: 202) which allows us to classify (large) corpora of texts and highlight their individual characteristics by including them within specific categories.

Given the variety of genres featured in the Grimms' collection, the first step in studying space in fairy tales was identifying which among their texts belong in that

95 For more detailed discussions on genre theory within literary and folklore studies, see, among others, Beebee (1994), Duff (2000), Frow (2006), Honko (1989), Koski, Frog, \& Savolainen (2016). 
genre category. In the absence of a definitive classification of the Grimms' tales, the attempt to place these narratives within appropriate genre categories began with the Aarne-Thompson-Uther (ATU) Index of International Tale Types (Uther 2004). Bringing together and organising a large number of folktales, and thus providing researchers all over the world with a common reference point, the value of the ATU Index can hardly be overstated. However, as many scholars have pointed out (cf. Dundes 1997; Jason 2000; Propp 1968[1928]), its classification system is by no means perfect. Multi-episodic or tale types encompassing several motifs are especially problematic as each episode/motif presents a potential classification criterion: for instance, a tale featuring both a stupid ogre and a magic object may be classified within both tales of the stupid ogre (ATU 1000-1199) and magic tales (ATU 300-749). Thus, the ultimate decision regarding the classification of such a tale stems from "the subjective evaluation of the classifier", rather than objective criteria (Dundes 1962: 98). ${ }^{96}$ The ATU classification for individual tales was taken from Uther's Handbuch zu den Kinder- und Hausmärchen (2013[2008]). It should be noted that not all of the Grimms' tales have been classified in the ATU Index (e.g. "The Rose", "The Blessed Virgin's Little Glass", "The Hazel Branch").

This initial ATU classification, which identifies 106 KHM tales (full tales or at least one episode/motif in a multi-tale type) as belonging to tales of magic, was further modified on the basis of our working definition of the fairy tale (presented in the Introduction), which draws on Lüthi (1986[1947]) and Bottigheimer (2009) in its emphasis on the necessity of interaction between the non-magical and the magical, magical intervention as a key prerequisite for the protagonist's success, and the acceptance of the magical as part of everyday life. The content-based focus on magic led to the re-classification of some tales included in other ATU categories into the category of the fairy tale. For instance, "The Goose Girl at the Spring" is included in the ATU category of realistic tales or novelle (ATU 850-999), because it contains the "Love Like Salt" motif (ATU 923). However, the presence of magical characters (the old woman) and events (tears turning into pearls and other magical transformations) which are given precedence in the present classification challenges its designation as a realistic narrative, providing the basis for its inclusion among fairy tales. On the other hand, this research does not consider some of the KHM tales classified among tales of magic in the ATU Index to be fairy tales. This is especially true of tales such as "The Messengers of Death" and "Godfather Death", which end with the death of the protagonist. While it does not consider the happy ending to be

96 The composer of the original Index, Antti Aarne, was well aware of this problem and suggested that in the case of multiple possibilities of classification precedence be given to the element which is "of greatest significance to the action" (1910: viii). However, choosing which element has the greatest significance is again left up to the researcher. 
an obligatory part of the fairy-tale genre (this is why tales such as "The Fisherman and His Wife", which Bottigheimer counts among folk tales due to its lack of the proverbial happily-ever-after, are classified as fairy tales in our corpus; 2009: 8), this research does treat the portrayal of death as an important distinguishing feature between fairy tales, in which death is typically a temporary and reversible occurrence (the antagonists being the exception), and legends, in which - as Röhrich succinctly puts it - the protagonist "dies, and remains dead" (2008[2002]: 91). Therefore, the fairy tale can have a protagonist who ends up losing everything they have accumulated in the course of the story (such as the titular fisherman and his wife) but not one who dies in the end (such as the characters in "Godfather Death", "The Messengers of Death", or "Mother Trudy").

While using the ATU Index as a starting point and relying on its own working definition of the fairy tale as its focal genre, this research also consulted a number of scholarly sources in preparing a preliminary genre classification of the KHM tales. The works of Bottigheimer (1987), Röhrich (1991[1979]; 2008[2002]), Tatar (1992; 2003[1987]; 2004a), Zipes (2002[1988]), Wesselski (1931), and especially Uther (2013[2008]) all proved useful, as did the Grimms' own notes to their tales (2007[1822]). It should be noted that the following genre classification is by no means meant to be definitive, but is intended as a preliminary division of the research corpus, one that is likely to change once the category of narrative space has been taken into consideration. Furthermore, this research acknowledges that the corpus could have been organised differently if different criteria (such as structure or function) were selected as the starting point for genre classification.

Judging solely by the ordinal numbers attached to each tale, the final edition of the Grimms' collection includes 210 tales. However, some of the titles actually encompass multiple texts: "The Elves" (KHM 39) and "Tales About Toads" (KHM 105) both encompass three tales, while KHM 151 appears as two differently entitled texts: "The Three Lazy Sons" (KHM 151, ATU 1950) and "The Twelve Lazy Servants" (KHM 151a, ATU 1950). ${ }^{97}$ The present research considers each of these texts separately, which means the overall research corpus consists of a total of 215 generically diverse texts. The list below divides these texts into the following genre categories: fairy tales (which constitute the primary research corpus), animal tales, didactic tales, aetiological tales, folk tales, formula tales, legends, religious tales, and humorous or Schwank tales (the secondary research corpus, listed alphabetically). The KHM number, English and German titles, and ATU tale type (where applicable) are provided for each tale. Some tales proved more resistant to categorisation than

97 While "Little Red Cap" and "The Wedding of Mrs. Fox" also include two tales, in both cases the second narrative is a continuation of the main story rather than a tale in its own right, and is therefore not considered separately. 
others. For example, at first glance, tales such as "The Wren" and "The Flounder" seem like clear-cut animal tales, but since they also provide explanations for the origins, behaviour, or physical traits of individual animal species, they might also be considered aetiological legends. Similarly, a story such as "The Peasant and the Devil", with a plot which revolves around an underdog peasant outwitting the devil, appears to be a Schwank tale; however, the appearance of the devil (and supernatural elements in general) points to alternative classification possibilities, such as legends or religious tales. Is "The Peasant and the Devil", then, a humorous tale about the devil, or a religious tale with humorous elements? Such "hybrid" cases (Lüthi 1986[1947]: 107), as well as the cases in which the present classification differs from the ATU Index, are accompanied by explanatory notes.

\section{Primary research corpus: fairy tales}

KHM 1. "The Frog King, or Iron Heinrich" (Der Froschkönig oder der eiserne Heinrich), ATU 440. The Frog King Or Iron Henry.

KHM 3. "The Virgin Mary's Child” (Marienkind), ATU 710. Our Lady's Child.

KHM 6. "Faithful Johannes" (Der treue Johannes), ATU 516. Faithful John.

KHM 9. "The Twelve Brothers" (Die zwölf Brüder), ATU 451. The Maiden Who Seeks Her Brothers.

KHM 11. "Brother and Sister" (Brüderchen und Schwesterchen), ATU 450. Little Brother and Little Sister.

KHM 12. "Rapunzel" (Rapunzel), ATU 310. The Maiden in the Tower.

KHM 13. "The Three Little Gnomes in the Forest" (Die drei Männlein im Walde), ATU 403. The Black and the White Bride.

KHM 14. "The Three Spinners" (Die drei Spinnerinnen), ATU 501. The Three Old Spinning Women.

KHM 15. "Hansel and Gretel" (Hänsel und Gretel), ATU 327A. Hansel and Gretel. KHM 16. "The Three Snake Leaves" (Die drei Schlangenblätter), ATU 612. The Three Snake-Leaves.

KHM 17. "The White Snake” (Die weiße Schlange), ATU 673. The White Serpent's Flesh + ATU 554. The Grateful Animals.

KHM 19. "The Fisherman and His Wife" (Von dem Fischer un syner Fru), ATU 555. The Fisherman and His Wife.

KHM 21. "Cinderella" (Aschenputtel), ATU 510A. Cinderella.

KHM 24. "Mother Holle" (Frau Holle), ATU 480. The Kind and the Unkind Girls. KHM 25. "The Seven Ravens" (Die sieben Raben), ATU 451. The Maiden Who Seeks Her Brothers. 
KHM 29. "The Devil With the Three Golden Hairs" (Der Teufel mit den drei goldenen Haaren), ATU 461. Three Hairs from the Devil's Beard + ATU 930. The Prophecy.

KHM 31. "The Maiden Without Hands" (Das Mädchen ohne Hände), ATU 706. The Maiden without Hands + ATU 930. The Prophecy.

KHM 33. "The Three Languages" (Die drei Sprachen), ATU 517. The Boy Who Understands the Language of Birds, ATU 725. Prophecy of Future Sovereignty + ATU 671. The Three Languages.

KHM 36. "The Magic Table, the Golden Donkey, and the Club in the Sack" (Tischchendeckdich, Goldesel und Knüppel aus dem Sack), ATU 563. The Table, the Donkey and the Stick + ATU 212. The Lying Goat.

- fairy tale framed by an animal tale (story of the talking goat); contains

Schwank elements (physical punishment of the wrong-doers); Uther describes it as a Schwank tale (2013[2008]: 87).

KHM 39 (i). "The Elves" (Die Wichtelmänner), Mot. F333. Fairy grateful to human midwife, F405.11. House spirit leaves when gift of clothing is left for it, F451.5.10.9. Ausgelohnt, F480. House-spirits.

- not classified in the ATU Index; based on the story's positive portrayal of the elves (which differs from their portrayal in legends, something the Grimms themselves also note; 2007[1822]: 928) and their departure, as well as the happy ending which brings about beneficial changes for both the shoemaker and his little helpers, Uther considers this to be a fairy tale (2013[2008]: 95); this research acknowledges the presence of some elements of the legend in this tale - most notably the elves themselves, who only appear at midnight, as well as the amazement the shoemaker feels upon their discovery - but ultimately views the narrative as a fairy tale, primarily because of the appearance of the magical characters and their role in changing the material conditions of the human characters.

KHM 46. "Fitcher's Bird" (Fitchers Vogel), ATU 311. Rescue by the Sister.

KHM 47. "The Juniper Tree" (Von dem Machandelboom), ATU 720. The Juniper Tree.

KHM 49. “The Six Swans” (Die sechs Schwäne), ATU 451. The Maiden Who Seeks Her Brothers.

KHM 50. "Brier Rose” (Dornröschen), ATU 410. Sleeping Beauty.

KHM 51. "Foundling" (Fundevogel), ATU 313. The Magic Flight.

KHM 53. "Snow White" (Sneewittchen), ATU 709. Snow White.

KHM 54. "The Knapsack, the Hat, and the Horn" (Der Ranzen, das Hütlein und das Hörnlein), ATU 569. The Knapsack, the Hat and the Horn.

KHM 55. "Rumpelstiltskin" (Rumpelstilzchen), ATU 500. The Name of the Supernatural Helper. 
KHM 56. "Sweetheart Roland" (Der Liebste Roland), ATU 1119. The Ogre Kills His Mother (Wife) + ATU 313. Magic Flight + ATU 407. The Girl as Flower. KHM 57. "The Golden Bird" (Der goldene Vogel), ATU 550. Bird, Horse and Princess.

KHM 60. "The Two Brothers" (Die zwei Brüder), ATU 567. The Magic Bird-Heart + ATU 300. The Dragon-Slayer + ATU 303. The Twins or Blood-Brothers.

KHM 62. "The Queen Bee” (Die Bienenkönigin), ATU 554. The Grateful Animals. KHM 63. "The Three Feathers" (Die drei Federn), ATU 402. The Animal Bride.

KHM 64. "The Golden Goose" (Die goldene Gans), ATU 571. "All Stick Together" + ATU 513B. The Land and Water Ship.

KHM 65. "All Fur” (Allerleirauh), ATU 510B. Peau d'Asne.

KHM 66. "The Hare's Bride" (Häsichenbraut), cf. ATU 311. Rescue by the Sister. KHM 67. "The Twelve Huntsmen" (Die zwölf Jäger), ATU 884. The Forsaken Fiancée: Service as Menial + ATU 313. Magic Flight.

- includes two ATU tale types which belong to different categories: realistic tales and magic tales; the tale is here classified as a fairy tale because of the presence of a magical talking lion, the appearance of which is accepted as an everyday occurrence; Uther also considers it a fairy tale (2013[2008]: 156).

KHM 68. "The Thief and His Master" (De Gaudeif un sien Meester), ATU 325. The Magician and His Pupil.

KHM 69. "Jorinda and Joringel" (Jorinde und Joringel), ATU 405. Jorinde and Joringel.

KHM 71. "How Six Made Their Way in the World" (Sechse kommen durch die ganze Welt), ATU 513A. Six Go through the Whole World.

KHM 76. "The Pink Flower" (Die Nelke), ATU 652. The Prince Whose Wishes Always Come True.

KHM 79. "The Water Nixie" (Die Wassernixe), ATU 313. The Magic Flight.

KHM 85. "The Golden Children” (Die Goldkinder), ATU 303. The Twins or BloodBrothers.

KHM 88. "The Singing, Springing Lark" (Das singende springende Löweneckerchen), ATU 425A. The Animal as Bridegroom.

KHM 89. "The Goose Girl” (Die Gänsemagd), ATU 533. The Speaking Horsehead. KHM 90. "The Young Giant” (Der junge Riese), ATU 650A. Strong John.

KHM 91. "The Gnome" (Dat Erdmänneken), ATU 301. The Three Stolen Princesses.

KHM 92. "The King of the Golden Mountain" (Der König vom goldenen Berge), ATU 400. The Man on a Quest for His Lost Wife + cf. ATU 810. The Snares of the Evil One + ATU 518. Men Fight over Magic Objects + ATU 974. The Homecoming Husband. 
KHM 93. "The Raven" (Die Rabe), ATU 400. The Man on a Quest for His Lost Wife + ATU 518. Men Fight over Magic Objects.

KHM 96. "The Three Little Birds" (De drei Vügelkens), ATU 707. The Three Golden Children.

KHM 97. "The Water of Life" (Das Wasser des Lebens), ATU 551. Water of Life.

KHM 99. "The Spirit in the Glass Bottle" (Der Geist im Glas), ATU 331. The Spirit in the Bottle.

KHM 100. "The Devil's Sooty Brother" (Des Teufels rußiger Bruder), ATU 475. The Man as Heater of Hell's Kettle.

KHM 101. "Bearskin” (Der Bärenhäuter), ATU 361. Bear-Skin.

KHM 103. "The Sweet Porridge” (Der süße Brei), ATU 565. The Magic Mill.

KHM 106. "The Poor Miller's Apprentice and the Cat" (Der arme Müllerbursch und das Kätzchen), ATU 402. The Animal Bride.

KHM 107. "The Two Travelers" (Die beiden Wanderer), ATU 613. The Two Travelers.

KHM 108. "Hans My Hedgehog” (Hans mein Igel), ATU 441. Hans My Hedgehog.

KHM 110. "The Jew in the Thornbush" (Der Jude im Dorn), ATU 592. The Dance among Thorns.

KHM 111. "The Expert Huntsman” (Der gelernte Jäger), ATU 304. The Dangerous Night-Watch.

KHM 113. "The Two Kings' Children” (De beiden Künigeskinner), ATU 313. Magic Flight.

KHM 116. "The Blue Light" (Das blaue Licht), ATU 562. The Spirit in the Blue Light.

KHM 120. "The Three Journeymen" (Die drei Handwerksburschen), ATU 360. Bargain of the Three Brothers with the Devil, ATU 1697. "We Three; For Money".

KHM 121. "The Prince Who Feared Nothing” (Der Königssohn, der sich vor nichts fürchtet), ATU 590. The Faithless Mother.

KHM 122. "The Lettuce Donkey” (Der Krautesel), ATU 567. The Magic Bird-Heart + ATU 566. The Three Magic Objects and the Wonderful Fruits.

KHM 123. "The Old Woman in the Forest" (Die Alte im Wald), ATU 442. The Old Woman in the Forest.

KHM 125. "The Devil and His Grandmother" (Der Teufel und seine Großmutter), ATU 812. The Devil's Riddle.

- classified under religious tales in the ATU Index; this research considers it a fairy tale because of the interaction between the magical and the non-magical, acceptance of the magical, and the fact that the three protagonists succeed thanks to magical assistance (advice from the old lady, the devil/dragon's magical gifts); building on the importance of riddles for 
the plot, Uther describes it as a tale about riddles (Rätselmärchen; 2013[2008]: 264), while Röhrich views it as a fairy tale with Schwank elements - most notably the titular devil's grandmother (1991[1979]: 53).

KHM 126. "Faithful Ferdinand and Unfaithful Ferdinand" (Ferenand getrü un Ferenand ungetrü), ATU 531. The Clever Horse.

KHM 127. "The Iron Stove" (Der Eisenofen), ATU 425. The Search for the Lost Husband, 425A. The Animal as Bridegroom.

KHM 129. "The Four Skillful Brothers" (Die vier kunstreichen Brüder), ATU 653.

The Four Skillful Brothers.

KHM 130. "One-Eye, Two-Eyes, and Three-Eyes" (Einäuglein, Zweiäuglein und Dreiäuglein), ATU 511. One-Eye, Two-Eyes, Three-Eyes.

KHM 133. "The Worn-out Dancing Shoes" (Die zertanzten Schuhe), ATU 306. The Danced-out Shoes.

KHM 134. "The Six Servants" (Die sechs Diener), ATU 513A. Six Go through the Whole World + ATU 900. King Thrushbeard.

KHM 135. "The White Bride and the Black Bride" (Die weiße und die schwarze Braut), ATU 403. The Black and the White Bride.

KHM 136. "Iron Hans" (Der Eisenhans), ATU 314. Goldener (cf. ATU 502. The Wild Man).

KHM 137. "The Three Black Princesses" (De drei schwatten Prinzessinnen), cf. ATU 400. The Man on a Quest for His Lost Wife.

KHM 141. "The Little Lamb and the Little Fish" (Das Lämmchen und Fischchen), ATU 450. Little Brother and Little Sister.

KHM 142. "Simelei Mountain" (Simeliberg), ATU 954. The Forty Thieves.

- classified under realistic tales in the ATU Index; this research considers it a fairy tale, primarily because it features magical occurrences (magic words, magic cave), which enable the protagonist to improve his material situation; Uther also lists it among the KHM fairy tales (2013[2008]: 285).

KHM 144. "The Donkey" (Das Eselein), ATU 430. The Donkey.

KHM 160. "A Tale With a Riddle" (Rätselmärchen), cf. ATU 407. The Girl as Flower.

KHM 161. "Snow White and Rose Red" (Schneeweißchen und Rosenrot), ATU 426.

The Two Girls, the Bear, and the Dwarf.

KHM 163. "The Glass Coffin" (Der gläserne Sarg), cf. ATU 410. Sleeping Beauty + ATU 552. The Girls Who Married Animals.

KHM 165. "The Griffin" (Der Vogel Greif), ATU 610. The Healing Fruits (+ ATU 570. The Rabbit-Herd) + ATU 513B. The Land and Water Ship + ATU 461. Three Hairs from the Devil's Beard.

KHM 166. "Strong Hans" (Der starke Hans), ATU 650A. Strong John + ATU 301. The Three Stolen Princesses. 
KHM 169. "The House in the Forest" (Das Waldhaus), ATU 431. The House in the Forest.

KHM 179. "The Goose Girl at the Spring” (Die Gänsehirtin am Brunnen), ATU 923. Love Like Salt.

- included among realistic tales in the ATU Index; however, most researchers, such as Uther (2013[2008]: 350), Röhrich (2008[2002]: 36), and Tatar (2003[1987]: 93), consider it a fairy tale; this research also views it as a fairy tale, in view of the presence of magical characters (the old woman) and events (pearls for tears, magical transformations, etc.).

KHM 181. "The Nixie in the Pond" (Die Nixe im Teich), ATU 316. The Nix of the Mill-Pond + ATU 313. The Magic Flight.

KHM 182. "The Gifts of the Little Folk" (Die Geschenke des kleinen Volkes), ATU 503. The Gifts of the Little People.

KHM 186. "The True Bride" (Die wahre Braut), cf. ATU 313. The Magic Flight.

KHM 188. "Spindle, Shuttle, and Needle" (Spindel, Weberschiffchen und Nadel), ATU 585. Spindle, Shuttle, and Needle.

KHM 191. "The Little Hamster From the Water" (Das Meerhäschen), ATU 329.

Hiding from the Princess.

KHM 193. "The Drummer" (Der Trommler), ATU 400. The Man on a Quest for His Lost Wife + ATU 518. Men Fight over Magic Objects + ATU 313. The Magic Flight.

KHM 196. "Old Rinkrank" (Oll Rinkrank), cf. ATU 530. The Princess on the Glass Mountain + cf. ATU 1159. The Ogre Caught in the Cleft.

KHM 197. "The Crystal Ball” (Die Kristallkugel), ATU 552. The Girls Who Married Animals + ATU 518. Men Fight over Magic Objects + ATU 302. The Ogre's (Devil's) Heart in the Egg.

KHM 199. "The Boots of Buffalo Leather" (Der Stiefel von Büffelleder), ATU 952.

The King and the Soldier.

- included among realistic tales in the ATU Index; this research views it as a fairy tale in view of the (unexplained) magical abilities of the soldier (making the robbers freeze), which ultimately lead to the improvement of his social and material status; other researchers - for instance, Uther - classify it as a Schwank tale (2013[2008]: 383).

KHM 201 (KL ${ }^{98}$ 1). "Saint Joseph in the Forest" (Der heilige Joseph im Walde), ATU 480. The Kind and the Unkind Girls.

- despite its inclusion among the children's religious tales (Kinderlegenden) section of the KHM, the story follows the fairy-tale pattern 
similar to that found in "Mother Holle" or "The Three Little Gnomes in the Forest" (cf. Grimm 2007[1822]: 1108), but assigns the role of magical helper to a religious figure; because of its inclusion among the Kinderlegenden, many researchers view it as a religious tale (Uther 2013[2008]: 386) or saint's legend (Röhrich 1991[1979]: 36); Tatar highlights the story's didactic potential by pointing out that it "combines exemplary story with cautionary tale to produce the classic reward-and-punishment pattern" (1992: 86).

\section{Secondary research corpus: other genres in the KHM}

\section{i. Animal tales}

KHM 2. "The Companionship of the Cat and the Mouse" (Katze und Maus in Gesellschaft), ATU 15. The Theft of Food by Playing Godfather.

KHM 8. "The Marvelous Minstrel" (Der wunderliche Spielmann), ATU 38. Claw in Split Tree, ATU 151. A Man Teaches a Wild Animal to Play the Fiddle.

KHM 10. "Riffraff' (Das Lumpengesindel), ATU 210. Rooster, Hen, Duck, Pin, and Needle on a Journey.

KHM 23. "The Mouse, the Bird, and the Sausage" (Von dem Mäuschen, Vögelchen und der Bratwurst), ATU 85. The Mouse, the Bird, and the Sausage.

KHM 27. "The Bremen Town Musicians" (Die Bremer Stadtmusikanten), ATU 130. The Animals in Night Quarters.

KHM 38. "The Wedding of Mrs. Fox" (Die Hochzeit der Frau Füchsin), ATU 65. The She-Fox's Suitors.

KHM 41. "Herr Korbes" (Herr Korbes), ATU 210. Rooster, Hen, Duck, Pin, and Needle on a Journey.

KHM 48. "Old Sultan" (Der alte Sultan), ATU 101. The Old Dog as Rescuer of the Child (Sheep) + ATU 103. War between Wild Animals and Domestic Animals. KHM 58. "The Dog and the Sparrow" (Der Hund und der Sperling), ATU 248. The Dog and the Sparrow, ATU 223. The Bird and the Jackal.

KHM 72. "The Wolf and the Man" (Der Wolf und der Mensch), ATU 157. Animals Learn to Fear Men.

KHM 73. "The Wolf and the Fox" (Der Wolf und der Fuchs), ATU 41. The Wolf Overeats in the Cellar + ATU 122. Animal Loses His Prey Because His Victim Can Escape by False Plea.

KHM 74. "The Fox and His Cousin" (Der Fuchs und die Frau Gevatterin), ATU 3*. The Wolf Supplies Food for the Fox + cf. ATU 37. The Fox as Nursemaid for the Mother Bear + ATU 4. Sick Animal Carries the Healthy One.

KHM 75. "The Fox and the Cat" (Der Fuchs und die Katze), ATU 105. The Cat's Only Trick. 
KHM 102. "The Wren and the Bear" (Der Zaunkönig und der Bär), ATU 222. War between Birds (Insects) and Quadrupeds.

KHM 132. "The Fox and the Horse" (Der Fuchs und das Pferd), ATU 47A. The Fox Hangs Onto the Horse's Tail.

KHM 187. "The Hare and the Hedgehog" (Der Hase und der Igel), ATU 275C. The Race between Hare and Hedgehog.

KHM 190. "The Crumbs on the Table" (Die Brosamen auf dem Tisch), ATU 106. Animals' Conversation.

\section{ii. Didactic tales}

KHM 5. "The Wolf and the Seven Young Kids" (Der Wolf und die sieben jungen Geißlein), ATU 123. The Wolf and the Kids.

- cautionary animal tale; classified under animal tales in the ATU Index; Uther (2013[2008]: 11) and Bottigheimer (1987: 188) consider it an animal tale, while Röhrich points out it is also a warning (cautionary) tale (2008[2002]: 157); for Tatar, this is "a cautionary fable, designed to convey a lesson to children" (2004a: 29).

KHM 26. "Little Red Cap" (Rotkäppchen), ATU 333. Little Red Riding Hood.

- cautionary (warning) tale; classified among tales of magic in the ATU Index; Uther (2013[2008]: 63) and Röhrich (2008[2002]: 112, 169) list it among the KHM fairy tales, while Tatar notes that it "has become possibly the most famous cautionary tale of all times" (1992: 35).

KHM 43. "Mother Trudy" (Frau Trude), ATU 334. Household of the Witch.

- cautionary tale (cf. Tatar 2003[1987]: 192); classified among tales of magic in the ATU Index; Uther also lists it among cautionary or scare tales (2013[2008]: 101), while Röhrich describes it as a fairy tale of warning (2008[2002]: 31).

KHM 78. "The Old Man and His Grandson" (Der alte Großvater und der Enkel), ATU 980(1). The Ungrateful Son.

- a realistic exemplum; classified under realistic tales in the ATU Index; Uther describes it as a parable (2013[2008]: 174), Röhrich as a didactic fairy tale (2008[2002]: 82).

KHM 117. "The Stubborn Child" (Das eigensinnige Kind), ATU 760**. The Obstinate Child.

- cautionary tale (cf. Tatar 2003[1987]: 192); listed among religious tales in the ATU Index; Uther describes it as a didactic, warning legend (2013[2008]: 251).

KHM 145. "The Ungrateful Son” (Der undankbare Sohn), ATU 980D. Meat Springs as a Toad on the Face of an Ungrateful Son. 
- exemplum with supernatural elements; listed among religious tales in the ATU Index; Uther also describes it as an exemplum (2013[2008]: 290), while Röhrich sees it as both a legend (2008[2002]: 91) and a didactic (warning) fairy tale (ibid.: 31).

KHM 153. "The Star Coins” (Die Sterntaler), ATU 779H*. Star Money.

- exemplary tale (cf. Tatar 1992: 43); classified as a religious tale in the ATU Index; Uther describes it as a religious legend (2013[2008]: 304), while Röhrich notes it "seems like a saint's legend" (1991[1956]: 38).

\section{iii. Aetiological tales}

KHM 18. "The Straw, the Coal, and the Bean" (Strohhalm, Kohle und Bohne), ATU 295. The Bean (Mouse), the Straw, and the Coal + Mot. A2793.1. Why bean has black stripe.

- humorous animal tale with an aetiological ending (explaining why beans have a black seam; cf. Uther 2013[2008]: 41); classified as an animal tale in the ATU Index; due to its humorous elements, Wesselski considers it a parody of the nature legend (1931: 96).

KHM 147. "The Rejuvenated Little Old Man" (Das junggeglühte Männlein), ATU

753. Christ and the Smith.

- humorous religious legend with an aetiological ending (explaining the origins of apes); classified as a religious tale in the ATU Index; Uther describes it as a Schwank tale with religious element and an aetiological ending (2013[2008]: 294-295); for Tatar, this is a tale about violence with an aetiological coda (1992: 167), a folk tale with pronounced violent and comical elements (2003[1987]: 184).

KHM 148. "The Animals of the Lord and the Devil" (Des Herrn und des Teufels Getier), ATU 773. Contest of Creation between God and the Devil + ATU 1184. The Last Leaf.

- religious aetiological tale (explaining the origin of goats) with Schwank elements (outwitting the devil); the ATU Index describes it as a combination of two tale types: one belonging to religious tales, the other to tales of the stupid ogre; Uther describes it as a Schwank tale with aetiological elements (2013[2008]: 296), while other scholars highlight its aetiological aspects (Bottigheimer 1987: 146; Röhrich 1991[1956]: 28).

KHM 171. "The Wren" (Der Zaunkönig), ATU 221A. Test: Who Can Fly Highest?, ATU 221B. Test: Who Can Go Deepest in Earth? + cf. Mot. A2571. How animals received their names, Mot. A2494.13. Enmities of birds, Mot. A2494.13.4. Enmity between owl and mouse, Mot. A2332.6.6. Why owl is blind by day, Mot. A2491.2. Why owl avoids daylight. 
- animal aetiological tale (explaining how different bird species developed their properties); featured among animal tales in the ATU Index; Uther describes it as a humorous animal aetiology (2013[2008]: 335).

KHM 172. "The Flounder" (Die Scholle), ATU 250A. The Flounder's Crooked Mouth.

- animal aetiological tale (explaining the origin of the flounder's crooked mouth); featured among animal tales in the ATU Index; Uther describes it as an aetiological legend (2013[2008]: 339), while Röhrich discusses it alongside both animal tales (2008[2002]: 150) and aetiological narratives (1991[1956]: 28).

KHM 173. "The Bittern and the Hoopoe" (Rohrdommel und Wiedehopf), ATU 236*.

Miscellaneous Tales with Imitation of Bird Sounds.

- animal aetiological tale (explaining the origin of bird sounds); featured among animal tales in the ATU Index; Uther describes it as an aetiological legend (2013[2008]: 341).

KHM 175. "The Moon" (Der Mond), Mot. A758. Theft of the moon + Mot.

A755.4.2. Moon stolen and divided into quarters + Mot. A755.2. Moon's phases caused by watcher's death.

- aetiological legend explaining how the Moon came to hang from the sky; not classified in the ATU Index; Uther describes it as a tale which combines grotesque (dividing the moon) and aetiological elements with the Schwank tale (2013[2008]: 344); Bottigheimer points out that the tale's genre "is artificially determined by the outcome", making it an aetiology (1987: 148).

KHM 176. "The Life Span" (Die Lebenszeit), ATU 173. Human and Animal Life Spans are Readjusted.

- aetiological legend explaining the duration of human and animal lives; classified as an animal tale in the ATU Index; Uther describes it as a parable with an aetiological ending, which can also be labelled as a humorous religious tale (2013[2008]: 346).

KHM 180. "Eve's Unequal Children" (Die ungleichen Kinder Evas), ATU 758. The Various Children of Eve.

- religious aetiological tale; classified as a religious tale in the ATU Index; Uther describes it as a combination of a didactic religious tale (teaching about the need to accept God's wisdom) and aetiological legend (2013[2008]: 352), while Röhrich considers it an aetiology (2008: 168), specifically, an aetiological saint's legend (1991[1956]: 36); Bottigheimer labels it as both an aetiology (1987: 146) and a Christian tale (ibid.: 182).

KHM 194. "The Ear of Corn” (Die Kornähre), ATU 779G*. Crime against Grain. 
- religious tale with an aetiological coda (explaining the appearance of the plant); classified as a religious tale in the ATU Index; for Uther, this is both an aetiological and warning legend (teaching a lesson about the negative consequences of ingratitude; 2013 [2008]: 376); other scholars highlight the tale's aetiological properties (Bottigheimer 1987: 146-147; Röhrich 1991[1956]: 29).

KHM 202 (KL 2). "The Twelve Apostles" (Die zwölf Apostel), ATU 766. The Seven Sleepers + Mot. V232. Angel as helper + Mot. V292. The Apostles of Christ.

- sacred aetiological legend explaining the origin of the twelve apostles; classified as a religious tale in the ATU Index; the Grimms consider it to be a legend (2007[1822]: 1108), while Röhrich defines it more closely as a saint's legend (1991[1956]: 36); for Uther, this is a legend with an aetiological ending (2013[2008]: 387).

KHM 207 (KL 7). “The Blessed Virgin's Little Glass” (Muttergottesgläschen), Mot. A2655. Origin of bindweed (convolvulus sepium) + Mot. A2711.4.3. Plant receives name because of service to Virgin Mary.

- sacred aetiological legend explaining how the titular plant got its name; not classified in the ATU Index; Uther describes it as a combination of a religious legend and aetiology (2013[2008]: 393); similarly, Röhrich considers it to be an aetiological saint's legend (1991[1956]: 36).

KHM 210 (KL 10). "The Hazel Branch" (Die Haselrute), Mot. A2711.4.1. Hazel gives Virgin Mary shelter + Mot. D1402.10.2. Rod from magic hazel-tree kills snake immediately.

- sacred aetiological tale explaining the origin of the protective properties of the hazel branch; not classified in the ATU Index; Uther describes it as a combination of a legend about the Virgin Mary and a plant aetiology (2013[2008]: 397); Röhrich proposes a similar classification as an aetiological saint's legend (1991[1956]: 36).

\section{iv. Folk tales (realistic tales/novelle)}

KHM 22. "The Riddle" (Das Rätsel), ATU 851. The Princess Who Cannot Solve the Riddle.

KHM 40. "The Robber Bridegroom" (Der Räuberbräutigam), ATU 955. Robber Bridegroom.

KHM 52. "King Thrushbeard" (König Drosselbart), ATU 900. King Thrushbeard. KHM 84. "Hans Gets Married" (Hans heiratet), ATU 859(3) + ATU 859(2). The Penniless Bridegroom Pretends to Wealth.

KHM 94. "The Clever Farmer's Daughter" (Die kluge Bauerntochter), ATU 875. The Clever Farmgirl. 
KHM 115. "The Bright Sun Will Bring It to Light" (Die klare Sonne bringt's an den Tag), ATU 960. The Sun Brings All to Light.

KHM 150. "The Old Beggar Woman" (Die alte Bettelfrau), Mot. N300. Unlucky accidents + Mot. S20. Cruel children and grandchildren.

- not classified in the ATU Index; Uther describes it as a scare tale (2013[2008]: 299); here it is classified as a folk tale primarily because of the absence of magical or otherwise supernatural elements.

KHM 152. "The Little Shepherd Boy" (Das Hirtenbüblein), ATU 922. The Shepherd Substituting for the Clergyman Answers the King's Questions.

KHM 170. "Sharing Joys and Sorrows" (Lieb und Leid teilen), cf. Mot. T256. The quarrelsome wife or husband, J1280. Repartee with ruler (judge, etc.), J1290. Reduction ad absurdum of question or proposal.

- not classified in the ATU Index; Uther describes it as a Schwank tale about married couples (2013[2008]: 334); this classification highlights the realistic aspects of the narrative.

KHM 198. "Maid Maleen” (Jungfrau Maleen), ATU 870. The Princess Confined in the Mound.

- although both Uther (2013[2008]: 381) and Röhrich (2008: 112, 128) classify it as a fairy tale, this research considers the narrative to be a folk tale, as the basic premise of a girl surviving lengthy captivity in a tower is implausible rather than supernatural, especially since neither the survival nor the later regaining of the fiance's affections are the result of magical intervention.

\section{v. Formula tales}

KHM 30. "The Louse and the Flea" (Läuschen und Flöhchen), ATU 2022. The Death of the Little Hen.

KHM 80. "The Death of the Hen" (Von dem Tode des Hühnchens), ATU 2021. The Rooster and the Hen.

KHM 86. "The Fox and the Geese" (Der Fuchs und die Gänse), ATU 227. Geese Ask for Respite for Prayer.

- endless animal tale; classified as an animal tale in the ATU Index; Uther describes it as an animal tale in the manner of a catch tale (Uther 2013[2008]: 189), while the Grimms highlight its status as a catch tale (2007[1822]: 1006).

KHM 131. "Pretty Katrinelya and Pif Paf Poltree" (Die schöne Katrinelje und Pif Paf Poltrie), ATU 2019. Pif Paf Poltrie.

KHM 140. "The Domestic Servants" (Das Hausgesinde), ATU 1940. The Extraordinary Names. 
- classified under anecdotes and jokes in the ATU Index; Uther also identifies it as a Schwank tale (2013[2008]: 283), while Röhrich describes it as a humorous cumulative tale (Röhrich 1991[1956]: 145); this research considers it to be a formula (cumulative) tale due to its absence of a traditional plot, as well as the repetition and accumulation of nonsensical names and toponyms (Kujundžić 2012: 189).

KHM 184. "The Nail" (Der Nagel), ATU 2039. The Horseshoe Nail.

KHM 200. "The Golden Key” (Der goldene Schlüssel), ATU 2260. The Golden Key.

\section{vi. Legends}

KHM 28. "The Singing Bone" (Der singende Knochen), ATU 780. The Singing Bone.

- classified under religious tales in the ATU Index; this research views it as a fairy-tale religious legend as it contains elements of fairy tales (magic helper, impossible task, success of the virtuous younger sibling), legends (death of the protagonist is permanent), and religious tales (existence of a soul, wrong-doing is exposed from beyond the grave); while Uther lists it among the KHM fairy tales (2013[2008]: 73), Röhrich sees it as "a cross between a tale of magic and a moralistic, didactic legend" (1991[1979]: 46), a story that is "clearly not an ordinary magic tale, but rather a legend or a crime story or a didactic story" (2008[2002]: 91); the Grimms also highlight elements of the legend in the tale (2007[1822]: 916).

KHM 39 (ii). "The Elves" (Die Wichtelmänner), ATU 476** Midwife in the Underworld + Mot. D2011. Years thought days.

- classified among tales of magic in the ATU Index; Uther considers it to be a fairy tale based on legend motifs, a fairy-tale version of the legend about the service of the midwife/godmother underground (2013[2008]: 95); this research considers it to be a legend, largely because time in the elf world operates under different conditions from how does in the human world (three days with the elves translates to seven years in the human world).

KHM 39 (iii). "The Elves" (Die Wichtelmänner), Mot. F321.1. Changeling + Mot. D512.1. Transformation when one expresses astonishment at smith drawing water in an egg-shell + Mot. F321.1.1.1. Changeling betrays his age when his wonder is excited + Mot. F321.1.1.5. Changeling calculates his age by the age of the forest + Mot. F451.5.17.1. Invisible dwarfs at christening feast made to speak by brewing beer in egg-shell + Mot. F481.4. Brewing in eggshell to drive away cobold.

- not classified in the ATU Index; for Uther, this is (largely in view of the happy ending) a fairy tale based on legend motifs (the changeling; 
2013[2008]: 96), while Röhrich considers it a legend (2008[2002]: 31); this research also sees it as a legend, primarily because of the negative portrayal of elves (stealing children from cradles) and the presence of the changeling motif.

KHM 42. "The Godfather" (Der Herr Gevatter), ATU 332. Godfather Death + ATU 334. Household of the Witch.

- classified under tales of magic in the ATU Index; Uther describes it as a scare tale (2013[2008]: 99); like Röhrich (1991[1956]: 48), this research considers it a legend (despite the presence of some fairy-tale elements, such as receiving magical assistance which enables the protagonist to earn money), largely because of the terrifying nature of the godfather and the events taking place at his house, all of which frighten the protagonist.

KHM 44. "Godfather Death" (Der Gevatter Tod), ATU 332. Godfather Death.

- classified under tales of magic in the ATU Index; while Uther also considers it a fairy tale (2013[2008]: 103), Tatar notes several ways in which the narrative departs from fairy-tale convention, such as the bleak ending for the protagonist (2004a: 194-195) and his ambition becoming his downfall (ibid.: 198, n.4); for Röhrich, this is both a didactic tale and a fairy tale (2008[2002]: 92, 166); elsewhere, Röhrich notes that the depiction of Death as a helper rather than a threatening figure suggests that this is a folk tale rather than a legend (1991[1956]: 22); this research views the tale as a legend, mostly because it ends with the death of the protagonist.

KHM 105 (i). "Tales About Toads" (Märchen von der Unke), ATU 285. The Child and the Snake, ATU 285A. The Man and the Wounded Snake (= Mot. B391.1. Child feeds snake from its milk-bottle + Mot. B765.6. Snake eats milk and bread with child).

- classified as an animal tale in the ATU Index; Uther points out that, in view of its negative outcome, the tale is closer to a legend than a fairy tale (2013[2008]: 226); this research takes it cue from Wesselski (1931: 94-95) and Röhrich (2008[2002]: 91), both of whom categorise the tale as a legend, primarily because of the death of the main characters.

KHM 105 (ii). "Tales About Toads" (Märchen von der Unke), ATU 672. The Serpent's Crown.

- classified under tales of magic in the ATU Index; according to Uther, the death of the animal makes this tale "legend-like" (2013[2008]: 226); like the Grimms (2007[1822]: 1047), Wesselski (1931: 94-95), and Röhrich (2008[2002]: 31), this research considers the narrative to be a legend, because of the death of the toad, as well as the presence of a belief regarding the gift-giving behaviour of toads. 
KHM 154. "The Stolen Pennies" (Der gestohlene Heller), Mot. E423.1.1. Revenant as dog + Mot. E411. Dead cannot rest because of sin + Mot. E451. Ghost finds rest when certain thing happens + Mot. E451.5.1. Money must be distributed to beggars so that ghost may be laid.

- not classified in the ATU Index; taking its cue from Uther (2013[2008]: 307), this research considers the narrative to be a warning legend, which discourages stealing and deceptive behaviour, illustrating that such actions will be punished even beyond the grave (appearance of the child ghost).

KHM 177. "The Messengers of Death" (Die Boten des Todes), ATU 335. Death's Messengers.

- classified under tales of magic in the ATU Index; Uther describes it as an exemplum with elements of both the parable and Schwank legend (2013[2008]: 347); this research views it as a religious legend (addressing the inevitability of death, ending with the death of the protagonist) with Schwank elements (Death being overpowered by a giant).

\section{vii. Religious tales}

KHM 87. "The Poor Man and the Rich Man" (Der Arme und der Reiche), ATU 750A. The Three Wishes.

KHM 109. "The Little Shroud” (Das Totenhemdchen), ATU 769. The Child's Grave. KHM 157. "The Sparrow and His Four Children" (Der Sperling und seine vier Kinder), cf. ATU 157B. The Sparrow and His Sons.

- classified as an animal tale in the ATU Index; Uther points out it is a fable interspersed with biblical references (2013[2008]: 311), while Bottigheimer describes it as an animal tale with a strong Christian message (1987: 149); in view of its explicit religious message and intertextual links to the New Testament, this research views the narrative as a parable.

KHM 167. "The Peasant in Heaven" (Das Bürle im Himmel), ATU 802. The Farmer in Heaven.

KHM 195. "The Grave Mound" (Der Grabhügel), ATU 815. The Devil Who Skins a Corpse + ATU 1130. Counting Out Pay.

- a combination of two ATU tale types, one belonging to religious tales, the other to tales of the stupid ogre; Uther classifies it as a Schwank tale (2013[2008]: 377), while for Röhrich "it should be counted as a legend" (2008[2002]: 91); this research views the narrative as a religious tale with Schwank elements, which depicts a rich man who, following a pang of consciousness, changes his ways and is subsequently granted eternal life (his soul is saved from the devil). 
KHM 203 (KL 3). "The Rose" (Die Rose), Mot. Z142.1. White rose the symbol of death.

- not classified in the ATU Index; Tatar describes the narrative as a consolatory tale, intended to provide comfort to those who have lost a loved one (1992: 86); like Uther (2013[2008]: 389), this research considers it to be a religious tale, as it portrays death in a positive light, as the beginning of a blissful afterlife.

KHM 204 (KL 4). "Poverty and Humility Lead to Heaven" (Armut und Demut führen zum Himmel), Mot. K1815.1.1. Pious pilgrim dies unknown in his father's house + Q523.4. Penance: living under stairs as mendicant + Mot. A2611.0.1. Plants from grave of dead person or animal.

- not classified in the ATU Index; for Röhrich, this is a legend (1991[1956]: 36); this research takes its cue from Uther (2013[2008]: 389390 ) and, on the basis of its central lesson about how the titular virtues will be rewarded in the afterlife, categorises the narrative as a religious tale.

KHM 205 (KL 5). "God's Food" (Gottes Speise), ATU 751G*. Bread Turned to Stone.

KHM 206 (KL 6). “The Three Green Twigs” (Die drei grünen Zweige), ATU 756A. The Self-Righteous Hermit.

KHM 208 (KL 8). "The Little Old Lady" (Das alte Mütterchen), ATU 934C. Death Forestalls Evil Fates.

- classified under realistic tales in the ATU Index; Uther considers it a legend (2013[2008]: 394); this research classifies it as a religious tale, in view of the central message about the importance of accepting God's wisdom and omniscience.

KHM 209 (KL 9). "The Heavenly Wedding” (Die himmlische Hochzeit), ATU 767. Food for the Crucifix.

\section{viii. Schwank tales}

KHM 4. "A Tale About the Boy Who Went Forth to Learn What Fear Was" (Märchen von einem, der auszog, das Fürchten zu lernen), ATU 326. The Youth Who Wanted to Learn What Fear Is.

- classified under tales of magic in the ATU Index; while the story follows the typical fairy-tale rags-to-riches plot and depicts magical occurrences, the protagonist's success is not the result of magical assistance (Schwank elements); other classifications also highlight the tale's comical elements: for instance, Uther describes it as a Schwank tale (2013[2008]: 8), while Röhrich contends that, in view of the perceived incompatibility of fairy tales and fear, this tale "in reality does not belong to the genre of the magic 
fairy tale" (2008[2002]: 215), but is "more like a jocular fairy tale", mostly because of its style of "burlesque parody" and ironic title (ibid.: 216); Tatar notes that the narrative lacks traditional "fairy-tale magic that comes in the form of villains, donors, and helpers", and is ultimately "closer to the saga or extended anecdotes" (2004a: 14); on the other hand, Zipes maintains it is a fairy tale, albeit a comical one (2002[1988]: 46).

KHM 7. "The Good Bargain" (Der gute Handel), ATU 1642. The Good Bargain + ATU 1610. Sharing the Reward + ATU 1642A. The Borrowed Coat.

KHM 20. "The Brave Little Tailor" (Das tapfere Schneiderlein), ATU 1640. The Brave Tailor + ATU 1051. Bending a Tree, ATU 1052. Carrying a Tree + ATU 1060. Squeezing the (Supposed) Stone, ATU 1062. Throwing a Stone + ATU 1115. Attempted Murder with a Hatchet.

- classified under anecdotes and jokes in the ATU Index, with elements of tales of the stupid ogre; similar to "A Tale About the Boy Who Went Forth to Learn What Fear Was" (which the ATU classifies as a tale of magic) in that it depicts a rags-to-riches plot and magical occurrences, but features a protagonist who does not enjoy magical assistance; Uther also considers it to be a Schwank tale (2013[2008]: 47), while others, such as Röhrich, maintain it is a tale of magic and as such should be distinguished from "true jests" (1991[1979]: 52).

KHM 32. "Clever Hans" (Der gescheite Hans), ATU 1685. The Foolish Bridegroom + ATU 1696. "What Should I Have Said (Done)?" + Mot. J2129.4. Fool sticks needle in haywagon.

KHM 34. "Clever Else" (Die kluge Else), ATU 1450. Clever Elsie (cf. ATU 1387. The Woman Goes to Get Beer, ATU 1430A. Foolish Plans for the Unborn Child) + ATU 1383. The Woman Does Not Know Herself.

KHM 35. "The Tailor in Heaven" (Der Schneider im Himmel), ATU 800. The Tailor in Heaven.

- classified under religious tales in the ATU Index; taking its cue from Uther (2013[2008]: 85), this research categorises the narrative as a Schwank tale, because it plays with traditional images of heaven (the titular hero gets there by walking, he promises to do all the dirty work there) for comic effect.

KHM 37. "Thumbling" (Daumesdick), ATU 700. Thumbling.

- classified under tales of magic in the ATU Index; similar to, for instance, "The Brave Little Tailor", the tale follows the structure of a multiepisodic fairy tale; however, many typical fairy-tale elements are substituted by elements of the Schwank tale: owing to the protagonist's size, all his "adventures" take place on a miniature scale, lack of a traditional fairy-tale ending (although the tale does end on a positive note), scatological elements, 
lack of magical assistance for the protagonist (who can be seen as a magical character himself), etc.

KHM 45. "Thumbling's Travels" (Daumerlings Wanderschaft), ATU 700. Thumbling.

- fairy-tale Schwank (see note for KHM 37).

KHM 59. "Freddy and Katy" (Der Frieder und das Katherlieschen), ATU 1387. The

Woman Goes to Get Beer + ATU 1541. For the Long Winter (= ATU 1385*.

Learning about Money) + ATU 1291. One Cheese Sent to Bring Back Another

+ ATU 1653. The Robbers under the Tree + cf. ATU 1383. The Woman Does

Not Know Herself + ATU 1791. The Sexton Carries the Clergyman.

KHM 61. "Little Farmer" (Das Bürle), ATU 1535. The Rich and the Poor Farmer +

ATU 1358C. Trickster Discovers Adultery: Food Goes to Husband Instead of Lover + 1358A. Hidden Lover Buys Freedom from Discoverer + ATU 1297*. Jumping into the River after Their Comrade.

KHM 70. "The Three Sons of Fortune" (Die drei Glückskinder), ATU 1650. The

Three Lucky Brothers + ATU 1202. The Dangerous Sickle + ATU 1281. Getting

Rid of the Unknown Animal, ATU 1651. Whittington's Cat + cf. ATU 1282.

House Burned Down to Rid It of Insects.

KHM 77. "Clever Gretel” (Das kluge Gretel), ATU 1741. The Priest's Guest and the Eaten Chickens.

KHM 81. "Brother Lustig" (Bruder Lustig), ATU 785. Lamb's Heart + ATU 330.

The Smith and the Devil.

- religious Schwank; combination of two ATU tale types, one belonging to religious tales, the other to tales of magic; while the Grimms describe it as a legend (2007[1822]: 869, 989), other scholars label the narrative as a Schwank tale (Bottigheimer 1987: 84; Uther 2013[2008]: 178); for Röhrich, this is a farcical saint's legend which combines Schwank and legend elements (1991[1956]: 54); this classification is similar to Röhrich's, as it considers the narrative to be a religious Schwank legend, in view of its humorous portrayal of religious figures (St Peter, devils), occurrences (miracles), and locations (hell).

KHM 82. "Gambling Hans" (De Spielhansl), ATU 330. The Smith and the Devil.

- classified under tales of magic in the ATU Index; the Grimms consider the narrative to be a legend (2007[1822]: 869), while other scholars label it as a Schwank tale (Röhrich 1991[1956]: 53; Uther 2013[2008]: 181); this research classifies it as a religious Schwank legend, which features a central trickster character (he manages to outsmart death) and subverts traditional images of the afterlife.

KHM 83. "Lucky Hans” (Hans im Glück), ATU 1415. Lucky Hans.

KHM 95. “Old Hildebrand” (Der alte Hildebrand), ATU 1360C. Old Hildebrand. 
KHM 98. "Doctor Know-It-All” (Doktor Allwissend), ATU 1641. Doctor Know-All. KHM 104. "The Clever People" (Die klugen Leute), ATU 1385. The Foolish Wife's Security + ATU 1384. The Husband Hunts Three Persons as Stupid as His Wife + ATU 1540. The Student from Paradise (Paris).

KHM 105 (iii). "Tales About Toads" (Märchen von der Unke), Mot. B216.

Knowledge of animal languages + Mot. B212. Animal understands human speech + Mot. B211.7.1. Speaking frog.

- not classified in the ATU Index; the brief tale (almost fragment) consists of a short and somewhat nonsensical exchange between a child and a toad, which includes some repetition; following Uther's classification, this research considers it a nonsense tale (2013[2008]: 226).

KHM 112. "The Fleshing Flail from Heaven" (Der Dreschflegel vom Himmel), ATU 1960A. The Great Ox + 1960G. The Great Tree + ATU 1174. Making a Rope of Sand, ATU 1889. Münchhausen Tales + ATU 1882. The Man Who Fell Out of a Balloon.

KHM 114. "The Clever Little Tailor" (Vom klugen Schneiderlein), ATU 850. The Birthmarks of the Princess + ATU 1061. Biting a Stone to Pieces + ATU 1159. The Ogre Caught in the Cleft.

- combination of three tale types which belong to two different ATU categories: realistic tales and tales of the stupid ogre; Uther describes it as a riddle tale (2013[2008]: 244); this research considers it a fairy-tale Schwank as it features fairy-tale motifs (competing for the hand of the princess, talking animal), but the trickster protagonist succeeds without magical intervention.

KHM 118. "The Three Army Surgeons" (Die drei Feldscherer), ATU 660. The Three Doctors.

- classified under tales of magic in the ATU Index; like Uther (2013[2008]: 252), this research considers it a (fairy-tale) Schwank which combines fairy-tale (magic salve) and comic elements ("fake" body parts, unexpected consequences of the substitution).

KHM 119. "The Seven Swabians" (Die sieben Schwaben), ATU 1321C. Fools are Frightened at the Humming of Bees + ATU 1231. The Attack on the Hare (Crayfish, Toad, Frog) + ATU 1297*. Jumping into the River after Their Comrade.

KHM 124. "The Three Brothers" (Die drei Brüder), ATU 654. The Three Agile Brothers.

- classified under tales of magic in the ATU Index; however, this research finds that the traits of the brothers (and their demonstrations) appear more humorously exaggerated than outright supernatural; Uther also considers it a Schwank tale (2013[2008]: 261). 
KHM 128. "The Lazy Spinner" (Die faule Spinnerin), ATU 1405. The Lazy Spinning Woman.

KHM 138. "Knoist and His Three Sons" (Knoist un sine dre Sühne), ATU 1965. The Disabled Comrades.

KHM 139. "The Maiden From Brakel" (Dat Mäken von Brakel), ATU 1476A. Prayer to Christ Child's Mother.

KHM 143. "Going Traveling" (Up Reisen gohn), ATU 1696. "What Should I Have Said (Done)?"

KHM 146. "The Turnip" (Die Rübe), ATU 1689A. Two Presents for the King + ATU 1535. The Rich and the Poor Farmer.

KHM 149. "The Beam" (Der Hahnenbalken), ATU 987. False Magician Exposed by Clever Girl + ATU 1290. Swimming in the Flax-Field.

- combination of two ATU tale types, one belonging to realistic tales, the other to anecdotes and jokes; both Uther (2013[2008]: 297) and Wesselski (1931: 95-96) consider it a legend; this research categorises the narrative as a Schwank tale because the heroine is outwitted by her opponent and ultimately exposed to ridicule.

KHM 151. "The Three Lazy Sons" (Die drei Faulen), ATU 1950. The Three Lazy Ones.

KHM 151a. "The Twelve Lazy Servants" (Die zwölf faulen Knechte), ATU 1950. The Three Lazy Ones.

KHM 155. "Choosing a Bride" (Die Brautschau), ATU 1452. Thrifty Cutting of Cheese.

KHM 156. "The Leftovers" (Die Schlickerlinge), ATU 1451. The Thrifty Girl.

KHM 158. "The Tale About the Land of Cockaigne" (Das Märchen vom Schlauraffenland), ATU 1935. Topsy Turvy Land + ATU 1930. Schlaraffenland. KHM 159. "A Tall Tale From Ditmarsh" (Das dithmarsische Lügenmärchen), ATU 1935. Topsy Turvy Land + ATU 1930. Schlaraffenland.

KHM 162. "The Clever Servant" (Der kluge Knecht), ATU 1348*. The Boy with Active Imagination.

KHM 164. "Lazy Heinz" (Der faule Heinz), ATU 1430. The Man and His Wife Build Air Castles, 1430A. Foolish Plans for the Unborn Child + cf. ATU 288B*. The Over-Hasty Toad (Beetle).

KHM 168. "Lean Lisa" (Die hagere Liese), ATU 1430. The Man and His Wife Build Air Castles, 1430A. Foolish Plans for the Unborn Child.

KHM 174. "The Owl" (Die Eule), Mot. A2494.13. Enmities of birds + Mot. A2332.6.6. Why owl is blind by day + ATU 1282. House Burned Down to Rid It of Insects. 
KHM 178. "Master Pfriem" (Meister Pfriem), ATU 801. Meister Pfriem (cf. ATU 1248. Tree-Trunks Laid Crosswise on a Sledge + ATU 1180. Catching Water in a Sieve).

- classified under religious tales in the ATU Index, with similarities to tale types from the anecdotes and jokes, and tales of the stupid ogre categories; Uther classifies it as a religious tale (2013[2008]: 348); this research considers it a Schwank tale because of its comic portrayal of heaven as a place where angels are engaged in manual labour.

KHM 183. "The Giant and the Tailor" (Der Riese und der Schneider), ATU 1049. The Heavy Axe + ATU 1053. Shooting Wild Boars + ATU 1051. Bending a Tree.

- classified under tales of the stupid ogre in the ATU Index; Uther considers it a Schwank tale (2013[2008]: 358); this research categorises it as a fairy-tale $S c h w a n k$, in view of the employment of motifs typical of the fairy tale (giant, impossible tasks), but lack of a fairy-tale ending; similarly, Bottigheimer notes this is a Schwank tale which inverts fairy-tale conventions (1987: 34, n. 21).

KHM 185. "The Poor Boy in the Grave" (Der arme Junge im Grab), ATU 1408C. The String of Chickens + ATU 1296B. Doves in the Letter + ATU 1313. The Man Who Wanted to Commit Suicide.

KHM 189. "The Peasant and the Devil" (Der Bauer und der Teufel), ATU 1030. The Crop Division.

KHM 192. "The Master Thief” (Der Meisterdieb), ATU 1525A. Tasks for a Thief + ATU 1740. Candles on the Crayfish + ATU 1737. The Clergyman in the Sack to Heaven. 


\section{Appendix 2. Revised research corpus}

Taking into account the category of narrative space has introduced new insight into individual genre categories identified in our initial classification (Appendix 1), prompting its reconsideration. The introduction of the category of the domain as a possible starting point for distinguishing between genres brought the viability of several genre categories identified in the initial classification into question: specifically, Schwank tales, didactic tales, and aetiological tales. The comparison of individual tales within each category has revealed differences in their spatial structure (primarily, the number and nature of domains featured), which led to the conclusion that these narratives should be considered sub-types of other genres with a clearly established single- or dual-domain structure. In other words, they are seen as modes which may appear across genres (e.g. Schwank fairy tale, religious Schwank, didactic fairy tale, cautionary legend, warning animal tale), rather than autonomous genres.

The lists that follow present a new classification of our corpus, one that takes spatial issues into consideration. The full lists for fairy tales, animal tales, folk tales, formula tales, legends, and religious tales were transferred from Appendix 1, and complemented by narratives classified under didactic tales, aetiological tales, and Schwank tales in that same Appendix. New additions to each genre category and cases which remain problematic as they provide multiple classification possibilities are accompanied by explanatory notes.

\section{Primary research corpus: fairy tales}

KHM 1. "The Frog King, or Iron Heinrich" (Der Froschkönig oder der eiserne Heinrich), ATU 440. The Frog King Or Iron Henry.

KHM 3. "The Virgin Mary’s Child" (Marienkind), ATU 710. Our Lady’s Child.

KHM 4. "A Tale About the Boy Who Went Forth to Learn What Fear Was"

(Märchen von einem, der auszog, das Fürchten zu lernen), ATU 326. The Youth Who Wanted to Learn What Fear Is.

- previously classified as a Schwank tale; fairy-tale parody (Schwank elements) which features the rags-to-riches plot typical of the genre but subverts many of its conventions (e.g. the numbskull protagonist does not rely on magical assistance).

KHM 6. "Faithful Johannes" (Der treue Johannes), ATU 516. Faithful John.

KHM 9. "The Twelve Brothers" (Die zwölf Brüder), ATU 451. The Maiden Who Seeks Her Brothers.

KHM 11. "Brother and Sister" (Brüderchen und Schwesterchen), ATU 450. Little Brother and Little Sister.

KHM 12. "Rapunzel” (Rapunzel), ATU 310. The Maiden in the Tower. 
KHM 13. "The Three Little Gnomes in the Forest" (Die drei Männlein im Walde), ATU 403. The Black and the White Bride.

KHM 14. "The Three Spinners" (Die drei Spinnerinnen), ATU 501. The Three Old Spinning Women.

KHM 15. "Hansel and Gretel" (Hänsel und Gretel), ATU 327A. Hansel and Gretel. KHM 16. "The Three Snake Leaves" (Die drei Schlangenblätter), ATU 612. The Three Snake-Leaves.

KHM 17. "The White Snake” (Die weiße Schlange), ATU 673. The White Serpent's Flesh + ATU 554. The Grateful Animals.

KHM 19. "The Fisherman and His Wife" (Von dem Fischer un syner Fru), ATU 555. The Fisherman and His Wife.

KHM 20. "The Brave Little Tailor" (Das tapfere Schneiderlein), ATU 1640. The Brave Tailor + ATU 1051. Bending a Tree, ATU 1052. Carrying a Tree + ATU 1060. Squeezing the (Supposed) Stone, ATU 1062. Throwing a Stone + ATU 1115. Attempted Murder with a Hatchet.

- previously classified as a Schwank tale; fairy-tale parody, similar to "A Tale About the Boy Who Went Forth to Learn What Fear Was" in its depiction of a (trickster) protagonist who succeeds by relying on his wit, rather than magical assistance.

KHM 21. "Cinderella" (Aschenputtel), ATU 510A. Cinderella.

KHM 24. "Mother Holle" (Frau Holle), ATU 480. The Kind and the Unkind Girls.

KHM 25. "The Seven Ravens" (Die sieben Raben), ATU 451. The Maiden Who Seeks Her Brothers.

KHM 26. "Little Red Cap" (Rotkäppchen), ATU 333. Little Red Riding Hood.

- previously classified as a didactic tale; cautionary (warning) fairy tale.

KHM 29. "The Devil With the Three Golden Hairs" (Der Teufel mit den drei goldenen Haaren), ATU 461. Three Hairs from the Devil's Beard + ATU 930. The Prophecy.

KHM 31. "The Maiden Without Hands" (Das Mädchen ohne Hände), ATU 706. The Maiden without Hands + ATU 930. The Prophecy.

KHM 33. "The Three Languages" (Die drei Sprachen), ATU 517. The Boy Who Understands the Language of Birds, ATU 725. Prophecy of Future Sovereignty + ATU 671. The Three Languages.

KHM 36. "The Magic Table, the Golden Donkey, and the Club in the Sack" (Tischchendeckdich, Goldesel und Knüppel aus dem Sack), ATU 563. The Table, the Donkey and the Stick + ATU 212. The Lying Goat.

- fairy tale framed by an animal tale (story of the talking goat); contains Schwank elements (physical punishment of the wrong-doers).

KHM 37. "Thumbling” (Daumesdick), ATU 700. Thumbling. 
- previously classified as a Schwank tale; fairy-tale Schwank which parodies the conventions of a traditional adventure fairy tale (e.g. the nature of the "adventures", lack of magical assistance for the protagonist, absence of the antagonist and traditional fairy-tale ending).

KHM 39 (i). "The Elves" (Die Wichtelmänner), Mot. F333. Fairy grateful to human midwife, F405.11. House spirit leaves when gift of clothing is left for it, F451.5.10.9. Ausgelohnt, F480. House-spirits.

KHM 45. "Thumbling's Travels" (Daumerlings Wanderschaft), ATU 700. Thumbling.

- previously classified as a Schwank tale; fairy-tale Schwank (see note for KHM 37).

KHM 46. "Fitcher's Bird" (Fitchers Vogel), ATU 311. Rescue by the Sister.

KHM 47. "The Juniper Tree" (Von dem Machandelboom), ATU 720. The Juniper Tree.

KHM 49. "The Six Swans" (Die sechs Schwäne), ATU 451. The Maiden Who Seeks Her Brothers.

KHM 50. "Brier Rose" (Dornröschen), ATU 410. Sleeping Beauty.

KHM 51. "Foundling" (Fundevogel), ATU 313. The Magic Flight.

KHM 53. "Snow White" (Sneewittchen), ATU 709. Snow White.

KHM 54. "The Knapsack, the Hat, and the Horn" (Der Ranzen, das Hütlein und das Hörnlein), ATU 569. The Knapsack, the Hat and the Horn.

KHM 55. "Rumpelstiltskin" (Rumpelstilzchen), ATU 500. The Name of the Supernatural Helper.

KHM 56. "Sweetheart Roland" (Der Liebste Roland), ATU 1119. The Ogre Kills His Mother (Wife) + ATU 313. Magic Flight + ATU 407. The Girl as Flower.

KHM 57. "The Golden Bird" (Der goldene Vogel), ATU 550. Bird, Horse and Princess.

KHM 60. "The Two Brothers" (Die zwei Brüder), ATU 567. The Magic Bird-Heart + ATU 300. The Dragon-Slayer + ATU 303. The Twins or Blood-Brothers.

KHM 62. "The Queen Bee" (Die Bienenkönigin), ATU 554. The Grateful Animals. KHM 63. "The Three Feathers" (Die drei Federn), ATU 402. The Animal Bride. KHM 64. "The Golden Goose" (Die goldene Gans), ATU 571. "All Stick Together" + ATU 513B. The Land and Water Ship.

KHM 65. "All Fur" (Allerleirauh), ATU 510B. Peau d'Asne.

KHM 66. "The Hare's Bride" (Häsichenbraut), cf. ATU 311. Rescue by the Sister. KHM 67. "The Twelve Huntsmen" (Die zwölf Jäger), ATU 884. The Forsaken

Fiancée: Service as Menial + ATU 313. Magic Flight.

KHM 68. "The Thief and His Master" (De Gaudeif un sien Meester), ATU 325. The Magician and His Pupil. 
KHM 69. "Jorinda and Joringel" (Jorinde und Joringel), ATU 405. Jorinde and Joringel.

KHM 71. "How Six Made Their Way in the World" (Sechse kommen durch die ganze Welt), ATU 513A. Six Go through the Whole World.

KHM 76. "The Pink Flower" (Die Nelke), ATU 652. The Prince Whose Wishes Always Come True.

KHM 79. "The Water Nixie" (Die Wassernixe), ATU 313. The Magic Flight.

KHM 85. “The Golden Children” (Die Goldkinder), ATU 303. The Twins or BloodBrothers.

KHM 88. "The Singing, Springing Lark" (Das singende springende Löweneckerchen), ATU 425A. The Animal as Bridegroom.

KHM 89. "The Goose Girl” (Die Gänsemagd), ATU 533. The Speaking Horsehead. KHM 90. "The Young Giant” (Der junge Riese), ATU 650A. Strong John.

KHM 91. "The Gnome" (Dat Erdmänneken), ATU 301. The Three Stolen Princesses.

KHM 92. "The King of the Golden Mountain" (Der König vom goldenen Berge), ATU 400. The Man on a Quest for His Lost Wife + cf. ATU 810. The Snares of the Evil One + ATU 518. Men Fight over Magic Objects + ATU 974. The Homecoming Husband.

KHM 93. "The Raven" (Die Rabe), ATU 400. The Man on a Quest for His Lost Wife + ATU 518. Men Fight over Magic Objects.

KHM 96. "The Three Little Birds" (De drei Vügelkens), ATU 707. The Three Golden Children.

KHM 97. "The Water of Life" (Das Wasser des Lebens), ATU 551. Water of Life.

KHM 99. "The Spirit in the Glass Bottle" (Der Geist im Glas), ATU 331. The Spirit in the Bottle.

KHM 100. "The Devil's Sooty Brother" (Des Teufels rußiger Bruder), ATU 475. The Man as Heater of Hell's Kettle.

KHM 101. "Bearskin” (Der Bärenhäuter), ATU 361. Bear-Skin.

KHM 103. "The Sweet Porridge” (Der süße Brei), ATU 565. The Magic Mill.

KHM 106. "The Poor Miller's Apprentice and the Cat" (Der arme Müllerbursch und das Kätzchen), ATU 402. The Animal Bride.

KHM 107. "The Two Travelers" (Die beiden Wanderer), ATU 613. The Two Travelers.

KHM 108. "Hans My Hedgehog” (Hans mein Igel), ATU 441. Hans My Hedgehog.

KHM 110. "The Jew in the Thornbush" (Der Jude im Dorn), ATU 592. The Dance among Thorns.

KHM 111. "The Expert Huntsman" (Der gelernte Jäger), ATU 304. The Dangerous Night-Watch. 
KHM 113. “The Two Kings' Children” (De beiden Künigeskinner), ATU 313. Magic Flight.

KHM 114. "The Clever Little Tailor" (Vom klugen Schneiderlein), ATU 850. The Birthmarks of the Princess + ATU 1061. Biting a Stone to Pieces + ATU 1159. The Ogre Caught in the Cleft.

- previously classified as a Schwank tale; fairy-tale parody, which features some elements of the genre (competing for the hand of the princess, magical creature), while subverting others (the trickster protagonist succeeds without magical intervention).

KHM 116. "The Blue Light" (Das blaue Licht), ATU 562. The Spirit in the Blue Light.

KHM 118. "The Three Army Surgeons" (Die drei Feldscherer), ATU 660. The Three Doctors.

- previously classified as a Schwank tale; a Schwank fairy tale which combines fairy-tale (magic salve) and comic elements ("fake" body parts, unexpected consequences of the substitution).

KHM 120. "The Three Journeymen” (Die drei Handwerksburschen), ATU 360.

Bargain of the Three Brothers with the Devil, ATU 1697. "We Three; For Money".

KHM 121. "The Prince Who Feared Nothing" (Der Königssohn, der sich vor nichts fürchtet), ATU 590. The Faithless Mother.

KHM 122. "The Lettuce Donkey” (Der Krautesel), ATU 567. The Magic Bird-Heart + ATU 566. The Three Magic Objects and the Wonderful Fruits.

KHM 123. "The Old Woman in the Forest" (Die Alte im Wald), ATU 442. The Old Woman in the Forest.

KHM 125. "The Devil and His Grandmother" (Der Teufel und seine Großmutter), ATU 812. The Devil's Riddle.

KHM 126. "Faithful Ferdinand and Unfaithful Ferdinand" (Ferenand getrü un Ferenand ungetrü), ATU 531. The Clever Horse.

KHM 127. "The Iron Stove" (Der Eisenofen), ATU 425. The Search for the Lost Husband, 425A. The Animal as Bridegroom.

KHM 129. "The Four Skillful Brothers" (Die vier kunstreichen Brüder), ATU 653. The Four Skillful Brothers.

KHM 130. "One-Eye, Two-Eyes, and Three-Eyes” (Einäuglein, Zweiäuglein und Dreiäuglein), ATU 511. One-Eye, Two-Eyes, Three-Eyes.

KHM 133. "The Worn-out Dancing Shoes" (Die zertanzten Schuhe), ATU 306. The Danced-out Shoes.

KHM 134. "The Six Servants" (Die sechs Diener), ATU 513A. Six Go through the Whole World + ATU 900. King Thrushbeard. 
KHM 135. "The White Bride and the Black Bride" (Die weiße und die schwarze Braut), ATU 403. The Black and the White Bride.

KHM 136. "Iron Hans" (Der Eisenhans), ATU 314. Goldener (cf. ATU 502. The Wild Man).

KHM 137. "The Three Black Princesses" (De drei schwatten Prinzessinnen), cf. ATU 400. The Man on a Quest for His Lost Wife.

KHM 141. "The Little Lamb and the Little Fish" (Das Lämmchen und Fischchen), ATU 450. Little Brother and Little Sister.

KHM 142. "Simelei Mountain" (Simeliberg), ATU 954. The Forty Thieves.

KHM 144. "The Donkey” (Das Eselein), ATU 430. The Donkey.

KHM 160. "A Tale with a Riddle" (Rätselmärchen), cf. ATU 407. The Girl as Flower.

KHM 161. "Snow White and Rose Red" (Schneeweißchen und Rosenrot), ATU 426. The Two Girls, the Bear, and the Dwarf.

KHM 163. "The Glass Coffin” (Der gläserne Sarg), cf. ATU 410. Sleeping Beauty + ATU 552. The Girls Who Married Animals.

KHM 165. "The Griffin" (Der Vogel Greif), ATU 610. The Healing Fruits (+ ATU 570. The Rabbit-Herd) + ATU 513B. The Land and Water Ship + ATU 461. Three Hairs from the Devil's Beard.

KHM 166. "Strong Hans" (Der starke Hans), ATU 650A. Strong John + ATU 301. The Three Stolen Princesses.

KHM 169. "The House in the Forest" (Das Waldhaus), ATU 431. The House in the Forest.

KHM 179. "The Goose Girl at the Spring” (Die Gänsehirtin am Brunnen), ATU 923. Love Like Salt.

KHM 181. "The Nixie in the Pond" (Die Nixe im Teich), ATU 316. The Nix of the Mill-Pond + ATU 313. The Magic Flight.

KHM 182. "The Gifts of the Little Folk" (Die Geschenke des kleinen Volkes), ATU 503. The Gifts of the Little People.

KHM 183. "The Giant and the Tailor" (Der Riese und der Schneider), ATU 1049.

The Heavy Axe + ATU 1053. Shooting Wild Boars + ATU 1051. Bending a Tree.

- previously classified as a Schwank tale; a Schwank fairy tale, which features some elements of the genre (magical antagonist, impossible tasks), while subverting others (trickster hero succeeds without magical assistance, lack of a traditional fairy-tale ending).

KHM 186. "The True Bride" (Die wahre Braut), cf. ATU 313. The Magic Flight. KHM 188. "Spindle, Shuttle, and Needle" (Spindel, Weberschiffchen und Nadel), ATU 585. Spindle, Shuttle, and Needle. 
KHM 191. "The Little Hamster From the Water" (Das Meerhäschen), ATU 329. Hiding from the Princess.

KHM 193. "The Drummer" (Der Trommler), ATU 400. The Man on a Quest for His Lost Wife + ATU 518. Men Fight over Magic Objects + ATU 313. The Magic Flight.

KHM 196. "Old Rinkrank" (Oll Rinkrank), cf. ATU 530. The Princess on the Glass Mountain + cf. ATU 1159. The Ogre Caught in the Cleft.

KHM 197. "The Crystal Ball” (Die Kristallkugel), ATU 552. The Girls Who Married Animals + ATU 518. Men Fight over Magic Objects + ATU 302. The Ogre's (Devil's) Heart in the Egg.

KHM 199. "The Boots of Buffalo Leather" (Der Stiefel von Büffelleder), ATU 952. The King and the Soldier.

KHM 201 (KL 1). "Saint Joseph in the Forest" (Der heilige Joseph im Walde), ATU 480. The Kind and the Unkind Girls.

\section{Secondary research corpus: other genres in the KHM}

\section{i. Animal tales}

KHM 2. "The Companionship of the Cat and the Mouse" (Katze und Maus in Gesellschaft), ATU 15. The Theft of Food by Playing Godfather.

KHM 5. "The Wolf and the Seven Young Kids" (Der Wolf und die sieben jungen Geißlein), ATU 123. The Wolf and the Kids.

- previously classified as a didactic tale; cautionary animal tale.

KHM 8. "The Marvelous Minstrel" (Der wunderliche Spielmann), ATU 38. Claw in Split Tree, ATU 151. A Man Teaches a Wild Animal to Play the Fiddle.

KHM 10. "Riffraff” (Das Lumpengesindel), ATU 210. Rooster, Hen, Duck, Pin, and Needle on a Journey.

KHM 18. "The Straw, the Coal, and the Bean" (Strohhalm, Kohle und Bohne), ATU 295. The Bean (Mouse), the Straw, and the Coal + Mot. A2793.1. Why bean has black stripe.

- previously classified as an aetiological tale; humorous (Schwank) animal tale with an aetiological coda.

KHM 23. "The Mouse, the Bird, and the Sausage" (Von dem Mäuschen, Vögelchen und der Bratwurst), ATU 85. The Mouse, the Bird, and the Sausage.

KHM 27. "The Bremen Town Musicians" (Die Bremer Stadtmusikanten), ATU 130.

The Animals in Night Quarters.

KHM 38. "The Wedding of Mrs. Fox" (Die Hochzeit der Frau Füchsin), ATU 65.

The She-Fox's Suitors. 
KHM 41. "Herr Korbes" (Herr Korbes), ATU 210. Rooster, Hen, Duck, Pin, and Needle on a Journey.

KHM 48. "Old Sultan" (Der alte Sultan), ATU 101. The Old Dog as Rescuer of the Child (Sheep) + ATU 103. War between Wild Animals and Domestic Animals. KHM 58. "The Dog and the Sparrow" (Der Hund und der Sperling), ATU 248. The Dog and the Sparrow, ATU 223. The Bird and the Jackal.

KHM 72. "The Wolf and the Man" (Der Wolf und der Mensch), ATU 157. Animals Learn to Fear Men.

KHM 73. "The Wolf and the Fox" (Der Wolf und der Fuchs), ATU 41. The Wolf Overeats in the Cellar + ATU 122. Animal Loses His Prey Because His Victim Can Escape by False Plea.

KHM 74. "The Fox and His Cousin" (Der Fuchs und die Frau Gevatterin), ATU 3*. The Wolf Supplies Food for the Fox + cf. ATU 37. The Fox as Nursemaid for the Mother Bear + ATU 4. Sick Animal Carries the Healthy One.

KHM 75. "The Fox and the Cat" (Der Fuchs und die Katze), ATU 105. The Cat's Only Trick.

KHM 102. "The Wren and the Bear" (Der Zaunkönig und der Bär), ATU 222. War between Birds (Insects) and Quadrupeds.

KHM 132. "The Fox and the Horse" (Der Fuchs und das Pferd), ATU 47A. The Fox Hangs Onto the Horse's Tail.

KHM 171. "The Wren” (Der Zaunkönig), ATU 221A. Test: Who Can Fly Highest?, ATU 221B. Test: Who Can Go Deepest in Earth? + cf. Mot. A2571. How animals received their names, Mot. A2494.13. Enmities of birds, Mot. A2494.13.4. Enmity between owl and mouse, Mot. A2332.6.6. Why owl is blind by day, Mot. A2491.2. Why owl avoids daylight.

- previously classified as an aetiological tale; aetiological animal tale.

KHM 172. "The Flounder" (Die Scholle), ATU 250A. The Flounder's Crooked Mouth.

- previously classified as an aetiological tale; aetiological animal tale.

KHM 173. "The Bittern and the Hoopoe" (Rohrdommel und Wiedehopf), ATU 236*. Miscellaneous Tales with Imitation of Bird Sounds.

- previously classified as an aetiological tale; aetiological animal tale.

KHM 187. "The Hare and the Hedgehog" (Der Hase und der Igel), ATU 275C. The Race between Hare and Hedgehog.

KHM 190. "The Crumbs on the Table" (Die Brosamen auf dem Tisch), ATU 106. Animals' Conversation. 


\section{ii. Folk tales (realistic tales/novelle)}

KHM 7. "The Good Bargain" (Der gute Handel), ATU 1642. The Good Bargain + ATU 1610. Sharing the Reward + ATU 1642A. The Borrowed Coat.

- previously classified as a Schwank tale; humorous (Schwank) folk tale. KHM 22. "The Riddle" (Das Rätsel), ATU 851. The Princess Who Cannot Solve the Riddle.

KHM 32. "Clever Hans" (Der gescheite Hans), ATU 1685. The Foolish Bridegroom + ATU 1696. "What Should I Have Said (Done)?" + Mot. J2129.4. Fool sticks needle in haywagon.

- previously classified as a Schwank tale; humorous (Schwank) folk tale.

KHM 34. "Clever Else" (Die kluge Else), ATU 1450. Clever Elsie (cf. ATU 1387.

The Woman Goes to Get Beer, ATU 1430A. Foolish Plans for the Unborn Child) + ATU 1383. The Woman Does Not Know Herself.

- previously classified as a Schwank tale; humorous (Schwank) folk tale.

KHM 40. "The Robber Bridegroom" (Der Räuberbräutigam), ATU 955. Robber Bridegroom.

KHM 52. "King Thrushbeard" (König Drosselbart), ATU 900. King Thrushbeard. KHM 59. "Freddy and Katy" (Der Frieder und das Katherlieschen), ATU 1387. The Woman Goes to Get Beer + ATU 1541. For the Long Winter (= ATU 1385*. Learning about Money) + ATU 1291. One Cheese Sent to Bring Back Another + ATU 1653. The Robbers under the Tree + cf. ATU 1383. The Woman Does Not Know Herself + ATU 1791. The Sexton Carries the Clergyman.

- previously classified as a Schwank tale; humorous (Schwank) folk tale. KHM 61. "Little Farmer" (Das Bürle), ATU 1535. The Rich and the Poor Farmer + ATU 1358C. Trickster Discovers Adultery: Food Goes to Husband Instead of Lover + 1358A. Hidden Lover Buys Freedom from Discoverer + ATU 1297*. Jumping into the River after Their Comrade.

- previously classified as a Schwank tale; humorous (Schwank) folk tale. KHM 70. "The Three Sons of Fortune" (Die drei Glückskinder), ATU 1650. The Three Lucky Brothers + ATU 1202. The Dangerous Sickle + ATU 1281. Getting Rid of the Unknown Animal, ATU 1651. Whittington's Cat + cf. ATU 1282. House Burned Down to Rid It of Insects.

- previously classified as a Schwank tale; humorous (Schwank) folk tale.

KHM 77. "Clever Gretel" (Das kluge Gretel), ATU 1741. The Priest's Guest and the Eaten Chickens.

- previously classified as a Schwank tale; humorous (Schwank) folk tale. KHM 78. "The Old Man and His Grandson" (Der alte Großvater und der Enkel), ATU 980(1). The Ungrateful Son.

- previously classified as a didactic tale; a realistic exemplum.

KHM 83. "Lucky Hans" (Hans im Glück), ATU 1415. Lucky Hans. 
- previously classified as a Schwank tale; humorous (Schwank) folk tale.

KHM 84. "Hans Gets Married" (Hans heiratet), ATU 859(3) + ATU 859(2). The Penniless Bridegroom Pretends to Wealth.

KHM 94. "The Clever Farmer's Daughter" (Die kluge Bauerntochter), ATU 875. The Clever Farmgirl.

KHM 95. "Old Hildebrand" (Der alte Hildebrand), ATU 1360C. Old Hildebrand.

- previously classified as a Schwank tale; humorous (Schwank) folk tale.

KHM 98. "Doctor Know-It-All” (Doktor Allwissend), ATU 1641. Doctor Know-All.

- previously classified as a Schwank tale; humorous (Schwank) folk tale.

KHM 104. "The Clever People" (Die klugen Leute), ATU 1385. The Foolish Wife's

Security + ATU 1384. The Husband Hunts Three Persons as Stupid as His Wife + ATU 1540. The Student from Paradise (Paris).

- previously classified as a Schwank tale; humorous (Schwank) folk tale. KHM 105 (iii). "Tales About Toads" (Märchen von der Unke), Mot. B216.

Knowledge of animal languages + Mot. B212. Animal understands human speech + Mot. B211.7.1. Speaking frog.

- previously classified as a Schwank tale; a nonsense tale.

KHM 115. "The Bright Sun Will Bring It to Light" (Die klare Sonne bringt's an den Tag), ATU 960. The Sun Brings All to Light.

KHM 119. "The Seven Swabians" (Die sieben Schwaben), ATU 1321C. Fools are

Frightened at the Humming of Bees + ATU 1231. The Attack on the Hare (Crayfish, Toad, Frog) + ATU 1297*. Jumping into the River after Their Comrade.

- previously classified as a Schwank tale; humorous (Schwank) folk tale. KHM 124. "The Three Brothers" (Die drei Brüder), ATU 654. The Three Agile Brothers.

- previously classified as a Schwank tale; humorous (Schwank) folk tale with some elements of the fairy tale (the rags-to-riches trajectory) and the tall tale (exaggeration).

KHM 128. "The Lazy Spinner" (Die faule Spinnerin), ATU 1405. The Lazy Spinning Woman.

- previously classified as a Schwank tale; humorous (Schwank) folk tale.

KHM 138. "Knoist and His Three Sons" (Knoist un sine dre Sühne), ATU 1965. The Disabled Comrades.

- previously classified as a Schwank tale; humorous (Schwank) folk tale, specifically, a tall tale.

KHM 139. "The Maiden From Brakel" (Dat Mäken von Brakel), ATU 1476A. Prayer to Christ Child's Mother.

- previously classified as a Schwank tale; humorous (Schwank) folk tale. 
KHM 143. "Going Traveling” (Up Reisen gohn), ATU 1696. "What Should I Have Said (Done)?"

- previously classified as a Schwank tale; humorous (Schwank) folk tale. KHM 146. "The Turnip" (Die Rübe), ATU 1689A. Two Presents for the King + ATU 1535. The Rich and the Poor Farmer.

- previously classified as a Schwank tale; humorous (Schwank) folk tale.

KHM 149. "The Beam" (Der Hahnenbalken), ATU 987. False Magician Exposed by Clever Girl + ATU 1290. Swimming in the Flax-Field.

- previously classified as a Schwank tale; humorous (Schwank) folk tale.

KHM 150. "The Old Beggar Woman" (Die alte Bettelfrau), Mot. N300. Unlucky accidents + Mot. S20. Cruel children and grandchildren.

KHM 151. "The Three Lazy Sons" (Die drei Faulen), ATU 1950. The Three Lazy Ones.

- previously classified as a Schwank tale; humorous (Schwank) folk tale, specifically, a tall tale.

KHM 151a. "The Twelve Lazy Servants" (Die zwölf faulen Knechte), ATU 1950.

The Three Lazy Ones.

- previously classified as a Schwank tale; humorous (Schwank) folk tale, specifically, a tall tale.

KHM 152. "The Little Shepherd Boy" (Das Hirtenbüblein), ATU 922. The Shepherd Substituting for the Clergyman Answers the King's Questions.

KHM 155. "Choosing a Bride" (Die Brautschau), ATU 1452. Thrifty Cutting of Cheese.

- previously classified as a Schwank tale; humorous (Schwank) folk tale.

KHM 156. "The Leftovers" (Die Schlickerlinge), ATU 1451. The Thrifty Girl.

- previously classified as a Schwank tale; humorous (Schwank) folk tale.

KHM 158. "The Tale About the Land of Cockaigne" (Das Märchen vom

Schlauraffenland), ATU 1935. Topsy Turvy Land + ATU 1930. Schlaraffenland.

- previously classified as a Schwank tale; humorous (Schwank) folk tale, specifically, a tall tale.

KHM 159. "A Tall Tale From Ditmarsh" (Das dithmarsische Lügenmärchen), ATU 1935. Topsy Turvy Land + ATU 1930. Schlaraffenland.

- previously classified as a Schwank tale; humorous (Schwank) folk tale, specifically, a tall tale.

KHM 162. "The Clever Servant" (Der kluge Knecht), ATU 1348*. The Boy with Active Imagination.

- previously classified as a Schwank tale; humorous (Schwank) folk tale.

KHM 164. "Lazy Heinz" (Der faule Heinz), ATU 1430. The Man and His Wife Build Air Castles, 1430A. Foolish Plans for the Unborn Child + cf. ATU 288B*. The Over-Hasty Toad (Beetle). 
- previously classified as a Schwank tale; humorous (Schwank) folk tale. KHM 168. "Lean Lisa" (Die hagere Liese), ATU 1430. The Man and His Wife Build Air Castles, 1430A. Foolish Plans for the Unborn Child.

- previously classified as a Schwank tale; humorous (Schwank) folk tale.

KHM 170. "Sharing Joys and Sorrows" (Lieb und Leid teilen), cf. Mot. T256. The quarrelsome wife or husband, J1280. Repartee with ruler (judge, etc.), J1290. Reduction ad absurdum of question or proposal.

KHM 174. "The Owl" (Die Eule), Mot. A2494.13. Enmities of birds + Mot. A2332.6.6. Why owl is blind by day + ATU 1282. House Burned Down to Rid It of Insects.

- previously classified as a Schwank tale; humorous (Schwank) folk tale. KHM 185. "The Poor Boy in the Grave" (Der arme Junge im Grab), ATU 1408C. The String of Chickens + ATU 1296B. Doves in the Letter + ATU 1313. The Man Who Wanted to Commit Suicide.

- previously classified as a Schwank tale; humorous (Schwank) folk tale. KHM 192. “The Master Thief” (Der Meisterdieb), ATU 1525A. Tasks for a Thief + ATU 1740. Candles on the Crayfish + ATU 1737. The Clergyman in the Sack to Heaven.

- previously classified as a Schwank tale; humorous (Schwank) folk tale. KHM 198. "Maid Maleen” (Jungfrau Maleen), ATU 870. The Princess Confined in the Mound.

\section{iii. Formula tales}

KHM 30. "The Louse and the Flea" (Läuschen und Flöhchen), ATU 2022. The Death of the Little Hen.

- animal formula (cumulative) tale.

KHM 80. "The Death of the Hen" (Von dem Tode des Hühnchens), ATU 2021. The Rooster and the Hen.

- animal formula (cumulative) tale.

KHM 86. "The Fox and the Geese" (Der Fuchs und die Gänse), ATU 227. Geese Ask for Respite for Prayer.

- animal formula (endless) tale.

KHM 131. "Pretty Katrinelya and Pif Paf Poltree" (Die schöne Katrinelje und Pif Paf Poltrie), ATU 2019. Pif Paf Poltrie.

KHM 140. "The Domestic Servants" (Das Hausgesinde), ATU 1940. The Extraordinary Names.

KHM 184. "The Nail” (Der Nagel), ATU 2039. The Horseshoe Nail.

KHM 200. "The Golden Key” (Der goldene Schlüssel), ATU 2260. The Golden Key. 


\section{iv. Legends}

KHM 28. "The Singing Bone" (Der singende Knochen), ATU 780. The Singing Bone.

- fairy-tale religious legend.

KHM 39 (ii). "The Elves" (Die Wichtelmänner), ATU 476** Midwife in the Underworld + Mot. D2011. Years thought days.

KHM 39 (iii). "The Elves" (Die Wichtelmänner), Mot. F321.1. Changeling + Mot. D512.1. Transformation when one expresses astonishment at smith drawing water in an egg-shell + Mot. F321.1.1.1. Changeling betrays his age when his wonder is excited + Mot. F321.1.1.5. Changeling calculates his age by the age of the forest + Mot. F451.5.17.1. Invisible dwarfs at christening feast made to speak by brewing beer in egg-shell + Mot. F481.4. Brewing in eggshell to drive away cobold.

KHM 42. "The Godfather" (Der Herr Gevatter), ATU 332. Godfather Death + ATU 334. Household of the Witch.

KHM 43. "Mother Trudy" (Frau Trude), ATU 334. Household of the Witch.

- previously classified as a didactic tale; cautionary legend, which uses the tragic fate of the protagonist to communicate lessons about the importance of obedience.

KHM 44. "Godfather Death" (Der Gevatter Tod), ATU 332. Godfather Death.

KHM 81. "Brother Lustig" (Bruder Lustig), ATU 785. Lamb's Heart + ATU 330.

The Smith and the Devil.

- previously classified as a Schwank tale; religious Schwank legend which provides humorous depictions of religious figures (St Peter, devils), occurrences (miracles), and places (hell).

KHM 82. "Gambling Hans" (De Spielhansl), ATU 330. The Smith and the Devil.

- previously classified as a Schwank tale; a religious Schwank legend, which features a central trickster character (he manages to outsmart death) and subverts traditional images of the afterlife.

KHM 105 (i). "Tales About Toads" (Märchen von der Unke), ATU 285. The Child and the Snake, ATU 285A. The Man and the Wounded Snake (= Mot. B391.1. Child feeds snake from its milk-bottle + Mot. B765.6. Snake eats milk and bread with child).

KHM 105 (ii). "Tales About Toads" (Märchen von der Unke), ATU 672. The Serpent's Crown.

KHM 117. "The Stubborn Child" (Das eigensinnige Kind), ATU 760**. The Obstinate Child.

- previously classified as a didactic tale; a cautionary religious legend.

KHM 145. "The Ungrateful Son" (Der undankbare Sohn), ATU 980D. Meat Springs as a Toad on the Face of an Ungrateful Son. 
- previously classified as a didactic tale; legendary exemplum.

KHM 147. "The Rejuvenated Little Old Man" (Das junggeglühte Männlein), ATU 753. Christ and the Smith.

- previously classified as an aetiological tale; religious legend with an aetiological coda and Schwank elements.

KHM 148. "The Animals of the Lord and the Devil" (Des Herrn und des Teufels

Getier), ATU 773. Contest of Creation between God and the Devil + ATU 1184.

The Last Leaf.

- previously classified as an aetiological tale; religious aetiological tale with Schwank elements (outwitting the devil).

KHM 154. "The Stolen Pennies" (Der gestohlene Heller), Mot. E423.1.1. Revenant as dog + Mot. E411. Dead cannot rest because of sin + Mot. E451. Ghost finds rest when certain thing happens + Mot. E451.5.1. Money must be distributed to beggars so that ghost may be laid.

KHM 175. "The Moon" (Der Mond), Mot. A758. Theft of the moon + Mot. A755.4.2. Moon stolen and divided into quarters + Mot. A755.2. Moon's phases caused by watcher's death.

- previously classified as an aetiological tale; aetiological legend with Schwank elements.

KHM 176. "The Life Span" (Die Lebenszeit), ATU 173. Human and Animal Life Spans are Readjusted.

- previously classified as an aetiological tale; religious aetiological legend.

KHM 177. "The Messengers of Death" (Die Boten des Todes), ATU 335. Death's Messengers.

KHM 180. "Eve's Unequal Children" (Die ungleichen Kinder Evas), ATU 758. The Various Children of Eve.

- previously classified as an aetiological tale; religious aetiological legend.

KHM 189. "The Peasant and the Devil" (Der Bauer und der Teufel), ATU 1030. The Crop Division.

- previously classified as a Schwank tale; Schwank legend which portrays the devil as someone who lacks intelligence and is therefore easily outwitted. KHM 194. "The Ear of Corn" (Die Kornähre), ATU 779G*. Crime against Grain.

- previously classified as an aetiological tale; religious aetiological legend.

KHM 202 (KL 2). "The Twelve Apostles” (Die zwölf Apostel), ATU 766. The Seven Sleepers + Mot. V232. Angel as helper + Mot. V292. The Apostles of Christ.

- previously classified as an aetiological tale; religious aetiological legend. 
KHM 207 (KL 7). “The Blessed Virgin's Little Glass” (Muttergottesgläschen), Mot. A2655. Origin of bindweed (convolvulus sepium) + Mot. A2711.4.3. Plant receives name because of service to Virgin Mary.

- previously classified as an aetiological tale; religious aetiological legend.

KHM 210 (KL 10). "The Hazel Branch" (Die Haselrute), Mot. A2711.4.1. Hazel gives Virgin Mary shelter + Mot. D1402.10.2. Rod from magic hazel-tree kills snake immediately.

- previously classified as an aetiological tale; religious aetiological legend.

\section{v. Religious tales}

KHM 35. "The Tailor in Heaven" (Der Schneider im Himmel), ATU 800. The Tailor in Heaven.

- previously classified as a Schwank tale; a religious Schwank, which inverts traditional views of heaven (the afterlife) and how it can be obtained.

KHM 87. "The Poor Man and the Rich Man" (Der Arme und der Reiche), ATU 750A. The Three Wishes.

KHM 109. "The Little Shroud” (Das Totenhemdchen), ATU 769. The Child's Grave. KHM 112. "The Fleshing Flail from Heaven" (Der Dreschflegel vom Himmel), ATU 1960A. The Great Ox + 1960G. The Great Tree + ATU 1174. Making a Rope of Sand, ATU 1889. Münchhausen Tales + ATU 1882. The Man Who Fell Out of a Balloon.

- previously classified as a Schwank tale; a religious Schwank, which plays with traditional views of heaven (angels are engaged in manual labour) and how it can be obtained (climbing a tall plant).

KHM 153. "The Star Coins" (Die Sterntaler), ATU 779H*. Star Money.

- previously classified as a didactic tale; religious exemplary tale.

KHM 157. "The Sparrow and His Four Children" (Der Sperling und seine vier Kinder), cf. ATU 157B. The Sparrow and His Sons.

KHM 167. "The Peasant in Heaven" (Das Bürle im Himmel), ATU 802. The Farmer in Heaven.

KHM 178. "Master Pfriem" (Meister Pfriem), ATU 801. Meister Pfriem (cf. ATU 1248. Tree-Trunks Laid Crosswise on a Sledge + ATU 1180. Catching Water in a Sieve).

- previously classified as a Schwank tale; a religious Schwank which provides a humorous portrayal of heaven as a place of manual labour, rather than blissful, care-free existence. 
KHM 195. "The Grave Mound" (Der Grabhügel), ATU 815. The Devil who Skins a Corpse + ATU 1130. Counting Out Pay.

KHM 203 (KL 3). "The Rose" (Die Rose), Mot. Z142.1. White rose the symbol of death.

KHM 204 (KL 4). "Poverty and Humility Lead to Heaven" (Armut und Demut führen zum Himmel), Mot. K1815.1.1. Pious pilgrim dies unknown in his father's house + Q523.4. Penance: living under stairs as mendicant + Mot. A2611.0.1. Plants from grave of dead person or animal.

KHM 205 (KL 5). “God's Food” (Gottes Speise), ATU 751G*. Bread Turned to Stone.

KHM 206 (KL 6). "The Three Green Twigs" (Die drei grünen Zweige), ATU 756A. The Self-Righteous Hermit.

KHM 208 (KL 8). "The Little Old Lady" (Das alte Mütterchen), ATU 934C. Death Forestalls Evil Fates.

KHM 209 (KL 9). "The Heavenly Wedding” (Die himmlische Hochzeit), ATU 767. Food for the Crucifix. 


\section{Tiivistelmä}

Väitöskirja tarkastelee narratiivista tilaa ja tilallista siirtymää Jacob ja Wilhelm Grimmin julkaisemassa satukokoelmassa Kinder- und Hausmärchen (Lasten ja kotitalouksien tarinat, 1857). Tutkimuskohteen korpus, joka koostuu 215 erilaisesta tekstistä, on jaettu kahteen osaan: primaarikorpukseen, johon perinteiset sadut kuuluvat, ja sekundaarikorpukseen, johon kuuluvat eläinsadut, opettavaiset sadut, etiologiset sadut, kansantarinat, formulatarinat, legendat, uskonnolliset tarinat ja humoristiset (Schwank) tarinat. Sekundaarikorpuksen avulla voi analysoida perinteisiä satuja vertailemalla niitä muihin lyhytproosan narratiivisiin lajityyppeihin.

Narratiivista tilaa ei ole tähän mennessä riittävästi tarkasteltu tieteellisessä kirjallisuudessa, jossa se tavallisesti käsitetään pelkkänä passiivisena taustana tapahtumille, joiden täytyy sijoittua jonnekin. Tällainen näkemys on jossain määrin ymmärrettävä ottaen huomioon pitkään jatkunut kiinnostuksen puute tilallisiin kysymyksiin humanistissa tieteissä ja sosiaalitieteissä (ennen ns. spatiaalista käännettä) sekä perinteisten satujen tilallinen epämääräisyys. Säästeliäänä lajityyppinä perinteinen satu nimittäin jättää kertomatta kaiken, mikä ei suoraan vaikuta juoneen, kuten henkilöiden ja ympäristön tarkemman kuvailun. Aikaisempi tutkimus keskittyy enimmäkseen perinteisen sadun abstraktiin ja epämääräiseen tilaan tai sen symboliseen ja metaforiseen merkitykseen. Huomion keskipisteessä ei siis ole tila sinänsä, vaan se mitä tila kertoo itse tarinan tai sen henkilöiden merkityksestä.

Aikaisemmasta tutkimuksesta poiketen tämä väitöskirja tarkastelee narratiivista tilaa aineellisena kolmiulotteisena ympäristönä sekä autonomisena ja välttämättömänä kerronnan keinona, jolla on merkitystä sinänsä. Tutkimus keskittyy perinteisen sadun rakenteeseen, sen esittämiseen (ts. niihin narratiivisiin ja lingvistisiin strategioihin, joiden avulla tilaan liittyvää informaatiota välitetään) sekä eräisiin yleispiirteisiin. Väitöskirjassa tarkastellaan myös tilallista siirtymää tärkeänä edellytyksenä ihmisprotagonistin ja maagisen aineksen vuorovaikutukselle, joka puolestaan on perinteisen sadun lajityypin tärkein tekijä. Lisäksi tilallinen siirtymä toimii keinona kytkeä yksittäiset paikat laajempaan tilalliseen verkostoon.

Tutkimus sijoittuu satujen tutkimuksen teoreettiseen viitekehykseen sekä narratologian metodologiseen ja analyyttiseen kehikkoon. Se ei sitoudu yhtenkään 
erityiseen satujen tutkimuksen teoriaan, vaan systematisoi ja kehittää edelleen eri lähestymistapojen tuottamaa tietoa. Erityisen tärkeitä tälle tutkimukselle ovat satujen tutkimuksen puolella Max Lüthin ja Alfred Messerlin sekä narratologian puolella Marie-Laure Ryanin ja Katrin Dennerleinin työt.

Satujen rakenteen analyysissa sovelletaan Marie-Laure Ryanin kehittämää mallia, joka koostuu viidestä tilallisesta yksiköstä: tilallisesta kehyksestä, tarinan asetelmasta, tarinan tilasta, tarinan maailmasta ja narratiivisesta universumista. Sovellettaessa satuun tätä mallia paljastuvat sadun narratiivisen tilan monikerroksisuus sekä monimutkaiset prosessit, joilla tilaa rakennetaan lukijan ja tekstin jatkuvassa vuorovaikutuksessa. Soveltaakseen yleistä mallia perinteisen sadun analysointiin tutkimus laajentaa mallia lisäämällä käyttöön uuden kategorian alueen - johon kuuluvat ne tilat, joissa vallitsevat samanlaiset luonnonlait. Perinteinen satu sisältää kaksi aluetta: ei-maagisen ja maagisen. Kahden kvalitatiivisesti vastakkaisen alueen olemassaolo ei ole luonteenomaista ainoastaan perinteisille saduille, vaan sama ilmiö tavataan myös eräissä narratiivisen lyhytproosan lajityypeissä kuten legendoissa ja uskonnollisissa kertomuksissa. Väitöskirja esittääkin sadun ominaispiirteiden syntyvän kahden alueen vuorovaikutuksesta ja niiden välisen rajan ylittämisen tavoista. Tarkemmin sanoen alueiden välinen raja on mahdollista ylittää sen kummaltakin puolelta, mutta vain tilapäisesti (liikkuvan henkilön on tarinan lopussa palattava omalle alueelleen) ja tiettyjen edellytysten vallitessa. Vaikka kyseiset edellytykset ovat erilaiset ei-maagisille ja maagisille henkilöille, ne tyypillisesti riippuvat kontaktin luomisesta kohdealueeseen, yleensä portinvartijan kautta. Maagiselle alueelle päästäkseen ei-maagisten henkilöiden on osoitettava myönteisiä ominaisuuksia kuten sääliä, rohkeutta ja anteliaisuutta tai seurattava tarinaan kuuluvia automaattisia ohjeita. Maagiselle alueelle joutuvat eksyneet tai hyljätyt henkilöt, mutta se voi myös houkutella ihmisiä puoleensa poikkeuksellisilla esineillä, eläimillä sekä visuaalisilla tai auditiivisilla signaaleilla joko auttaakseen tai vahingoittaakseen heitä tai pyytääkseen heidän apuaan. Pahantahtoinen maaginen voi pyytämättä tunkeutua ei-maagiselle alueelle tai manipuloida ei-maagista henkilöä kutsumalla häntä luokseen. Hyväntahtoinen maaginen sen sijaan saapuu ei-maagiselle alueelle (usein tahattomasti) ei-maagisen henkilön kutsusta, joka voi olla verbaalinen (eksplisiittinen kutsu, häälupaus, toive, maaginen tai muu verbaalinen formula, avunhuuto) tai ei-verbaalinen (itku, pahat ajatukset, lannistuminen tai epätoivoa ilmaiseva ele tai käytös).

Toissijaisen korpuksen analysointi tilallisesta näkökulmasta johti tutkimuksessa sen alkuperäisen luokittelun tarkennukseen. Tietyntyyppisillä narratiiveilla (didaktiset, etiologiset, Schwank) ei näet ole pysyvää tilallista rakennetta, vaan niihin kuuluvien alueiden lukumäärä ja luonne voivat vaihdella. Niinpä päädytään siihen, etteivät nämä lajityypit ole riippumattomia, vaan niiden edustajat ovat alalajeja sellaisista lajityypeistä, joilla on vakiintunut määrä alueita. Tulokset sitä paitsi 
johtavat perinteisen sadun alkuperäisen työmääritelmän uudelleenarviointiin, jota (tilallisuus huomioon ottaen) voidaan luonnehtia sellaiseksi lajityypiksi, joka kuvaa kahta selvästi toisistaan erottuvaa ja laadultaan erilaista aluetta: ei-maagista ja maagista. Tarinan edetessä näiden alueiden on (tilapäisesti) jouduttava kosketuksiin, minkä aikaansaa tilallinen siirtymä - nimittäin alueiden välisen rajan ylitys. Rajan voi ylittää sen kummaltakin puolelta, mutta vain tilapäisesti ja mikäli tietyt ehdot täyttyvät. Tällä tapaa tutkimus korostaa narratiivisen tilan mahdollisuuksia lajityyppiluokittelun yhtenä mahdollisena kategoriana.

Tutkimus osoittaa myös, ettei eksplisiittisen tilallisen tiedon puuttumista perinteisestä sadusta pidä tulkita sen merkityksettömyydeksi, vaan osoitukseksi kyseisen lajityypin säästeliäästä luonteesta. Toisin sanoen se tosiseikka, että perinteinen satu harvemmin kertoo tilasta avoimesti ja yksityiskohtaisesti, ei tarkoita tilan merkityksettömyyttä, vaan on osoitus siitä, että kyseisellä lajityypillä on muita keinoja välittää tilallista informaatiota joko paikkoja suoraan kuvaamalla ja nimeämällä tai kerronnan epäsuorilla viittauksilla henkilöihin, esineisiin, paikkoihin ja materiaaleihin. Kaiken kaikkiaan tämä tutkimus tunnistaa perinteisen sadun narratiivisen tilan kerronnan dynaamisena osana, joka rakentuu henkilöiden, esineiden, tapahtumien ja muiden tilojen vuorovaikutuksesta. Siinä mielessä tila ei ole (kuten sen aikaisempien määritelmien perusteella voisi luulla) pelkkä tapahtumien näyttämö ja tausta, vaan monimutkaisen suhdeverkoston osatekijä ja myös lajityyppiluokittelun tärkeä tekijä.

AVAINSANAT: satu, narrativiinen tila, tilalllinen siirtymä, Kinder- und Hausmärchen, Jacob ja Wilhelm Grimm, narratologia, laji 


\section{Author's biography}

Nada Kujundžić holds a Master's degree in English and Comparative Literature from the Faculty of Humanities and Social Sciences in Zagreb. From 2016 to 2019, she taught courses in English and children's literature at the Faculty of Teacher Education. She has been publishing scholarly papers, book reviews, reports, and essays in Croatian and international journals since 2010. She has presented her research at numerous conferences, workshops, research seminars, and summer schools in Croatia and abroad. She acted as member of the organising board for two conferences: Stoljeće „Priča iz davnine“ Ivane Brlić-Mažuranić (Zagreb, 12-15 October 2016) and Coming of Age: Young Scholars in the Field of Folkloristics, Ethnology, and Anthropology (Göttingen, 26 March 2017). She has given a number of invited lectures in Croatia and abroad, and organised several workshops dedicated to fairy tales and writing book reviews. She acted as expert adviser during the development of Ivana's House of Fairy Tales - visitors' centre (Ogulin, Croatia) and was a member of the installation research project Building Intercultural Bridges Through Children's Literature Translations: Texts, Contexts and Strategies (BIBRICH; 2015-2018). She has undertaken research trips to Finland (doctoral exchange programme, University of Turku, 2011-2012) and Canada (Wirth Croatian Doctoral Research Fellow, University of Alberta, 2015-2016). She is a member of the European Narratology Network, the Croatian Association of Researchers in Children's Literature, and the International Society for Ethnology and Folklore (SIEF). She is the Chair of SIEF's Young Scholars Working Group. Her research interests include fairy tales and their adaptations, children's literature, oral literature, popular culture, film, and translation.

\section{Publications}

Mišík, Matúš and Nada Kujundžić (eds.). (forthcoming). Energy Humanities. Current State and Future Directions. Cham: Springer.

Kujundžić, Nada i Ivana Milković. 2019. “Pooh, čitaj Pu': Imena u hrvatskim prijevodima zbirke priča Winnie-the-Pooh A. A. Milnea". In Simljana Narančić Kovač and Ivana Milković (eds.), Prijevodi dječje književnosti: pogled iz Hrvatske. Zagreb: Sveučilište u Zagrebu, Učiteljski fakultet, 371-393.

Kujundžić, Nada. 2019. "Nagrađivane anglofone slikovnice i ilustrirane knjige u hrvatskom prijevodu: slučaj Medalja Caldecott i Kate Greenaway”. In Simljana Narančić Kovač and Ivana Milković (eds.), Prijevodi dječje književnosti: pogled iz Hrvatske. Zagreb: Sveučilište u Zagrebu, Učiteljski fakultet, 291-307.

Kujundžić, Nada and Ivana Milković. 2018. "Disneyjeve višestruke intermedijalne adaptacije proznih djela anglofone književnosti za djecu i mladež u hrvatskim prijevodima". Književna smotra 50/190(4): 121-131.

Kujundžić, Nada. 2018. "Following Her (Father's) Dreams: The Disneyfication of Jacob and Wilhelm Grimm's ‘The Frog King'”. In: Ljubica Matek and Željko Uvanović (eds.), Adaptation: Theory, Criticism and Pedagogy. Selected Papers, Student Projects, and the Dilm Adaptation “Osijek Sweet Osijek”. Aachen: Shaker Verlag, 39-62. 
Kujundžić, Nada. 2018. "Putting the Child Reader First: The Croatian Translation of J.R.R. Tolkien's Father Christmas Letters." [sic] - časopis za književnost, kulturu i književno prevođenje 8(2). https://www.sic-journal.org/ArticleView.aspx?aid=502. https://doi.org/10.15291/SIC/2.8.LC.8

Kujundžić, Nada and Matúš Mišík. 2018. "Powering up the Technodrome: Energy Sustainability in the 1987 Teenage Mutant Ninja Turtles." The Journal of Popular Culture 51(3): 575-594. https://doi.org/10.1111/jpcu.12678

Kos-Lajtman, Andrijana, Sanja Lovrić Kralj, and Nada Kujundžić (eds.). 2018. Stoljeće Priča iz davnine: Zbornik radova. Zagreb: Hrvatska udruga istraživača dječje književnosti. ISBN: 978-953-57604-3-6

Kujundžić, Nada. 2017. "Discipliniranje pripovjedne i čitateljske žudnje u romanu Kći Lotršćaka Marije Jurić Zagorke”. Umjetnost riječi 61(1-2): 67-86.

Kujundžić, Nada. 2016. "The Moral Meets the Marvellous: Grimms' Didactic Fairy Tales". The ESSE Messenger 25(1): 68-80.

Engler, Tihomir, Andrijana Kos-Lajtman, and Nada Kujundžić (eds.). 2016. Stoljeće "Priča iz davnine” Ivane Brlić-Mažuranić: knjiga sažetaka. Zagreb: Hrvatsko društvo za istraživanje dječje književnosti. ISBN: 978-953-57604-2-9

Kujundžić, Nada. 2015. "Prijateljstvo djece i životinja: stvaralaštvo Maje Gluščević". Književnost $i$ dijete 4(3-4): 28-47.

Kujundžić, Nada. 2015. “Slavljenica Alica: 150 godina Zemlje čudesa”. Zarez 411: 19, 30.

Kujundžić, Nada. 2015. “Labora et amare: sto godina Tove Jansson”. Zarez 410: 38-39.

Kujundžić, Nada. 2014. "Moving (Up) in the World: Displacement, Transformation and Identity in Grimms' Fairy Tales". Libri et Liberi 3(2): 219-235. https://doi.org/10.21066/carcl.libri.2014-03(02).0018

Kujundžić, Nada. 2014. "Zle vještice i brižne bake: prikazi starijih ženskih likova u dugometražnim animiranim filmovima studija Walt Disney”. Treća 16(1-2): 49-64.

Kujundžić, Nada. 2013. "Misteriozni Sampo”. Zarez 354: 10-11.

Kujundžić, Nada. 2012. "The Princess with the Quasi-Feminist Agenda: A Glance at Two Disney Films through the Lens of Feminist Criticism”. In Gun-Marie Frånberg, Camilla Hällgren, and Elza Dunkels (eds.), Invisible Girl. Umeå: Umeå University, 263-271.

Kujundžić, Nada. 2012. "Didactic Tales, Formula Tales and Tall Tales in Grimms' Kinderund Hausmärchen". Libri et Liberi 1(2): 179-196. https://doi.org/10.21066/carcl.libri.2012-01(02).0039

Kujundžić, Nada. 2012. "Flying Horses and Magic Carpets. Means of Transport in Select Slavic Fairy Tales for Young Readers". Narodna umjetnost 49(1): 81-94.

Kujundžić, Nada. 2012. "Značaj i funkcija humora u filmskom svijetu Woodyja Allena”. Hrvatski filmski ljetopis 69: 29-46.

Kujundžić, Nada. 2012. “Godina Grimma”. Zarez 347: 42-43. 
Kujundžić, Nada. 2012. “Zašto nema jahačica u bajkama?”. Zarez 328: 10-11.

Kujundžić, Nada. 2011. “'Kakvo je to čudo neviđeno?': utjecaj bajki na Gogoljeve ukrajinske pripovijetke". Croatica et Slavica Iadertina 7(1): 243-277. https://doi.org/10.15291/csi.390

Kujundžić, Nada. 2011. “'Zrcalo, zrcalo, prijatelju moj, / Tko je najljepši u zemlji svoj?’: bajka o Snjeguljici kao intertekst Zagorkinih Plamenih inkvizitora". In Maša Grdešić (ed.), Malleus maleficarum. Zagorka, feminizam, antifeminizam. Radovi sa znanstvenog skupa „Marija Jurić Zagorka - život, djelo, naslijeđe“. Zagreb: Centar za ženske studije, 53-78.

Kujundžić, Nada. 2011. “Teatar zločina: kazališne prakse u ciklusu romana o inspektoru Wallanderu autora Henninga Mankella”. Književna smotra 159(1): 43-55. 